February 2005 - NREL/TP-550-34832

\title{
Evaluation of the Energy Performance and Design Process of the Thermal Test Facility at the National Renewable Energy Laboratory
}

P. Torcellini, S. Pless, B. Griffith, and R. Judkoff

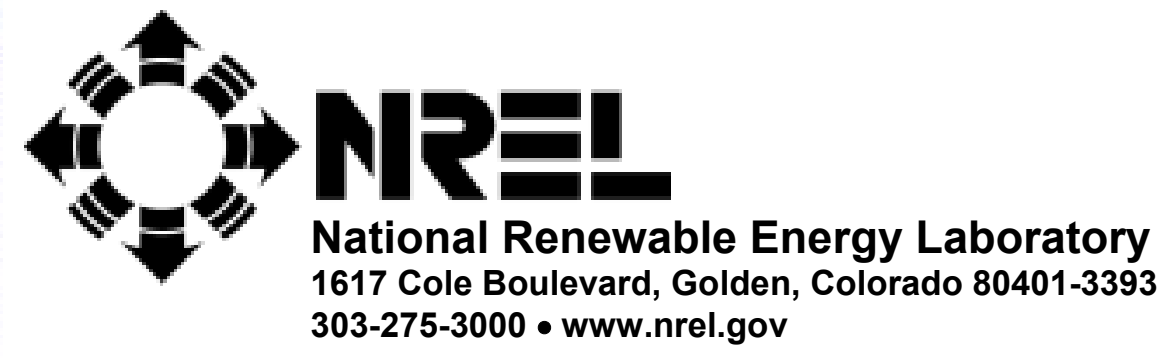

Operated for the U.S. Department of Energy Office of Energy Efficiency and Renewable Energy by Midwest Research Institute • Battelle 


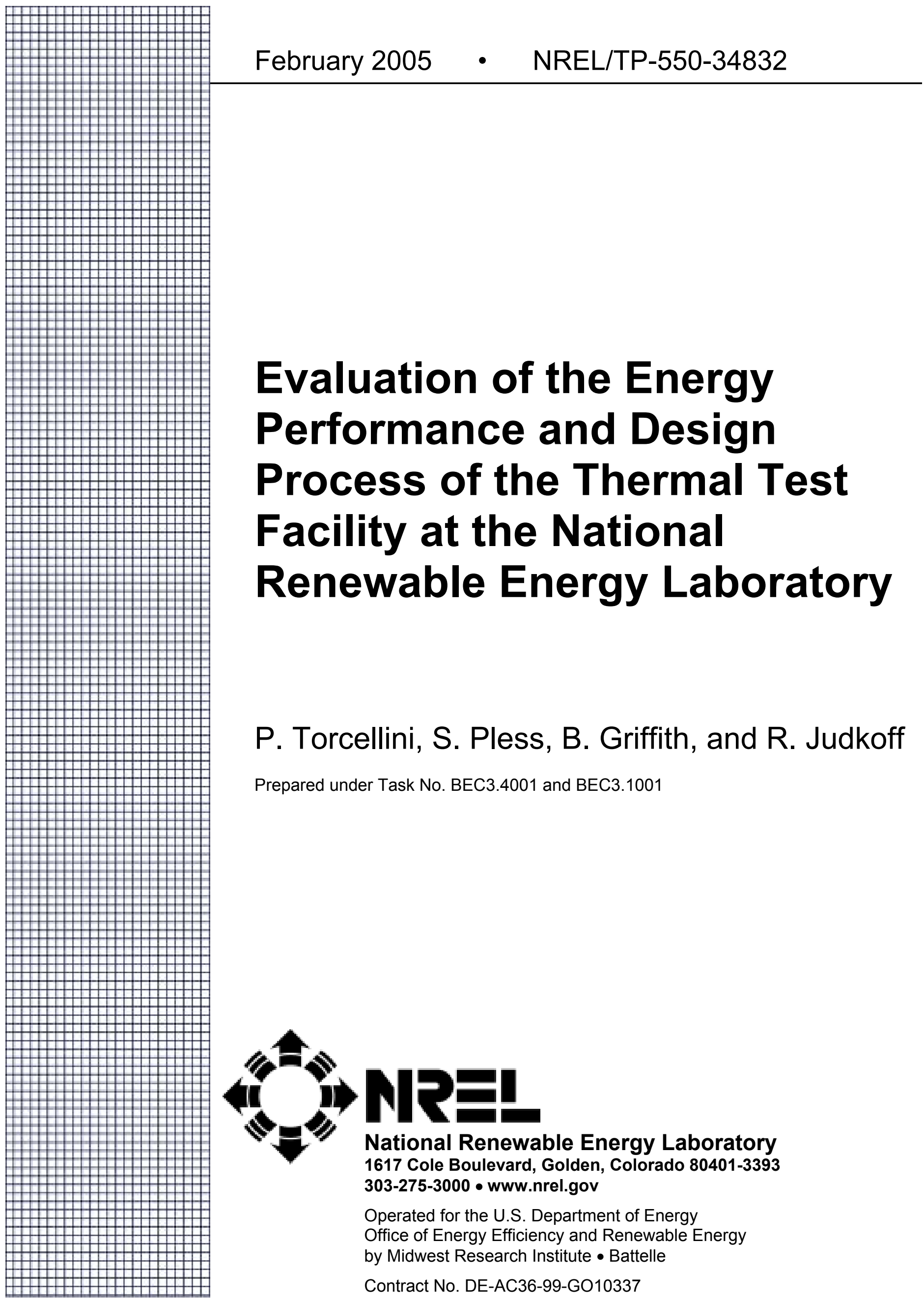




\section{NOTICE}

This report was prepared as an account of work sponsored by an agency of the United States government. Neither the United States government nor any agency thereof, nor any of their employees, makes any warranty, express or implied, or assumes any legal liability or responsibility for the accuracy, completeness, or usefulness of any information, apparatus, product, or process disclosed, or represents that its use would not infringe privately owned rights. Reference herein to any specific commercial product, process, or service by trade name, trademark, manufacturer, or otherwise does not necessarily constitute or imply its endorsement, recommendation, or favoring by the United States government or any agency thereof. The views and opinions of authors expressed herein do not necessarily state or reflect those of the United States government or any agency thereof.

Available electronically at http://www.osti.gov/bridge

Available for a processing fee to U.S. Department of Energy and its contractors, in paper, from:

U.S. Department of Energy

Office of Scientific and Technical Information

P.O. Box 62

Oak Ridge, TN 37831-0062

phone: 865.576 .8401

fax: 865.576 .5728

email: mailto:reports@adonis.osti.gov

Available for sale to the public, in paper, from:

U.S. Department of Commerce

National Technical Information Service

5285 Port Royal Road

Springfield, VA 22161

phone: 800.553 .6847

fax: 703.605.6900

email: orders@ntis.fedworld.gov

online ordering: http://www.ntis.gov/ordering.htm 


\section{Acknowledgments}

This work was made possible by the U.S. Department of Energy's (DOE's) Office of Energy Efficiency and Renewable Energy (EERE). We appreciate the support and guidance of Dru Crawley, Program Manager for EERE's High-Performance Building's initiative, as well as the following people who reviewed this document prior to publication: John Ryan (DOE) and Michael McCabe (Navigant Consulting). In addition, we would like to recognize the following NREL staff members who helped collect information and provide editorial review and analysis support for the effort: Nicholas Long; Kris Lasnik, Lauren Poole, Michael Ketcham, and Sheila Hayter. 


\section{Table of Contents}

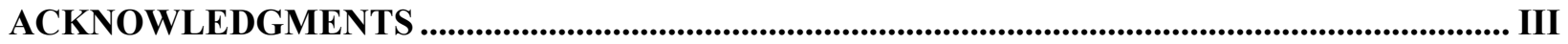

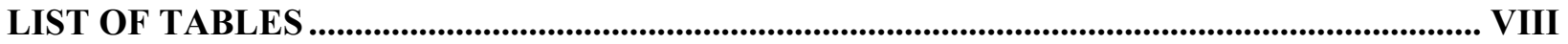

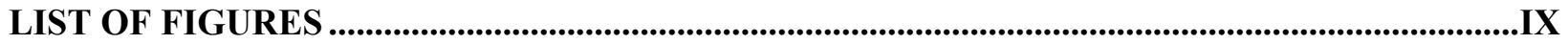

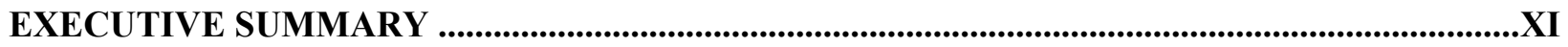

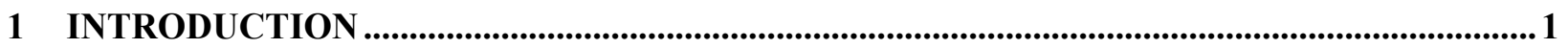

1.1 ENERGY USE IN COMMERCIAL BUILDINGS IN THE UNITED STATES .......................................... 1

1.2 HIGH-PERFORMANCE BUILDINGS RESEARCH OBJECTIVES........................................................ 2

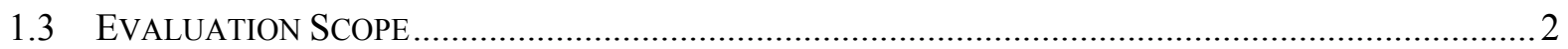

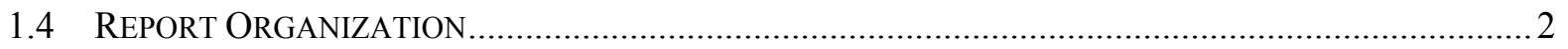

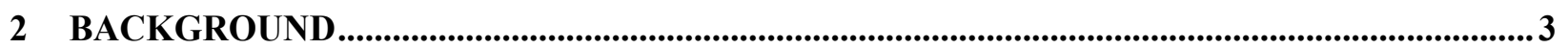

2.1 ENERGY USE COMPARISON TO NATIONAL DATA …................................................................. 3

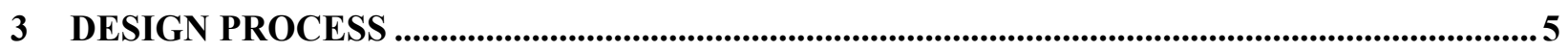

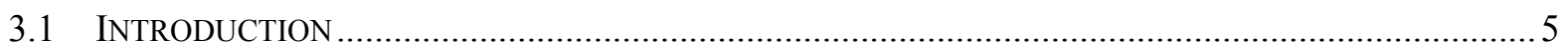

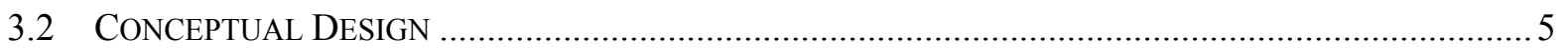

3.3 DESIGN DEVELOPMENT ...................................................................................... 8

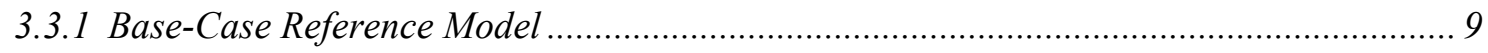

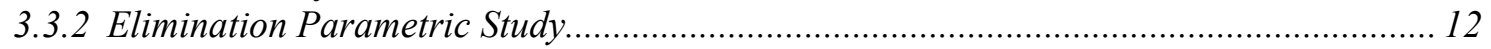

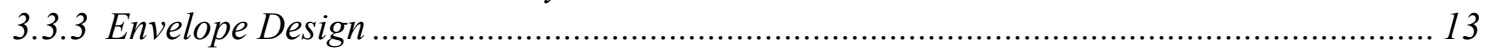

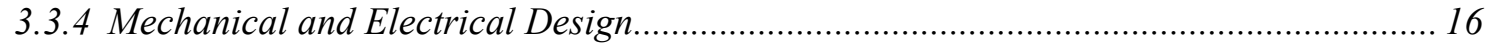

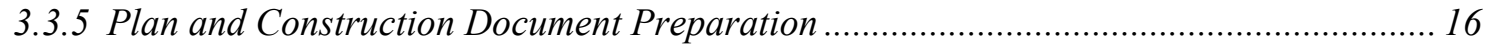

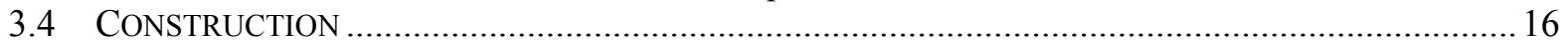

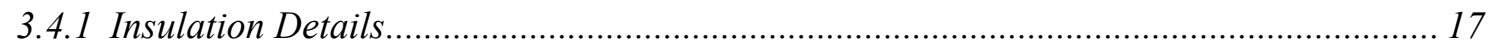

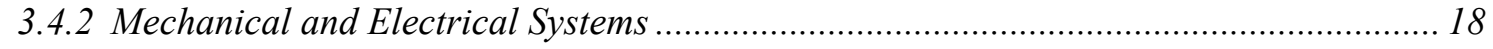

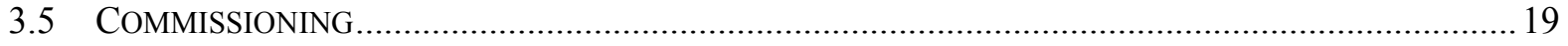

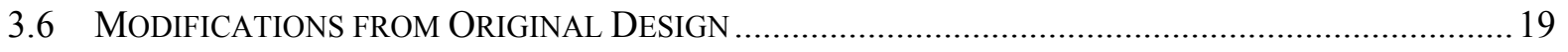

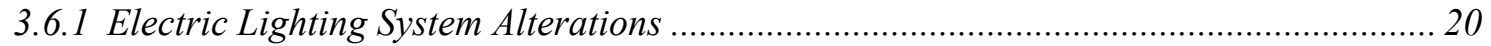

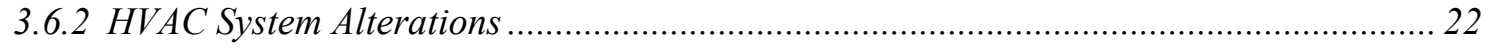

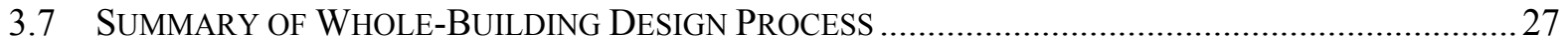

4 TTF BUILDING DESCRIPTION …...................................................................................................29

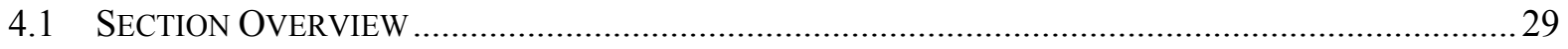

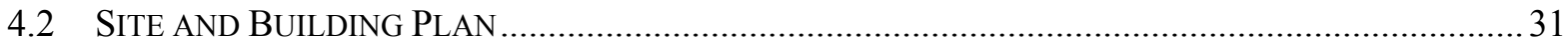

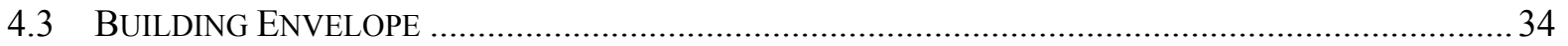

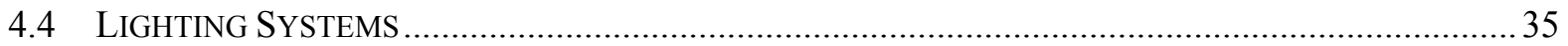

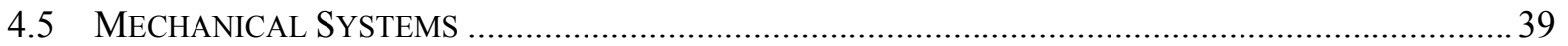

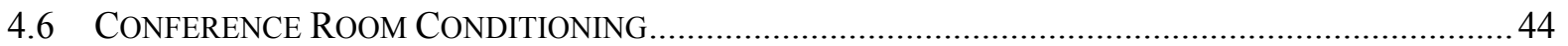

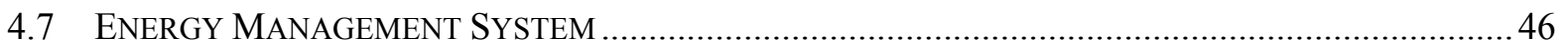

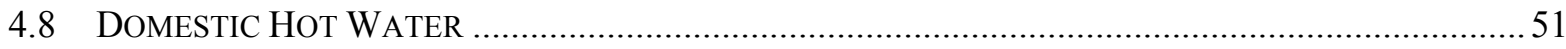

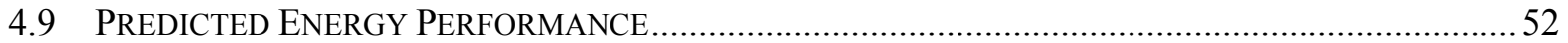




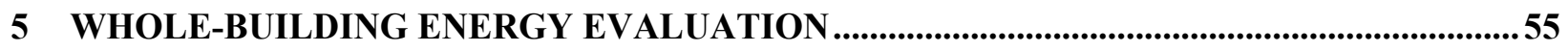

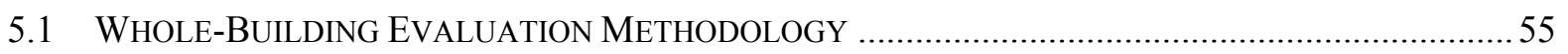

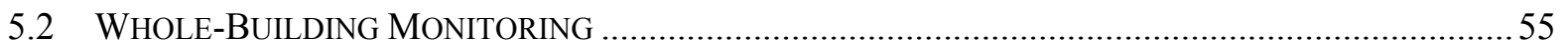

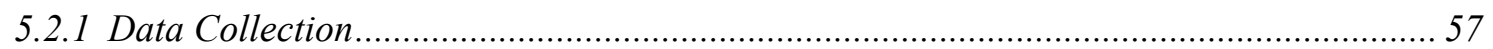

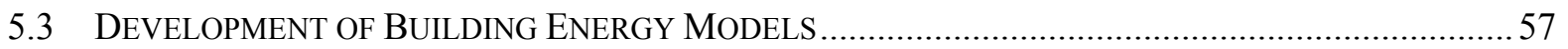

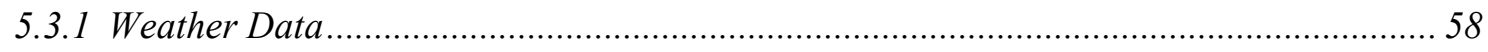

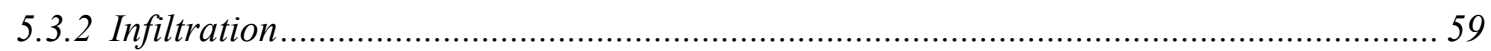

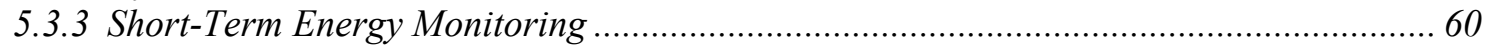

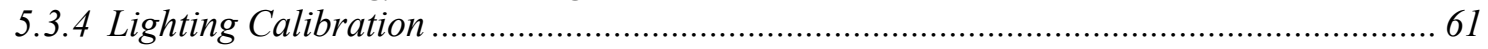

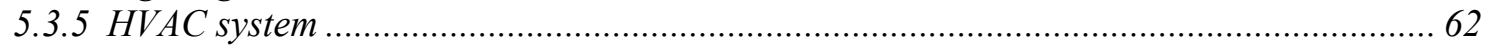

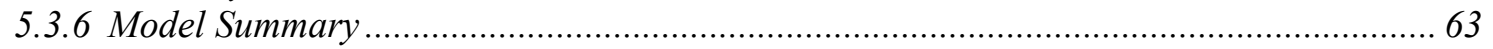

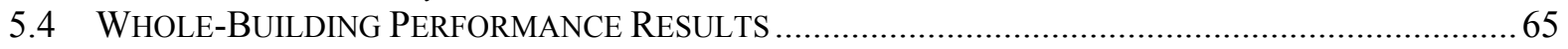

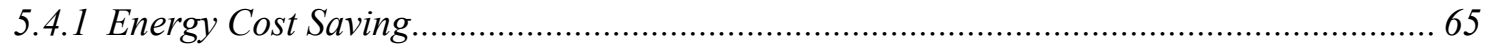

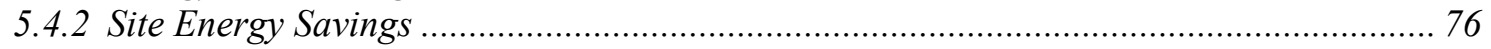

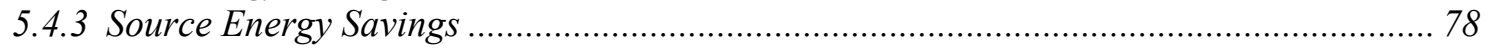

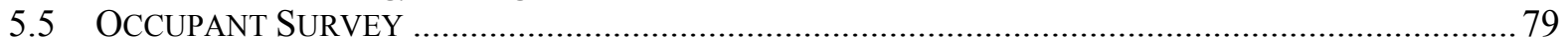

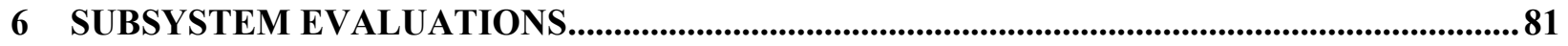

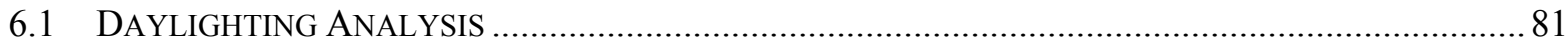

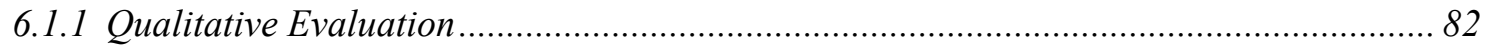

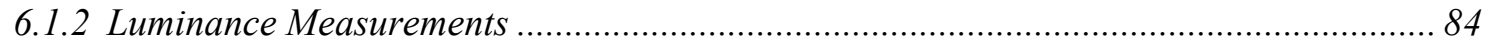

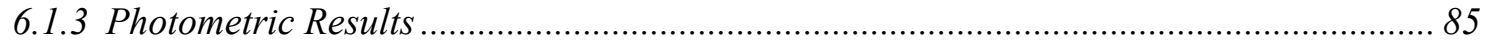

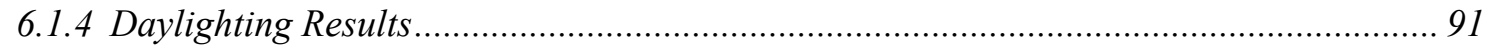

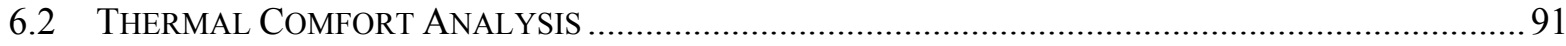

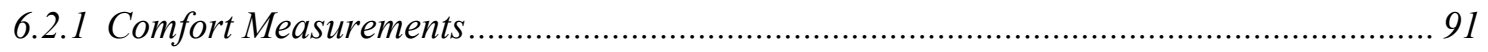

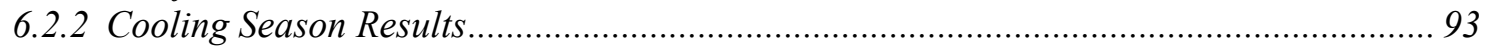

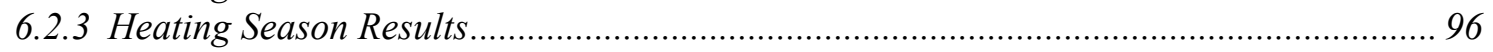

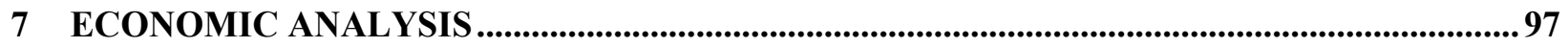

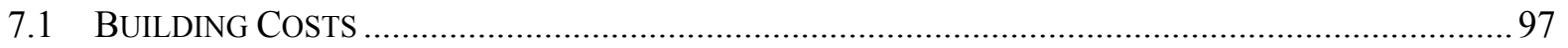

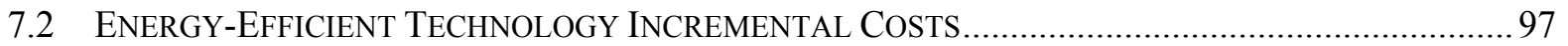

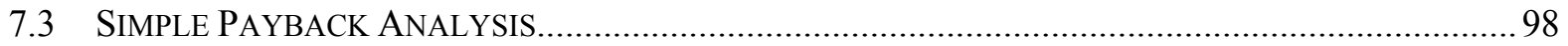

7.4 INCREMENTAL CAPITAL COSTS OF A TYPICAL COMMERCIAL BUILDING ..................................99

7.5 SimPLE PAYBACK ANALYSIS APPLIED TO A TYPICAL COMMERCIAL BUILDING ........................ 100

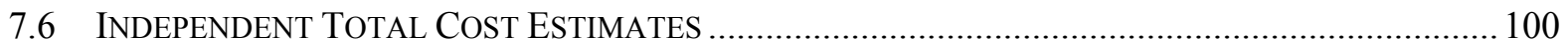

7.6.1 Cost Estimate for Constructing the Existing Building ................................................. 100

7.6.2 Cost Estimate for Constructing the Building in a Commercial Environment................. 100

7.6.3 Cost Estimate for the Building without Windows in a Commercial Environment ........... 101

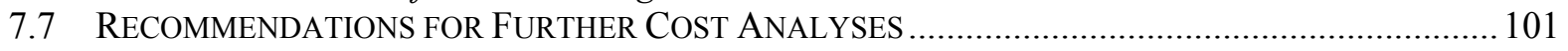

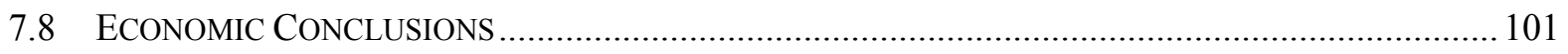

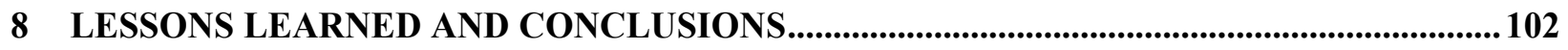

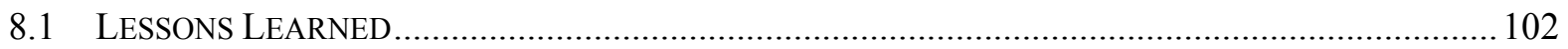

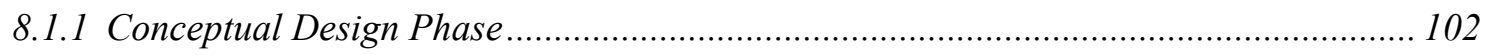

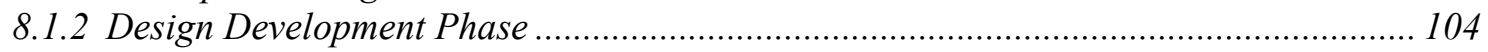

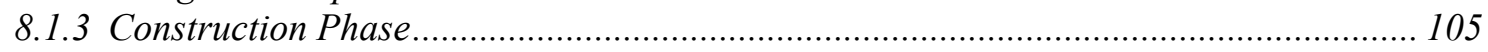

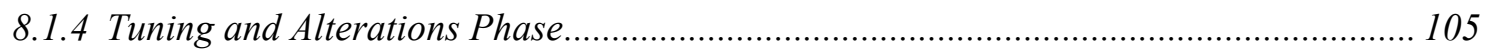

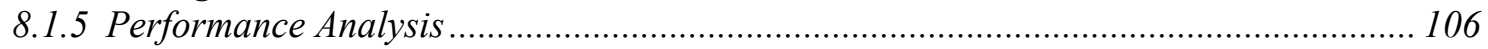

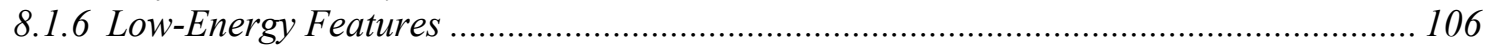

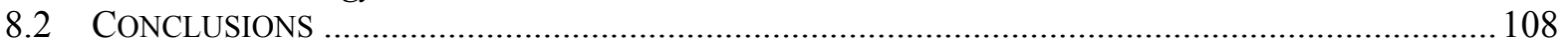




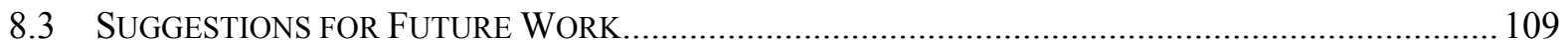

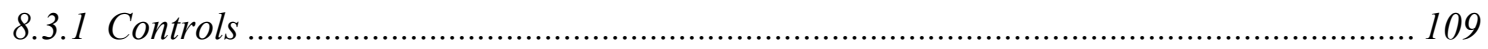

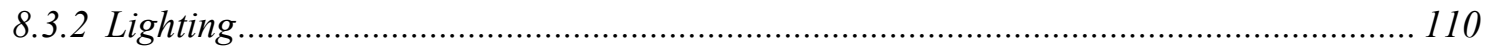

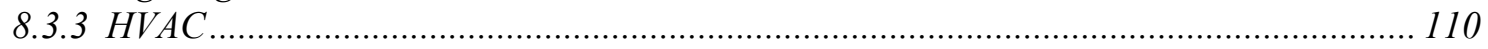

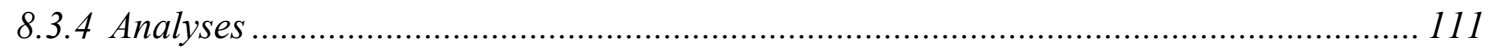

REFERENCES...................................................................................................................................... 112

APPENDIX A. DESIGN TEAM CONTACT LIST ............................................................................114

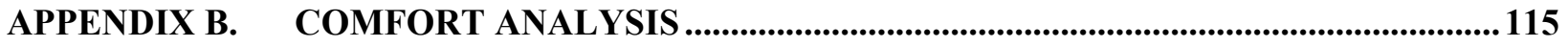

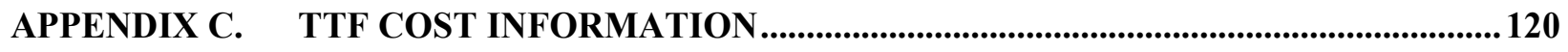

APPENDIX D. CHANGE ORDERS ..................................................................................................... 122

APPENDIX E. COST ESTIMATE COMPARISON BY INDEPENDENT ESTIMATOR........ 123

APPENDIX F. COMMENTS FROM TTF OCCUPANT SURVEY ........................................127 


\section{List of Tables}

Table ES-1

Table 2-1

Table 3-1

Table 3-2

Table 3-3

Table 3-4

Table 3-5

Table 4-1

Table 4-2

Table 4-3

Table 4-4

Table 4-5

Table 4-6

Table 4-7

Table 5-1

Table 5-2

Table 5-3

Table 5-4

Table 5-5

Table 5-6

Table 5-7

Table 5-8

Table 5-9

Table 5-10

Table 5-11

Table 5-12

Table 5-13

Table 6-1

Table 6-2

Table 6-3

Table 6-4

Table 6-5

Table 6-6

Table 6-7

Table 6-8

Table 6-9

Table 6-10

Table 6-11

Table 6-12

Table 7-1

Table 7-2

Table 8-1

Table C-1

Table D-1

Table E-1

Table E-2
Annual Long-Term Performance Metrics xiii

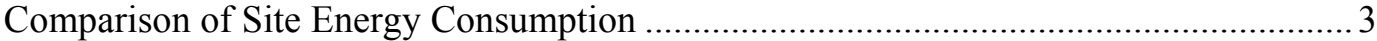

Conceptual Design Space Requirements and Building Technology Criteria ......................6

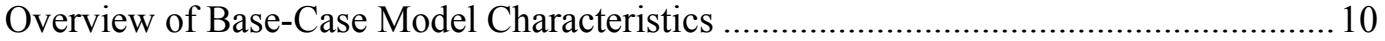

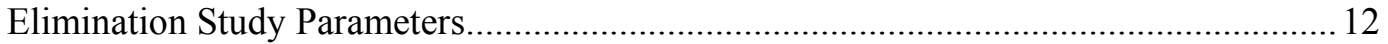

Main Differences between the Original and As-Built Construction Documents............... 17

Nine-Step Process for Designing and Constructing Energy-Efficient Buildings ............. 28

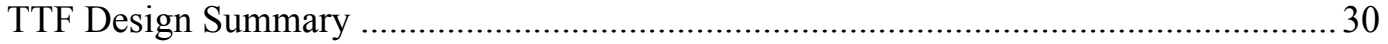

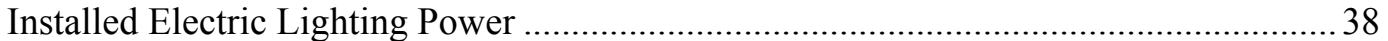

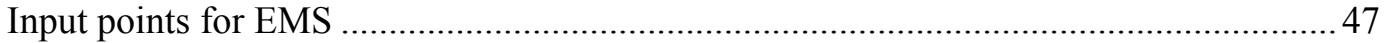

Sensor Types and Associated Accuracy (from specification sheets) ................................49

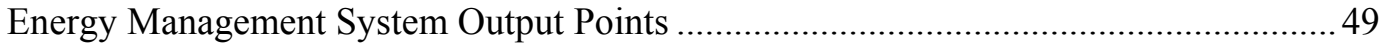

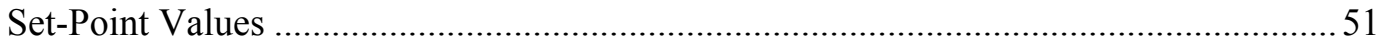

Energy Use and Costs: Final Design Model versus Base-Case Model..............................53

Additional Points Added to EMS for Building Monitoring.............................................56

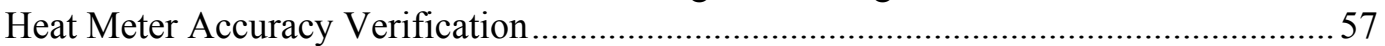

Weather Data Collected for Calibrated Energy Models ..................................................59

BLC Results from STEM Analysis and Modeled Predictions..........................................61

Summary Calibration of the Base-Case and As-Built Energy Models ..............................64

Annual Energy Cost Results from Calibrated Models Using TMY2 Weather Data ........66

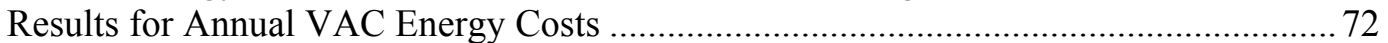

Annual Energy Costs by Type from Calibrated Models Using TMY2 Weather Data ..... 75

Results for Annual Energy Use from Calibrated Models Using TMY2 Weather Data.... 77

U.S. Electricity Generation Emissions.................................................................... 78

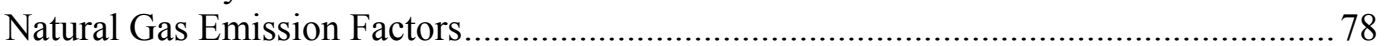

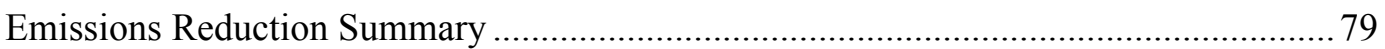

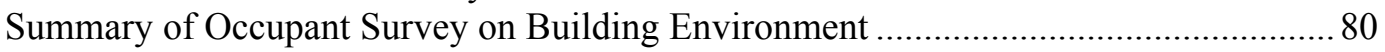

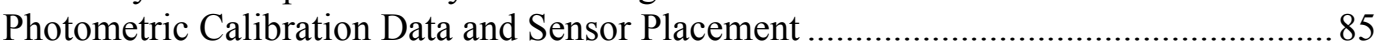

Exterior Horizontal Illumination Sky Condition Correction Factor ............................... 85

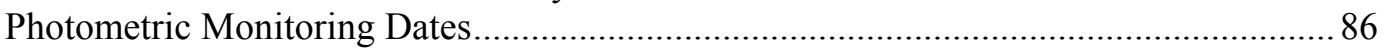

Electrical Lighting System Illumination Values and Sensor Placements .........................8 86

Required Summer Conditions for Comfort Evaluation .................................................. 92

Comfort Analysis Data Types, Relevant Sensors, and Placement Sensors ..................... 92

Comfort Results for Operative Temperature …….......................................................... 93

Asymmetric Radiant Temperature Comfort Results: Summer .........................................93

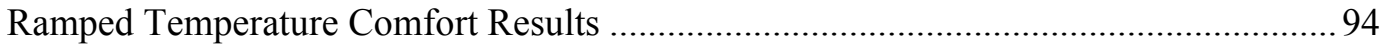

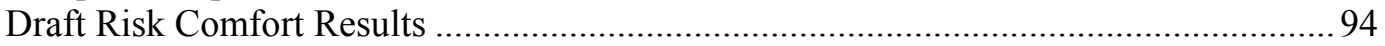

Comfort Results for Vertical Air Temperature Difference ................................................94

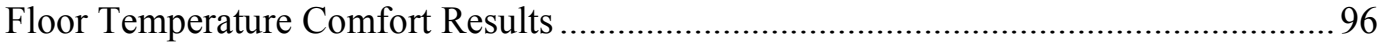

Cost of Energy-Efficient Features .............................................................................. 98

Cost of TTF's Energy-Efficient Features for a Typical Commercial Building ................ 99

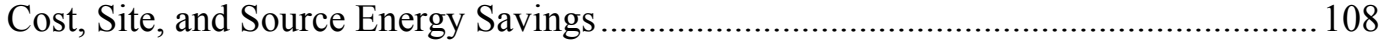

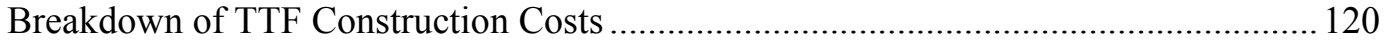

Breakdown of Change Orders during Construction...................................................... 122

Breakdown of Costs for Different Scenarios by an Independent Estimator ................... 123

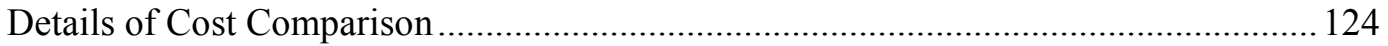




\section{List of Figures}

Figure ES-1 Annual site energy costs of TTF compared to base case for a typical meteorological year (calibrated simulation) ...........................................................................................

Figure 2-1 Site energy use and cost intensity by building type for commercial buildings in the

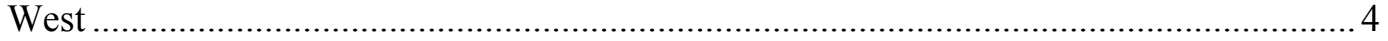

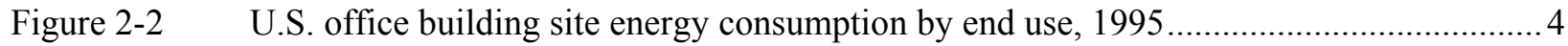

Figure 3-1

Figure 3-2

Figure 3-3

Figure 3-4

Figure 3-5

Figure 3-6

Figure 3-7

Figure 3-8

Figure 3-9

Figure 3-10

Figure 3-11

Figure 3-12

Figure 3-13

Timeline for TTF design, construction, and monitoring...

Early conceptual schematic for integrating low-energy daylighting, passive solar, and

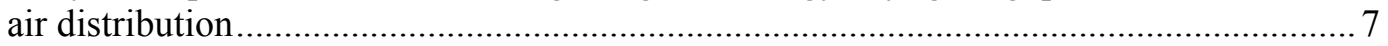

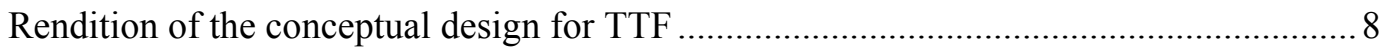

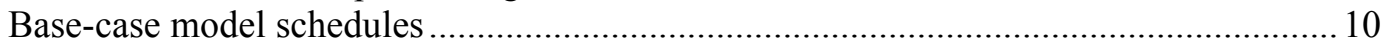

Base-case energy model geometry ............................................................................. 11

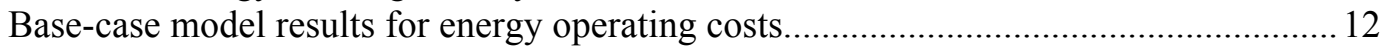

Elimination parametric results for energy cost ....................................................... 13

Overhang ratios for Boulder, Colorado, used for the starting point for the TTF

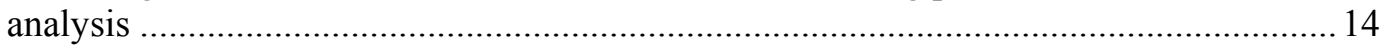

Impact of clerestory window height on annual energy cost........................................... 15

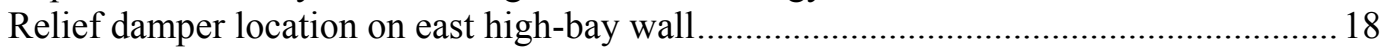

Mid-bay clerestory daylight at low-sun angles before installation of blinds .................... 21

Mid-bay clerestory daylight at low-sun angles after installation of blinds ....................... 22

Direct evaporative cooler plumb schematic showing problem during construction

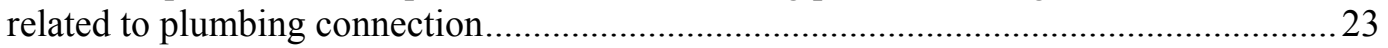

Figure 3-14 Supply fan speed controller input versus current draw .............................................25

Figure 3-15 Ceiling fan variable-speed controller output versus current draw .................................26

Figure 3-16 Ventilation fan variable-speed controller output versus current draw .............................26

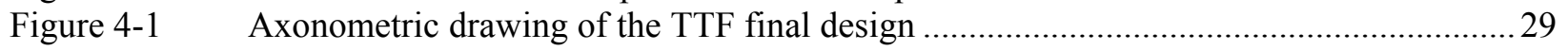

Figure 4-2 As-built floor plan for the Thermal Test Facility...................................................... 31

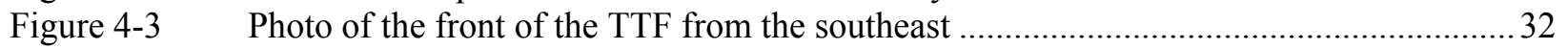

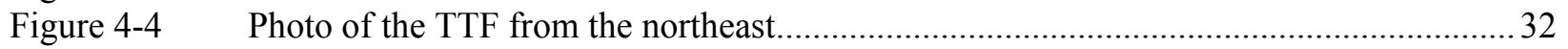

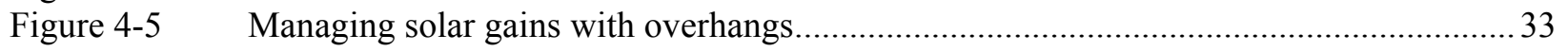

Figure 4-6 Overhang ratios for clerestories (a) and view glass (b) .............................................. 34

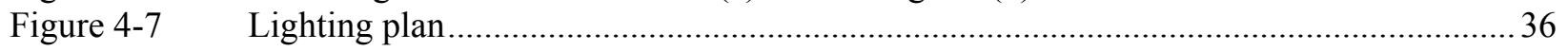

Figure 4-8 Sensor used by the EMS to control electric lighting based on availability of natural

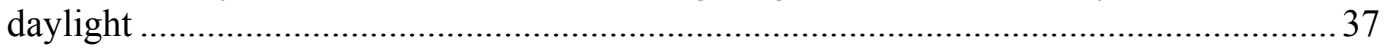

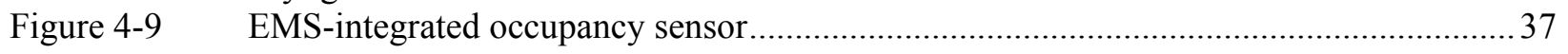

Figure 4-10 Efficient electric lighting luminaires include T-8 (left photo) and CFL can fixtures

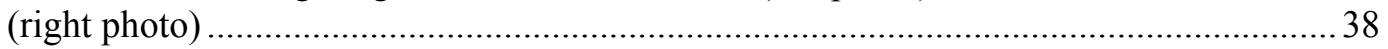

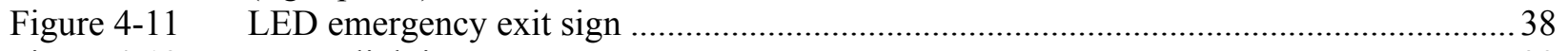

Figure 4-12 Egress lighting ................................................................................................. 39

Figure 4-13 Schematics of main building air systems (a) ventilation air system, (b) heating and

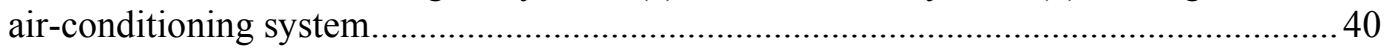

Figure 4-14 Main air handler with indirect/direct evaporative cooling ............................................ 41

Figure 4-15 Evaporative cooler operation on a cooling design day .................................................42

Figure 4-16 Parallel terminal boxes allow for heating without operating main air-handler................. 43

Figure 4-17 Air-to-air heat exchanger removes air from restrooms and kitchen and provides fresh

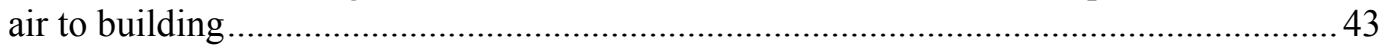

Figure 4-18 Ceiling fans destratify the air without using the main air-handler................................ 44

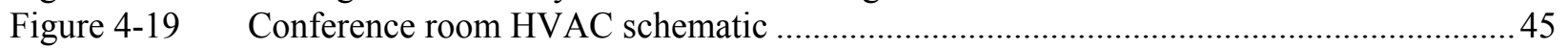

Figure 4-20 Conference room rooftop packaged system (located indoors)....................................... 45 
Figure 4-21

Figure 4-22

Figure 4-23

Figure 4-24

Figure 5-1

Figure 5-2

Figure 5-3

Figure 5-4

Figure 5-5

Figure 5-6

Figure 5-7

Figure 5-8

Figure 5-9

Figure 5-10

Figure 5-11

Figure 5-12

Figure 5-13

Figure 5-14

Figure 5-15

Figure 5-16

Figure 6-1

Figure 6-2

Figure 6-3

Figure 6-4

Figure 6-5

Figure 6-6

Figure 6-7

Figure 6-8

Figure 6-9

Figure 6-10

Figure 6-11

Figure 6-12

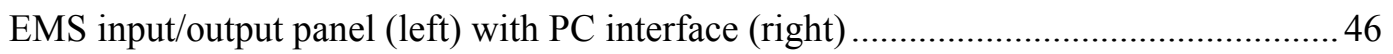

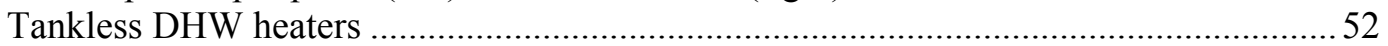

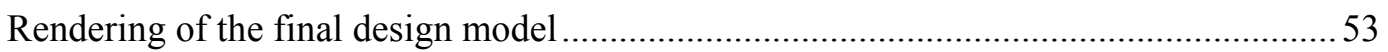

Summary of results for energy costs: final design model versus base-case model............54

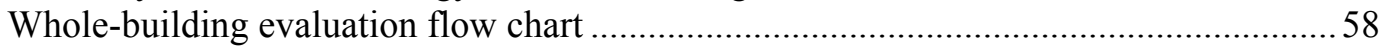

Results from tracer gas measurement of infiltration rate ..................................................5 59

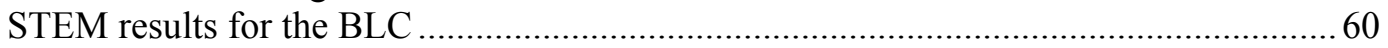

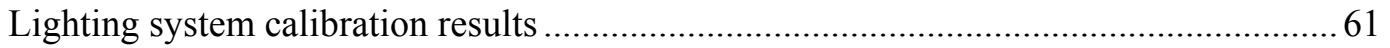

Comparison of calibrated model versus actual measurements for building heating

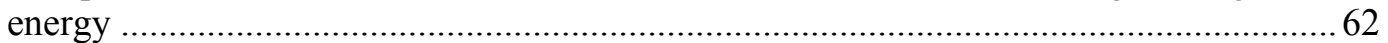

Results for HVAC system electricity energy use: calibrated model versus

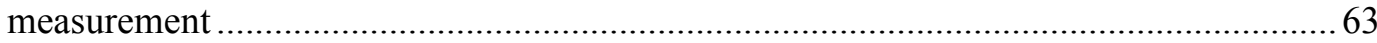

Pie charts of annual energy costs (excluding plug loads) from (a) the calibrated base-

case model and (b) the calibrated as-built model.

Graph of energy costs and savings for lighting by month based on a typical operating year.....

Electric lighting power consumption on typical clear day and cloudy day ......................69

Heating loads on a cloudy day compared with heating loads on a sunny day ..................70

Infrared thermal images showing heat loss through window frames................................ 71

Infrared thermal images showing heat loss at the foundation...................................... 71

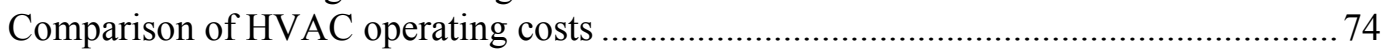

Daily energy use for heating, cooling, pumps, and fans for the TTF compared with

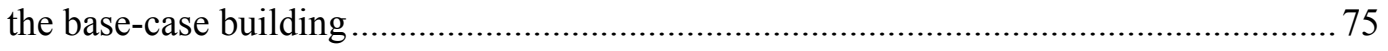

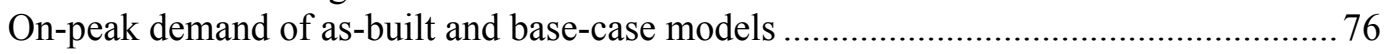

Average daily energy use from the calibrated base-case model and the calibrated as-

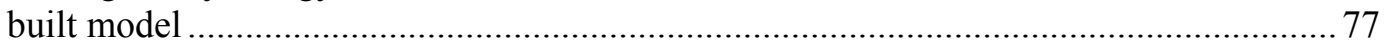

Perimeter office on sunny day with only daylighting (glazing is to the left of the

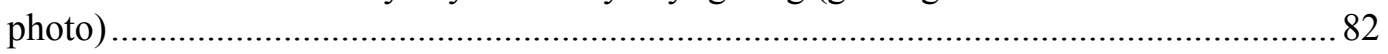

Interior office cubicle when illuminated by daylight only (south is to the right) ............. 83

Mid-bay laboratory space illuminated by daylight (west end of building - photo taken

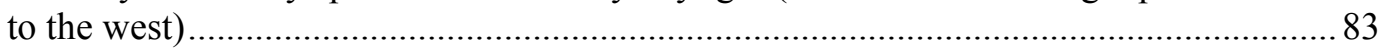

High-bay laboratory spaces illuminated by daylight (note direct gain stripe) .................. 84

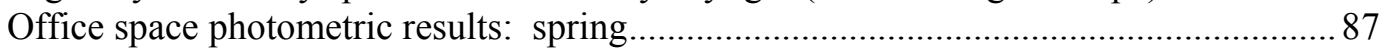

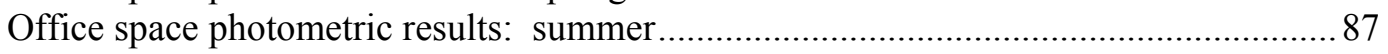

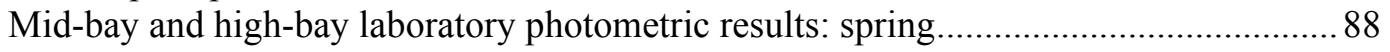

Mid-bay and high-bay laboratory photometric results: summer.................................... 89

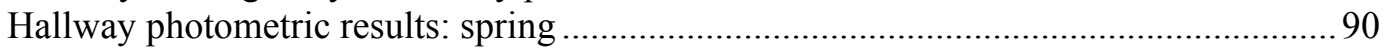

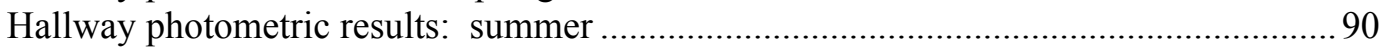

High-bay insulated roll-up door thermographic results ................................................. 95

Comfort results for vertical temperatures during heating season..................................96 


\section{Executive Summary}

\section{Introduction}

The National Renewable Energy Laboratory (NREL) built the Thermal Test Facility (TTF) in 1996 to serve as a research facility for its Center for Buildings and Thermal Systems. The new facility offered NREL the opportunity to refine and test the integrated building design process it was researching at the time. The integrated design process suggested that energy consumption could be significantly reduced by considering how building technologies work together most efficiently. For example, electrical loads could be significantly reduced by meeting electrical lighting needs with natural light (daylighting), which would also reduce the size of the heating and cooling ductwork systems needed for the building. Computer-simulated design, which was not being used by industry at the time, formed the basis of the design process. Computer simulation allows design concepts to be tested before being incorporated into the building. Energy performance determined with the computer-simulated design could then be compared with the constructed building's actual energy performance. The energy performance design goal for the TTF was to reduce the energy costs to light, heat, cool, and ventilate by $70 \%$.

NREL designed the TTF to take advantage of the sunshine available in Colorado throughout most of the year. Clerestory windows were incorporated to maximize the use of natural light and to minimize summer cooling loads. A rigid exterior finish was used to minimize envelope heat transfer. A directindirect evaporative air-conditioning system was designed to meet the building's normal cooling loads, while keeping humidity levels within the comfort range without the use of conventional cooling coils. Air-to-air heat exchangers introduced fresh air into the building and reduced heating and cooling needs by transferring energy between exhaust air leaving the building and fresh air entering the building. An energy management system monitored and controlled internal conditions (temperature, humidity, air pressure, duct pressure, light levels, and carbon dioxide levels) of the building to determine the most efficient method for maintaining occupant comfort.

Evaluation of the building after construction helped NREL to refine the low-energy design process. It showed that an integrated design could be easily adapted for office, retail, or warehouse space. This report provides an overview of the design process used for the TTF and the building performance results based on 2 years of monitoring and energy simulations. The report details how energy savings were determined and provides general recommendations that the building community can use to improve the process of creating energy-efficient buildings.

\section{Approach}

NREL monitored the building to determine its actual energy performance. Data captured every 15 minutes included major end-loads such as lighting, plug loads, and heating, ventilation, and airconditioning.

Following the monitoring period, NREL developed a computer model of the actual building. NREL used weather data to simulate the weather during the monitoring period. Actual occupancy profiles and plug loads were also used. NREL calibrated the model against measured lighting data and HVAC energy consumption. This model was used to determine the average energy performance with typical meteorological year weather data. NREL also reevaluated the base-case model using the same occupancy patterns, weather data, and temperature set points to determine a percent energy savings. 


\section{Results}

The TTF cost $63 \%$ less per year to heat, ventilate, cool, and light than a code-compliant, base-case building. The base-case building discussed here complied with the requirements of the Code of Federal Regulations 10 CFR 435 (DOE 1995) based on the American Society of Heating, Refrigerating, and AirConditioning Engineers (ASHRAE) Standard 90.1-1989 (ASHRAE 1989), yet with more stringent lighting power density requirements.

Because receptacle loads were not part of the original criteria for the analysis, they are not reflected in the percent savings above. However, when plug loads are included $\left(6.9 \mathrm{kBtu} / \mathrm{ft}^{2} \cdot \mathrm{yr}\right.$ or $\left.78 \mathrm{MJ} / \mathrm{m}^{2} \cdot \mathrm{yr}\right)$ in the asbuilt model, energy use intensity is $28.9 \mathrm{kBtu} / \mathrm{ft}^{2} \cdot \mathrm{yr}\left(328 \mathrm{MJ} / \mathrm{m}^{2} \cdot \mathrm{yr}\right)$ compared with a base-case intensity of $49.0 \mathrm{kBtu} / \mathrm{ft}^{2} \cdot \mathrm{yr}\left(558 \mathrm{MJ} / \mathrm{m}^{2} \cdot \mathrm{yr}\right)$. The analysis demonstrated that with strong design goals, substantial energy savings could be achieved in commercial buildings. Annual energy costs of the reference model and the TTF model are shown in Figure ES-1. If plug loads are not included, the energy cost saving is $63 \%$ to condition and light the TTF. If typical office loads are included, the energy cost saving is $52 \%$. Summary metrics are presented in Table ES-1.

Reducing energy costs was an overall goal for the building design; therefore, an energy cost metric approach is used throughout this document to report performance. In addition to determining the energy cost saving that resulted from the TTF's advanced energy design, the process of monitoring and evaluating actual building energy performance led researchers to identify and correct design and operation issues.

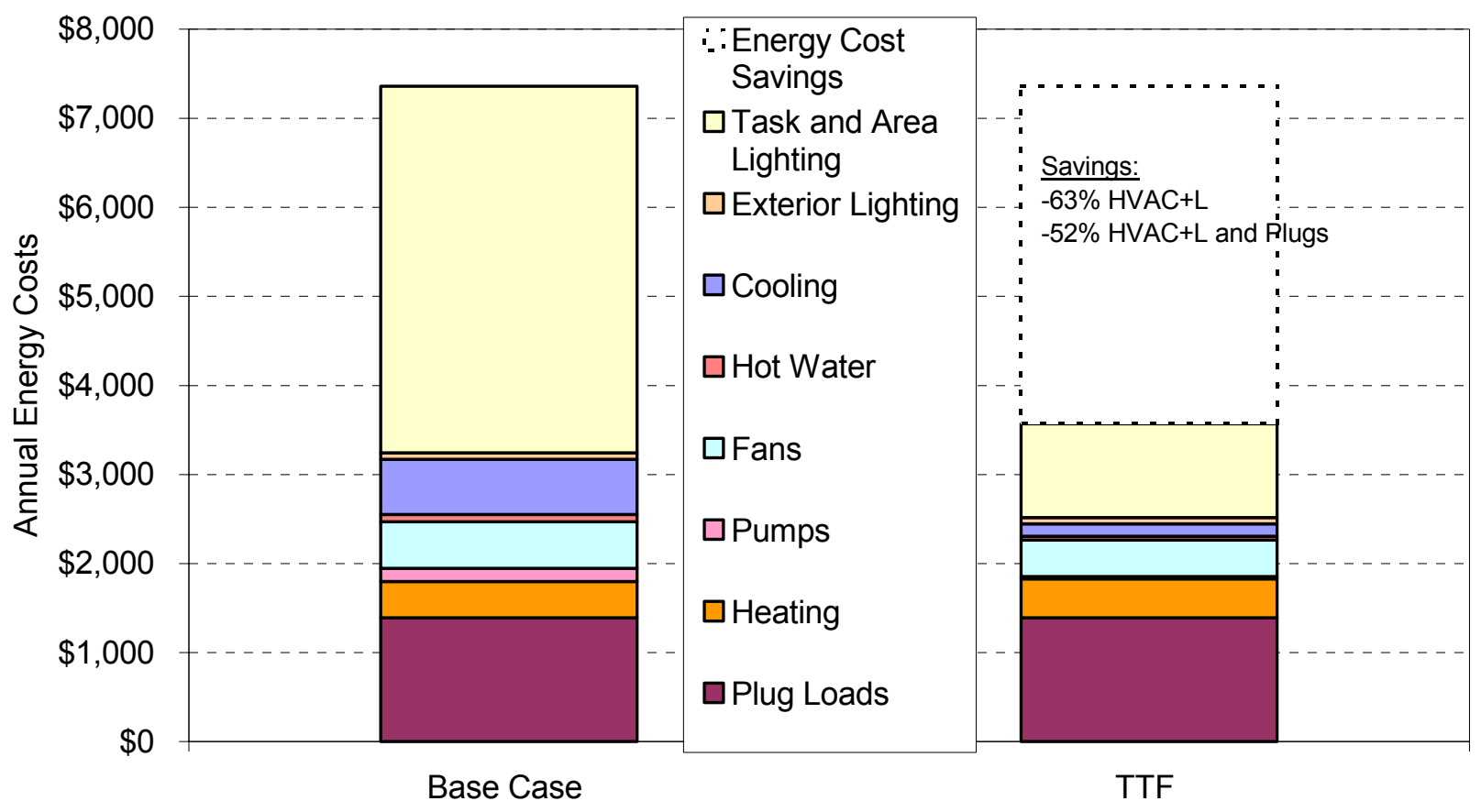

Figure ES-1 Annual site energy costs of TTF compared to base case for a typical meteorological year (calibrated simulation) 
Table ES-1 Annual Long-Term Performance Metrics

\begin{tabular}{|l|c|}
\hline \multicolumn{2}{|c|}{ Energy Performance Metrics } \\
\hline $\begin{array}{l}\text { Site Purchased Energy Cost Intensity } \\
\text { (including plug loads) }\end{array}$ & $\begin{array}{c}\$ 0.35 / \mathrm{ft}^{2} \\
\left(\$ 3.88 / \mathrm{m}^{2}\right)\end{array}$ \\
\hline $\begin{array}{l}\text { Total Site Energy Use Intensity, TTF } \\
\text { model }\end{array}$ & $\begin{array}{l}28.9 \mathrm{kBtu} / \mathrm{ft}^{2} \\
\left(328 \mathrm{MJ} / \mathrm{m}^{2}\right)\end{array}$ \\
\hline $\begin{array}{l}\text { Percent HVAC+L Energy Cost } \\
\text { Savings Compared to Base Case }\end{array}$ & $63 \%$ \\
\hline $\begin{array}{l}\text { Percent Total Energy Cost Savings } \\
\text { Compared to Base Case }\end{array}$ & $52 \%$ \\
\hline $\begin{array}{l}\text { Percent Site Energy Use Savings } \\
\text { Compared to Base Case }\end{array}$ & $41 \%$ \\
\hline Source Energy Use Intensity & $\begin{array}{l}66.2 \mathrm{kBtu} / \mathrm{ft}^{2} \\
\left(752 \mathrm{MJ} / \mathrm{m}^{2}\right)\end{array}$ \\
\hline
\end{tabular}

The TTF is a $10,000-\mathrm{ft}^{2}\left(929-\mathrm{m}^{2}\right)$ mixed office/light laboratory building that demonstrates how a number of efficient technologies and a whole-building design approach can be applied to create low-energy buildings in a number of commercial building sectors. Conducting this study led to the following general conclusions:

- It is possible to build a small commercial building that uses much less energy than a code-compliant building, maintains occupant satisfaction, and remains within the constraints of a fixed budget.

- Case studies of real buildings identify important issues to address when designing, constructing, and operating a low-energy building.

- An integrated, whole-building design approach facilitates the design and construction of low-energy buildings.

- The design team should be committed to a low-energy building by setting quantifiable energy performance goals.

- The design team should consider the consequences of programmatic requirements on energy use and use energy models to guide design decisions.

- It is important to maintain adequate quality control during construction to ensure that energy features are included as designed.

- For the TTF, incorporating daylighting to reduce electric lighting energy loads provides the most significant energy savings.

- In a dry climate, indirect/direct evaporative cooling can provide sufficient cooling capacity with less energy use than refrigerant-based cooling systems.

- Occupants can be distracted by the operation of stepped electrical lighting controls.

- Allowing direct-beam solar radiation to enter through fenestration can provide sufficient space lighting, but it can also cause glare problems. 


\section{Introduction}

The Thermal Test Facility (TTF) was completed in 1996 to function as both a research laboratory and an office building. Because the building was constructed at the National Renewable Energy Laboratory (NREL) in Golden, Colorado, the project provided NREL the opportunity to participate in the design process and use the building to test its high-performance, whole-building approach to design.

The high-performance design of the TTF incorporates many passive solar and energy-efficient features that minimize building electrical loads while maintaining occupant comfort. Examples include daylighting and direct-indirect evaporative cooling. Research conducted inside the TTF includes studies of advanced cooling systems, ventilation systems, ventilation pre-heat, and active solar systems. In addition to housing research facilities, the building was designed as a research model that provides data that can be applied to buildings designed in the future.

This report is part of a series of six case studies to develop, document, analyze, and evaluate the processes by which highly energy-efficient buildings can be reliably produced. In this project, NREL was able to develop and test the low-energy design process. This process covers predesign through postoccupancy, relies heavily on building energy simulation, and also includes other important qualitative and quantitative features such as design charrettes with all members of the design team, and the establishment of energy goals through the use of computer modeling. It would not have been possible for NREL to conduct this research without close collaboration with real building design and construction projects. It is not practical to use classical controlled repeatable experimental techniques for objects as large and complex as commercial buildings, and for design and construction processes that of necessity involve so many different players over an extended period.

This report provides documentation for the design process used to construct the TTF as well as an analysis of its energy performance. Objectives are to:

- Evaluate and document the low-energy design of the TTF.

- Evaluate the energy performance of the TTF.

A number of publications have featured the TTF, including research reports (Hayter et al. 1998, Hayter et al. 2000) and magazines (Miller 1998, Hayter et al. 1999, Torcellini et al. 2004). The TTF also received an ASHRAE Technology Award in 1999, a Jefferson County Design Excellence Award in 1997, and an Energy User News Efficient Building Award in 1997.

\subsection{Energy Use in Commercial Buildings in the United States}

The operation of commercial buildings accounts for approximately $18 \%$ of the primary energy consumption in the United States. According to the U.S. Department of Energy (DOE 2003), the total for all residential and commercial buildings is more than one-third of the primary energy consumption and $70 \%$ of the electricity consumption. Energy consumption can be expressed as the amount of energy consumed within the building (site energy) or as the sum of the energy directly consumed at the site and the energy consumed in the production and delivery of energy products (primary or source energy). Documenting primary energy consumption is important when emissions from energy sources are of concern. Primary energy used in residential and commercial buildings in the United States results in 35\% of U.S. and $9 \%$ of global carbon dioxide $\left(\mathrm{CO}_{2}\right)$ emissions. Electricity consumption in the commercial building sector has doubled in the last 18 years, and it is expected to increase by another $25 \%$ by 2030 if current growth rates continue (EIA 1998). Reducing site energy consumption in commercial buildings through energy-efficient and renewable building technologies would significantly reduce primary energy consumption in the United States (EIA 1998). Site energy is also a concern for the building owner or those responsible for paying the utility bills. 


\subsection{High-Performance Buildings Research Objectives}

NREL conducts research for DOE's High-Performance Buildings initiative (HPBi). HPBi evaluates commercial buildings from a whole-building design approach to better understand the integration issues and opportunities during building design and operation. By evaluating buildings in this manner, substantial gains in energy reduction are achieved in commercial buildings while improving other attributes, such as occupant satisfaction. The HPBi's long-term goal is to reduce energy use in commercial buildings by $50 \%$ when compared to applicable energy codes. Documenting the performance of research-level buildings provides evidence that buildings using 50\% less energy can be built and operated and helps to transform the marketplace. The objectives of HPBi research are to:

- Develop high-performance building prototypes through better design and construction processes

- Ensure high-performance after construction through better operation processes

- Provide the tools needed to replicate the processes and design strategies for creating highperformance buildings

- Research new technologies for high-performance buildings

- Develop standardized metrics and procedures for measuring building energy performance

- Measure and document building performance in high-profile examples.

\subsection{Evaluation Scope}

The evaluation scope concentrated on the design process, the energy features of the building, the energy performance analysis (without the variable internal loads), and the evaluation of some building systems.

From the beginning of the process, NREL understood that the function of the building would be unique and potentially highly variable. However, the construction is typical of many $10,000-\mathrm{ft}^{2}\left(929-\mathrm{m}^{2}\right)$ buildings. Actual data from the building were used to calibrate a computer simulation for the analysis. Results from the calibrated model, combined with typical internal loads, are presented here to broaden the potential value of the information.

This report is mostly historical because the TTF project began in 1993 and performance monitoring concluded in 1999. Writing the report in the historical context offered an opportunity to pull out lessons learned and take a somewhat removed and critical view of the project.

\subsection{Report Organization}

This report describes the design process (Chapter 3) and energy-related features of the building (Chapter 4). It also provides an analysis of the building's energy performance (Chapter 5), an evaluation of subcomponents of the building (Chapter 6), an economic analysis of the project (Chapter 7), and concludes with recommendations and lessons learned from the project evaluation. 


\section{Background}

On October 3, 1996, NREL opened the TTF as one of several research facilities located at NREL. It is situated between the Alternative Fuels User Facility to the west and the Outdoor Test Facility to the east, with South Table Mountain rising to the north behind the building. The building axis runs east to west, with the main facade facing almost directly south. The site longitude is $105.2^{\circ} \mathrm{W}$ and the site latitude is $39.74^{\circ} \mathrm{N}$ in time zone GMT-7, with a sited elevation of 5,900 ft $(1,845 \mathrm{~m})$. Weather is typical of Colorado's sunny Front Range, with 6,083 heating degree-days (Base $65^{\circ} \mathrm{F}\left[18^{\circ} \mathrm{C}\right]$ ) and 567 cooling degree-days (Base $65^{\circ} \mathrm{F}\left[18^{\circ} \mathrm{C}\right]$ ).

\subsection{Energy Use Comparison to National Data}

To fully evaluate the TTF's energy performance, it was important to have energy use comparison data. NREL began its analysis by examining data collected on thousands of U.S. commercial buildings by the Energy Information Administration (EIA). In 1999, EIA conducted the Commercial Buildings Energy Consumption Survey (CBECS), a national survey that collected information on thousands of building types in the United States, including building characteristics, energy consumption, and energy expenditures for all types of commercial buildings.

This section presents data on energy use and cost levels of typical buildings. Table 2-1 lists the energy use intensities of various building categories from the CBECS database. Although the TTF does not directly fit into any of these categories, these data are useful to determine the energy performance range of typical buildings.

Table 2-1 Comparison of Site Energy Consumption

\begin{tabular}{|c|c|c|}
\hline \multirow{2}{*}{ CBECS Building Category } & \multicolumn{2}{|c|}{ Site Energy Intensity } \\
\hline & kBtu/ft ${ }^{2}$ & $\left(M J / m^{2}\right)$ \\
\hline All Office Buildings & 90.5 & 1,028 \\
\hline All Office Buildings in the West & 84.3 & 957 \\
\hline All Commercial Buildings in the West Constructed between 1990-1999 & 97.3 & 1,105 \\
\hline All Office Buildings from $1,000-10,000 \mathrm{ft}^{2}$ & 74.7 & 848 \\
\hline All Office Buildings from $10,000-100,000 \mathrm{ft}^{2}$ & 83.1 & 944 \\
\hline
\end{tabular}

Figure 2-1 shows the energy use and cost intensity over the range of building types for commercial buildings in the West. Figure 2-2 shows the energy end-use distribution in typical office buildings. Note that lighting is the largest end use in office buildings, with space heating and office equipment the nextlargest end uses. 


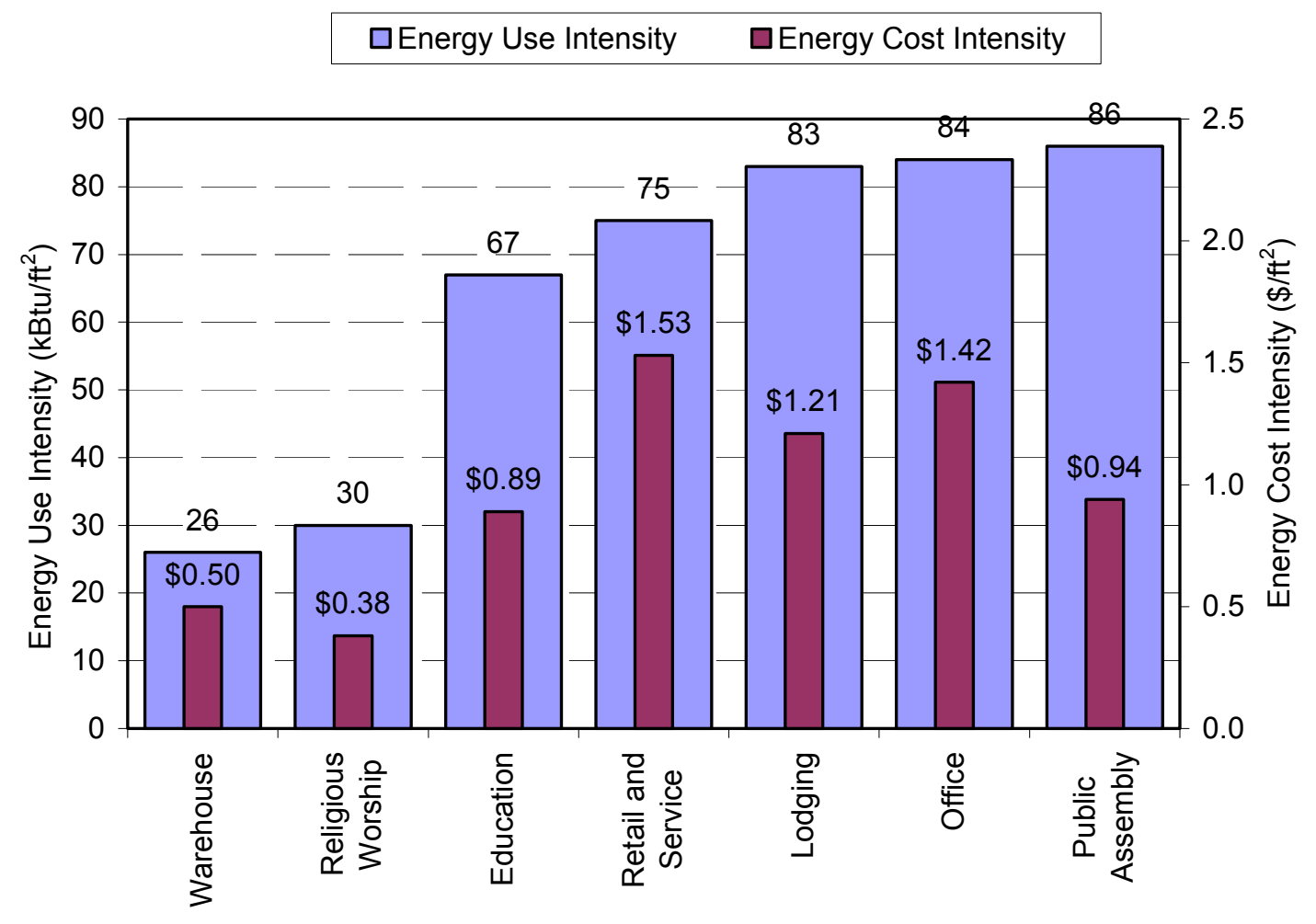

Figure 2-1 Site energy use and cost intensity by building type for commercial buildings in the West

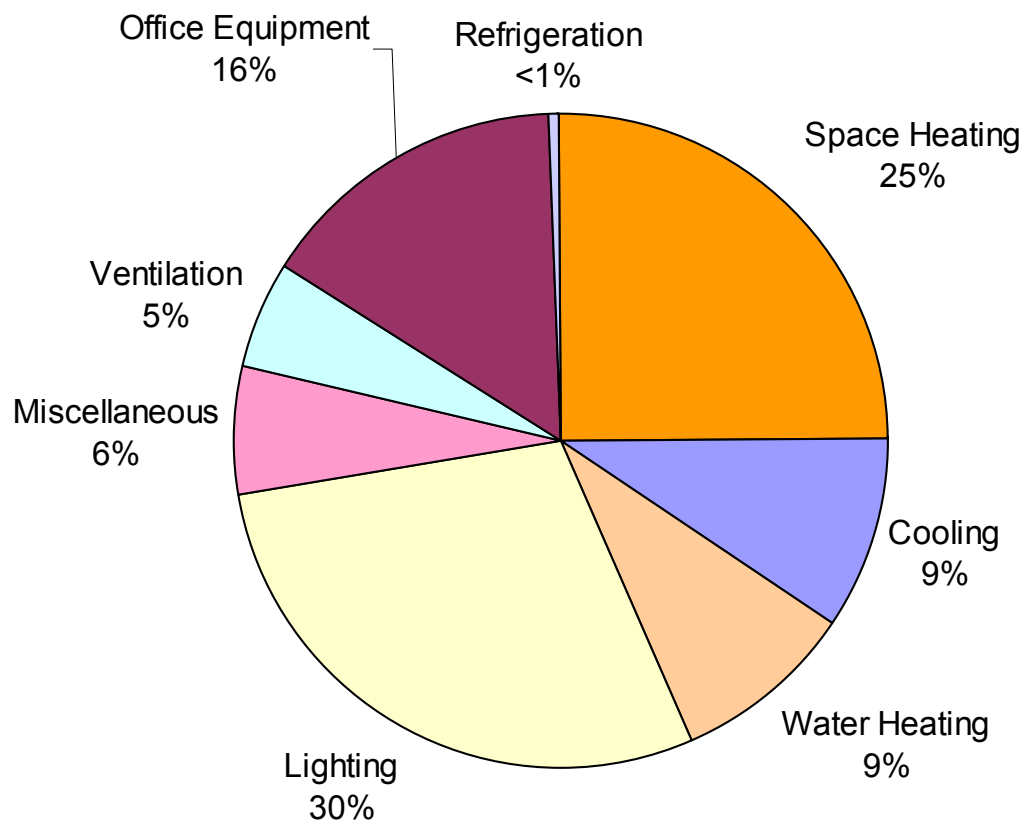

Figure 2-2 U.S. office building site energy consumption by end use, 1995 


\section{Design Process}

\subsection{Introduction}

The TTF's design team was selected based on previous work experience, cost, and familiarity of working with government agencies. Copeland Architects coordinated architecture and design, Burns and McDonnell managed mechanical and electrical design, Light Forms was the lighting consultant, SetPoint Systems Corporation was the control systems engineering consultant, J.C. Brooks and Company was the construction contractor, NREL research staff members acted as the energy consultants, and the NREL Site Operations Group managed the project.

The design process followed a process typically used for federal projects: design-bid-build. First, a conceptual design was completed. After funding approval, design development was completed and construction documents created. A competitive procurement was issued for construction that included limited commissioning. After occupancy, additional commissioning and modifications to some systems were done by NREL.

After DOE provided appropriate funding, the NREL Site Operations Group became responsible for management of the project. NREL procured architectural and engineering (A/E) services through a competitive process called a Task Order Agreement (TOA), whereby the selected A/E team provided a variety of individual project services. Qualifications for the TOA at that time were based on best value and low-energy architecture was not specified in the contract. Because of the design-bid-build process, the project had a fixed budget that could not be increased to accommodate low-energy design. A congressional budget of $\$ 1.15$ million was provided to cover all design, construction, and commissioning costs. At the project conception, the budget was the maximum allowed, by congressional limit, for construction of small laboratory buildings. Cost projections for the original conceptual design were $\$ 1.14$ million $\left(\$ 113 / \mathrm{ft}^{2}\left[\$ 1,216 / \mathrm{m}^{2}\right]\right)$.

This chapter highlights design decisions made during each phase and concludes with a section on the design process that was developed from the lessons learned during the design phase of this project.

The timeframe for the project, including monitoring, was from December 1992 to June 1998. Details of the timeframe are shown in Figure 3-1.

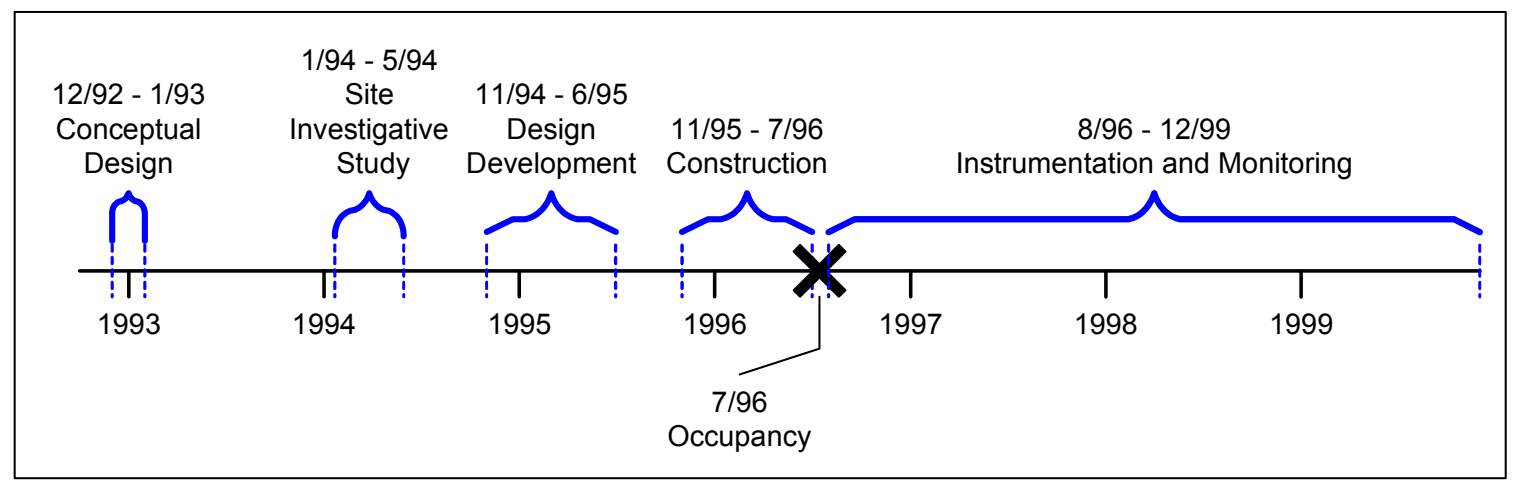

Figure 3-1 Timeline for TTF design, construction, and monitoring

\subsection{Conceptual Design}

Early space definitions were established by RNL Design, the subcontractor responsible for creating a Conceptual Design Report (CDR). The CDR included the type and use for the space and an approximate area that each function would incorporate. The total program size for the building was $10,000 \mathrm{ft}^{2}$ 
$\left(929 \mathrm{~m}^{2}\right)$, including mechanical space, kitchenette, restrooms, and a conference room. The remainder of the space was defined as high-bay laboratory space with a minimum ceiling height of $24 \mathrm{ft}(7.3 \mathrm{~m})$.

Table 3-1 summarizes the required spaces. The interior was to be easy to reconfigure to facilitate the construction, alteration, or removal of laboratory experiments. Changing research activities required that all utilities, including natural gas, electricity, and district hot/chilled water, be available and that these utilities be easily installed or removed with little additional cost. The government spending guidance limited the floor area to approximately $10,000 \mathrm{ft}^{2}\left(929 \mathrm{~m}^{2}\right)$.

All federal projects are subject to minimum energy-efficiency requirements. Designers were required to comply with the Code of Federal Regulations 10 CFR 435 (DOE 1995) when developing the building design. This code bases its energy-related requirements on a standard published by the American Society of Heating, Refrigerating, and Air-Conditioning Engineers, Inc. (ASHRAE) for commercial buildings (ASHRAE/IESNA Standard 90.1-1989). At the time the conceptual design report was completed, these two codes were identical, with one exception. The 10 CFR 435 had more stringent lighting power density requirements. Table 3-2 provides an overview of the requirements.

Although not quantitatively stated, a goal was set during this stage of the project to reduce the building's annual energy consumption through the use of energy-efficient and renewable-energy technologies.

NREL incorporated several technologies into the original conceptual design including: energy-efficient electric lighting; daylighting; low-energy heating, ventilation, and air-conditioning (HVAC); long eastwest axis, and direct digital controls. Additional funds from the project budget were not available for further energy efficiency improvements.

Table 3-1 Conceptual Design Space Requirements and Building Technology Criteria

\begin{tabular}{|c|c|}
\hline Criterion & Requirement \\
\hline Space & $\begin{array}{l}\text { Research/laboratory } \\
\text { Open-office } \\
\text { Conference } \\
\text { Restrooms } \\
\text { Kitchenette } \\
\text { Mechanical } \\
\text { Communications } \\
\text { Storage }\end{array}$ \\
\hline Height & $24 \mathrm{ft}(7.3 \mathrm{~m})$ \\
\hline Area & $10,000 \mathrm{ft}^{2}\left(929 \mathrm{~m}^{2}\right)$ \\
\hline Utilities & $\begin{array}{l}\text { Electricity } \\
\text { Natural gas } \\
\text { District hot water } \\
\text { District cold water }\end{array}$ \\
\hline Site & Smooth transition between surroundings and building \\
\hline Technology & $\begin{array}{l}\text { Integrated passive solar } \\
\text { High-performance envelope } \\
\text { Efficient electric lighting } \\
\text { Partial daylighting } \\
\text { Occupancy controls } \\
\text { Efficient HVAC design } \\
\text { Energy management system using Direct Digital } \\
\text { controls }\end{array}$ \\
\hline
\end{tabular}


Designers proposed a stair-step building design to meet the specified height requirements. Unlike a standard box configuration, the stair-step design integrated daylighting and passive solar features, while minimizing the volume of the space. It also reduced HVAC system capacity requirements. In addition, the design promoted natural convection for air distribution and a reduced volume of conditioned air. Complete air mixing could then be achieved by operating supplementary low-energy ceiling fans. Figure 3-2 diagrams the early ideas for how the conceptual building could integrate daylighting, passive solar, and efficient air distribution. Evaporative cooling was suggested at this early stage with designers noting that a direct/indirect evaporative cooling system could deliver $55^{\circ} \mathrm{F}\left(13^{\circ} \mathrm{C}\right)$ dry-bulb supply air at ASHRAE 1\% cooling design conditions for Denver and that a $100 \%$ outdoor air cooling would improve air quality inside the building.

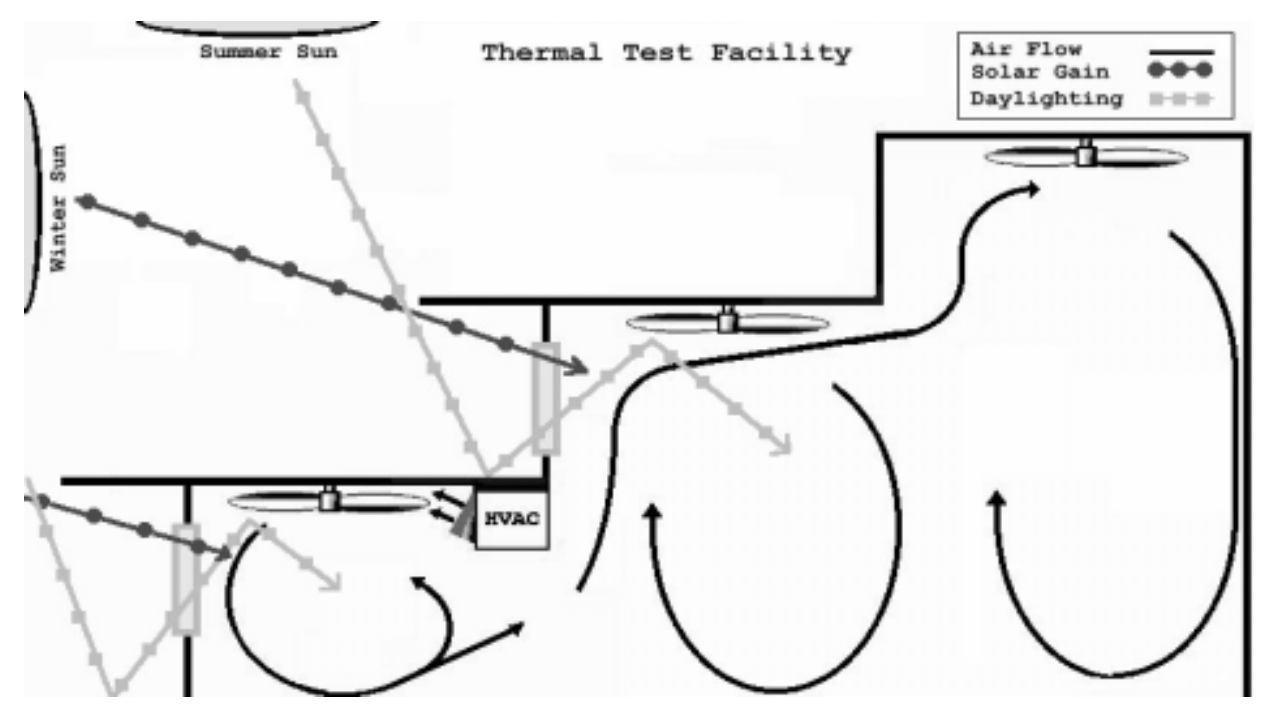

Figure 3-2 Early conceptual schematic for integrating low-energy daylighting, passive solar, and air distribution

Figure 3-3 is an artist's rendition of the conceptual design for the TTF, which includes solar-electric panels located along each of the TTF's stair-stepped tiers. Fenestration is primarily located on the south facade in the form of view-glass and clerestory windows; very little fenestration was placed on the east, west, and north facades. Architectural overhangs and fins integrated into the design of the building's exterior managed heating and cooling loads, depending on the season and angle of the sun. The conceptual design included a central core that incorporated the conference room, restrooms, closets, and kitchenette. The mechanical room was located at the building's eastern perimeter, and the entrance was situated on the east side. 


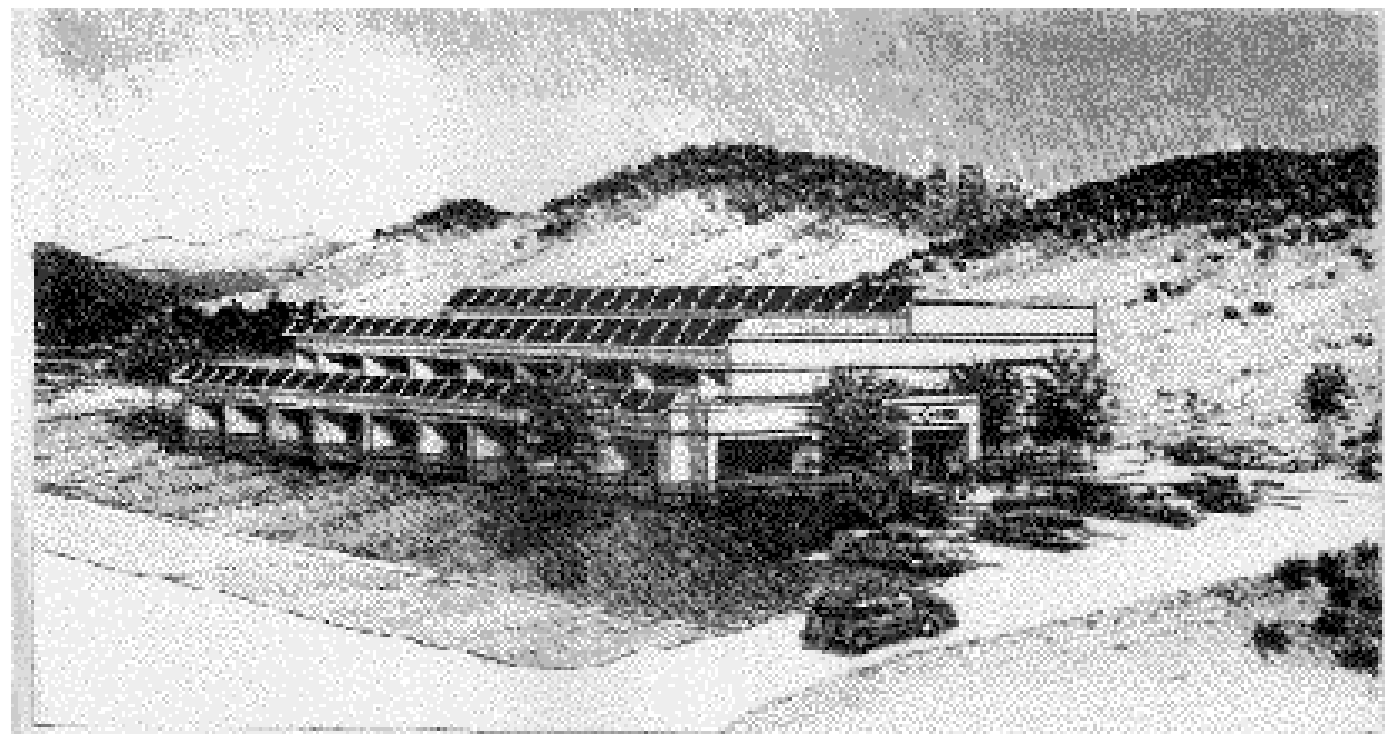

Figure 3-3 Rendition of the conceptual design for TTF

\subsection{Design Development}

A different contractor was used for design development. The architect for the design development phase was James Copeland. He and his staff were charged with taking the conceptual design and creating construction documents. The design contract was issued as part of a task ordering agreement that NREL maintains for general architectural and engineering services on the site.

During design development, NREL research staff became directly involved in the process. NREL proposed a far-reaching goal of reducing the building energy operating costs for HVAC and lighting by $70 \%$. After the entire design team agreed on this goal, they developed a plan for achieving the energy performance goal. The goal was set by a DOE programmatic goal that "next-generation" commercial buildings should use $70 \%$ less energy.

To achieve DOE's goal, NREL performed analysis and the design team implemented the results of the analysis. This plan involved parametric studies using computer simulations and careful integration of energy features with the building architecture. Mechanical systems were designed to work with the envelope of the building. NREL used the energy simulation computer program DOE-2.1E (Winkelmann et al. 1993) for modeling energy use and costs. In addition, the program SERI-RES (Palmiter et al. 1983) was also used to study thermal performance of the building envelope and passive solar designs. Both DOE-2.1E and SERI-RES have been validated by comparison to other building energy modeling programs using the BESTEST methodology (Judkoff and Neymark 1995).

The design team then realized they needed a benchmark to measure progress toward the goal. A base-case reference model was created based on a typical code-compliant building. The rationale was that a code compliant building is well specified by the code; therefore, this represents typical new construction, as most new buildings just meet code. The base-case reference model is described in Section 3.3.1. Next, a parametric study was performed to help guide the design team identify directions for the building design. Design parametric studies used to refine specifications are considered in the third subsection. 


\subsubsection{Base-Case Reference Model}

A base-case model was created as a reference to benchmark the performance of the TTF. This benchmark would later be used to determine cost and energy savings of the design and actual performance of the building. The base-case model was based on typical code-compliant buildings that are the same size as the TTF. The design of the building would start with the base-case building; it would then be altered to achieve the energy performance goal of a $70 \%$ reduction in energy cost.

This section presents the DOE-2.1E model of the base-case reference building for the TTF project. The reference building met the criteria for 10 CFR 435, the minimum energy standard for federal commercial buildings at that time. To create a building with this code, several assumptions were made:

- An equal footprint and wall area. (Note that the site investigation study found the footprint was fixed with respect to the CDR.)

- A total window-to-wall ratio of $13.3 \%$ applied equally on all sides for a "solar-neutral" building.

- A window $\mathrm{U}$-value of $0.55 \mathrm{Btu} / \mathrm{h} \cdot \mathrm{ft}^{2} \cdot{ }^{\circ} \mathrm{F}\left(3.1 \mathrm{~W} / \mathrm{m}^{2} \cdot \mathrm{K}\right)$ with a center of glass solar heat gain coefficient (SHGC) of 0.76 (shading coefficient of 0.88 ), a visible transmittance of 0.81 , and no overhangs.

- An insulation package specified by 10 CFR 435.

- A lighting density defined by 10 CFR 435. Lighting was considered "on" when each zone is occupied. Daylighting controls were not included.

- A variable-air-volume (VAV) mechanical system with a natural gas boiler for hot-water coils and a hermetically sealed centrifugal chiller with an air-cooled condenser. VAV mechanical systems are typical for buildings of this type and size in the Denver area. Supply fans were controlled to cycle on and off for heating, cooling, or outdoor air requirements.

- Plug loads, set-point schedules, and occupant loads would be identical between the buildings.

Actual values for the parameters used in the base-case are shown in Table 3-2. Typical meteorological year (TMY2) weather data for Denver, Colorado, were used for the weather file (NREL 1995).

Occupancy, lighting, and plug schedules are shown in Figure 3-4. The base-case model geometry is shown in Figure 3-5. 
Table 3-2 Overview of Base-Case Model Characteristics

\begin{tabular}{|c|c|c|}
\hline \multicolumn{2}{|c|}{ Building Characteristic } & Code Citation \\
\hline Stud Wall Insulation & $\begin{array}{l}\mathrm{R}-11 \mathrm{~h} \cdot \mathrm{ft}^{2} \cdot{ }^{\circ} \mathrm{F} / \mathrm{Btu} \\
\left(\mathrm{R}-1.4 \mathrm{~m}^{2} \cdot \mathrm{K} / \mathrm{W}\right)\end{array}$ & $\begin{array}{l}\text { Alternate Component Package } \\
\text { Listing } 8 \mathrm{~A}-28\end{array}$ \\
\hline Exterior Wall Insulation & $\begin{array}{l}\mathrm{R}-8 \mathrm{~h} \cdot \mathrm{ft}^{2} \cdot{ }^{\circ} \mathrm{F} / \mathrm{Btu} \\
\left(\mathrm{R}-1.9 \mathrm{~m}^{2} \cdot \mathrm{K} / \mathrm{W}\right)\end{array}$ & $\begin{array}{l}\text { Alternate Component Package } \\
\text { Listing } 8 \mathrm{~A}-28\end{array}$ \\
\hline Slab Insulation & $\begin{array}{l}\mathrm{R}-10 \mathrm{~h} \cdot \mathrm{ft}^{2} \cdot{ }^{\circ} \mathrm{F} / \mathrm{Btu} \\
\left(\mathrm{R}-1.8 \mathrm{~m}^{2} \cdot \mathrm{K} / \mathrm{W}\right)\end{array}$ & $\begin{array}{l}\text { Alternate Component Package } \\
\text { Listing } 8 \mathrm{~A}-28\end{array}$ \\
\hline Roof Insulation & $\begin{array}{l}\mathrm{R}-19 \mathrm{~h} \cdot \mathrm{ft}^{2} \cdot{ }^{\circ} \mathrm{F} / \mathrm{Btu} \\
\left(\mathrm{R}-3.3 \mathrm{~m}^{2} \cdot \mathrm{K} / \mathrm{W}\right)\end{array}$ & $\begin{array}{l}\text { Alternate Component Package } \\
\text { Listing } 8 \mathrm{~A}-28\end{array}$ \\
\hline Fenestration to Wall Ratio & $13.3 \%$ & $\begin{array}{l}\text { Alternate Component Package } \\
\text { Listing } 8 \mathrm{~A}-28\end{array}$ \\
\hline Lighting Density & $1.5 \mathrm{~W} / \mathrm{ft}^{2}\left(16.1 \mathrm{~W} / \mathrm{m}^{2}\right)$ & Table 3.4-1 (DOE 1995) \\
\hline Equipment Density & $0.75 \mathrm{~W} / \mathrm{ft}^{2}\left(8.1 \mathrm{~W} / \mathrm{m}^{2}\right)$ & Table 8-4 (ASHRAE 90.1-1989) \\
\hline People Density & $0.6 \mathrm{~W} / \mathrm{ft}^{2}\left(16.4 \mathrm{~W} / \mathrm{m}^{2}\right)$ & $\begin{array}{l}\text { Sec. 8.6.10.6 } \\
\text { (ASHRAE 90.1-1989) }\end{array}$ \\
\hline
\end{tabular}

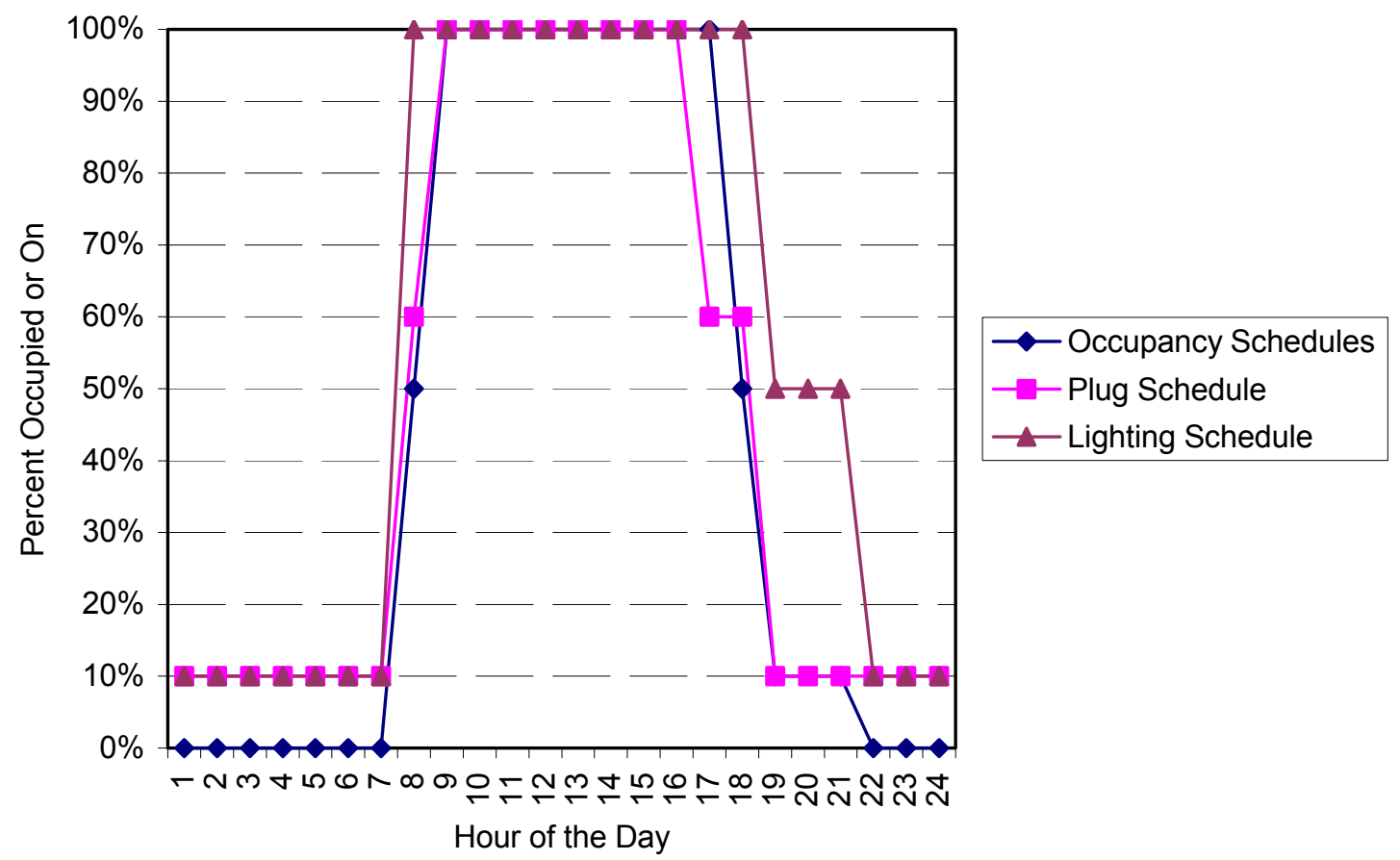

Figure 3-4 Base-case model schedules 


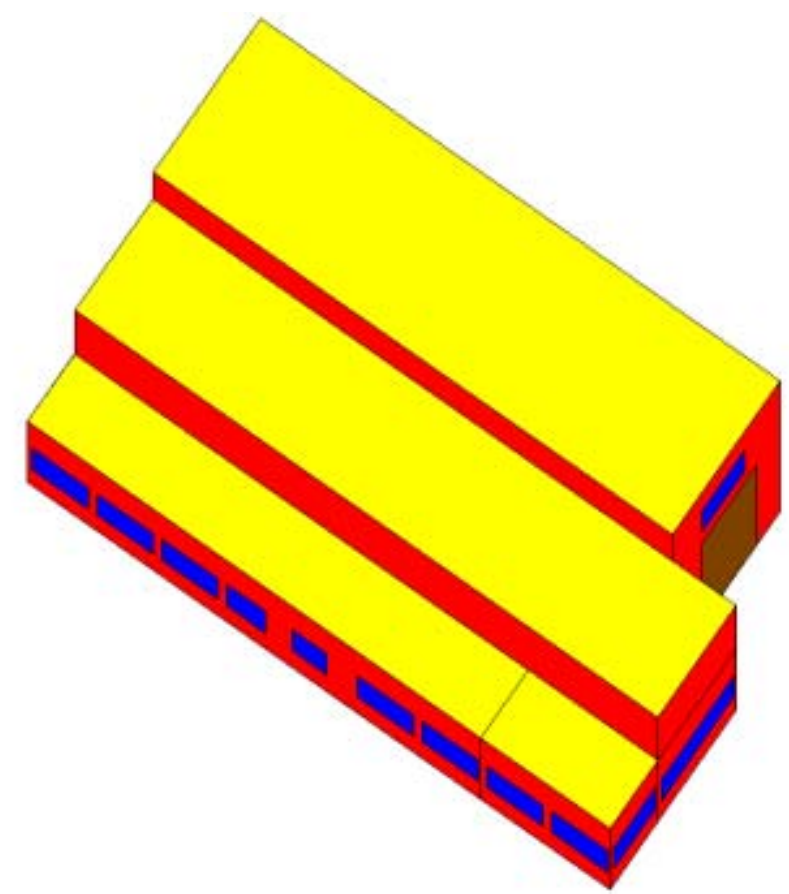

Figure 3-5 Base-case energy model geometry

Figure 3-6 shows the breakdown of annual energy operating costs obtained from the DOE-2.1E simulation of the base-case building model. A table of the simulated base-case and as-built energy costs is included in Section 4.9, Table 4-7. Equipment loads (plug loads) were not included in Figure 3-6 because these loads form part of the building use and should not be considered as part of a low-energy design. However, a plug-load electrical density value of $0.75 \mathrm{~W} / \mathrm{ft}^{2}\left(8.1 \mathrm{~W} / \mathrm{m}^{2}\right)$ was included in the models because of its influence on building heating and cooling. In this type of analysis, energy use pertains to services that the building provides to the occupants through HVAC and lighting equipment $(\mathrm{HVAC}+\mathrm{L})$. Energy costs were calculated using an electricity cost of $\$ 0.0248 / \mathrm{kWh}$, with an on-peak demand charge of $\$ 6.15 / \mathrm{kW}$ and an off-peak demand charge of $\$ 3.75 / \mathrm{kW}$. Natural gas costs were $\$ 0.385 /$ therm. The TTF is located on a centrally metered site. The rates are based on NREL utility bills at the time of the design. 


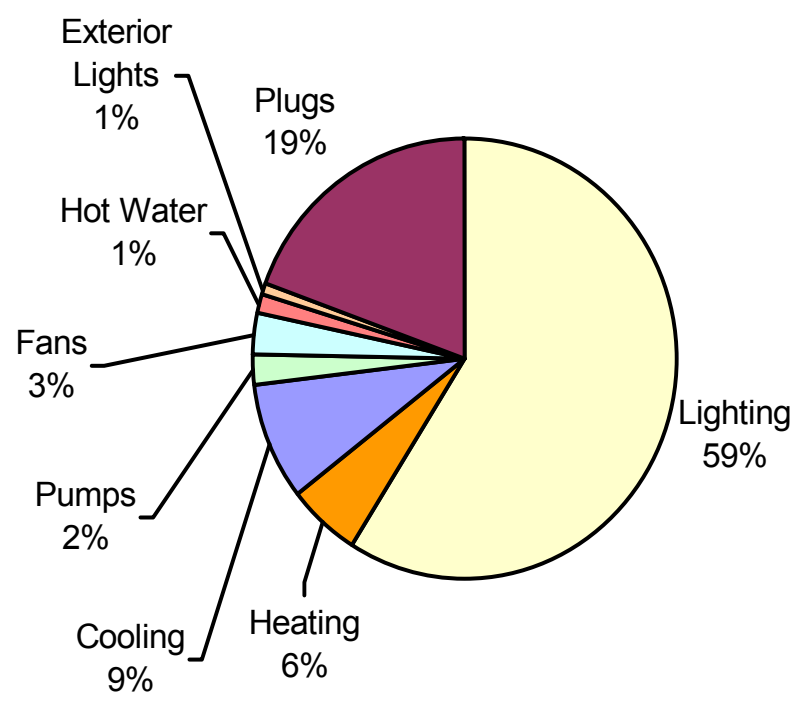

Figure 3-6 Base-case model results for energy operating costs

The base-case model showed that electrical lighting was the largest contributor to energy use and cost, responsible for nearly $60 \%$ of the building's annual energy operating cost. Cooling energy use was the second-largest contributor, responsible for nearly $9 \%$ of the energy costs. The results suggested that reducing the use of electric lighting and minimizing unwanted solar gains would improve the design.

\subsubsection{Elimination Parametric Study}

Next, NREL conducted an elimination parametric study. Elimination parametric studies have long been used to guide designer intuition because they focus on the source of energy consumption in buildings (Ternoey et al. 1985). Table 3-3 shows how separate aspects of corresponding loads were "eliminated" in order to investigate their contribution to the building's energy use. A simulation was performed for each parametric and the results used to guide design. Although not realistic, the analysis shows the maximum potential for eliminating a component of a building as well as interactions on other energy consumers in the building.

Table 3-3 Elimination Study Parameters

\begin{tabular}{|l|l|}
\hline \multicolumn{1}{|c|}{ Elimination Parameter } & \multicolumn{1}{c|}{ Value } \\
\hline No Lights & $0 \mathrm{~W} / \mathrm{ft}^{2} \quad\left(0 \mathrm{~W} / \mathrm{m}^{2}\right)$ \\
\hline No People & 0 occupants \\
\hline No Plug Loads & $0 \mathrm{~W} / \mathrm{ft}^{2} \quad\left(0 \mathrm{~W} / \mathrm{m}^{2}\right)$ \\
\hline No Ventilation & $0 \mathrm{ft}^{3} / \mathrm{min}(\mathrm{L} / \mathrm{s})$ \\
\hline Maximum Wall Insulation & $\mathrm{R}-99 \mathrm{~h} \cdot \mathrm{ft}^{2} \cdot{ }^{\circ} \mathrm{F} / \mathrm{Btu} \quad\left(\mathrm{R}-17.4 \mathrm{~m}^{2} \cdot \mathrm{K} / \mathrm{W}\right)$ \\
\hline Maximum Window Insulation & $\mathrm{R}-99 \mathrm{~h} \cdot \mathrm{ft}^{2} \cdot{ }^{\circ} \mathrm{F} / \mathrm{Btu} \quad\left(\mathrm{R}-17.4 \mathrm{~m}^{2} \cdot \mathrm{K} / \mathrm{W}\right)$ \\
\hline Opaque Windows & $\mathrm{SHGC}=0$ \\
\hline No Infiltration & 0 air changes/h \\
\hline
\end{tabular}


Figure 3-7 shows results for annual energy operating costs from the elimination study. Reducing the use of electric lighting offered the largest potential for saving energy. This energy-saving potential extended to the cooling load. However, eliminating electric lights increases heating energy, which is evident by comparing the amount of heating in the first two cases shown in Figure 3-7. Eliminating plug loads has similar consequences, but these loads are a function of the user and cannot be incorporated into the design of the building. Finally, minimal energy savings resulted from reducing ventilation, solar gains, infiltration, and maximizing the building's wall insulation.

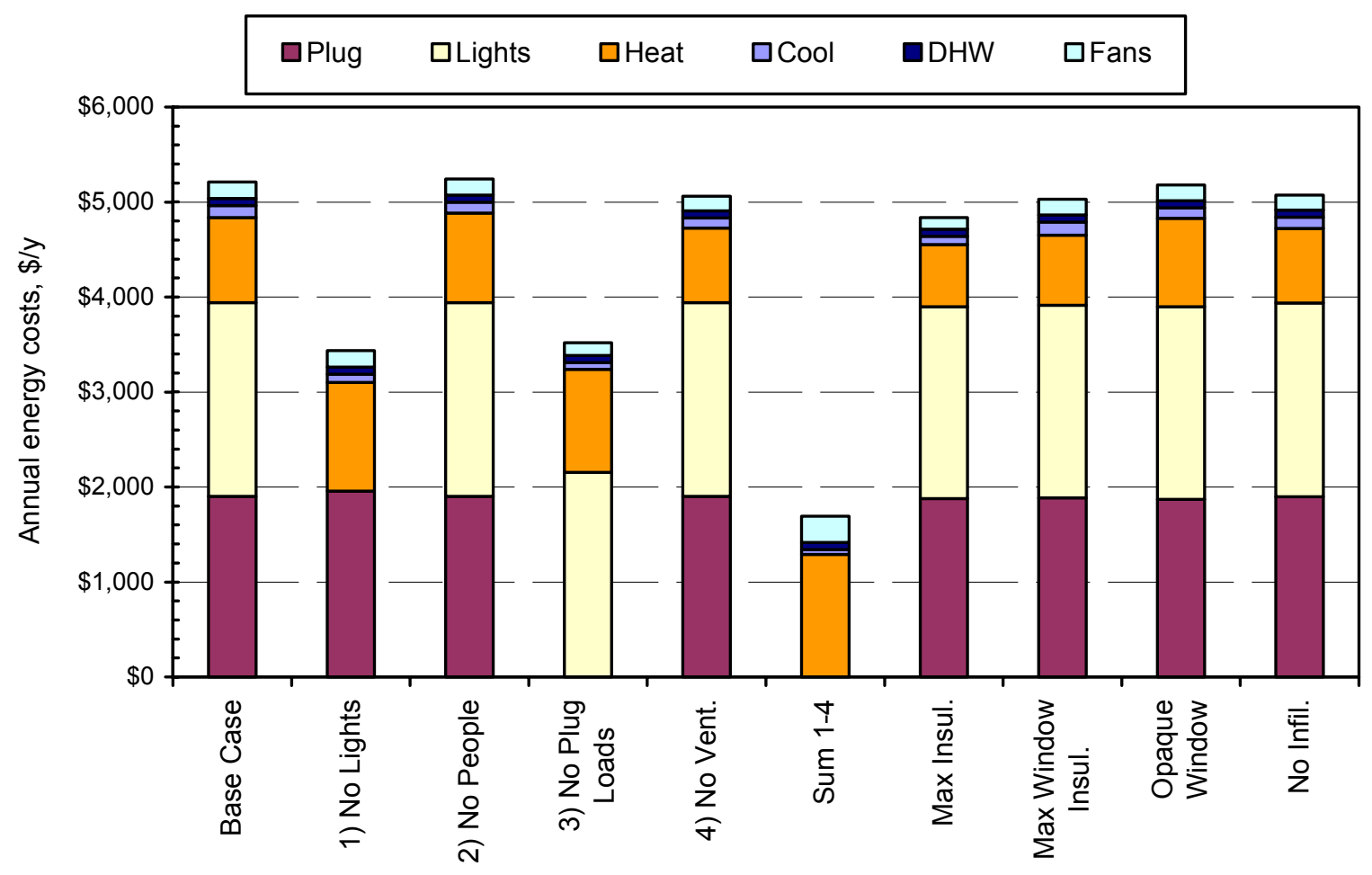

Figure 3-7 Elimination parametric results for energy cost

Solutions from the parametric study concluded that

- Some thermal losses could be reduced by increasing the amount of insulation

- Significant reductions could be made using daylighting

- Infiltration and ventilation are not a major issue

- Solar gains are useful to help heat the building in the winter.

These solutions were carried forward into the design of the building.

\subsubsection{Envelope Design}

To incorporate the results of the parametric study, NREL modified the base-case building and did computer simulations to refine the model. The resulting model had windows on the south side, with minimal windows on the east and west. The design team sized north windows at $1 \%$ of the wall area and added clerestory windows to provide daylighting to the high-bay. To improve the control of sunlight into 
the building, the window overhangs were sized from the Solar Radiation Data Manual (Marion 1995), as shown in Figure 3-8. Insulation levels and lighting design remained the same as the base-case model.

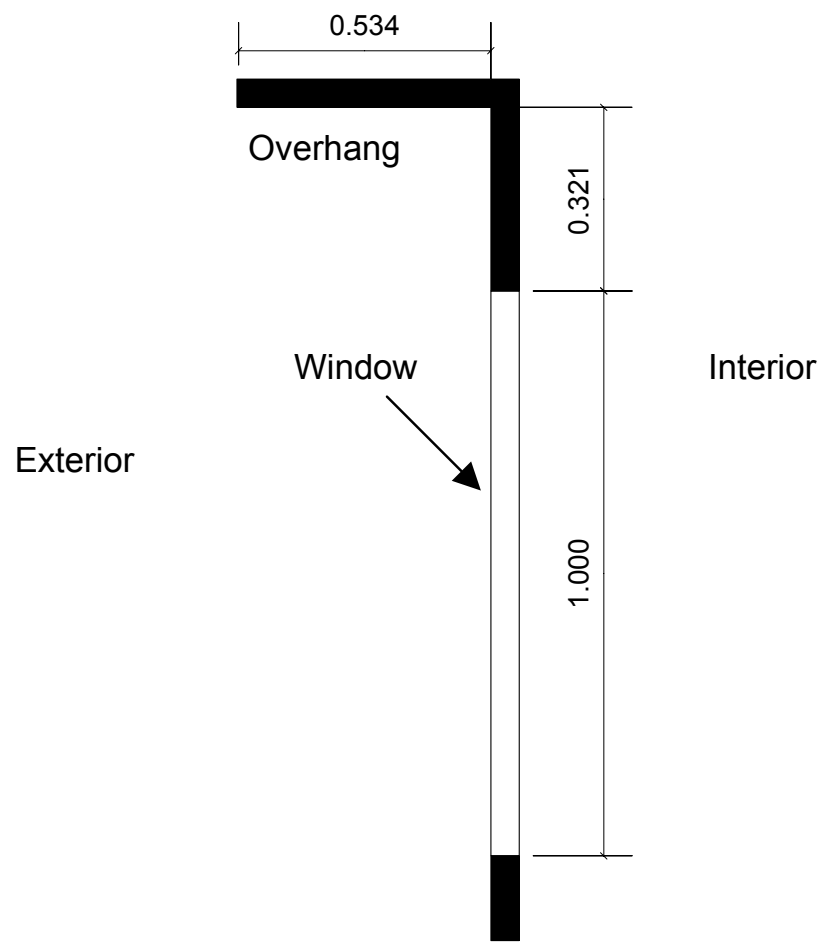

Figure 3-8 Overhang ratios for Boulder, Colorado, used for the starting point for the TTF analysis

The new model became the starting point for the design analysis. From this new model, NREL created a low-energy model and fine-tuned variables as the design evolved to meet the minimum requirements for architecture and safety. NREL integrated energy features whenever possible. Finally, the building had to be constructed within the fixed budget. The design team continually analyzed the design options to address the capital costs for the whole building, rather than the cost of adding specific energy features.

Because lighting was a significant load on the building, the design team maximized the daylighting. On/off controls were used to reduce electrical lighting based on available daylighting. In addition, the team optimized the clerestory height parameter. Varying the clerestory height parameter in the simulations accounted for changes in heat loss, solar heat gain, and lighting reduction from the clerestories.

Figure 3-9 shows partial results of the variation of clerestory height on the energy consumption for the building. The reduction of lighting energy nearly saturated at $3 \mathrm{ft}(0.9 \mathrm{~m})$. Additional increases in window area came with unwanted solar gains and increased heating and cooling loads. Note that changes to the later variables were small compared to the lighting contribution, which was consistent with the parametric and base-case analyses. At a clerestory height greater than $2 \mathrm{ft}(0.6 \mathrm{~m})$, the total energy consumption was almost independent of window size. The design team chose a final clerestory height of $3 \mathrm{ft}(0.9 \mathrm{~m})$ for energy cost reduction and architectural appeal. Although the cost of a 3-ft $(0.9-\mathrm{m})$ window was slightly more than a $2-\mathrm{ft}(0.6-\mathrm{m})$ window, the design team favored the increased architectural appeal. In addition, this window size fit well with the programmatic consideration for the step height and construction of the building. 


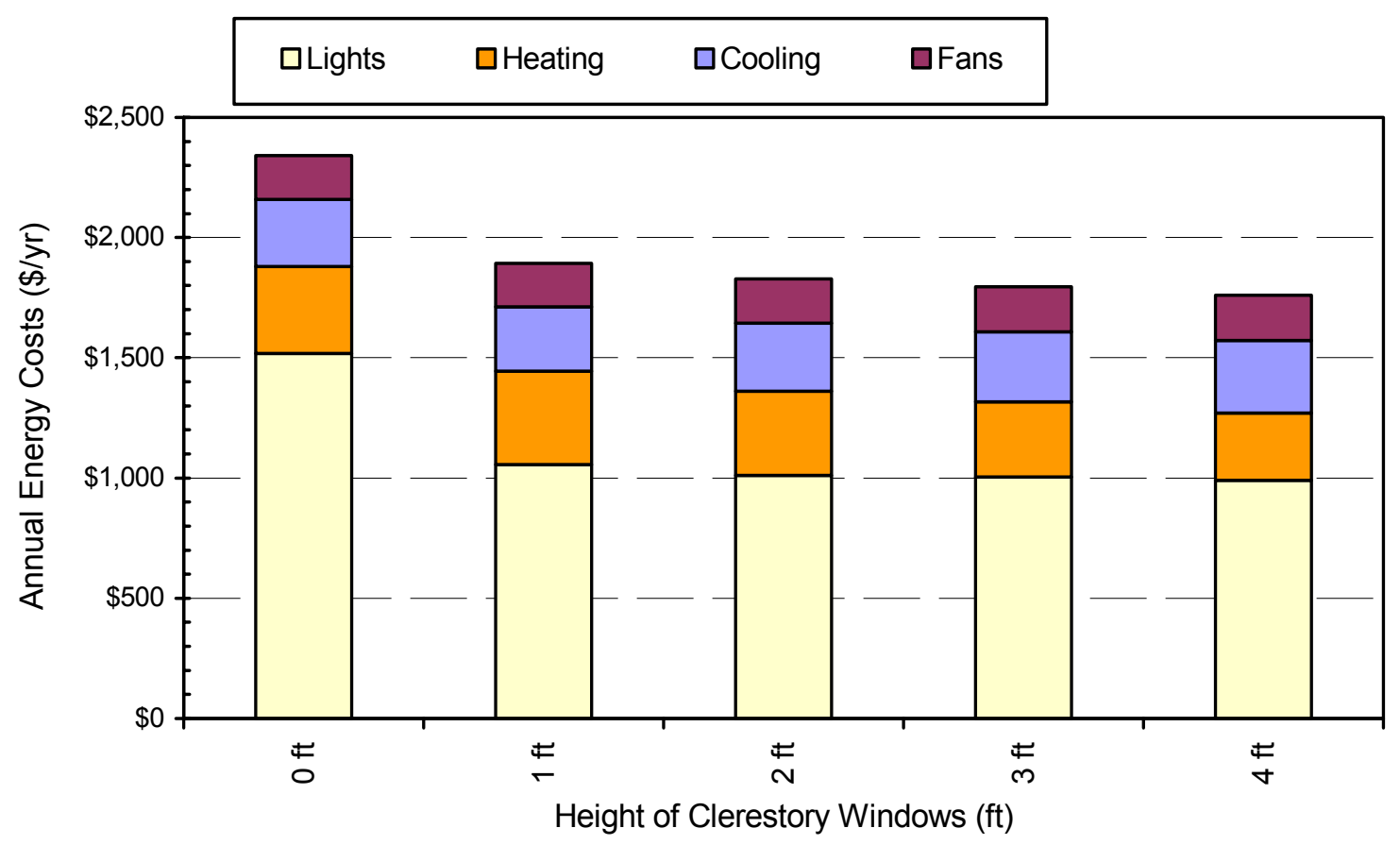

Figure 3-9 Impact of clerestory window height on annual energy cost

In similar fashion, the design team made other envelope design decisions such as overhang geometry (including length and offset from the window), glazing material selections, and insulation levels. The team selected low-emissivity (low-e) glazing for the clerestory windows based on simulation results. Although the visible transmittance was less than double-clear (base-case glass), the larger clerestory windows allowed for this reduction without sacrificing daylighting.

The design team sized the office windows for aesthetics and functionality. The result was excess solar gains in this space. The trade-off was longer overhangs and a slight gray tint to help reduce glare, visible transmittance, and solar heat gain. All these parameters were varied to determine the appropriate values during the design.

Additional considerations made during the design phase included moving the entrance to the south side of the building for easy access (parking was now provided on the south side of the building, rather than the east side). This design change allowed the building to be pushed back into the mesa. In addition, the design team added more mass to the building on the north wall as a structural measure for the building. The extra mass provided some limited energy savings and met requirements of the building structure. To lower the exterior roof temperature and potentially reduce cooling loads, the design team considered adding a white roof membrane, but the idea was abandoned because additional roof insulation resulted in the same energy savings at less cost. In addition, the white roof is subject to dirt, which reduces its effectiveness.

To reduce structural costs, further additions to the design included cross bracing behind the clerestory windows. This cross bracing slightly reduced the daylighting availability, but it significantly reduced the amount of steel (and cost) needed to construct the building. As these windows are located above the view plane, they did not detract from the building.

Although the impact was not evaluated, the design team incorporated several other features into the building. The team moved the mechanical room to the area above the restrooms in the mid-bay to create 
additional first-floor space in the east end of the building. Placing the service core in the center of the building improved daylighting in the low-bay areas and allowed for reflection and diffusion of light from the mid-bay clerestories, as shown in Figure 3-11.

Fins were designed to match the overhangs on the south, east, and west facades for architectural reasons. Simulations showed that there was a slight decrease in energy performance from the addition of the fins as well as additional construction costs. Although not quantified, they did reduce morning and afternoon glare in the offices.

\subsubsection{Mechanical and Electrical Design}

After the envelope was designed, the design team selected a mechanical system based on the loads of the building. See Section 4 for a description of the as-built envelope, lighting, and HVAC systems. A 100\% outdoor air direct/indirect evaporative cooling system provided cooling to the laboratory and office spaces. Next, the team selected a direct-expansion (DX) packaged air conditioner to provide cooling to the conference room. VAV boxes with hot water coils provided the heating. NREL's central heating plan supplied the hot water.

During this phase, the electrical loads were segregated into lighting, HVAC, and plug loads. Each of the major end loads was isolated by a respective panel box such that end loads could easily be monitored.

\subsubsection{Plan and Construction Document Preparation}

After the design was completed, the team carefully checked the plans for thermal bridging. They specified several areas as problem areas. Poor insulation can also lead to condensation and water problems on a building.

- Detailing around the overhangs. There were gaps on the original plans between steel and the overhang connections.

- Detailing at top of the roof parapet. The exterior of the building was well insulated, but the tops and the inside surface of the parapets allowed for thermal bridging.

- Ground connection. Insulation was added to the interior of the foundation step walls to a depth of $3 \mathrm{ft}(0.9 \mathrm{~m})$ to minimize thermal bridging from the slab to the exterior ground.

Design team members also reviewed specifications and operating sequences for consistency against the original design intent of the building.

\subsection{Construction}

The official TTF groundbreaking ceremony took place on May 23, 1995. The total building cost was $\$ 1,187,287$, which represents $\$ 111.15 / \mathrm{ft}^{2}\left(\$ 1,196.43 / \mathrm{m}^{2}\right)$. Appendix C provides a breakdown of the payments. NREL facilities personnel monitored the TTF construction to ensure that it was built according to plan. In addition, NREL research staff also watched construction; in particular, the construction of the energy aspects was carefully monitored.

Several variations to the plans occurred during construction. This section highlights these changes and the possible impact. Some changes increased the project scope and formal change orders had to be implemented. Appendix D provides a list of change orders and their associated costs. Some changes were not fixed, as the opportunity in construction passed and correction was not feasible. The contractor omitted some energy aspects and correction was made at the contractor's expense.

In addition, the contractor used very little electric lighting during construction. The TTF's daylighting design provided sufficient light levels during most of the building's construction. The use of daylighting during construction resulted in a reduced construction cost from decreased energy, materials, and labor 
requirements. The daylighting saving was not accounted for in the construction bid; in the future, daylighting saving during construction can be used as a mechanism to show reduced cost of construction.

Table 3-4 highlights construction problem areas by presenting the differences between the design intent and the "as-built" building.

Table 3-4 Main Differences between the Original and As-Built Construction Documents

\begin{tabular}{|c|c|c|}
\hline Item & Design Intent & As-built Construction \\
\hline $\begin{array}{l}\text { North Wall 2-in Polystyrene } \\
\text { Insulation }\end{array}$ & $\begin{array}{l}\mathrm{R}-10 \mathrm{~h} \cdot \mathrm{ft}^{2} \cdot{ }^{\circ} \mathrm{F} / \mathrm{Btu} \\
\left(\mathrm{R}-1.8 \mathrm{~m}^{2} \cdot \mathrm{K} / \mathrm{W}\right)\end{array}$ & $\begin{array}{l}\mathrm{R}-5 \mathrm{~h} \cdot \mathrm{ft}^{2} \cdot{ }^{\circ} \mathrm{F} / \mathrm{Btu} \\
\left(\mathrm{R}-0.9 \mathrm{~m}^{2} \cdot \mathrm{K} / \mathrm{W}\right)\end{array}$ \\
\hline $\begin{array}{l}\text { Perimeter Floor Insulation on } \\
\text { Interior to R-10 }\end{array}$ & Position as detailed & $\begin{array}{l}\text { Not installed at edge of slab. } \\
\text { Installed below slab } \\
\text { (horizontally); area missing: } \\
390 \mathrm{ft} \text { by } 6 \text { in. } \\
(118.9 \mathrm{~m} \text { by } 15.2 \mathrm{~cm})\end{array}$ \\
\hline Exhaust Louver Placement & $\begin{array}{l}\text { Highest possible height on } \\
\text { east high-bay wall; this is } \\
\text { approximately } 24 \mathrm{ft}(7.3 \mathrm{~m}) \\
\text { above the floor }\end{array}$ & $\begin{array}{l}\text { Placed at mid-height on east } \\
\text { high-bay wall [height is } 14 \mathrm{ft} \\
(4.3 \mathrm{~m})]\end{array}$ \\
\hline Evaporative Unit Access & $\begin{array}{l}\text { Provide access to } \\
\text { evaporative cooling medium }\end{array}$ & $\begin{array}{l}\text { No access provided to } \\
\text { evaporative cooling medium; } \\
\text { limited access later provided }\end{array}$ \\
\hline $\begin{array}{l}\text { Evaporative Unit Drain Pan } \\
\text { Location }\end{array}$ & $\begin{array}{l}\text { Construct on-site, place on } \\
\text { exterior of unit beneath unit }\end{array}$ & $\begin{array}{l}\text { Pit too shallow, seems poorly } \\
\text { fastened }\end{array}$ \\
\hline $\begin{array}{l}\text { Daylight and Occupancy } \\
\text { Detection }\end{array}$ & $\begin{array}{l}\text { Install daylight and } \\
\text { occupancy sensors }\end{array}$ & Installed only daylight sensors \\
\hline $\begin{array}{l}\text { Thermal Breaks in Door and } \\
\text { Window Frames }\end{array}$ & $\begin{array}{l}\text { Purchase units with } \\
\text { thermally broken frames }\end{array}$ & $\begin{array}{l}\text { Units purchased and installed } \\
\text { without thermally broken frames }\end{array}$ \\
\hline
\end{tabular}

\subsubsection{Insulation Details}

Perimeter slab insulation was specified on the inside of the foundation for ease of installation. The concept was the interior insulation would not need to be fitted around the fins and the insulation would be better protected during construction. During construction, structural concerns with the interface between the slab and the exterior walls resulted in the removal of some of this insulation. By the time the construction decision was discovered, the location had already been backfilled, making it too costly to add the insulation on the exterior of the building. Consequently, a 6-in. (15.2-cm) thermal bridge is located around the perimeter of the concrete slab. The largest impact is on thermal comfort near the perimeter of the building. Although difficult to quantify, the result is probably higher space temperatures to offset the impact of the colder floor.

Insulation values specified for the north tilt-up concrete wall were not detailed properly. Although 2 in. $(5.1 \mathrm{~cm})$ of expanded polystyrene (EPS) foam was specified, a low-density polystyrene product was used. The thermal performance of EPS depends strongly on density. (Lower density foam has lower thermal performance and costs less.) The product should have been specified on thermal performance and not on thickness. The design intent was to have R-10 $\left(1.8 \mathrm{~m}^{2} \cdot \mathrm{K} / \mathrm{W}\right)$ on the exterior of the wall rather than R-5 $\left(0.9 \mathrm{~m}^{2} \cdot \mathrm{K} / \mathrm{W}\right)$. Although the overall impact of each discrepancy is minimal, the net effect on the energy savings due to the sum of all the discrepancies is evident. The effect on energy savings is discussed in Section 5.4.1.2. 


\subsubsection{Mechanical and Electrical Systems}

The relief damper for removing surplus air from the building during cooling was not positioned as intended. According to the plans, this damper was to be placed "as high as possible" on the east high-bay wall. The plans, however, showed this damper located at the same height as the top of the garage door. The design intent was to relieve the warmest air in the building in order to maximize the effectiveness of heat extraction during cooling. The relief damper is visible to the right of the roll-up door in the photograph shown in Figure 3-10. Instead, the damper was placed at mid-height on the high-bay east wall, causing warm air to be trapped in the upper half of the high-bay area. It was considered too difficult and expensive to relocate the damper after installation. Because the definition of "as high as possible" was not defined beforehand, there was no leverage with the contractor to move the damper. Locating the damper higher on the wall would have allowed natural ventilation to be used as a first stage of cooling. No fluid analysis was done on the building, so the impact of this change is unknown and is beyond the scope of this evaluation.

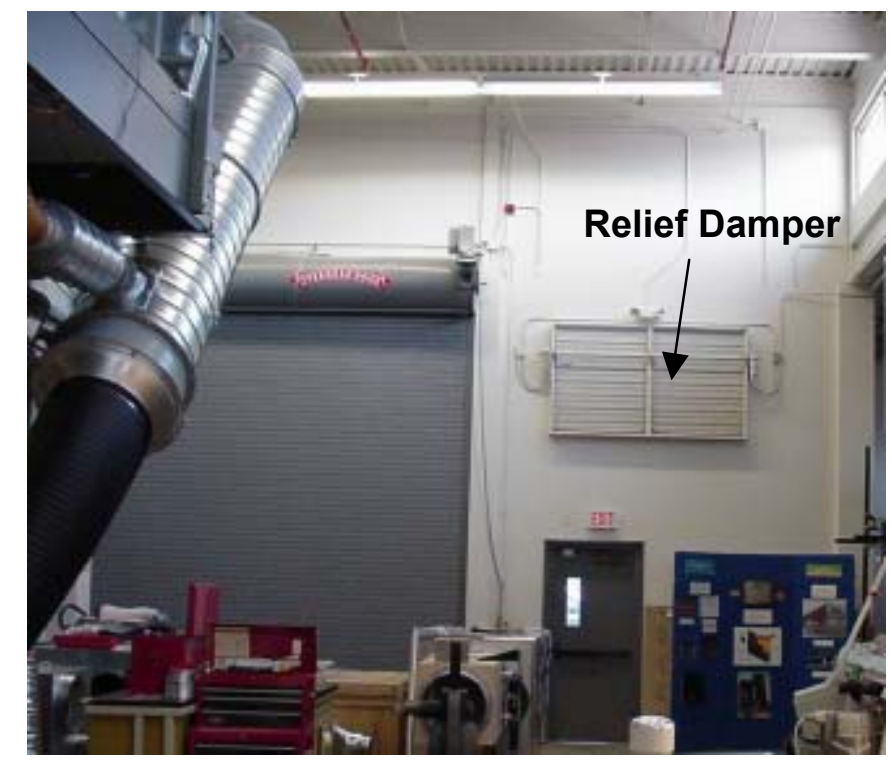

\section{Figure 3-10 Relief damper location on east high-bay wall}

The contractor also did not provide access to the evaporative cooling medium and its associated plumbing in the direct/indirect evaporative cooling unit, even though it was indicated in the specifications for the unit. The lack of access made maintenance of the evaporative cooling unit virtually impossible without altering the system. Additional work was done by the contractor to add access to the medium and plumbing. The solution was less than optimal and removal of medium may still be difficult. Although not an energy issue, it is a maintenance issue.

The specifications also required that the sump pit for the evaporative cooler be located for easy maintenance. The delivered equipment did not meet these specifications, so the cooler was retrofitted onsite. The resulting design of the drain pan, along with associated plumbing and pumps, resulted in many evaporative system breakdowns during the first two summers. Although not an energy issue, it is a maintenance issue.

Because the TTF included nonstandard types of equipment, the contractor had difficulty installing controls. The design team specified separate controls for the indirect and direct portions of the evaporative cooler, but they were initially installed to only operate simultaneously. The ceiling fans were to be controlled by the energy management system (EMS) for direction and speed, but this was also not done. NREL corrected the first error easily. The ceiling fans needed extensive rewiring and a second 
EMS panel. The contractor could not find a speed control; however, NREL found a suitable product. To reverse the fans, additional high-voltage wires were run. NREL and the contractor reached a compromise about the features, resulting in a small change-order fee.

NREL research staff discovered that the building's daylighting control system was not integrated with the occupancy sensors. The result was that sensors functioned properly when the lights were turned off in response to daylight; however, at night, all the lights remained on, even though the building was not occupied. This mistake was an error in the relationship of the specifications to the plans. Two types of sensors were specified in the plans. One specification was for daylight-only sensors. The other was for daylight and motion. The first specification was used for the main part of the building and the second was used for the nondaylit portions of the building. The contractor installed the specified product in the main part of the building (daylight-only sensors) and motion/daylight sensors in the nondaylit portions (motion/daylight sensors were not specified at all; however, these sensors were appropriate for this location). To correct the problem, NREL installed daylight and motion sensors in the daylit portion of the building after the contractor completed the project. Note that NREL made several other changes to the lighting control, as discussed in Section 6.1.

After construction was completed, NREL determined that the contractor did not install thermally broken windows and doorframes. Although the design team originally agreed to include these energy-saving features, the frames that were installed were not thermally broken. Documentation indicates that the products purchased were those specified. It is not clear why the requested frames were not included in the building. At the time of construction, the marketing of energy-efficient window products led to confusion in the field; activities of the National Fenestration Rating Council has since partly remedied the problem. It is critical that door and window frames be carefully specified with resistance values and that construction management has a mechanism for evaluating such products in the field to ensure that they are installed according to design intent. Analysis of this issue is discussed in Section 5.4.1.2.

\subsection{Commissioning}

J.C. Brooks, the construction contractor, along with its associated subcontractors, commissioned the building's electrical and mechanical systems. The building's HVAC systems were balanced and the control system programmed according to an operation outlined on the drawings. Daylighting and occupancy sensors were tuned to $40 \mathrm{fc}$ (400 lux) as indicated on the plans. Airflows were balanced to the levels shown on the plans. Motion sensors were verified. The commissioning was considered basic and limited to the testing and balancing of equipment. No significant operational problems were discovered during the commissioning process.

In addition, NREL staff began to evaluate equipment and correct issues related to operational performance; they also compared operation of the building against an as-designed model. The level of effort was beyond the scope of traditional commissioning. This section and the next section discuss commissioning activities and postoccupancy changes performed by NREL staff. Most of next section is dedicated to documenting items that were beyond the scope of the traditional commissioning done by the contractor. This work is documented in Section 3.6.

\subsection{Modifications from Original Design}

At the onset of the monitoring, and in the first few months of occupancy, several issues were corrected that affected the energy use of the building. These activities occurred after the contractor had been released from the contract - that is, postcommissioning. 


\subsubsection{Electric Lighting System Alterations}

The original design called for the building's EMS to use separate daylight sensors for each lighting zone. However, during postcommissioning, NREL found it too difficult to calibrate the sensors in each zone, so oscillations frequently occurred when the sensors detected light from a neighboring zone. The result was cyclic on/off sequences that could not be stabilized with the hardware provided. Because the system lacked motion-sensing equipment, the lights were activated all night long with no mechanism to turn them off - clearly a design and hardware (both installation and specification) flaw. Therefore, NREL changed the original lighting control system to use a single sensor that measured daylight availability for the building. Figure 4-8 shows the sensor selected to measure illumination levels and control the building's supplementary electric lighting system. The EMS uses this information to control electric light status. The single sensor is located just inside the high-bay clerestory window. Because the daylight is mostly from south-facing fenestration, the data from a single sensor can be used to provide separate control for each individual zone. The lighting level set points with respect to this sensor are unique for each lighting zone and set to provide necessary light levels.

The daylighting and occupancy controls were the first building systems to be renovated. The occupancy controls turn the lights on and off in individual zones. Since the building was constructed, NREL has revised the system three times. The first revision occurred during the construction phase when it was discovered that the daylighting control system was not integrated with occupancy sensors. (See Section 6.1.) Electric lights continued to operate throughout the night. To meet the design intent, daylighting sensors were replaced with combination motion and daylight sensors in seven daylit zones in the building. Sensors were calibrated as part of the building commissioning. After occupancy, it was quickly realized that this solution, although functional, did not work well in an office/laboratory environment. Sensors were quick to cycle on and off, and the daylighting controller caused short-cycling. Because the lighting system is on/off, the rapid changes were distracting to the occupants. Tuning sensors was difficult because of their physical location, especially those located in the mid- and high-bays.

A second revision of the lighting control system occurred about six months after the building was occupied. The motion portion of six of the sensors was tied to the EMS. In addition, a single analog light-level sensor was installed in the high-bay near the upper clerestory. The sensor was attached to the EMS, as well as the control relays for the light fixtures. The EMS was programmed to monitor change in both occupancy status and illumination levels. Depending on individual zone set points, which were now easily adjusted through computer interface, electric light operation could be automatically controlled using one daylight sensor for the entire building. Calibration was simplified, and the ability to test different control strategies was achieved. Note that one zone remained on the motion/daylight sensorthe hallway between the low-bay and the service core of the building. This area is considered emergency lighting. It is not sensitive to the on/off cycles and constant light level is not critical. The simple solution was acceptable to NREL security as an alternative to providing security lighting 24 hours per day. NREL calibrated the sensor so that any movement at the doorway would turn on these lights. Also note that these security lights are off when even a small amount of daylighting is available.

In addition, NREL developed advanced control algorithms for the EMS that reduced unnecessary on/off cycling of the electric lights by monitoring changes in illumination levels and statistically determining future cycling. If the skies are partly cloudy and the EMS determines that the lights will have a high chance of cycling in the near future, the EMS will continue to operate the lights until it senses a consistent environmental change. The system's operation is designed to be relatively conservative, and it incorporates long on-periods (especially on variably cloudy days) to avoid bothering occupants who are apt to be disrupted by short light-cycle operations. These advanced control algorithms significantly reduce calibration time and effort, while improving occupant satisfaction of the electric lighting system. A full evaluation of this system is in Section 6.1. 
To control low-solar angle glare issues, NREL added horizontal blinds to the interior of the mid-bay clerestory windows. The building was designed to provide light scattering off the light-colored mid-bay wall, but the intensity of the sunlight resulted in glare problems for nearby office cubicles. Figure 3-11 shows the direct sun on the mid-bay wall. Figure 3-12 shows the mid-bay with the blinds adjusted to eliminate the direct glare into the space. Glare is not a problem in the summer months when overhangs block direct gain. Currently, the clerestory blinds are adjusted twice a year, once during the fall and again in the spring. Occupants adjust window blinds on view windows in the conference room and south offices as needed. In addition, the nature of the experimental work in the west mid-bay necessitates no direct gain - which would affect the thermal calibration of the experiments.

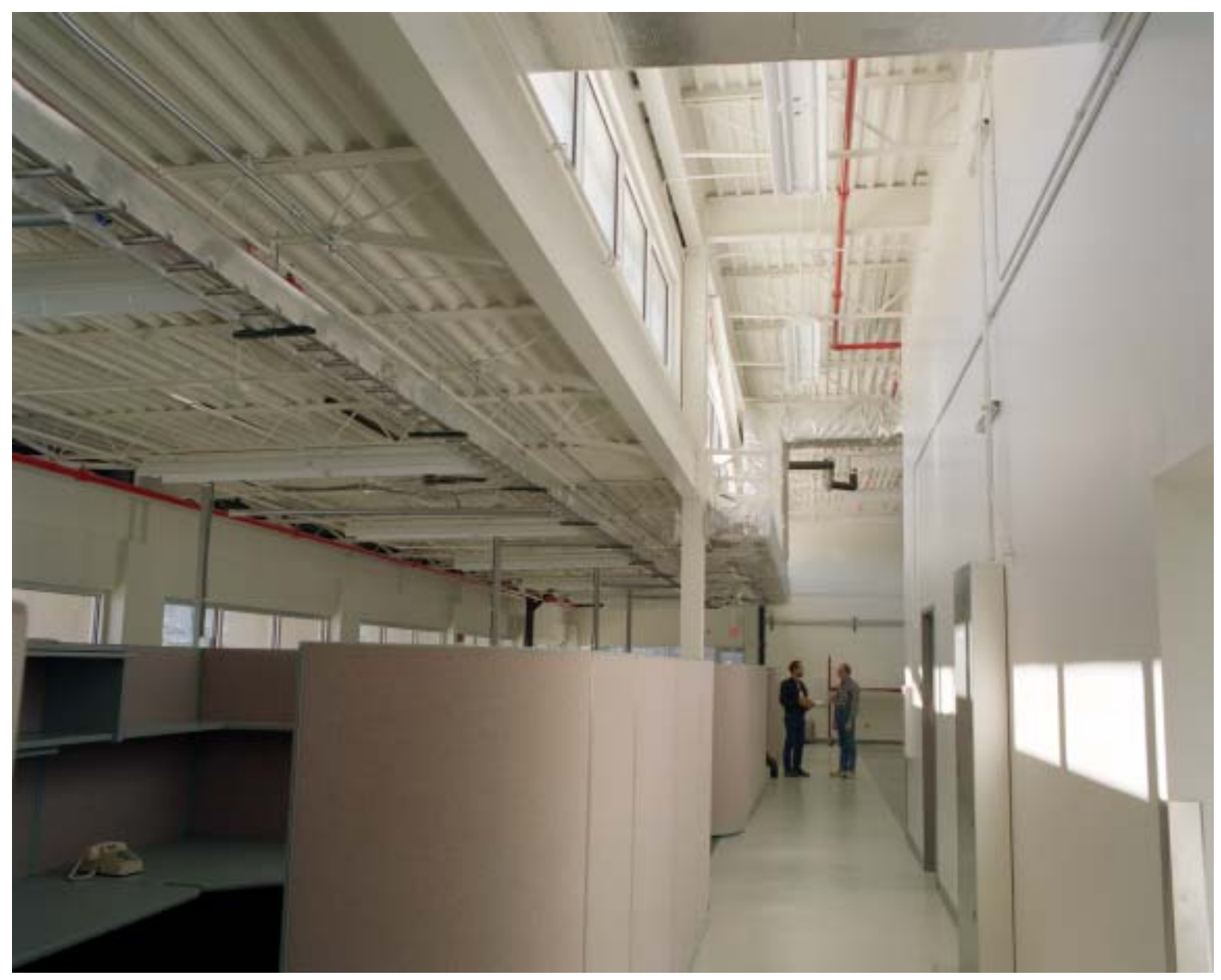

Figure 3-11 Mid-bay clerestory daylight at low-sun angles before installation of blinds 


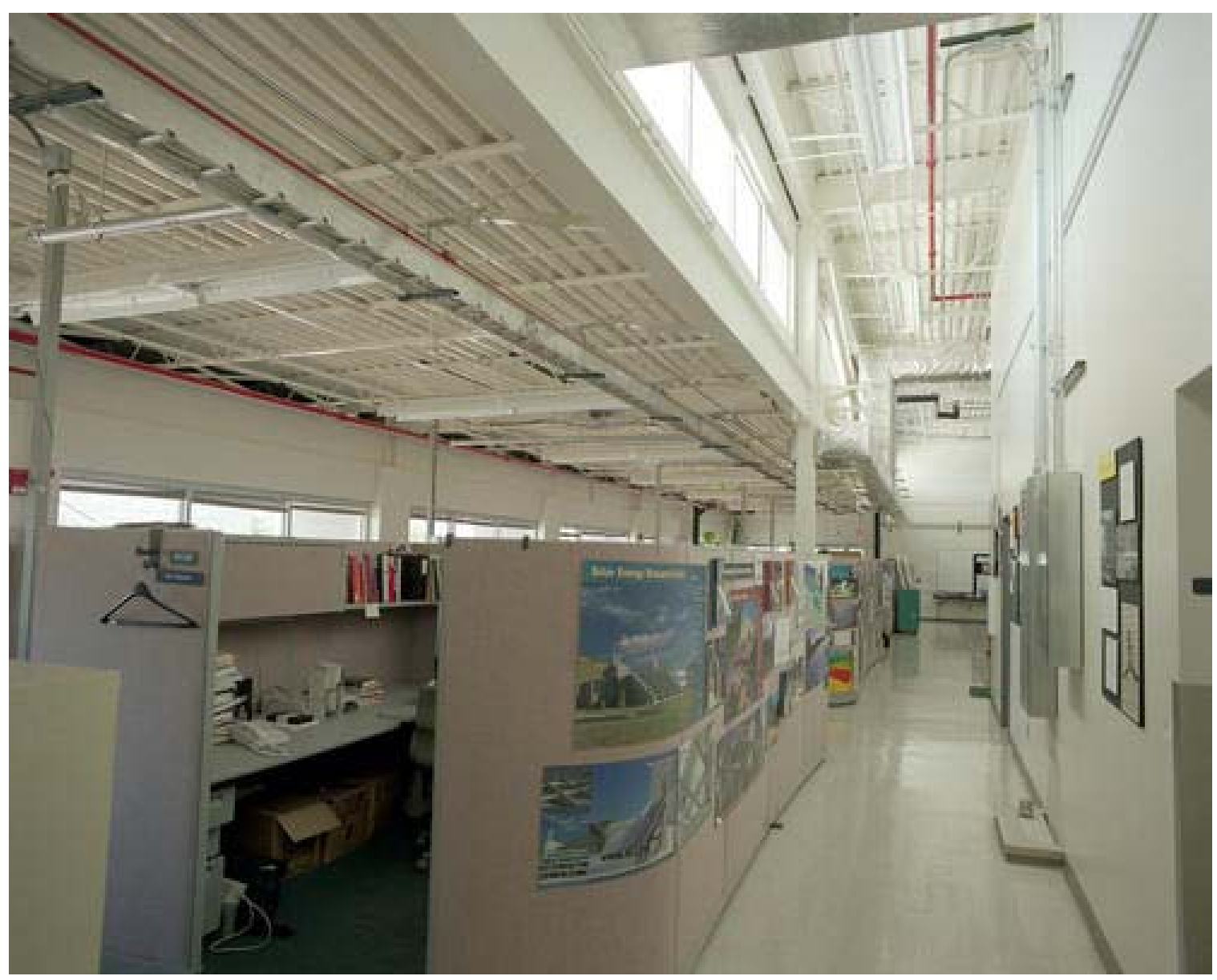

Figure 3-12 Mid-bay clerestory daylight at low-sun angles after installation of blinds

\subsubsection{HVAC System Alterations}

\subsubsection{Evaporative Cooling System}

The evaporative cooling unit underwent many alterations to improve its efficiency and reliability. When the building was first occupied, the cooling system did not operate properly. The general contractor and architect were contacted. The engineer for the architect responded that an evaporative system could not meet the load; however, NREL staff monitored the system and observed that the unit's performance was significantly lower than specified by the manufacturer. Finally, NREL staff dismantled the unit to find that the direct section was not plumbed properly and the cooling medium was not wet. Only a small portion of the cooling medium was being hit with pumped water, leaving the rest completely dry. Although the direct suction pump was operating normally, the nozzle responsible for spraying water onto the evaporative medium was never properly attached, as shown in Figure 3-13. The investigation was complicated by the fact that the medium was not accessible as indicated in the specifications. This inaccessibility affects maintenance as well as commissioning of the building. 


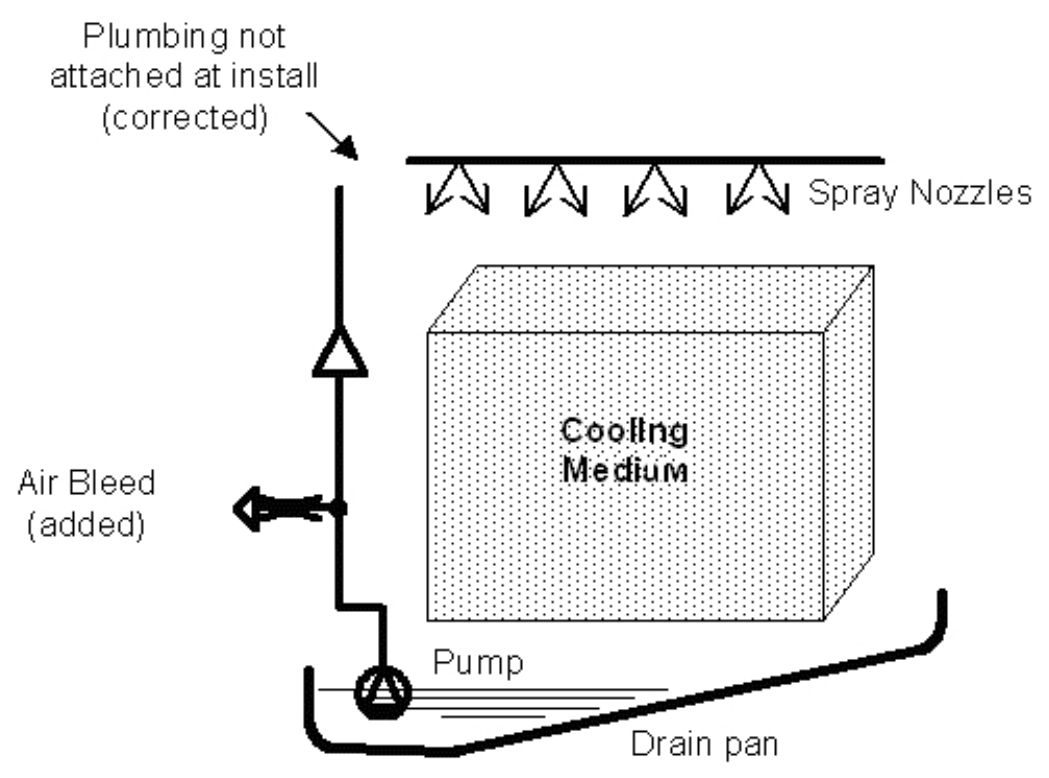

Figure 3-13 Direct evaporative cooler plumb schematic showing problem during construction related to plumbing connection

The direct section of the evaporative cooling unit experienced four separate pump failures. NREL determined that the pumps were not maintaining a prime. Without a satisfactory prime, pumps operated continuously without moving any water and subsequently failed from overheating. A slow air bleed valve was installed downstream of the pump to solve this problem as shown in Figure 3-13.

The evaporative cooling unit's drain pan failed. The on-site fabricator of this drain pan used steel bolts to attach the pan to the evaporative unit. These bolts rusted through and resulted in a substantial leak. Although the mechanical room is outfitted with drains, expansion joints in the floor were located between the pan and the drain. Water leaked to the floor below the mechanical room, causing some damage to the copy room and washrooms. Stainless steel bolts and a replacement seal were used to repair the drain pan. All these failures can be attributed to system design — units such as these should be factory assembled and tested. None of these failures are attributed to the direct/indirect technology, which was successful in the building.

\subsubsection{Conference Room Packaged Unit}

A packaged rooftop HVAC system was used for the conference room. The unit selected by the mechanical engineer has a nominal 4-ton $(14-\mathrm{kW})$ cooling capacity. The loads actually presented to the conference room HVAC system have been calculated to be approximately 1.5 tons $(5.3 \mathrm{~kW})$. The original loads were computed based on a design condition of no overhangs in the space, 40 occupants, and full lighting load. The original design intent for the conference room air conditioner was to use a wall-mounted, mini-split unit for this room with a small condenser located in the east mid-bay. This alternative was rejected by the engineer of the project; note that this is still a viable alternative to install a simple system to meet the loads of the space. Several problems resulted from this oversizing.

The supply fan delivers a nominal flow rate of $1,600 \mathrm{cfm}(755 \mathrm{~L} / \mathrm{s})$ of conditioned air to a room with a floor area of only $400 \mathrm{ft}^{2}\left(37.2 \mathrm{~m}^{2}\right)$ or $4 \mathrm{cfm} / \mathrm{ft}^{2}\left(20 \mathrm{~L} / \mathrm{s} \cdot \mathrm{m}^{2}\right)$. The high supply airflow rate leads to draft problems, with occupants reportedly feeling cold in both heating and cooling modes. NREL subsequently altered the control protocol for heating by changing the HVAC system to operate as a constant temperature and constant volume system that cycles on and off (similar to a home furnace). 
When the system operates in heating mode, the water heating valve is fully opened to increase supply air temperature to avoid the chilling effects of fast-moving air currents. The ideal solution would be to downsize the entire system (compressor and fan) by 50\% (4 tons to 2 tons [14 $\mathrm{kW}$ to $7 \mathrm{~kW}]$ ). This would increase energy savings by increasing part-load factors. The reduction in equipment cycling would increase comfort and potentially reduce maintenance requirements and improve latent load capacity. The oversized unit should be replaced with a small mini-split system. A smaller unit would better serve the needs of the occupants, be more energy efficient, and operate more quietly.

Noise introduced by the packaged system to the space occurs because it is located inside the building, which presents another problem. To address these concerns, a wall was constructed between the conference room and the central core. The wall helped the overall air movement in the building; however, it created problems for the conference room system because it mixes DX cooled air with evaporatively cooled air, causing conference room cold-draft problems to propagate throughout a large part of the building. The draft was caused by a large gap $(0.75 \mathrm{ft}$ by $20 \mathrm{ft}[0.23 \mathrm{~m}$ by $6.1 \mathrm{~m}])$ located between the conference room's ceiling return plenum and the open mid-bay laboratory area. Because the conference room HVAC system uses an open plenum for return air, the system would draw air through the gap, thereby taking "return" air from the east portion of the mid-bay rather than directly from the conference room. The plenum gap was subsequently sealed (during the summer of 1998).

\subsubsection{Air Distribution}

When the building was initially occupied, occupants complained about the "new carpet" smell. LowVOC carpeting was not specified. To address this issue, NREL programmed exhaust fans to operate 24 hours per day to continuously flush the building. After six months, the ventilation system was set to operate as indicated in Section 4.5.

The original intent of the low-bay was to house tabletop experiments for research. During construction, this area was reprogrammed to provide support offices for the laboratory. Carpet and cubicles were added to the low-bay. The air distribution system was designed for open laboratories, not for a space divided by partial walled cubicles. The office cubicles also reduced the impact of the daylighting in the space, as discussed in Section 6.1.

Adequate air distribution in the offices is provided, except for those in the southwest corner. The resulting comfort problem in this area was compounded by the lack of thermal breaks in the windows and the insulation gap in the floor (see Section 3.4 for a discussion of these construction faults). Extending the ductwork to provide additional conditioned air to these spaces improved air distribution and solved some of the comfort problems. The air distribution system would have been designed differently if the intent were to have office furniture in this area.

Building occupants in the open-office area experienced thermal discomfort during the heating season because inadequate mixing caused thermal stratification of room air. NREL determined that the parallel fan-coil mixing boxes were not sufficient to thoroughly mix air within the space. The stratification problem was solved by detecting situations where stratified conditions were present and using this information to control operation of the ceiling fans. Ceiling fans were controlled based on a temperature difference between the zone thermostats and temperature sensors on the ceiling. Fans were energized when the ceiling temperature was greater than the zone thermostats by $7^{\circ} \mathrm{F}\left(4^{\circ} \mathrm{C}\right)$.

\subsubsection{Energy Management System Alterations}

The EMS's proportional, integral, and derivative controllers required additional tuning. The default tuning included a large proportional band with limited reset. The result was a very slow response time for changing supply fan flow rates to varying duct pressures, which was on the order of hours, rather than seconds. The objective was to speed up this response time without causing instability and fan shutdown 
(requiring manual reset). NREL research staff wanted to tune the controller for a faster response time. Consequently, they added an additional control algorithm to vary the static duct pressure depending on load, which resulted in a varying duct pressure set point. The goal was to use the smallest duct pressure to keep at least one VAV box completely open. Smaller duct pressures result in less fan energy. Static pressure is allowed to vary from $0.1 \mathrm{in} .(24.9 \mathrm{~Pa})$ to $3.5 \mathrm{in}$. (871.8 Pa) of pressure. Most of the time, the system operates well below the maximum - typical static pressure is 0.5 in. (124.5 Pa). A possible downside to this algorithm might be stratification during cooling modes. Stratification can be easily mitigated with ceiling fans. Limited stratification during the cooling season has been observed.

NREL also adjusted other EMS controller inputs. Internal fans in the parallel induction fan-coil mixing boxes were always on during the occupied mode. Each VAV box has a preprogrammed control card with algorithms typical of VAV boxes. Various set points can be adjusted on these cards with preset algorithms present in firmware. A control point allowed the operation of the fans only when heating is needed.

Fan performance curves for each variable-speed fan were analyzed to determine characteristics and potentials for saving energy. Operating the controller and fan system while monitoring both controller output and actual current draw provided data on the fan's current draw characteristics.

The VAV supply fan curve (Figure 3-14) is characteristic of an energy-saving, variable-speed drive (VSD). When the fan is operated at reduced speeds, it draws less current and reduces energy requirements. However, the ceiling fans and the heat exchanger fans use an inexpensive controller for part-load operation. Figure 3-15 illustrates the variable-speed performance characteristics of the ceiling fan. However, when the same variable-speed controllers were used with ventilation fans within the air-toair heat exchangers (HEXs), they were shown to be inefficient (Figure 3-16). Because these ventilation fans actually use more energy at lower speeds, NREL disabled the variable-speed control. The fan control is now set at on/off.

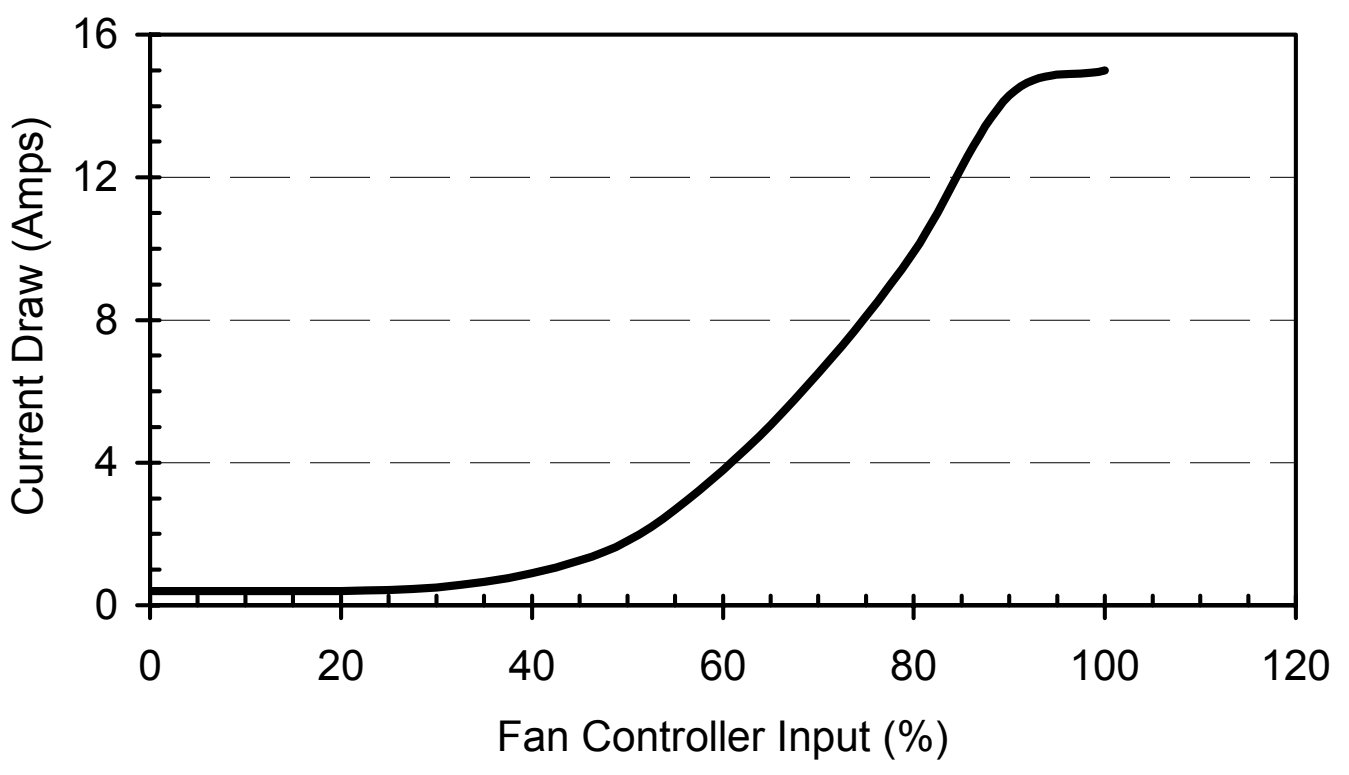

Figure 3-14 Supply fan speed controller input versus current draw 


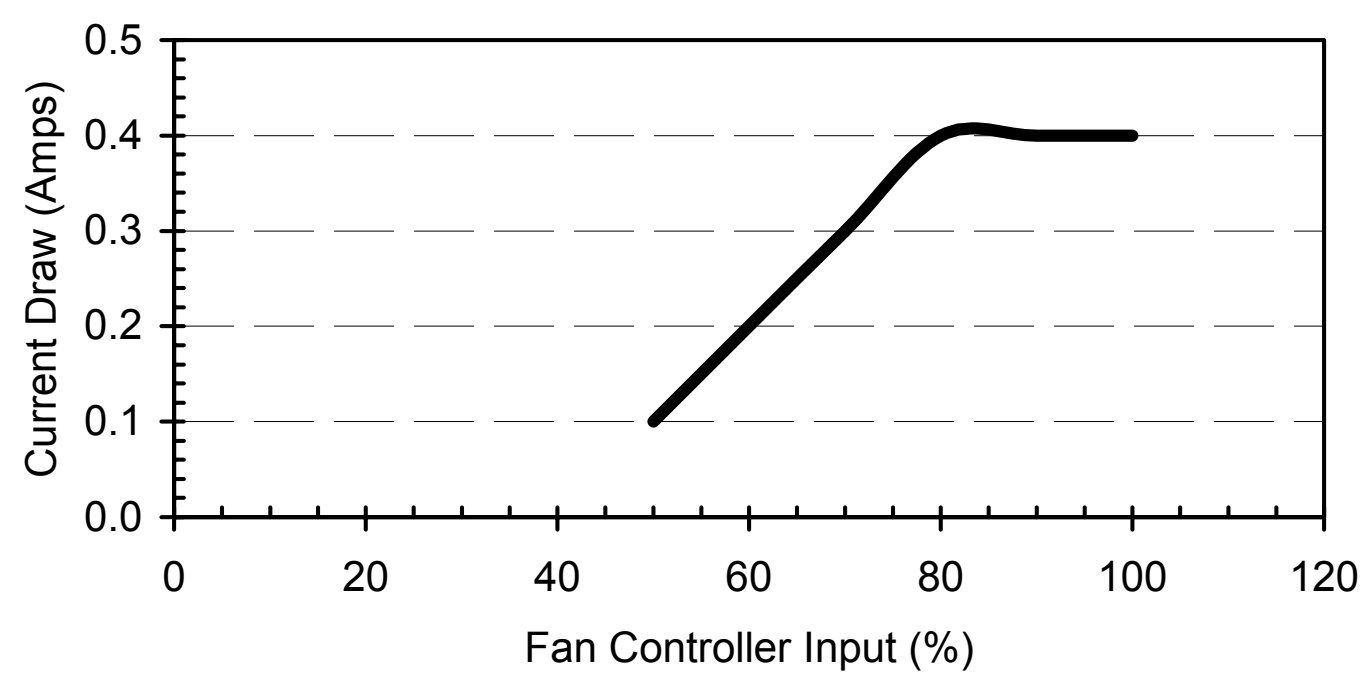

Figure 3-15 Ceiling fan variable-speed controller output versus current draw

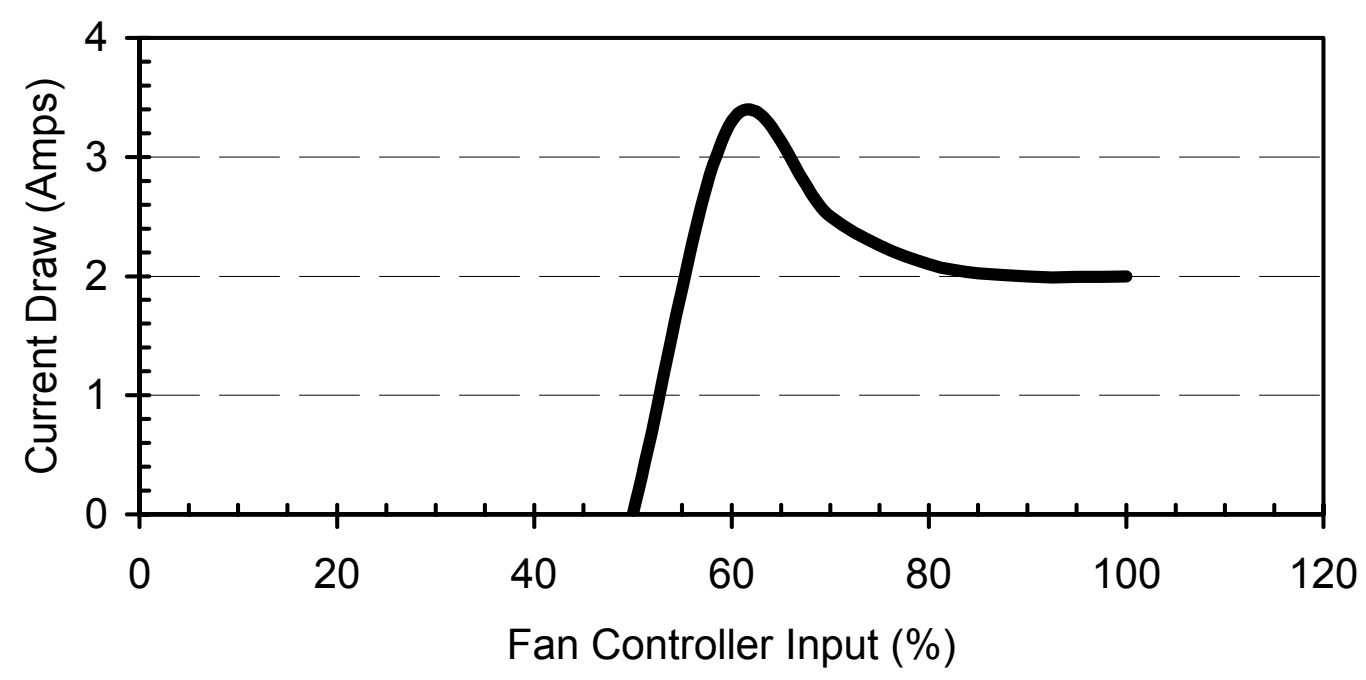

Figure 3-16 Ventilation fan variable-speed controller output versus current draw

NREL programmed the EMS to control the conference room packaged air-handler unit independently from the rest of the building. The controller monitors the room's occupancy status and the ventilation fan supplies fresh, outdoor air to the space when the room is occupied. If the room remains occupied for a period of 3 minutes, the temperature dead band values are reduced from $7^{\circ} \mathrm{F}$ to $2^{\circ} \mathrm{F}\left(4^{\circ} \mathrm{C}\right.$ to $\left.1^{\circ} \mathrm{C}\right)$. The set point can be varied, but is usually $72^{\circ} \mathrm{F}\left(22^{\circ} \mathrm{C}\right)$. The result is a typical setback/setup of $63^{\circ} \mathrm{F} / 79^{\circ} \mathrm{F}$ $\left(17^{\circ} \mathrm{C} / 26^{\circ} \mathrm{C}\right)$. The normal occupied temperature range for the room is $70^{\circ} \mathrm{F}$ to $74^{\circ} \mathrm{F}\left(21^{\circ} \mathrm{C}\right.$ to $\left.23^{\circ} \mathrm{C}\right)$. After an unoccupied period of three minutes, the ventilation fan stops, and the temperature dead band returns to its unoccupied setback/setup values. Because the heating coil, the fan, and evaporator are significantly oversized for the room, this control strategy can recover quickly between unoccupied and occupied periods. 
The conference room HVAC system incorporates a heat recovery ventilator. The heat recovery unit has a rated effectiveness of 70\%. Duct layout for this system was not properly designed. (See Section 4.6.) Instead of exhausting air to the outside environment, it is released into the mid-bay area, and provides no real energy savings based on an energy balance of the entire building. Excessive energy is consumed because the exhaust side of the heat recovery unit requires a fan. NREL disconnected the exhaust portion to alleviate this problem; however, this solution does not fix the ventilation heat exchanger problem. The proper, but more expensive, solution would be to alter the ductwork and deliver the scavenger exhaust air to the outdoor environment.

Additionally, the ventilation airflow from the conference room heat recovery ventilator is not sufficient to provide an economizer cycle, resulting in the air-conditioner running year round. Economizer modes should be designed into ventilation systems with heat exchanges to maximize the benefit of these systems.

\subsection{Summary of Whole-Building Design Process}

The whole-building design process requires the project team — which includes the architect, systems engineers (lighting, electrical, and mechanical), energy consultants, and the building's owner and occupants - to form a strong commitment to work together to meet the aggressive performance goals set for the building. Each member is encouraged to find solutions and offer suggestions that benefit other disciplines, the whole process, and ultimately the building design.

The team's combined effort to reduce building energy consumption begins at the conceptual design phase and continues through the design development phase. For successful realization of low-energy buildings, the project team must commit to cost-effective energy minimization as a high priority design goal. Once the project team is committed to energy cost minimization as a design goal, the whole-building design process can be used to provide the team with information for good decision making and trade-off analysis. During the construction and commissioning phases, the design team cooperatively ensures that integrated architectural features (e.g., daylighting and managed solar gains) and engineered building systems are built and function as originally designed. Once the building is occupied, the team supports the building operators as they learn how the building is intended to operate. Finally, the design team is responsible for understanding how the building actually operates over the long-term, so that the building, and future buildings, can realize energy savings over the years.

Direct experience provided through designing and constructing the TTF led to a method of organizing a whole-building design process into the nine steps listed in Table 3-5 (Hayter et al. 2000). Although the TTF design process did not exactly follow these steps, Table 3-5 includes strategies based on lessons learned from the TTF design process. 
Table 3-5 Nine-Step Process for Designing and Constructing Energy-Efficient Buildings

\begin{tabular}{|c|c|}
\hline Predesign & $\begin{array}{l}\text { 1. Create a base-case building model to quantify base-case energy use } \\
\text { and costs. The base-case building is solar neutral (equal glazing areas } \\
\text { on all wall orientations) and meets the requirements of applicable energy } \\
\text { efficiency codes such as ASHRAE Standards } 90.1 \text { (ASHRAE 1989.) } \\
\text { 2. Complete a parametric analysis to determine sensitivities to specific load } \\
\text { components. Sequentially eliminate loads from the base-case building, } \\
\text { such as conductive losses, lighting loads, solar gains, and plug loads. } \\
\text { 3. Develop preliminary design solutions. The design team brainstorms } \\
\text { possible solutions, which may include strategies to reduce lighting and } \\
\text { cooling loads by incorporating daylighting or to meet heating loads with } \\
\text { passive solar heating. }\end{array}$ \\
\hline $\begin{array}{l}\text { Schematic } \\
\text { Design }\end{array}$ & $\begin{array}{l}\text { 4. Incorporate preliminary design solutions into a computer model of the } \\
\text { proposed building design. Energy impact and cost effectiveness of each } \\
\text { variant are determined by comparing the calculated energy performance } \\
\text { with the original base-case building and to the other variants. Variants } \\
\text { with the most favorable results should be incorporated into the building } \\
\text { design. } \\
\text { 5. Prepare preliminary set of construction drawings. These drawings are } \\
\text { based on the decisions made in Step 4. Architectural decisions made } \\
\text { during the schematic design can have the greatest impact on the long- } \\
\text { term building energy performance. }\end{array}$ \\
\hline $\begin{array}{l}\text { Design } \\
\text { Development }\end{array}$ & $\begin{array}{l}\text { 6. Identify the HVAC system that will meet the predicted loads. The HVAC } \\
\text { system should complement the building architecture and exploit the } \\
\text { specific climactic characteristics of the site for maximum efficiency. } \\
\text { Often, the HVAC system capacity is much less than in a typical building. }\end{array}$ \\
\hline $\begin{array}{l}\text { Construction } \\
\text { Documents and } \\
\text { Bid }\end{array}$ & $\begin{array}{l}\text { 7. Finalize plans and specifications. Ensure that the building plans are } \\
\text { properly detailed and that the specifications are accurate. The final } \\
\text { design simulation should incorporate all cost-effective features. Savings } \\
\text { exceeding } 50 \% \text { from a base-case building are frequently possible with } \\
\text { this approach. }\end{array}$ \\
\hline Construction & $\begin{array}{l}\text { 8. Rerun simulations before design changes are made during construction. } \\
\text { Verify that changes will not adversely affect the building's energy } \\
\text { performance. }\end{array}$ \\
\hline Occupancy & $\begin{array}{l}\text { 9. Commission all equipment and controls. Educate building operators. } \\
\text { Only a properly commissioned building will meet the original energy } \\
\text { efficiency design goals. Building operators must understand how to } \\
\text { properly operate the building to maximize its performance. }\end{array}$ \\
\hline
\end{tabular}




\section{TTF Building Description}

\subsection{Section Overview}

This section presents the description of the final building design, including results of the design process, changes made during and after construction, and modifications made during the commissioning process. Photographs of actual building and components are used to document the design.

Figure 4-1 shows an axonometric of the building highlighting some of the significant design features that contribute to the energy performance of the building. Table 4-1 summarizes the design features of the building.

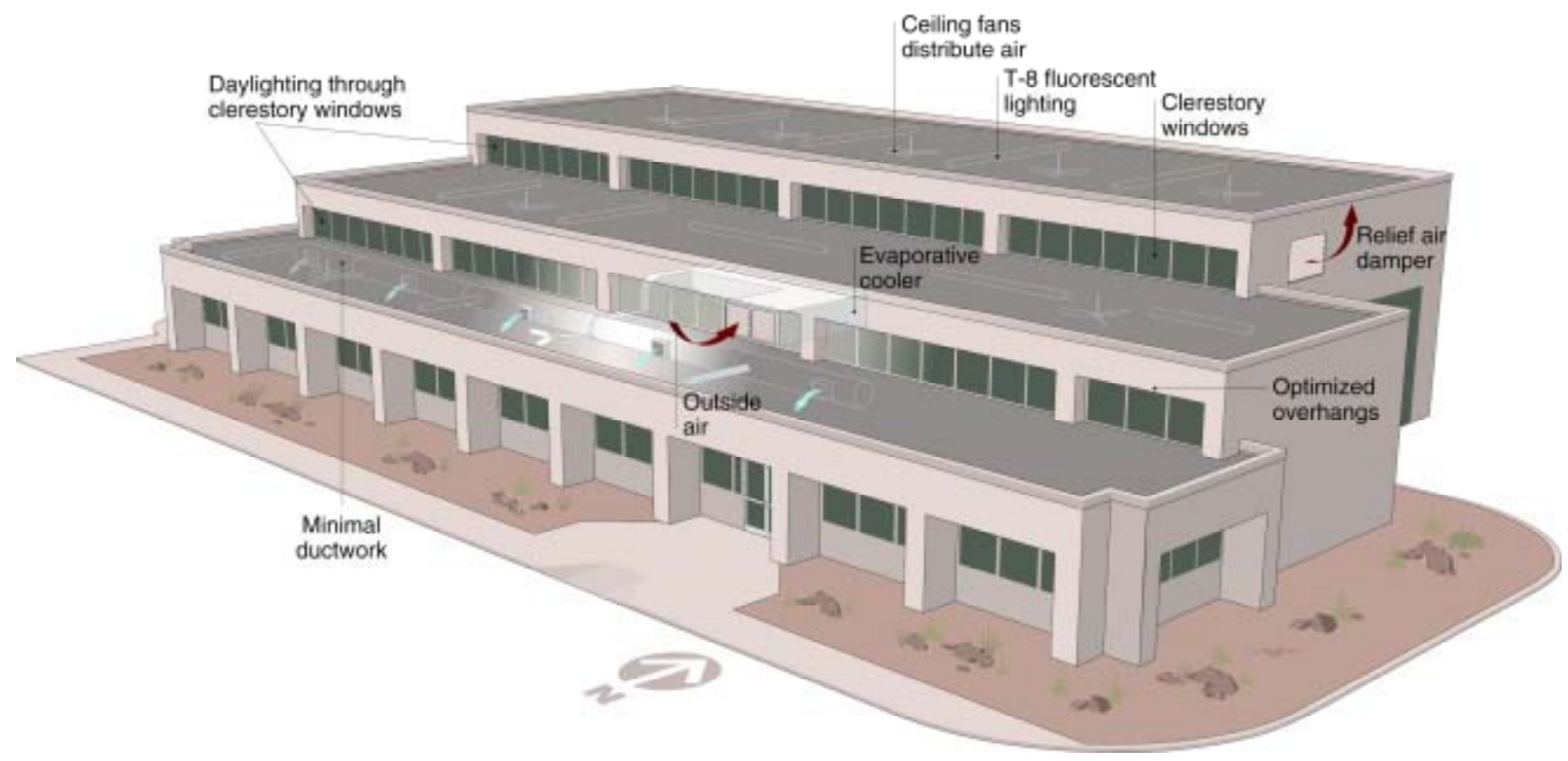

Figure 4-1 Axonometric drawing of the TTF final design 
Table 4-1 TTF Design Summary

\begin{tabular}{|c|c|c|}
\hline Energy Feature & Characteristics & Values \\
\hline Building Orientation & Long east-west axis & Aspect ratio $=1.75$ \\
\hline $\begin{array}{l}\text { Fenestration } \\
\text { Orientation }\end{array}$ & $\begin{array}{l}88 \% \text { south-facing } \\
\text { View-glass (south side) } \\
\text { Clerestory (mid-bay) } \\
\text { Clerestory (high-bay) } \\
4 \% \text { east-facing } \\
1 \% \text { north-facing } \\
4 \% \text { west-facing }\end{array}$ & $\begin{array}{l}1,134 \mathrm{ft}^{2}\left(105.4 \mathrm{~m}^{2}\right) \\
492 \mathrm{ft}^{2}\left(45.7 \mathrm{~m}^{2}\right) \\
321 \mathrm{ft}^{2}\left(29.8 \mathrm{~m}^{2}\right) \\
321 \mathrm{ft}^{2}\left(29.8 \mathrm{~m}^{2}\right) \\
56 \mathrm{ft}^{2}\left(5.2 \mathrm{~m}^{2}\right) \\
38 \mathrm{ft}^{2}\left(3.5 \mathrm{~m}^{2}\right) \\
56 \mathrm{ft}^{2}\left(5.2 \mathrm{~m}^{2}\right)\end{array}$ \\
\hline Passive solar design & $\begin{array}{l}\text { Vertical south-facing clerestory } \\
\text { windows with high solar gain } \\
\text { exposed thermal mass } \\
\text { with concrete floor } \\
\text { and north wall }\end{array}$ & $\begin{array}{l}\text { SHGC }=0.65 \\
\text { Thickness }=6 \text { in. }(15 \mathrm{~cm}) \\
\text { Thickness }=8 \text { in. }(20 \mathrm{~cm})\end{array}$ \\
\hline Overhangs & $\begin{array}{l}\text { Simulations used to determine size } \\
\text { and geometry were based on } \\
\text { minimizing annual energy use } \\
\text { (Figure } 3-8 \text { shows the definition of } \\
\text { overhang and offset ratios.) }\end{array}$ & $\begin{array}{l}\text { View-glazing: overhang ratio }=0.98 \\
\text { offset ratio }=0.28 \\
\text { Clerestories: overhang ratio }=0.43 \\
\text { offset ratio }=0.23 \text { (Figure } 4-6 \text { shows } \\
\text { overhang and offset ratios) }\end{array}$ \\
\hline $\begin{array}{l}\text { Building Thermal } \\
\text { Envelope }\end{array}$ & $\begin{array}{l}\text { View-glazing (south side) } \\
\text { Clerestory glazing } \\
\text { Slab perimeter } \\
\text { North wall (exterior foam) } \\
\text { Other walls } \\
\text { Roof } \\
\text { Low infiltration }\end{array}$ & $\begin{array}{l}\mathrm{U}-0.42 \mathrm{Btu} / \mathrm{h} \cdot \mathrm{ft}^{2} \cdot{ }^{\circ} \mathrm{F}\left(2.4 \mathrm{~W} / \mathrm{m}^{2} \cdot \mathrm{K}\right) \\
\mathrm{U}-0.45 \mathrm{Btu} / \mathrm{h} \cdot \mathrm{ft}^{2} \cdot{ }^{\circ} \mathrm{F}\left(2.6 \mathrm{~W} / \mathrm{m}^{2} \cdot \mathrm{K}\right) \\
\mathrm{R}-10 \mathrm{~h} \cdot \mathrm{ft}^{2} \cdot{ }^{\circ} \mathrm{F} / \mathrm{Btu}\left(1.8 \mathrm{~m}^{2} \cdot \mathrm{K} / \mathrm{W}\right) \\
\mathrm{R}-10 \mathrm{~h} \cdot \mathrm{ft}^{2} \cdot{ }^{\circ} \mathrm{F} / \mathrm{Btu}\left(1.8 \mathrm{~m}^{2} \cdot \mathrm{K} / \mathrm{W}\right) \\
\mathrm{R}-23 \mathrm{~h} \cdot \mathrm{ft}^{2} \cdot{ }^{\circ} \mathrm{F} / \mathrm{Btu}\left(4.0 \mathrm{~m}^{2} \cdot \mathrm{K} / \mathrm{W}\right) \\
\mathrm{R}-23 \mathrm{~h} \cdot \mathrm{ft}^{2} \cdot{ }^{\circ} \mathrm{F} / \mathrm{Btu}\left(4.0 \mathrm{~m}^{2} \cdot \mathrm{K} / \mathrm{W}\right) \\
0.1 \mathrm{ACH}(\text { measured by tracer gas study) }\end{array}$ \\
\hline Electric Lighting & $\begin{array}{l}\text { T-8 fluorescent / electronic ballast } \\
\text { Compact fluorescent } \\
\text { LED emergency exit signs } \\
\text { Emergency lighting: low-voltage wall } \\
\text { packs with integral batteries } \\
\text { No emergency ballasts installed } \\
\text { Exterior lighting low-pressure sodium } \\
\text { (LPS) wall packs }\end{array}$ & $\begin{array}{l}\text { Installed capacities } \\
\text { T-8: } 7060 \mathrm{~W} \\
\text { CFL: } 224 \mathrm{~W} \\
\text { LPS: } 433 \mathrm{~W} \\
\text { Exit signs: } 9 \mathrm{~W} \\
\text { Emergency: } 216 \mathrm{~W}\end{array}$ \\
\hline Daylighting & $\begin{array}{l}\text { Stair-stepped design } \\
\text { View-glass (gray tint) } \\
\text { Clerestory }\end{array}$ & $\begin{array}{l}\text { Visual transmittance: } 38 \% \\
\text { Visual transmittance: } 72 \%\end{array}$ \\
\hline HVAC & $\begin{array}{l}\text { Temperature setback } \\
\text { Temperature setup } \\
\text { Low-pressure air distribution } \\
\text { Conference room package } \\
\text { single-zone condenser placed } \\
\text { indoors to take advantage of } \\
\text { evaporative cooling } \\
\text { EMS-integrated controls } \\
\text { Variable air volume system } \\
\text { Indirect-direct evaporative cooling } \\
\text { Economizer } \\
\text { Parallel fan coil mixing boxes } \\
\text { Heat recovery on ventilation air } \\
\text { Ceiling fan air mixing }\end{array}$ & $\begin{array}{l}55^{\circ} \mathrm{F}\left(12.8^{\circ} \mathrm{C}\right) \\
85^{\circ} \mathrm{F}\left(29.4^{\circ} \mathrm{C}\right)\end{array}$ \\
\hline
\end{tabular}




\subsection{Site and Building Plan}

The design team integrated the building into the side of South Table Mountain at NREL in Golden, Colorado. A climate-sensitive design ensured that the building worked with the Golden, Colorado climate.

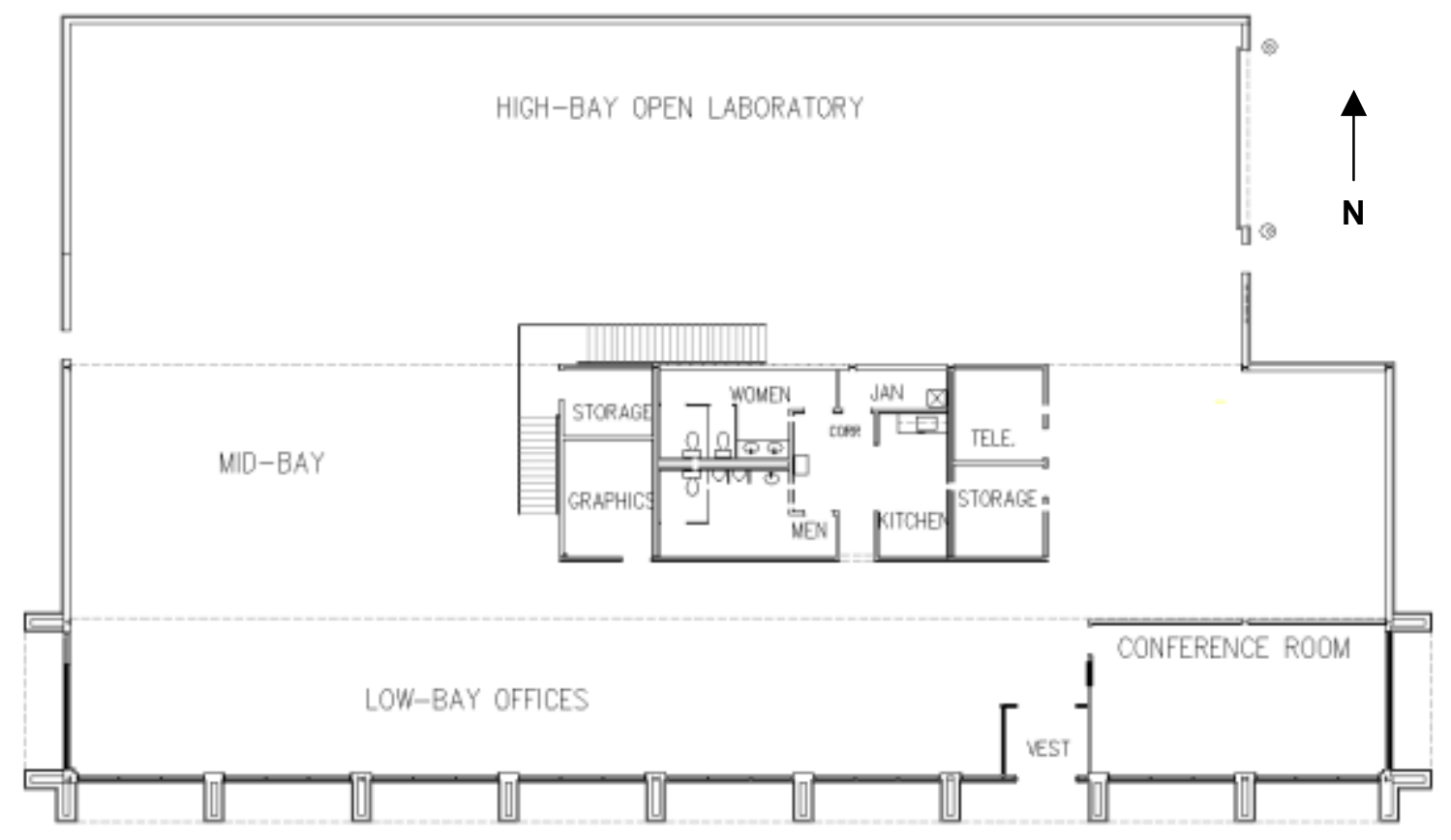

Figure 4-2 As-built floor plan for the Thermal Test Facility

Figure 4-2 depicts the TTF's final design floor plan. The design team located the mechanical room on the mezzanine level above the service core of the building. Locating the mechanical room in this area allowed the mechanical system to be centrally located for air distribution as well as within the thermal envelope of the building. In addition, replacement equipment could be installed through an opening to the high-bay. Restrooms, storage areas, and a small kitchen were moved to the central service core. The final floor plan placed laboratory support offices in the low-bay area and it designated the mid- and highbays for experiments.

Because NREL had the TTF built into the side of South Table Mountain, the north wall of the building was designed to serve as a retaining wall for the mountain slope. This design change from the initial conceptual design allowed people to park on the south side of the building for easy access. In addition, the site plan allowed for a long east-west axis to the building to enhance the solar gains and daylighting.

The gross conditioned floor area of the TTF is $10,000 \mathrm{ft}^{2}\left(929 \mathrm{~m}^{2}\right)$. This area was measured from the inside surface of the exterior walls and includes the areas of interior columns and partitions, as well as the vestibule. The mechanical mezzanine was considered a second story, and its area was included in the total. The entire interior was designated as conditioned space. 
Many passive solar features were integrated into the TTF's final design. The design team took advantage of Colorado's sunny climate through the careful selection, orientation, and placement of windows and clerestories, as shown in Figure 4-3 and Figure 4-4 (NREL 2004). Traditionally, passive solar heating is not beneficial for commercial buildings because they have abundant internal heat gains from large numbers of people, lights, and equipment, and, except for morning warm-up, require cooling most of the year. However, this convention breaks down for daylit buildings in which the electric lights no longer provide significant heating because they mostly are turned off during the day. This analysis was shown during the design phase in Section 3.3.

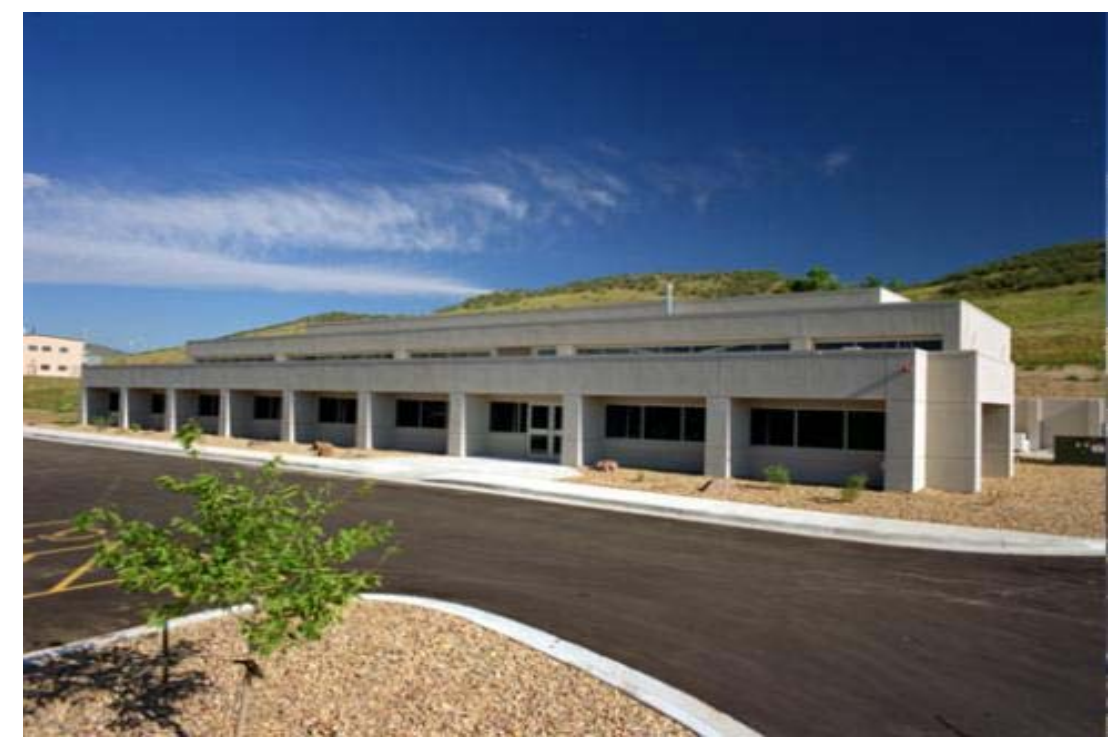

Figure 4-3 Photo of the front of the TTF from the southeast

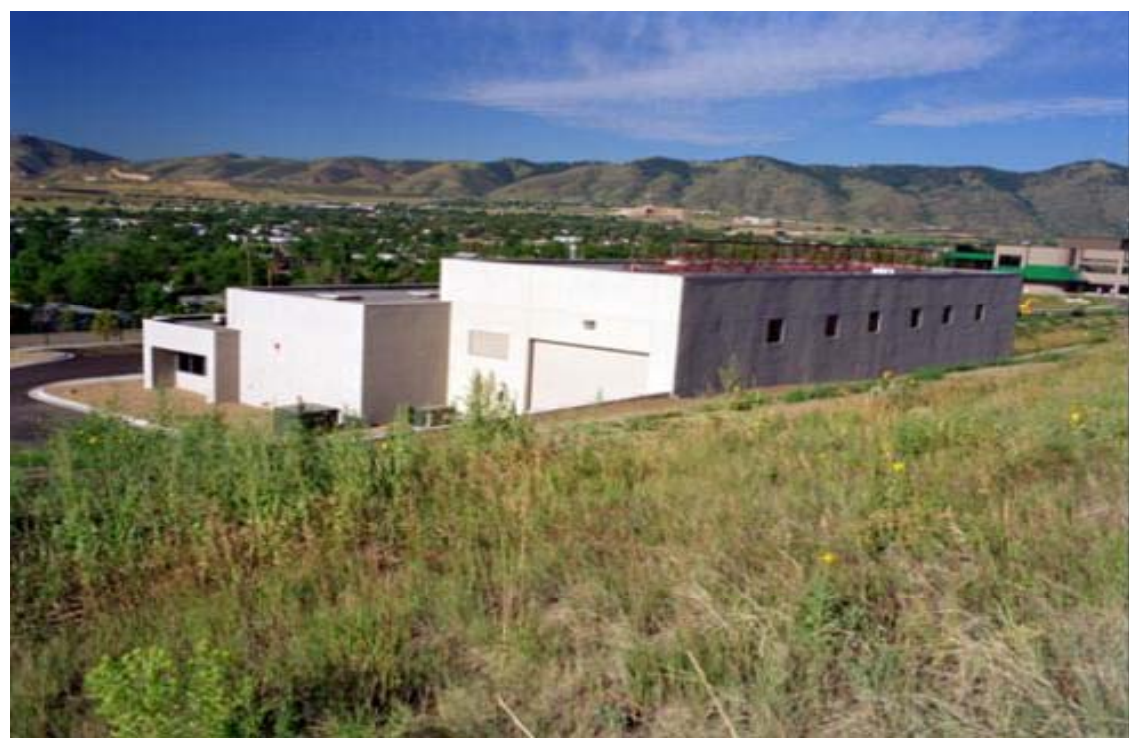

Figure 4-4 Photo of the TTF from the northeast 
The passive solar and daylighting design of the building incorporates $88 \%\left(1,134-\mathrm{ft}^{2}\left[105.4-\mathrm{m}^{2}\right]\right)$ of its total window area as a single row of view-glass $\left(492 \mathrm{ft}^{2}\left[45.7 \mathrm{~m}^{2}\right]\right)$ and two rows of clerestories $\left(642 \mathrm{ft}^{2}\right.$ $\left.\left[59.6 \mathrm{~m}^{2}\right]\right)$ along the southern facade. An additional $8 \%$ of the total view-glass area exists on the east (56 $\left.\mathrm{ft}^{2}\left[5.2 \mathrm{~m}^{2}\right]\right)$ and west $\left(56 \mathrm{ft}^{2}\left[5.2 \mathrm{~m}^{2}\right]\right)$ facades; the remaining $1 \%$ is positioned on the north wall $\left(38 \mathrm{ft}^{2}\right.$ $\left.\left[3.5 \mathrm{~m}^{2}\right]\right)$.

NREL engineered the building to provide passive solar gain during the winter months and minimize this gain during the summer months. The selected glass type allows solar energy to enter the building for passive heating energy. South-facing clerestory windows have a high SHGC of 0.68 (shading coefficient of 0.76); all others have a lower SHGC of 0.45 (shading coefficient of 0.51). The ground-level windows were designed for viewing and are larger than needed from an energy perspective. To avoid overheating and glare from too much direct gain through these windows during the winter, the view windows have a lower shading coefficient than the clerestory windows. All windows were engineered with a low-e coating to reduce thermal conductance of the glazing. Engineered overhangs were designed to block direct solar radiation during the warm summer months when sun angles are high.

Figure 4-5 illustrates how these overhangs avoid impeding direct solar radiation during the winter months when sun angles are much lower. Fins on the south-facing, ground-level windows were incorporated for aesthetic reasons, rather than as part of the passive solar design. They provide some solar gain relief for the east and west facades of the building as well as some limited glare control on the south facade.

Overhang ratios for the view glass and clerestories are shown in Figure 4-6. NREL engineered the northfacing window areas to augment the clerestories. The net result is bi-directional lighting that minimizes the heat transfer through the glazing.

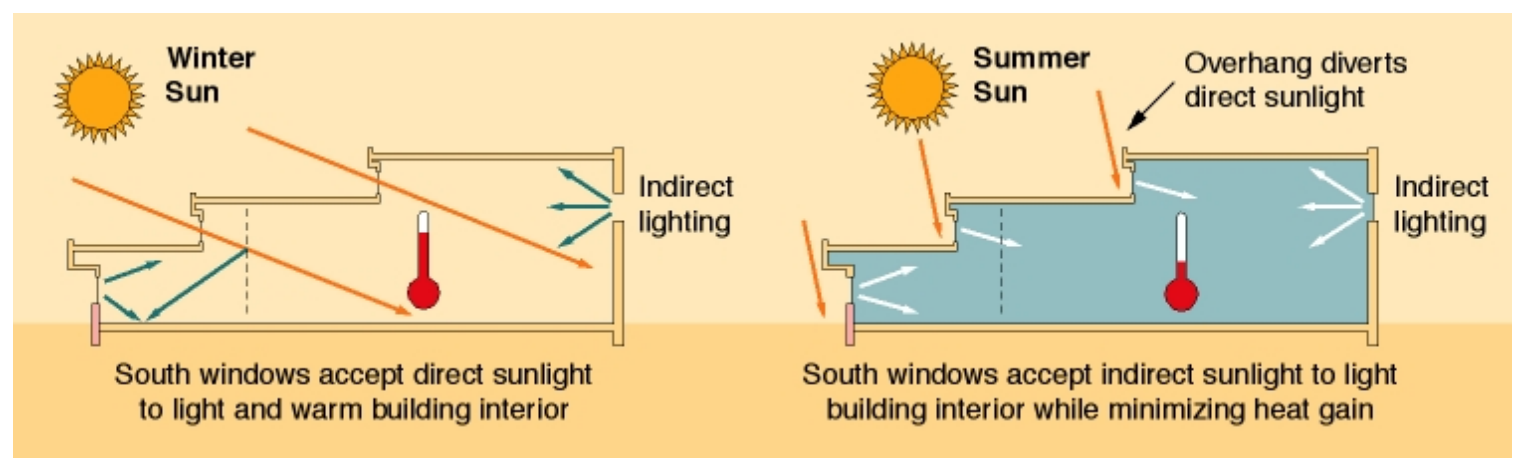

Figure 4-5 Managing solar gains with overhangs 

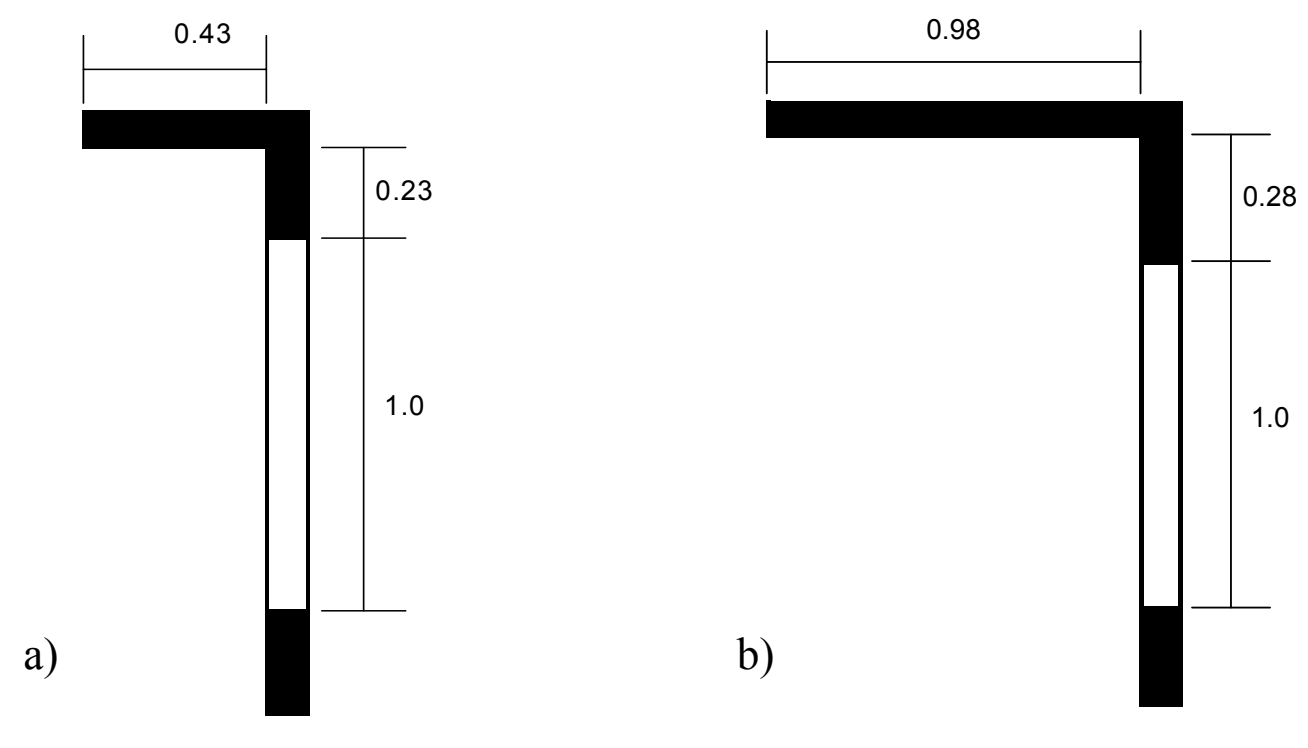

Figure 4-6 Overhang ratios for clerestories (a) and view glass (b)

\subsection{Building Envelope}

The TTF's passive solar design includes a well-insulated thermal envelope. Although not a prominent design feature, thermal mass in the floor and north wall does help to minimize temperature swings. In addition, the envelope of the building is tight with very little infiltration ( $0.1 \mathrm{ACH}$ measured). The design team added the massive north wall for structural reasons and not energy reasons, although there is a small energy benefit.

Opaque envelope components for the TTF were selected to be highly insulating and to expose thermal mass to the interior. The TTF's floor is a 6-in. $(15.2-\mathrm{cm})$ concrete slab with $4 \mathrm{ft}(1.2 \mathrm{~m})$ of perimeter insulation providing an R-value of $10 \mathrm{~h} \cdot \mathrm{ft}^{2} \cdot{ }^{\circ} \mathrm{F} / \mathrm{Btu}\left(1.8 \mathrm{~m}^{2} \cdot \mathrm{K} / \mathrm{W}\right)$. A problem area is the 6-in. (15.2-cm) thermal bridge where the slab is attached to the stem walls. See Section 5.4.1.2 for a discussion of this issue.

The north wall is an 8 -in. $(20.3-\mathrm{cm})$ tilt-up concrete slab with 2 in. $(5 \mathrm{~cm})$ of exterior rigid polystyrene foam providing a total R-value of $5 \mathrm{~h} \cdot \mathrm{ft}^{2} \cdot{ }^{\circ} \mathrm{F} / \mathrm{Btu}\left(0.9 \mathrm{~m}^{2} \cdot \mathrm{K} / \mathrm{W}\right)$. The east, west, and south walls use 6 -in. $(15.2-\mathrm{cm})$ steel studs with batt insulation positioned between the studs. The insulation has a rated Rvalue of $19 \mathrm{~h} \cdot \mathrm{ft}^{2} \cdot{ }^{\circ} \mathrm{F} / \mathrm{Btu}\left(3.3 \mathrm{~m}^{2} \cdot \mathrm{K} / \mathrm{W}\right)$. In addition, 1-in. $(2.5-\mathrm{cm})$ expanded polystyrene was placed over the entire exterior surface of the east, west, and south walls, providing an additional R-value of $4 \mathrm{~h} \cdot \mathrm{ft}^{2} \cdot{ }^{\circ} \mathrm{F} / \mathrm{Btu}\left(0.7 \mathrm{~m}^{2} \cdot \mathrm{K} / \mathrm{W}\right)$. The resulting total R-value of these walls is $23 \mathrm{~h} \cdot \mathrm{ft}^{2} \cdot{ }^{\circ} \mathrm{F} / \mathrm{Btu}\left(4.0 \mathrm{~m}^{2} \cdot \mathrm{K} / \mathrm{W}\right)$. The exterior is finished with an exterior insulation and finish system (EIFS). The roof is constructed with metal decking on steel supports with a built-up roof that uses a 3-in. $(7.6-\mathrm{cm})$ polyisocianurate covering that provides an R-value of $23 \mathrm{~h} \cdot \mathrm{ft}^{2} \cdot{ }^{\circ} \mathrm{F} / \mathrm{Btu}\left(4.0 \mathrm{~m}^{2} \cdot \mathrm{K} / \mathrm{W}\right)$. NREL simulated the addition of a reflective (white) roof membrane to the building, but found that it was not cost-effective when used with this level of thermal insulation. Instead, a 6-ft $(1.8-\mathrm{m})$ band of reflective membrane was used underneath the clerestory windows to increase the amount of daylight into the space.

Windows for the TTF were selected for low thermal conductance and tuned for appropriate optical properties. NREL specified thermally broken aluminum frames with double-pane insulated glazing units (IGUs) for the office area and conference room. Note that the contractor did not install the thermally broken frames. The specified IGUs consisted of a 1/4-in. (6-mm) gray tinted outer glazing, a $1 / 2$-in. (13- 
$\mathrm{mm}$ ) airspace, and a low-e coated, 1/4-in. (6-mm) clear inner glazing layer. Low-e coatings were located on surface \#3 and were of the pyrolitic type (Pilkington 1995). The whole-window U-factor is 0.42 $\mathrm{Btu} / \mathrm{h} \cdot \mathrm{ft}^{2} \cdot{ }^{\circ} \mathrm{F}\left(2.4 \mathrm{~W} / \mathrm{m}^{2} \cdot \mathrm{K}\right)$ and the SHGC is 0.44 .

Different windows were selected for the clerestory locations that provide high light transmission. NREL specified that these clerestory windows be thermally broken aluminum frames with clear glazing layers. The specified IGUs were a 1/4-in. (6-mm) clear outer glazing, a 1/2-in. (13-mm) airspace, and a low-e coated, $1 / 4-$ in. (6-mm) clear inner glazing layer. For these clerestory windows, the whole window U-factor is $0.45 \mathrm{Btu} / \mathrm{h} \cdot \mathrm{ft}^{2} \cdot{ }^{\circ} \mathrm{F}\left(2.6 \mathrm{~W} / \mathrm{m}^{2} \cdot \mathrm{K}\right)$, and the SHGC is 0.65 . Again, thermally broken frames were not installed.

\subsection{Lighting Systems}

A combination of electric lighting and daylight illuminate the TTF. The amount of electric light provided at any one time depends on occupancy and the availability of daylight. The building's clerestory or stairstepped design is an integral part of the lighting plan because the design allowed for more use of natural light. Daylight enters the building through a row of windows lining the south facade of the open-office areas and two additional rows of clerestory windows in the mid- and high-bays. To provide some bidirectional light, six small 2.5 -ft by $2.5-\mathrm{ft}(0.76-\mathrm{m}$ by $0.76-\mathrm{m})$ north windows are located in the high-bay. In addition, the service core south wall allows for reflection of mid-bay clerestory light into the office (low-bay) area.

All windows were specified to maximize daylighting transmittance. NREL selected clerestory windows with a high visible transmittance of $72 \%$. View-glass windows in the open-office area and conference room were chosen with a slightly gray tint, which produces a visible transmittance of $38 \%$, to reduce glare issues associated with incoming daylight.

Lighting zones were selected based on occupancy and daylighting. Zones were defined to be parallel to the fenestration. Zones are defined as low-bay east, low-bay west, mid-bay east, mid-bay west, high-bay east, and high-bay west, and the conference room. Additional zones with no daylighting are the men's restroom, the women's restroom, the hallway, and the kitchenette and closets. Lighting zones are shown in the lighting plan in Figure 4-7. It should be noted that portions of these spaces could have been daylit with opaque glass on the interior south wall opening to the hallway. 


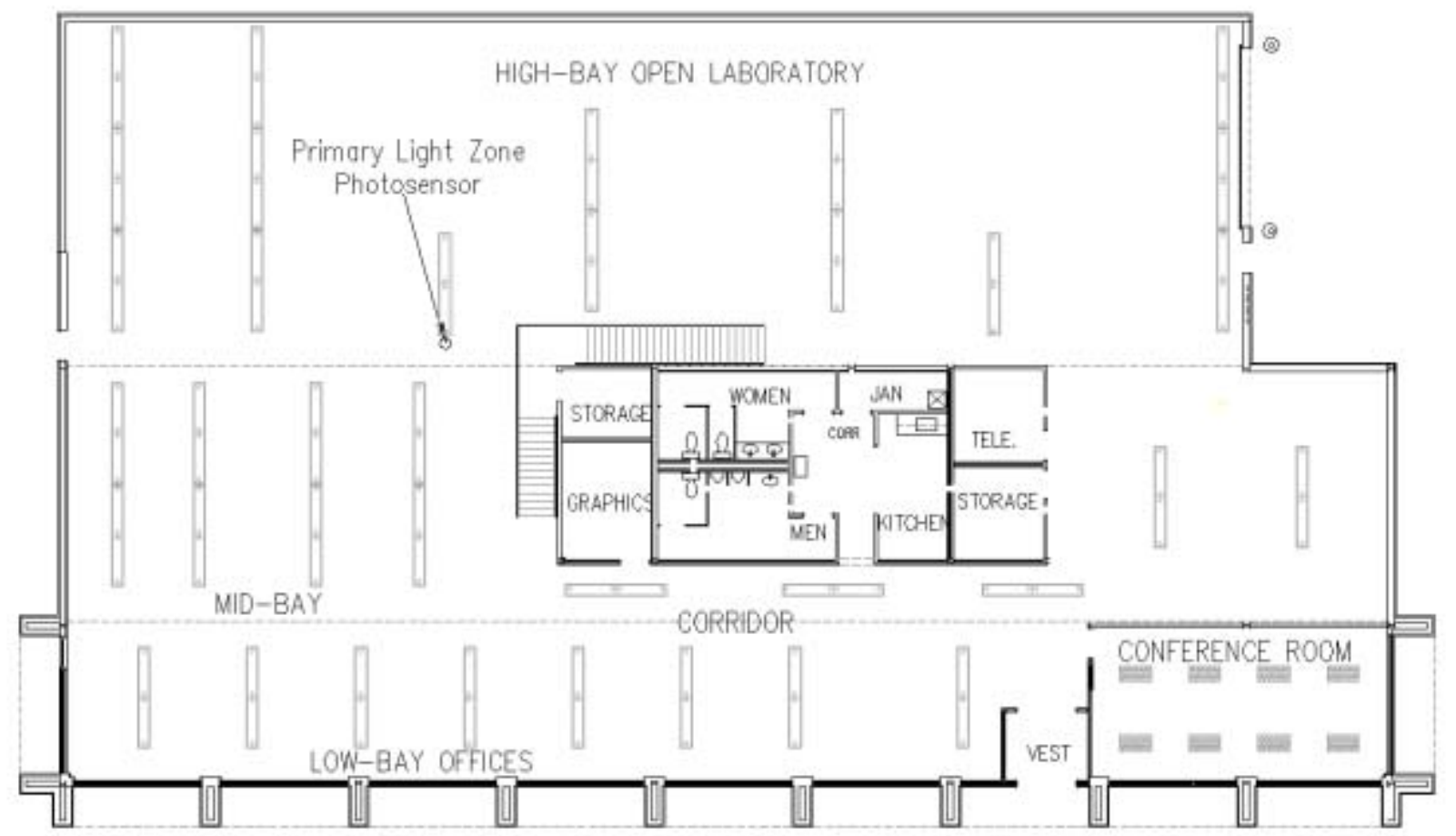

Figure 4-7 Lighting plan

Nondaylit zones use infrared sensors to turn on the lights. When occupancy is not detected, the sensors turn off the lights. The exception to this is the conference room that uses a dual technology sensor (infrared combined with ultrasonic). The conference room has dimming fixtures on a manual switch and no daylighting control.

Daylit zones use ceiling-mounted occupancy sensors, as shown in Figure 4-9. These sensors are connected to the EMS. In addition, a single analog photocell, located in the clerestory of the high-bay as shown in Figure 4-8, provides lighting levels to the EMS. The EMS uses the lighting level information to turn the lights on or off. At the time of design, dimming technologies were not available at a reasonable cost. Each zone was calibrated against the single photocell to provide set points for controlling the lights. When light levels drop below the threshold, lights turn on. The lights will turn off only if the minimum light level for each zone has been met for a certain time. This prevents short cycling on variably cloudy days. When motion is sensed, a zone is enabled to come on. After a programmed time delay of no motion, lights are turned off. Note that the lights will come on only if the light level is below the set point and if there is motion. The EMS-based lighting controls provide the ability to change delay times and set points without accessing the sensor directly. It was important that the lighting controls be easily manipulated because of the ceiling heights and accessibility of the sensors.

The exception to this control scheme is the hallway located between the offices and service core. This hallway is served by an integrated motion and daylight sensor that provides security lighting for the building; its lights are not connected to the EMS. When the building is not occupied, no lighting is on. As soon as the front door is moved, the security lighting is triggered on, unless there is ample daylighting. It is important to note that security lighting is off when daylighting is available. 


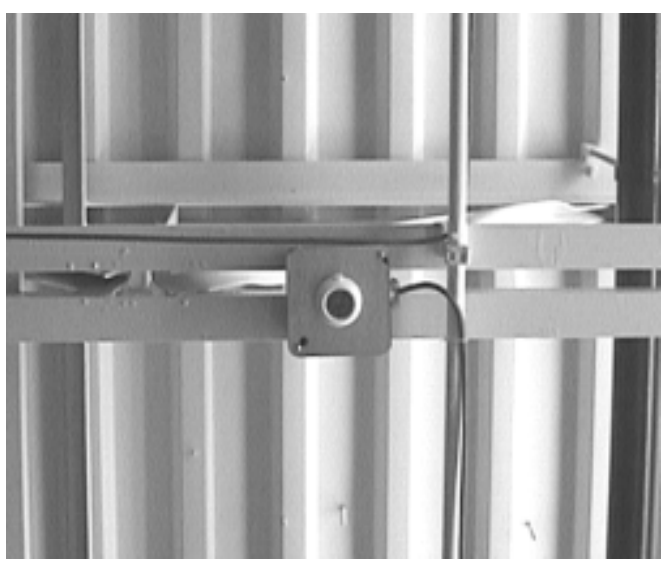

Figure 4-8 Sensor used by the EMS to control electric lighting based on availability of natural daylight

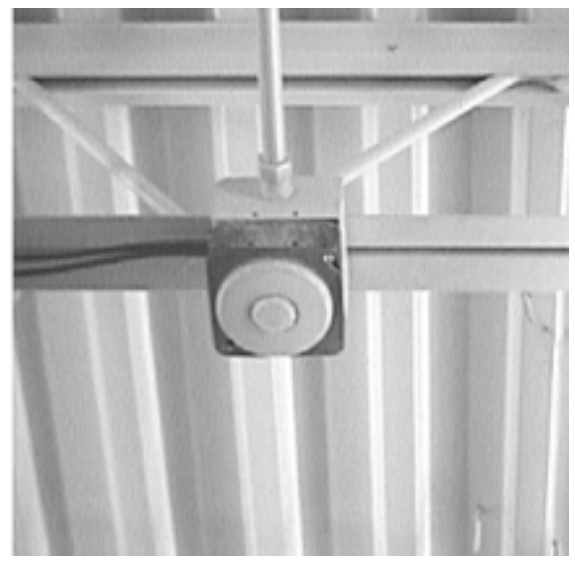

Figure 4-9 EMS-integrated occupancy sensor

Figure 4-10 shows the luminaires selected for area lighting; Table 4-2 lists the installed capacities as well as the lighting power density (LPD). These fixtures use T-8 and compact fluorescent (CFL) lamps with an installed power of $7.2 \mathrm{~kW}$. Of this capacity, $72 \%$ provides supplemental lighting to day-lit zones; the remaining $28 \%$ provides primary lighting to the building's central core. Fluorescent luminaires with electronic ballasts consume roughly $75 \%$ less energy than incandescent luminaires with the same output. They also consume roughly $15 \%$ to $25 \%$ less energy than T-12 fluorescent luminaires with magnetic ballasts. Initially, designers wanted to use high-intensity discharge (HID) lamps for the high-bay areas with 24-ft (7.3-m) ceilings because of concerns about using fluorescent lamps far from the floor. However, because the lights were to be controlled by daylight sensors, they would need to be able to switch on and off quickly. Therefore, the design team chose fluorescents because of the difficulties in starting HID lamps. 

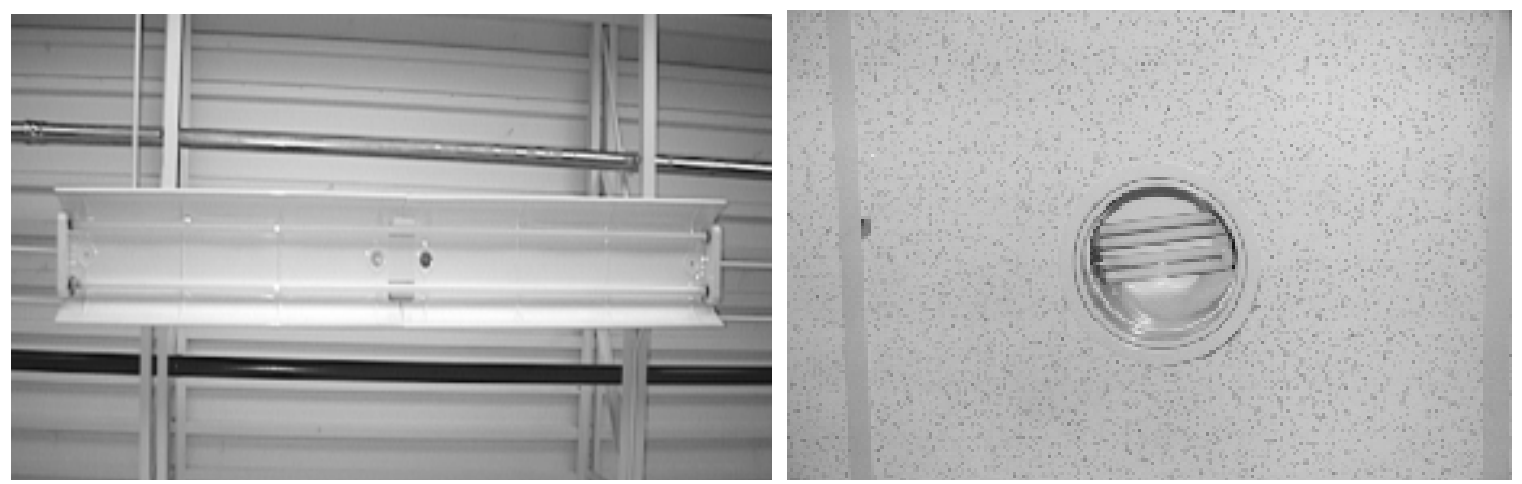

Figure 4-10 Efficient electric lighting luminaires include T-8 (left photo) and CFL can fixtures (right photo)

Table 4-2 Installed Electric Lighting Power

\begin{tabular}{|l|l|r|r|c|}
\hline \multicolumn{1}{|c|}{ Application } & \multicolumn{1}{c|}{ Type of fixture } & \multicolumn{1}{c|}{ W } & W/ft & \% of total \\
\hline Interior overhead & T-8 and CFL & 7,200 & 0.73 & $90 \%$ \\
\hline Exterior & CFL and LPS & 517 & 0.05 & $7 \%$ \\
\hline Emergency & $\begin{array}{l}\text { LED exit and egress } \\
\text { lighting }\end{array}$ & 225 & 0.02 & $3 \%$ \\
\hline \multicolumn{2}{|l}{ Total } & $\mathbf{7 , 9 4 2}$ & $\mathbf{0 . 8 0}$ & $\mathbf{1 0 0 \%}$ \\
\hline
\end{tabular}

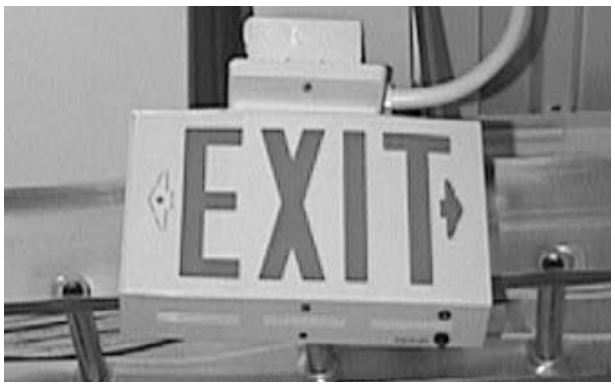

\section{Figure 4-11 LED emergency exit sign}

Exterior lighting is provided by low-pressure sodium wall packs over the east and west doors. A CFL can fixture placed over the front door provides additional illumination.

Inside, low-energy emergency exit signs were integrated into the electric lighting plan (Figure 4-11). These signs use solid-state light emitting diodes (LEDs) to consume only $1.8 \mathrm{~W}$ of electricity compared to their $40-\mathrm{W}$ incandescent and 26-W compact fluorescent counterparts. Egress lighting was provided by battery-powered wall-packs (Figure 4-12). Battery ballasted fluorescent fixtures were not used because of high parasitic loads. High-efficiency lighting options such as these reduced the total LPD from 1.5 to 0.8 $\mathrm{W} / \mathrm{ft}^{2}\left(16.1\right.$ to $\left.8.6 \mathrm{~W} / \mathrm{m}^{2}\right)$. The $47 \%$ reduction in LPD also contributes toward a major reduction in HVAC system load and overall building energy savings. 


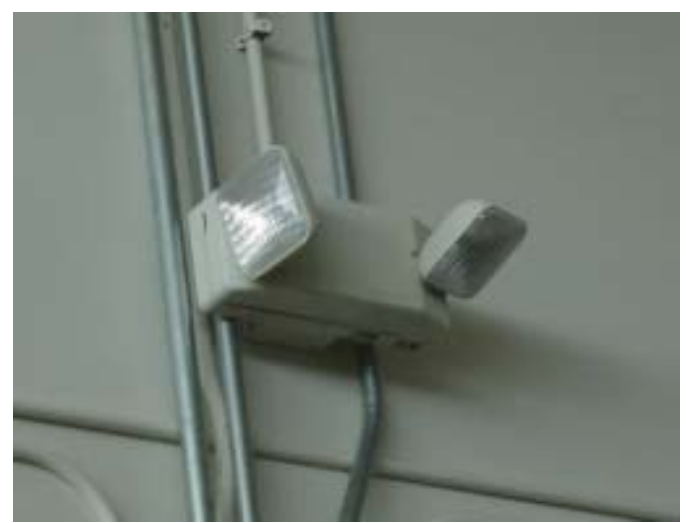

Figure 4-12 Egress lighting

\subsection{Mechanical Systems}

NREL's TTF design reduced solar gains, which had important implications for the heating and cooling design. It was essential to design the thermal envelope to reduce HVAC loads.

A VAV air-handling unit located in the mechanical mezzanine serves the main building. Figure 4-13 diagrams the air system that serves the main building. The main air handler supplies conditioned air to three zones. One zone is located in the low-bay (office) area, a second zone serves the west mid-bay and high-bay laboratory areas, and a third zone conditions the east mid-bay area and a small portion of the east end of the low-bay. Outside air enters the building on the south mid-clerestory. The outside air is introduced into the building only when the economizer of evaporative cooler is operating. Ductwork from this system is short with large diffusers. In addition, the ductwork in the building is larger than standard practice in order to reduce the pressure drop associated with moving air through the system. Most of the air is introduced in the low-bay area and flows through the west mid-bay and into the highbay. Additional diffusers in these zones can help control temperature. The return is in the east mid-bay. The long path for the conditioned air results in the building serving as its own plenum.

Heating is provided via parallel VAV boxes and hot water is supplied from NREL's central heating plant. The fans in these units operate only when heating is required - note that they had to be reprogrammed to operate in this manner. In this mode, the VAV portion of the box is closed. Note that the tie to the NREL central plan was a requirement for this campus building. An alternative would have been a natural gas fired forced-air condensing furnace. 


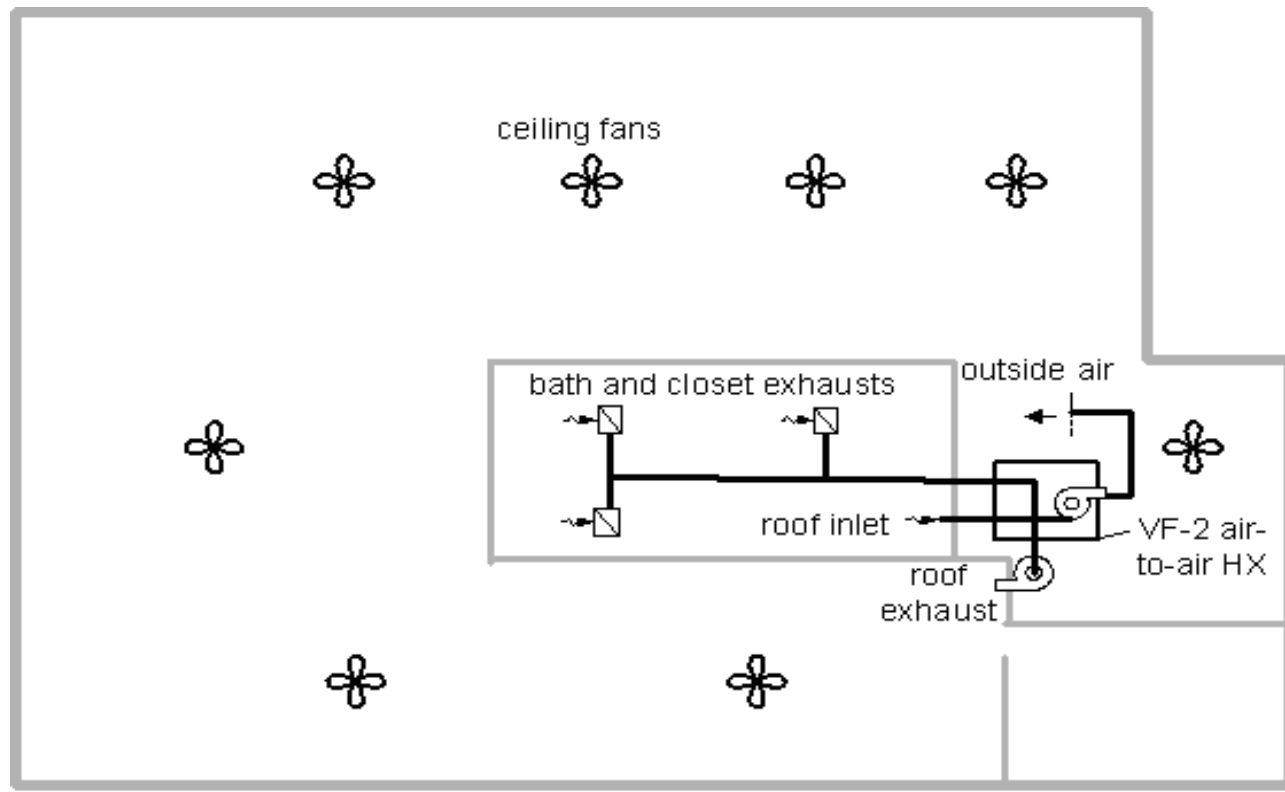

(a)

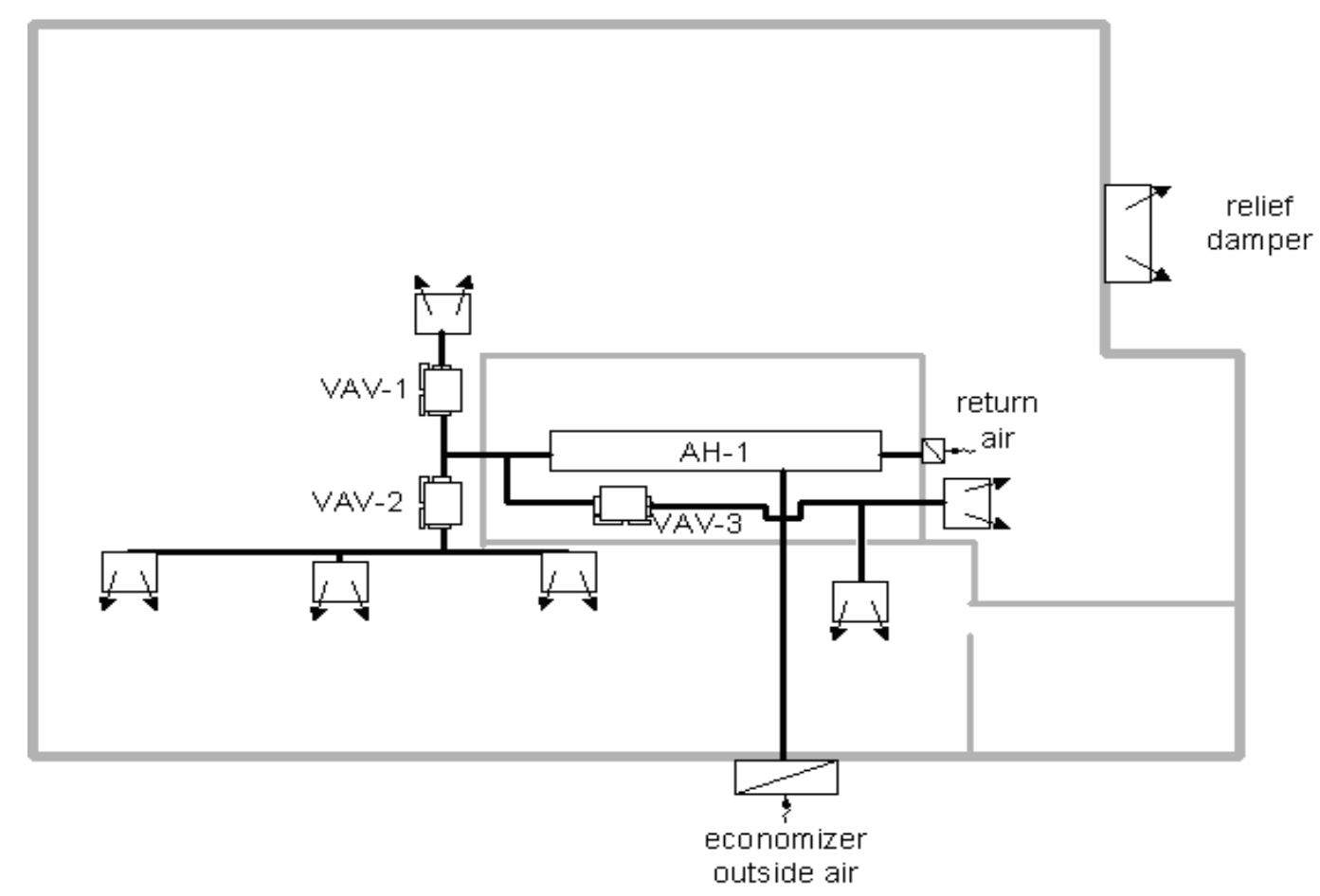

(b)

Figure 4-13 Schematics of main building air systems (a) ventilation air system, (b) heating and air-conditioning system

Figure 4-14 diagrams the main air handler. The system was designed to meet the building's normal cooling loads, while keeping humidity levels within the comfort range without the use of conventional cooling coils. The main supply fan is variable speed and rated for $10,500 \mathrm{cfm}(4,956 \mathrm{~L} / \mathrm{s})$. The evaporative cooler is a two-stage, direct and indirect evaporative cooler sized for an airflow rate of 
$10,000 \mathrm{cfm}(4720 \mathrm{~L} / \mathrm{s})$. The direct section of the evaporative cooling unit has a rated effectiveness of $90 \%$; the indirect portion has a rated effectiveness of $75 \%$ (S.A. 1993). Air for the secondary side of the indirect section is drawn from the building and then exhausted outside using a 5,300-cfm $(2,501-\mathrm{L} / \mathrm{s})$ variable-speed fan. The evaporative cooling system is equipped with two $0.16-\mathrm{hp}(0.12-\mathrm{kW})$ water pumps to wet the cooling medium. Separate pumps allow for independent control of the two evaporative stages. A 12-in. (30.5-cm) section of ductwork precedes the evaporative cooler if a chilled water coil were ever needed. This section was added by the engineer as a precaution as the evaporative system cannot meet the loads $100 \%$ of the time.

The main supply fan's speed is controlled by static pressure in the supply duct, which is affected by the damper positions in the VAV boxes. The controls determine the minimum static pressure required to meet the load so that at least one VAV box is completely open.

The main air handler is used only for cooling; it is turned off when cooling is not needed. There are four different operating modes for the air handler: (1) economizer, (2) direct evaporative cooling, (3) indirectdirect evaporative cooling, and (4) indirect evaporative cooling. When outside conditions are favorable, the air handler meets cooling loads by economizing where outside air and return air (drawn from the east mid-bay) are mixed to meet a control temperature.

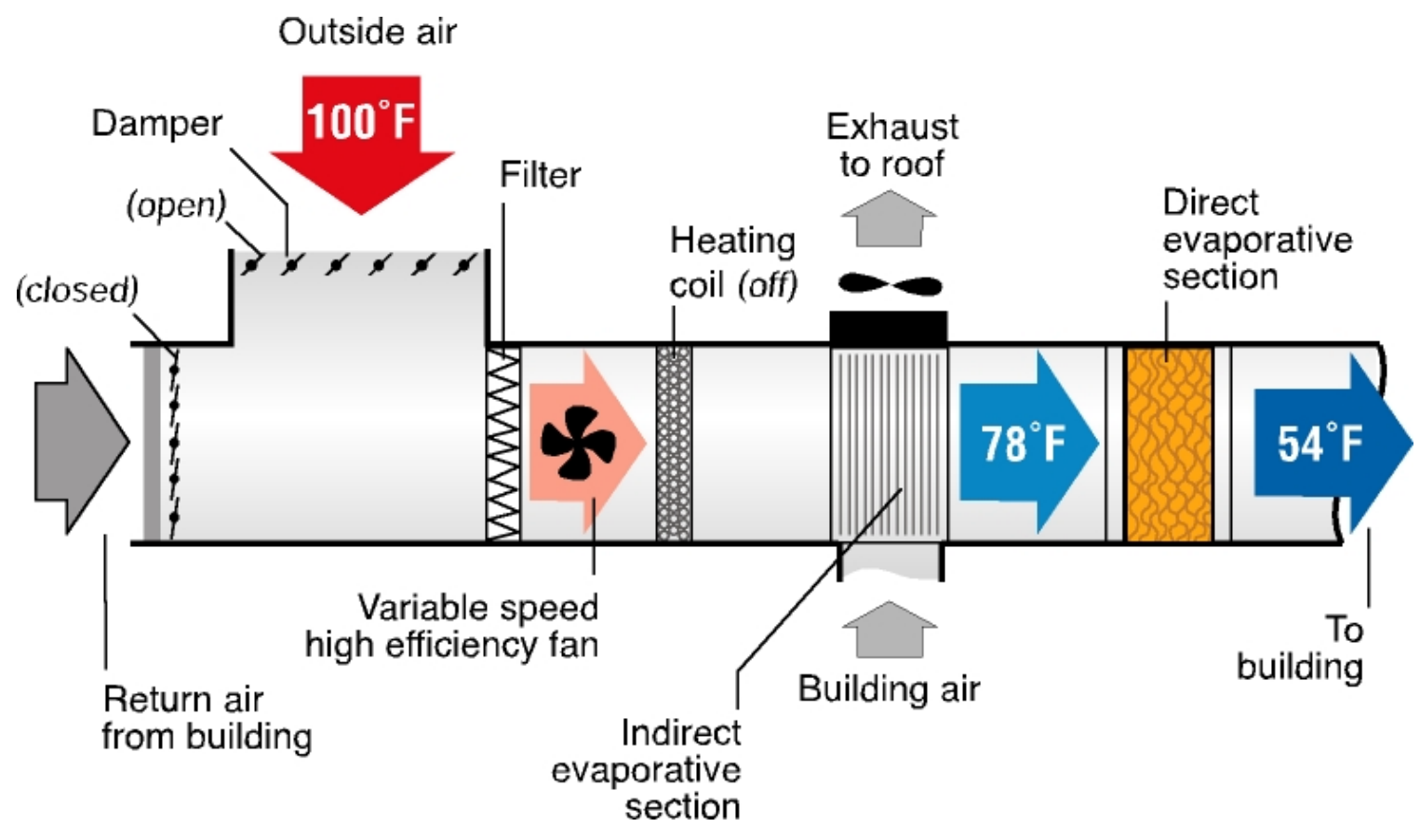

Figure 4-14 Main air handler with indirect/direct evaporative cooling

When outside conditions are not favorable for economizer operation, the air handler draws $100 \%$ outside air and uses the evaporative cooling system. If outside relative humidity is acceptable, the direct evaporative cooling section is used. If loads or outdoor temperatures become more demanding than what can be met with the direct section alone, the indirect section is turned on (by starting the scavenger fan). If outdoor humidity is too high, only the indirect section is used. Building air is not recirculated in the evaporative cooling mode. The surplus of air is discharged from the building with a passive relief damper located on the east wall in the high-bay. 
Figure 4-15 shows the operation of the evaporative cooler on a psychrometric chart. The $2.5 \%$ Denver cooling design day temperatures are $93^{\circ} \mathrm{F}$ dry-bulb $/ 59^{\circ} \mathrm{F}$ wet-bulb $\left(34^{\circ} \mathrm{C}\right.$ dry-bulb $/ 15^{\circ} \mathrm{C}$ wet-bulb). Under these conditions, the indirect section of the evaporative cooler is able to supply air at $67^{\circ} \mathrm{F}$ dry-bulb $/ 50^{\circ} \mathrm{F}$ wet-bulb $\left(20^{\circ} \mathrm{C}\right.$ dry-bulb $/ 10^{\circ} \mathrm{C}$ wet-bulb). Operating the direct section of the evaporative cooler reduces the supply air temperature further to $55^{\circ} \mathrm{F}$ dry-bulb $/ 50^{\circ} \mathrm{F}$ wet-bulb $\left(13^{\circ} \mathrm{C}\right.$ dry-bulb $/ 10^{\circ} \mathrm{C}$ wet-bulb).

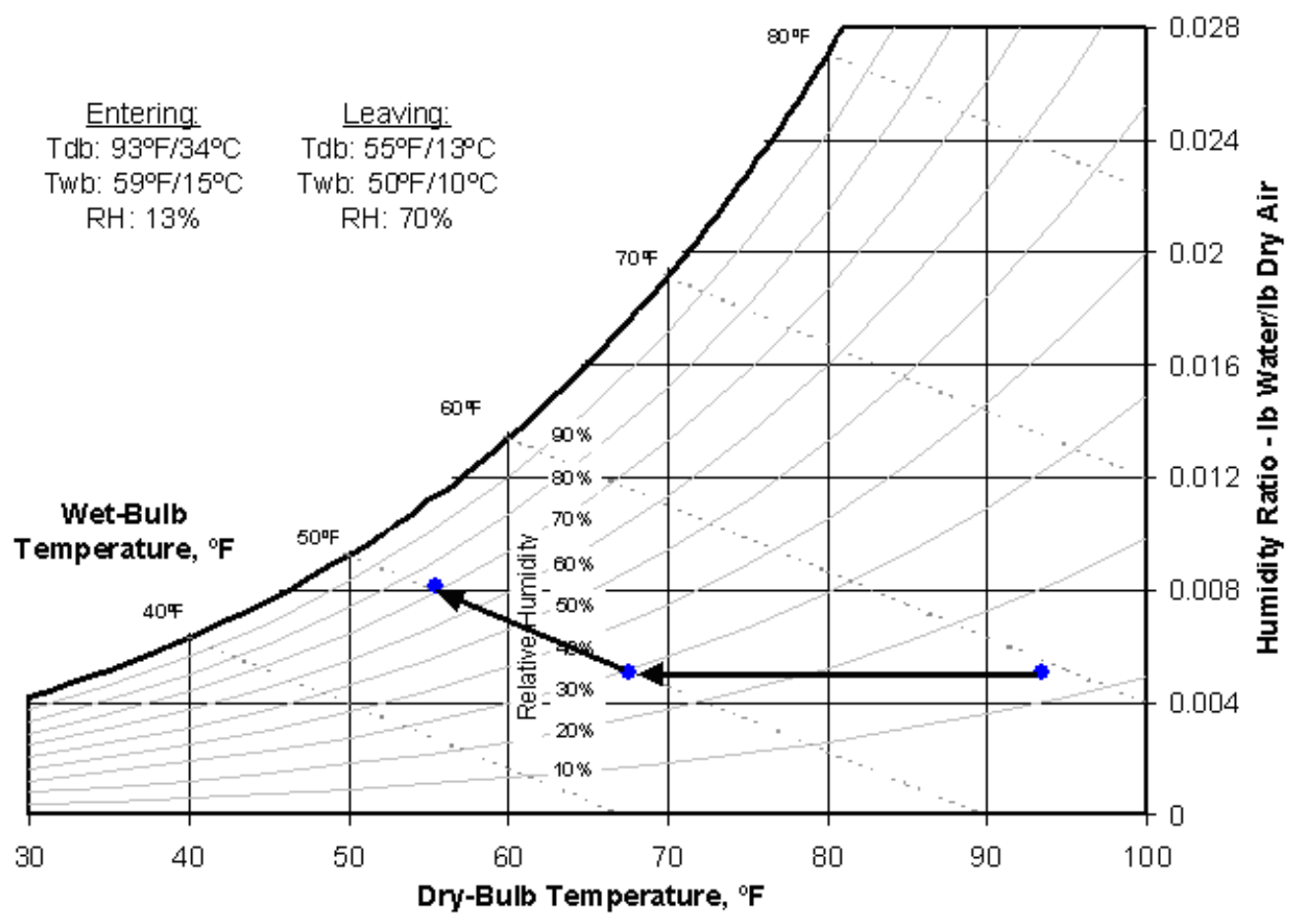

Figure 4-15 Evaporative cooler operation on a cooling design day

Figure 4-16 shows a picture of one of the three fan-powered VAV terminals. Hot-water coils located inside the VAV boxes provide all heating. Hot water is supplied to the coils from NREL's central heating plant. The auxiliary fans housed within these parallel mixing boxes pull local air through water heating coils and expel the conditioned air back into the zones, much like a stand-alone fan coil unit. A heating coil was installed in the main air handler as a backup. Hot water is occasionally run through the main heating coil for purposes of freeze protection, but the main air handler is run only when cooling is needed. Because the heating coil is always present, but never used, the main supply fan experiences unnecessary pressure drop. 


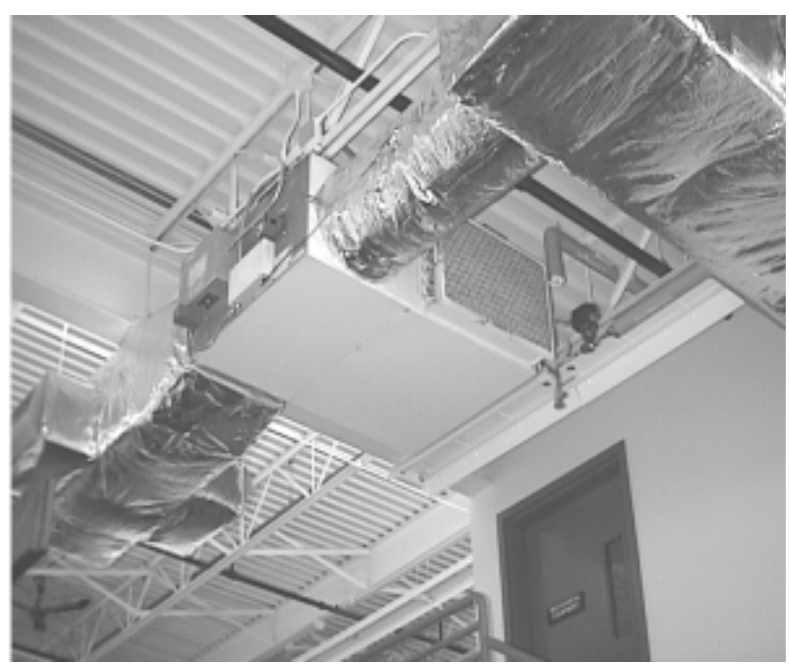

Figure 4-16 Parallel terminal boxes allow for heating without operating main air-handler

Outdoor air for ventilation is provided by a dedicated system that can supply $615 \mathrm{cfm}(290 \mathrm{~L} / \mathrm{s})$ of fresh outdoor air through a separate heat-recovery ventilator. Figure 4-17 shows the ventilator, which uses an HEX to preheat (winter) or pre-cool (summer) incoming air, using recovered energy from the building exhaust. The heat-recovery ventilator was specified with an effectiveness of 70\% (FERC 1995). The building exhaust draws air from the core (restrooms, kitchen, janitorial closet) at a rate of $450 \mathrm{cfm}(212$ $\mathrm{L} / \mathrm{s}$ ) before entering the ventilator. The exhaust fan is controlled by a schedule operating during occupied hours plus two hours before occupancy in the morning. The heat-recovery unit contains its own supply fan, which is controlled to operate only when the exhaust fan is running and when no outside air is introduced with the main air handler. There is no need to run the HEX when outside air is introduced into the building during economization and evaporative cooling. Air is introduced into the east mid-bay. This design allows the air to circulate around the entire building as it moves from the inlet point to the exhaust. Note the flow pattern is the reverse of the flow pattern induced by the main air handler. The path from the inlet point to the exhausts is as long as possible such that air is still mixed even if the supply fan is not operating. The ceiling fans also mix air in the space.

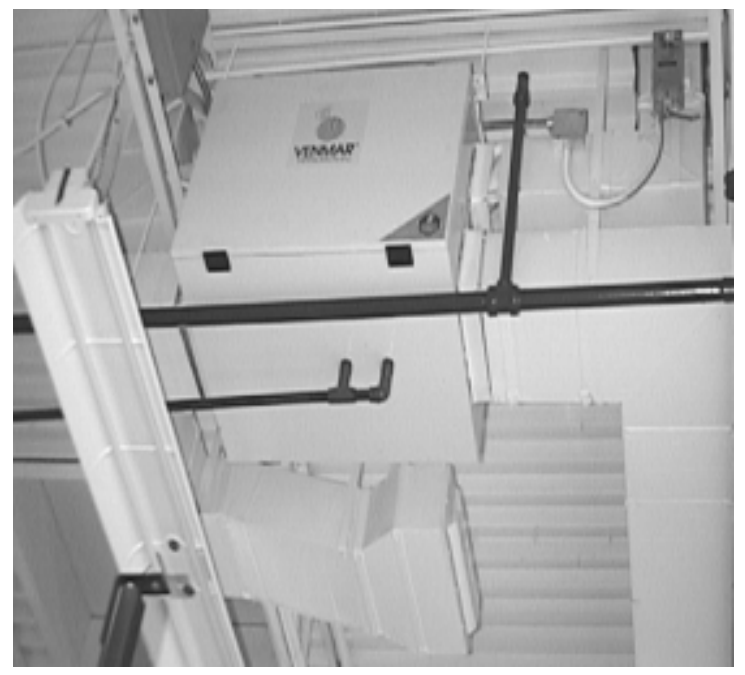

Figure 4-17 Air-to-air heat exchanger removes air from restrooms and kitchen and provides fresh air to building 
Figure 4-18 shows one of the ceiling fans used to enhance mixing of room air. The fans eliminate the need for the extensive ductwork conventionally used to distribute conditioned and ventilation air. The fans provide for good mixing of ventilation air and reduced temperature stratification that could become a problem with high ceilings, and aid cooling in the summer by moving air.

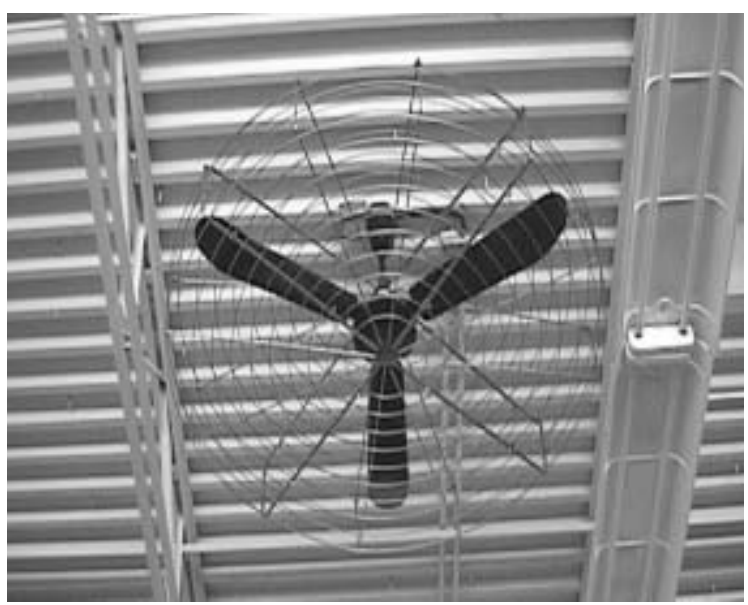

Figure 4-18 Ceiling fans destratify the air without using the main air-handler

\subsection{Conference Room Conditioning}

A packaged single-zone rooftop unit located inside the east mid-bay serves the conference room. An underlying design philosophy for the TTF HVAC systems was to minimize the amount of work that fans have to do to move air. The philosophy led to minimizing the amount of ductwork compared to conventional practice and separating systems used for cooling, heating, and ventilation so that systems could run independently and with less pressure drop.

Figure 4-19 diagrams the air system chosen to condition the conference room. A separate, single-zone, packaged rooftop-style unit was mounted in the east mid-bay (Figure 4-20) to take advantage of lower air temperatures (compared to outdoor air temperatures) on the condenser side. Condenser heat is eventually rejected from the building by the economizer or flushed out of the building with the evaporative cooler. The result is that the system is using indirect cooling based on cooling provided by the central system.

Heat to the conference room is provided with a hot-water coil using district hot water. Cooling is provided with a DX coil to cool the space. The drop ceiling in the conference room forms a return air plenum. When the package cycles on, it also runs an HEX that preconditions outside air. The original design intent for the conference room equipment was to use a much smaller, split-system. The design also suffers from not being able to operate in economizer mode because all outside air must enter through the HEX.

Scavenger air for the secondary side of the HEX is drawn from the return air plenum and is dumped to the east mid-bay zone. This is also a problem area in that the heat exchanged in the HEX is not leaving the building. Drawing an energy balance around the building shows that this is not an effective use of the HEX. 
Package

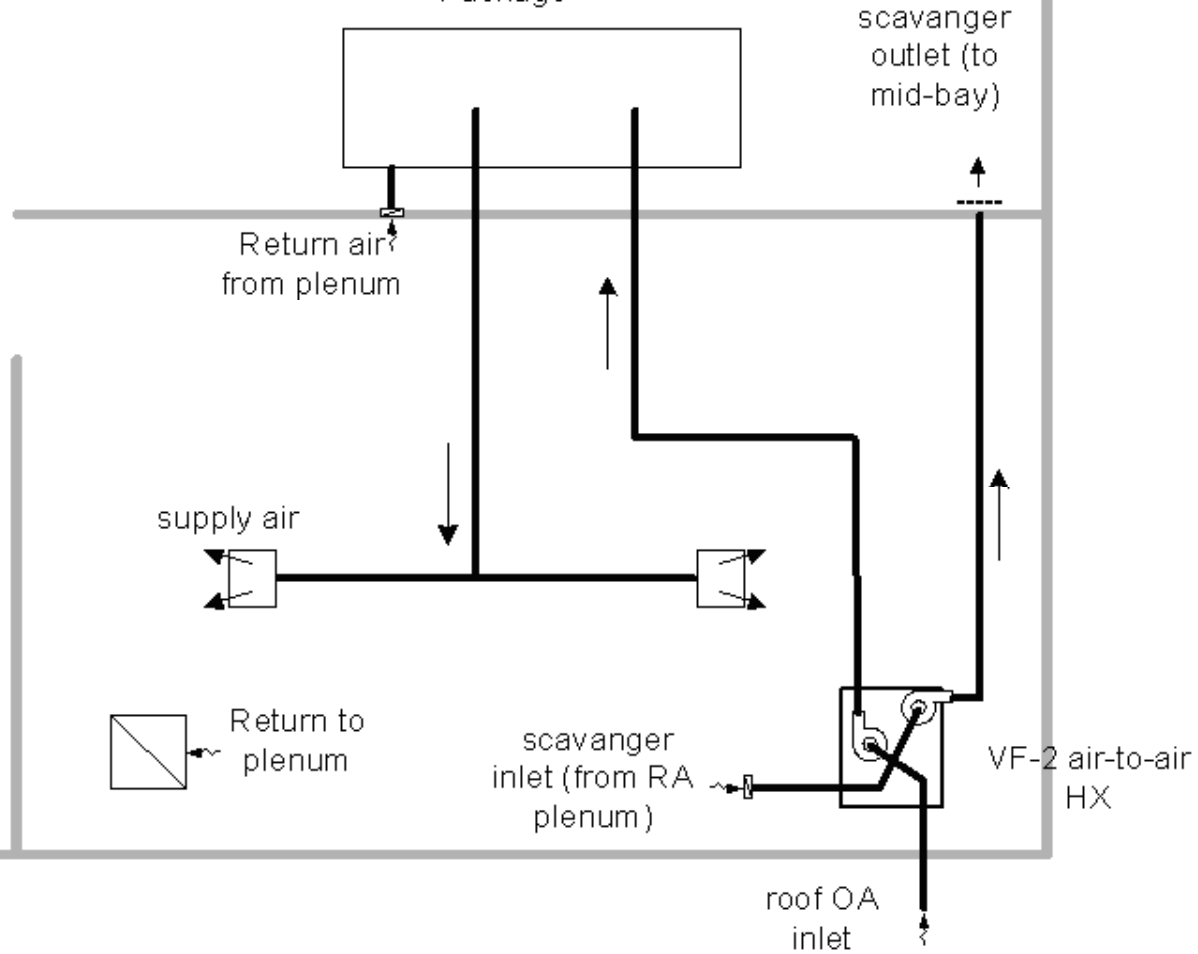

Figure 4-19 Conference room HVAC schematic

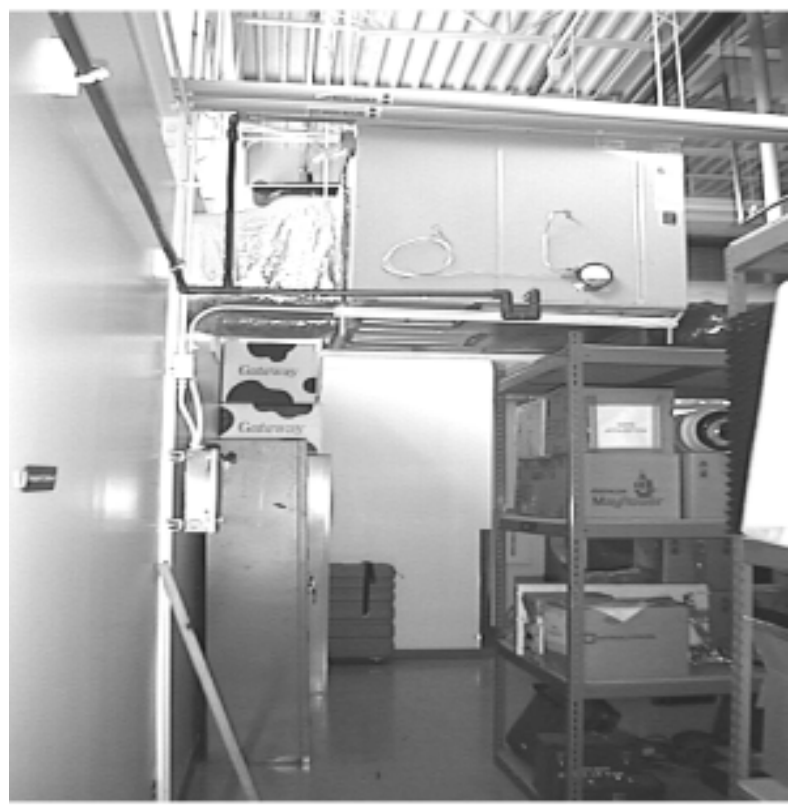

Figure 4-20 Conference room rooftop packaged system (located indoors) 


\subsection{Energy Management System}

The TTF uses a digital building control system to control HVAC and lighting. Figure 4-21 shows the EMS panel and interface PC. The EMS allows building systems to be monitored, tuned, and diagnosed in order to keep the building operating as designed. The EMS also is responsible for collecting diagnostic and performance data. Two EMS panels in the building are used for control and data acquisition. The primary panel also communicates to three subpanels that control the VAV boxes. The two EMS panels are connected to the NREL site EMS backbone. A computer provides a user interface to the system. The system is standard for buildings on the NREL site, but probably much more complicated than one that might be installed in a conventional commercial building this size.
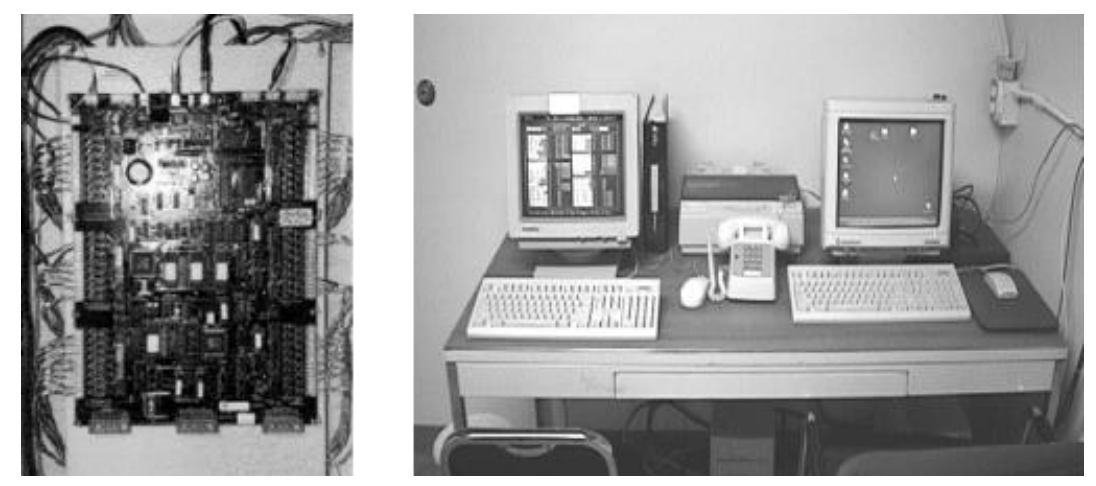

Figure 4-21 EMS input/output panel (left) with PC interface (right)

The EMS was configured with the input points listed in Table 4-3. The rated accuracies for each type of input point are listed in Table 4-4. These tables indicate the type of input point and the expected accuracy of the point based on the manufacturer's literature for the sensor. In addition, the table indicates whether the point is used for control. Some points were planned for the system and were not used directly for control. In some cases, the points were used for the monitoring and evaluation. Other points were planned and installed, but never used for controls or monitoring.

A series of output points directly controlled equipment in the building. These are listed in Table 4-5. Sensors provide a voltage ( 0 to 5 Volts), current ( 4 to $20 \mathrm{~mA}$ ) output signal, or a switch closure signal. The EMS uses 0-10 VDC (direct-current voltage) output signals to control all devices. Discrete devices require an isolation relay to provide the on/off signal.

The control's contractor commissioned all sensors independent of the building commissioning and verified that output signals were connected to appropriate equipment and that all valves, dampers, and motors were operating properly. Control algorithms were programmed by the control's contractor with sequencing developed by the engineer with set points as shown in Table 4-6. 
Table 4-3 Input points for EMS

\begin{tabular}{|c|c|c|c|}
\hline $\begin{array}{l}\text { Sensor Type } \\
\text { Location }\end{array}$ & $\begin{array}{l}\text { EMS Control Point } \\
\text { Name }\end{array}$ & $\begin{array}{l}\text { EMS Input } \\
\text { Location }\end{array}$ & $\begin{array}{l}\text { Used for } \\
\text { Control? }\end{array}$ \\
\hline \multicolumn{4}{|l|}{ Temperatures (RTD) } \\
\hline Outdoor air (shadowed) & $\begin{array}{c}\text { TTF_OAT } \\
\text { TTF_OAT_XFER }{ }^{1}\end{array}$ & $\begin{array}{c}\text { 40.IP1 } \\
\text { 40.GV7, } \\
\text { 41.GV51 }\end{array}$ & $\begin{array}{l}\text { No } \\
\text { Yes }\end{array}$ \\
\hline VAV discharge air & TTF_AHU1_DA_TEMP & 40.IP2 & Yes \\
\hline VAV return air intake & TTF_AHU1_RA_TEMP ${ }^{2}$ & 40.GV20 & Yes \\
\hline Conference room & TTF_AHU2_ZN_TEMP & $40 . I P 5$ & Yes \\
\hline $\begin{array}{l}\text { Hot-water supply (site } \\
\text { spine) }\end{array}$ & TTF_HWS_TEMP & $40 . I P 6$ & Yes \\
\hline Hot-water return (spine) & TTF_HWR_TEMP & $40 . I P 7$ & Yes \\
\hline $\begin{array}{l}\text { West low-bay (low } 4 \mathrm{ft} \\
{[1.2 \mathrm{~m}] \text { off floor) }}\end{array}$ & TTF_L_BAY_W_TMP2 & 41.IP2 & Yes \\
\hline West low-bay (high) & TTF_L_BAY_W_TMP1 & 41.IP1 & Yes \\
\hline West mid-bay (low) & TTF_M_BAY_W_TMP2 & 41.IP6 & Yes \\
\hline West mid-bay (high) & TTF_M_BAY_W_TMP1 & 41.IP5 & Yes \\
\hline West high-bay (low) & TTF_H_BAY_W_TMP2 & $41 . I P 10$ & No \\
\hline West high-bay (high) & TTF_H_BAY_W_TMP1 & 41.IP9 & No \\
\hline East low-bay (low) & TTF_L_BAY_E_TMP2 & 41.IP4 & Yes \\
\hline East low-bay (high) & TTF_L_BAY_E_TMP1 & 41.IP3 & Yes \\
\hline East mid-bay (low) & TTF_M_BAY_E_TMP2 & 41.IP8 & Yes \\
\hline East mid-bay (high) & TTF_M_BAY_E_TMP1 & $41 . I P 7$ & Yes \\
\hline East high-bay (low) & TTF_H_BAY_E_TMP2 & 41.IP12 & Yes \\
\hline East high-bay (high) & TTF_H_BAY_E_TMP1 & 41.IP11 & Yes \\
\hline \multicolumn{4}{|l|}{ Relative Humidity } \\
\hline $\begin{array}{l}\text { Outdoor (east end of } \\
\text { building) }\end{array}$ & $\begin{array}{c}\text { TTF_RH_0_1VOLT } \\
\text { REL_HUM }\end{array}$ & $\begin{array}{l}41 . I P 23 \\
41 . G V 12\end{array}$ & $\begin{array}{l}\text { No } \\
\text { Yes }\end{array}$ \\
\hline \multicolumn{4}{|l|}{$\begin{array}{l}\text { Pressure Difference with } \\
\text { respect to Building }\end{array}$} \\
\hline $\begin{array}{l}\text { After direct pad in supply } \\
\text { duct }\end{array}$ & $\begin{array}{l}\text { TTF_AHU1_DCT_PRS } \\
\text { TTF_AHU1_PRS_GV }\end{array}$ & $\begin{array}{c}\text { 40.IP3 } \\
40 . \mathrm{GV} 32\end{array}$ & $\begin{array}{l}\text { No } \\
\text { No }\end{array}$ \\
\hline \multicolumn{4}{|l|}{$\begin{array}{l}\text { Pressure Difference with } \\
\text { respect to Building }\end{array}$} \\
\hline $\begin{array}{l}\text { Outdoor (east end of } \\
\text { building) }\end{array}$ & TTF_BLDG_PRES & $40 . \mathrm{IP4}$ & No \\
\hline \multicolumn{4}{|l|}{ Turbine Flow Meter } \\
\hline $\begin{array}{l}\text { Hot-water supply from site } \\
\text { spline }\end{array}$ & TTF_FLOW_METER & 40.PP1 & No \\
\hline Airflow Rate & & & \\
\hline
\end{tabular}

${ }^{1}$ The outdoor temperature is actually recorded from the building next door as the TTF sensor is located in the OA ductwork and does not provide accurate temperatures during the day.

${ }^{2}$ Equal to TTF_M_BAY_E_TMP1. 
Table 4-3 Input points for EMS

\begin{tabular}{|c|c|c|c|}
\hline $\begin{array}{c}\text { Sensor Type } \\
\text { Location }\end{array}$ & $\begin{array}{c}\text { EMS Control Point } \\
\text { Name }\end{array}$ & $\begin{array}{l}\text { EMS Input } \\
\text { Location }\end{array}$ & $\begin{array}{l}\text { Used for } \\
\text { Control? }\end{array}$ \\
\hline VAV Box \#1 & TTF_VAV1_IC & STAT.IP1 & Yes \\
\hline VAV Box \#2 & TTF_VAV2_IC & STAT.IP2 & Yes \\
\hline VAV Box \#3 & TTF_VAV3_IC & STAT.IP3 & Yes \\
\hline \multicolumn{4}{|l|}{ Occupancy Sensors } \\
\hline West low-bay & TTF_OC_ST_WLB_IP & 41.IP28 & Yes \\
\hline West mid-bay & TTF_OC_ST_WMB_IP & 41.IP27 & Yes \\
\hline West high-bay & TTF_OC_ST_WHB_IP & 41.IP26 & Yes \\
\hline East low-bay & TTF_OC_ST_ELB_IP & 41.IP31 & Yes \\
\hline East mid-bay & TTF_OC_ST_EMB_IP & $41 . I P 30$ & Yes \\
\hline East high-bay & TTF_OC_ST_EHB_IP & 41.IP29 & Yes \\
\hline Conference room & TTF_AHU2_MOTION & $40 . I P 10$ & No \\
\hline \multicolumn{4}{|l|}{ Illumination Sensor } \\
\hline $\begin{array}{l}\text { West high-bay (6 ft [1.8 m] } \\
\text { from clerestory window) }\end{array}$ & $\begin{array}{c}\text { TTF_FC } \\
\text { TTF_FC_CALC }\end{array}$ & $\begin{array}{l}\text { 41.IP21 } \\
41 . G V 50\end{array}$ & $\begin{array}{l}\text { Yes } \\
\text { Yes }\end{array}$ \\
\hline \multicolumn{4}{|l|}{ Status Feedback Switches } \\
\hline VAV supply fan & TTF_AHU1_SF_AMPS & 40.IP21 & No \\
\hline Indirect evaporative pump & TTF_AHU1_IP_AMPS & 40.IP22 & Yes \\
\hline Direct evaporative pump & TTF_AHU1_DP_AMPS & 40.IP23 & Yes \\
\hline Evaporative scavenger fan & TTF_SCVGRFN_AMPS & 40.IP20 & No \\
\hline Ventilation fan & TTF_VF2_AMPS & 40.IP17 & No \\
\hline Conference HVAC & TTF_AHU2_AMPS & 40.IP13 & No \\
\hline $\begin{array}{l}\text { Conference ventilation } \\
\text { exhaust fan }\end{array}$ & TTF_VF1_EF_AMPS & 40.IP18 & No \\
\hline $\begin{array}{l}\text { Conference ventilation } \\
\text { supply fan }\end{array}$ & TTF_VF1_SF_AMPS & 40.IP19 & No \\
\hline Hot-water pump \#1 & TTF_HWP1_AMPS & 40.IP14 & No \\
\hline Hot-water pump \#2 & TTF_HWP2_AMPS & 40.IP15 & No \\
\hline Building exhaust fan & TTF_EF1_AMPS & 40.IP16 & No \\
\hline \multicolumn{4}{|l|}{ Ceiling Fans } \\
\hline West low-bay & TTF_CF7_AMPS & 41.IP19 & No \\
\hline West mid-bay & TTF_CF1_AMPS & 41.IP13 & No \\
\hline West high-bay (2) & $\begin{array}{l}\text { TTF_CF3_AMPS } \\
\text { TTF_CF4_AMPS }\end{array}$ & $\begin{array}{l}\text { 41.IP15 } \\
\text { 41.IP16 }\end{array}$ & $\begin{array}{l}\text { No } \\
\text { No }\end{array}$ \\
\hline East low-bay & TTF_CF8_AMPS & 41.IP20 & No \\
\hline East mid-bay & TTF_CF2_AMPS & 41.IP14 & No \\
\hline East high-bay (2) & $\begin{array}{l}\text { TTF_CF5_AMPS } \\
\text { TTF_CF6_AMPS }\end{array}$ & $\begin{array}{l}41 . I P 17 \\
41 . I P 18 \\
\end{array}$ & $\begin{array}{l}\text { No } \\
\text { No }\end{array}$ \\
\hline \multicolumn{4}{|l|}{ Other Monitored Points } \\
\hline Conference room door & TTF_AHU2_DOOR_IP & 41.IP25 & No \\
\hline Hot-water supply temp & TTF_HWS_TEMP & $40 . I P 6$ & No \\
\hline Hot-water return temp & TTF_HWR_TEMP & 40.IP7 & No \\
\hline
\end{tabular}


Table 4-3 Input points for EMS

\begin{tabular}{|l|c|c|c|}
\hline $\begin{array}{c}\text { Sensor Type } \\
\text { Location }\end{array}$ & $\begin{array}{c}\text { EMS Control Point } \\
\text { Name }\end{array}$ & $\begin{array}{c}\text { EMS Input } \\
\text { Location }\end{array}$ & $\begin{array}{c}\text { Used for } \\
\text { Control? }\end{array}$ \\
\hline Cooling make-up water & TTF_EVP_H20_FILL & $40 . I P 9$ & No \\
\hline Building freeze sensor & TTF_AHU1_FREEZ & $40 . I P 24$ & Yes \\
\hline Conf room freeze sensor & TTF_AHU2_FREEZ & $40 . I P 12$ & No \\
\hline $\mathrm{CO}_{2}$ sensor & TTF_CO2_IP & $41 . \mathrm{IP} 22$ & No \\
\hline Unknown & TTF_IP_WH & $41 . \mathrm{IP} 32$ & No \\
\hline
\end{tabular}

Table 4-4 Sensor Types and Associated Accuracy (from specification sheets)

\begin{tabular}{|l|c|c|}
\hline \multicolumn{1}{|c|}{ Data Type } & Type of Sensor & Accuracy \\
\hline \hline Temperature ( $\left.{ }^{\circ} \mathrm{F}\right)$ & Thermister & $\pm 0.36 \%$ \\
\hline Relative Humidity (\%) & Capacitor & $\pm 3 \%$ \\
\hline Amperage (Amp) & Current transformer & $\pm 2 \%$ \\
\hline Energy (Wh) & Watt-hour transducer & $\pm 0.5 \%$ \\
\hline Pressure (miwc) & Pressure transducer & $\pm 1 \%$ \\
\hline Luminance levels (fc) & Blue enhanced photo diode & $\pm 1 \%$ \\
\hline
\end{tabular}

Table 4-5 Energy Management System Output Points

\begin{tabular}{|l|c|c|c|}
\hline \multicolumn{1}{|c|}{ Location } & EMS Control Point Name & $\begin{array}{c}\text { EMS Input } \\
\text { Location }\end{array}$ & $\begin{array}{c}\text { Output } \\
\text { Type }\end{array}$ \\
\hline AHU Equipment & & & \\
\hline Building relief damper & TTF_BLDG_RELIEF & 40. OP1 & Analog \\
\hline VAV supply fan & TTF_AHU1_SFSS & 40. OP40 & Digital \\
\hline VAV supply fan speed & TTF_AHU1_SFSPEED & 40. OP2 & Analog \\
\hline Building exhaust fan & TTF_EF1_SS & 40. OP14 & Analog \\
\hline Ventilation fan & TTF_VF1_SS & 40. OP36 & Digital \\
& TTF_VF2_SS & 40. OP37 & Digital \\
\hline Ventilation fan speed & TTF_VF1_SPEED & 40. OP9 & Analog \\
\hline Economizer dampers & TTF_VF2_SPEED & 40. OP10 & Analog \\
\hline Indirect evaporative pump & TTF_AHU1_ECNOMZR & 40. OP3 & Analog \\
\hline Direct evaporative pump & TTF_AHU1_IPMP_SS & 40. OP38 & Digital \\
\hline VAV AHU-1 hot-water valve & TTF_AHU1_DPMP_SS & 40. OP39 & Digital \\
\hline Building hot-water mixing valve & TTF_AHU1_HWVLV & 40. OP4 & Analog \\
\hline Hot-water pump \#1 & TTF_HWR_VLV & 40. OP5 & Analog \\
\hline Hot-water pump \#2 & TTF_HWP1_SS & 40. OP16 & Analog \\
\hline Evaporative tank fill & TTF_HWP2_SS & 40. OP17 & Analog \\
\hline Evaporative tank drain & TTF_EVAP_FILL & 40. OP6 & Digital \\
\hline Evaporative scavenger fan & TTF_EVAP_DRAIN & 40. OP15 & Digital \\
\hline
\end{tabular}


Table 4-5 Energy Management System Output Points

\begin{tabular}{|c|c|c|c|}
\hline Location & EMS Control Point Name & $\begin{array}{l}\text { EMS Input } \\
\text { Location }\end{array}$ & $\begin{array}{c}\text { Output } \\
\text { Type }\end{array}$ \\
\hline Conference Room AHU (AHU-2) & TTF_AHU2_SS & 40.OP34 & Digital \\
\hline Conference HEX fan & TTF_VF1_EFSS & 40.OP13 & Digital \\
\hline Conference compressor/AC & TTF_AHU2_COOL & $40.0 P 35$ & Digital \\
\hline Conference room hot-water valve & TTF_AHU2_HWVLV & $40.0 P 8$ & Analog \\
\hline \multicolumn{4}{|l|}{ Lighting } \\
\hline West low-bay & TTF_LT_SS_WLB_OP & $41 . \mathrm{OP} 41$ & Digital \\
\hline West mid-bay & TTF_LT_SS_WMB_OP & $41 . \mathrm{OP} 40$ & Digital \\
\hline West high-bay & TTF_LT_SS_WHB_OP & $41.0 P 39$ & Digital \\
\hline East low-bay & TTF_LT_SS_ELB_OP & $41 . \mathrm{OP} 44$ & Digital \\
\hline East mid-bay & TTF_LT_SS_EMB_OP & 41.OP43 & Digital \\
\hline East high-bay & TTF_LT_SS_EHB_OP & $41 . \mathrm{OP} 42$ & Digital \\
\hline \multicolumn{4}{|l|}{ Ceiling Fans } \\
\hline West low-bay & TTF_CF7_SS_WLB & $41 . \mathrm{OP} 15$ & Digital \\
\hline West low-bay speed & TTF_CF7_SPEED & $41 . \mathrm{OP} 7$ & Analog \\
\hline West mid-bay & TTF_CF1_SS_WMB & 41.OP9 & Digital \\
\hline West mid-bay reverse & TTF_CF1_REV_SS & 41.OP33 & Digital \\
\hline West mid-bay speed & TTF_CF1_SPEED & 41.OP1 & Analog \\
\hline West high-bay (2) & $\begin{array}{l}\text { TTF_CF3_SS_WHB } \\
\text { TTF_CF4_SS_CHB }\end{array}$ & $\begin{array}{l}41 . \mathrm{OP} 11 \\
41 . \mathrm{OP} 12\end{array}$ & $\begin{array}{l}\text { Digital } \\
\text { Digital }\end{array}$ \\
\hline West high-bay reverse (2) & $\begin{array}{l}\text { TTF_CF3_REV_SS } \\
\text { TTF_CF4_REV_SS }\end{array}$ & $\begin{array}{l}41 . \text { OP35 } \\
41 . \text { OP36 } \\
\end{array}$ & $\begin{array}{l}\text { Digital } \\
\text { Digital }\end{array}$ \\
\hline West high-bay speed (2) & $\begin{array}{l}\text { TTF_CF3_SPEED } \\
\text { TTF_CF4_SPEED }\end{array}$ & $\begin{array}{l}41 . \mathrm{OP} 3 \\
41 . \mathrm{OP} 4 \\
\end{array}$ & $\begin{array}{l}\text { Analog } \\
\text { Analog }\end{array}$ \\
\hline East low-bay & TTF_CF8_SS_ELB & 41.OP16 & Digital \\
\hline East low-bay speed & TTF_CF8_SPEED & $41 . \mathrm{OP} 8$ & Analog \\
\hline East mid-bay & TTF_CF2_SS_EMB & 41.OP10 & Digital \\
\hline East mid-bay reverse & TTF_CF2_REV_SS & $41 . \mathrm{OP} 34$ & Digital \\
\hline East mid-bay speed & TTF_CF2_SPEED & $41 . \mathrm{OP} 2$ & Analog \\
\hline East high-bay (2) & $\begin{array}{l}\text { TTF_CF5_SS_DEMO } \\
\text { TTF_CF6_SS_EHB }\end{array}$ & $\begin{array}{l}41 . \mathrm{OP} 13 \\
41 . \mathrm{OP} 14\end{array}$ & $\begin{array}{l}\text { Digital } \\
\text { Digital }\end{array}$ \\
\hline East high-bay reverse (2) & $\begin{array}{l}\text { TTF_CF5_REV_DEMO } \\
\text { TTF_CF6 REV SS }\end{array}$ & $\begin{array}{l}41 . \mathrm{OP} 37 \\
41 . \mathrm{OP} 38\end{array}$ & $\begin{array}{l}\text { Digital } \\
\text { Digital }\end{array}$ \\
\hline East high-bay speed (2) & $\begin{array}{c}\text { TTF_CF5_SPEED_DEMO } \\
\text { TTF_CF6_SPEED }\end{array}$ & $\begin{array}{l}41 . \mathrm{OP5} \\
41 . \mathrm{OP} 6\end{array}$ & $\begin{array}{l}\text { Analog } \\
\text { Analog }\end{array}$ \\
\hline
\end{tabular}


Table 4-6 Set-Point Values

\begin{tabular}{|l|c|}
\hline \multicolumn{1}{|c|}{ Description } & Typical Set Point \\
\hline VAV discharge air temperature & $54^{\circ} \mathrm{F} / 12^{\circ} \mathrm{C}$ \\
\hline High-bay and east mid-bay zone & $68^{\circ} \mathrm{F} / 20^{\circ} \mathrm{C}$ (Winter) \\
air temperature & $73^{\circ} \mathrm{F} / 23^{\circ} \mathrm{C}$ (Summer) \\
\hline Mid-bay and west low-bay zone & $68^{\circ} \mathrm{F} / 20^{\circ} \mathrm{C}$ (Winter) \\
air temperature & $63^{\circ} \mathrm{F} / 23^{\circ} \mathrm{C}$ (Summer) \\
\hline West low-bay luminance ${ }^{3}$ & $50 \mathrm{fc}$ \\
\hline West mid-bay luminance & $30 \mathrm{fc}$ \\
\hline West high-bay luminance & $65 \mathrm{fc}$ \\
\hline East low-bay luminance & $70 \mathrm{fc}$ \\
\hline East mid-bay luminance & $40 \mathrm{fc}$ \\
\hline East high-bay luminance & $72^{\circ} \mathrm{F} / 22^{\circ} \mathrm{C}$ \\
\hline Conference zone temperature & 30 minutes (Night) \\
\hline West low-bay luminaire timer & 20 minutes (Day) \\
\hline West mid-bay luminaire timer & 15 minutes (Night) \\
\hline West high-bay luminaire timer & 20 minutes (Day) \\
\hline East low-bay luminaire timer & 10 minutes (Day) \\
\hline East mid-bay luminaire timer & 20 minutes (Night) \\
\hline East high-bay luminaire timer & 70 minutes (Night) \\
\hline 50 minutes (Day)
\end{tabular}

\subsection{Domestic Hot Water}

Two natural-gas, tankless water heaters provide domestic hot water (DHW) for the kitchen and restrooms at the TTF, as shown in Figure 4-22. These units are natural gas fired and have an advertised thermal efficiency of $80 \%$. These heat-on-demand systems were selected because they reduce energy consumption by diminishing standby tank losses, which can be $15 \%$ to $20 \%$ of a conventional system.

\footnotetext{
${ }^{3}$ Measured with respect to the central lighting sensor. Does not represent the actual lighting level of the zone.
} 


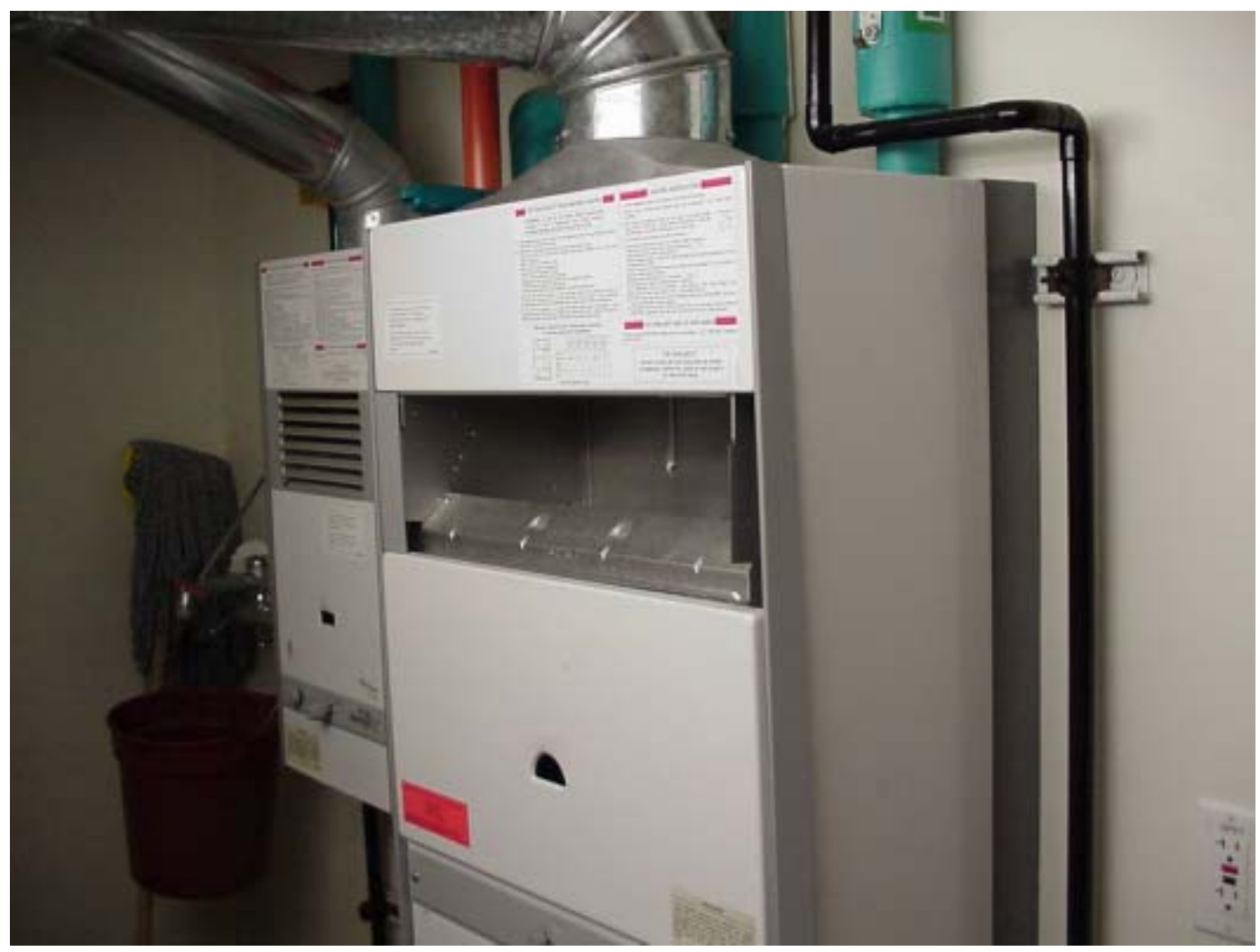

Figure 4-22 Tankless DHW heaters

\subsection{Predicted Energy Performance}

NREL used an energy model of the final design to ensure that the building design could be expected to meet goals for energy performance. The final design energy model represents the building, as described in Sections 4.2 through 4.8. The energy cost saving was determined by comparing the results of a final design model to the base-case reference model discussed in Section 3.3.1. To estimate heating energy costs associated with using hot water from NREL's central heating plant, natural gas boilers were simulated in both the final design and base-case reference models. The modeling predictions determined that the goal of reducing energy cost for $\mathrm{HVAC}+\mathrm{L}$ by $70 \%$ could be achieved. The predicted saving was $\$ 3,501 / \mathrm{yr}$, representing a $73 \%$ reduction in energy cost associated with $\mathrm{HVAC}+\mathrm{L}$.

Figure 4-23 shows a rendering of the final design model developed for DOE-2.1E. Table 4-7 summarizes results for energy use and cost by end use for both models. Figure 4-24 plots the cost results from Table 4-7. These energy costs accounted for operating the HVAC $+\mathrm{L}$ systems. Other energy uses associated with the building operation were equal in both models; these included plug loads of $0.75 \mathrm{~W} / \mathrm{ft}^{2}$ $\left(8.1 \mathrm{~W} / \mathrm{m}^{2}\right)$ with an annual cost of $\$ 1,389 / \mathrm{yr}$ and domestic hot-water heating of $1.8 \mathrm{kBtu} / \mathrm{ft}^{2} \cdot \mathrm{yr}(20.4$ $\left.\mathrm{MJ} / \mathrm{m}^{2} \cdot \mathrm{yr}\right)$ with an annual cost of $\$ 76 / \mathrm{yr}$. Exterior lights were $14.9 \mathrm{MMBtu} / \mathrm{yr}(15.7 \mathrm{GJ} / \mathrm{yr})$, with an annual cost of $\$ 282 / \mathrm{yr}$.

The site energy saving for the TTF differed from the energy cost saving because of the differences in price structure for electricity and natural gas. NREL calculated energy costs using an electricity cost of $\$ 0.0248 / \mathrm{kWh}$, with an on-peak demand charge of $\$ 6.15 / \mathrm{kW}$ and an off-peak demand charge of $\$ 3.75 / \mathrm{kW}$. This electric rate structure resulted in a virtual rate of $\$ 0.0645 / \mathrm{kWh}$. In equivalent energy units, the virtual electric rate of $\$ 18.90$ per million Btu's was significantly higher than the gas rate. Natural gas costs were \$3.85/MMBtu. When the lights were turned off, more load was placed on the heating system, 
so the low-energy design shifted energy use somewhat from electricity to gas. The predicted HVAC $+\mathrm{L}$ energy saving was $167 \mathrm{MMBtu} / \mathrm{yr}$ (49 MWh/yr), which represented a 57\% reduction.

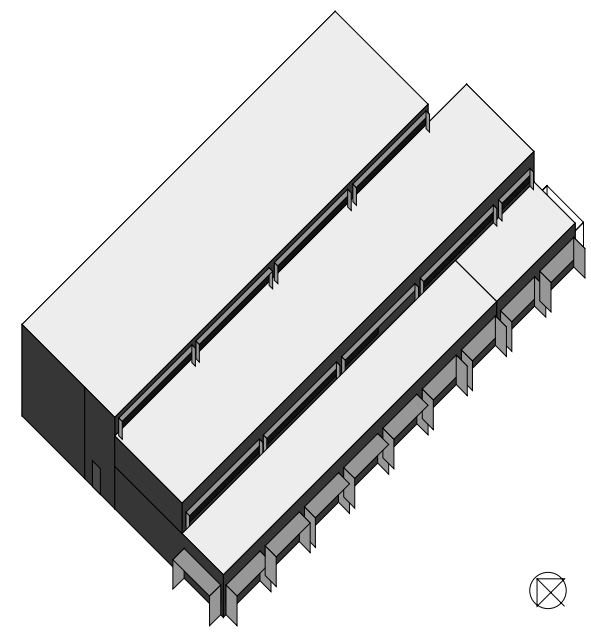

Figure 4-23 Rendering of the final design model

Table 4-7 Energy Use and Costs: Final Design Model versus Base-Case Model

\begin{tabular}{|c|c|c|c|c|c|}
\hline \multirow[b]{2}{*}{ End use } & \multicolumn{2}{|c|}{ Base-Case Model } & \multicolumn{2}{|c|}{ Final Design Model } & \multirow[b]{2}{*}{$\%$ savings } \\
\hline & $\begin{array}{c}\text { MMBtu/yr } \\
\text { (GJ/yr) }\end{array}$ & $\$ / y r$ & $\begin{array}{c}\text { MMBtu/yr } \\
\text { (GJ/yr) }\end{array}$ & $\$ / y r$ & \\
\hline Lights & $\begin{array}{c}199.5 \\
(210.5)\end{array}$ & $\$ 3,771$ & $\begin{array}{c}17.2 \\
(18.1)\end{array}$ & $\$ 804$ & $78.7 \%$ \\
\hline $\begin{array}{l}\text { Space } \\
\text { Heating }\end{array}$ & $\begin{array}{c}46.1 \\
(48.6)\end{array}$ & $\$ 177$ & $\begin{array}{l}68.9 \\
(72.7) \\
\end{array}$ & $\$ 265$ & $-49.7 \%$ \\
\hline $\begin{array}{l}\text { Space } \\
\text { Cooling }\end{array}$ & $\begin{array}{c}22.9 \\
(24.2) \\
\end{array}$ & $\$ 433$ & $\begin{array}{c}5.8 \\
(6.1)\end{array}$ & $\$ 109$ & $74.8 \%$ \\
\hline $\begin{array}{l}\text { Heat } \\
\text { Rejection }\end{array}$ & $\begin{array}{c}6.0 \\
(6.3)\end{array}$ & $\$ 113$ & $\begin{array}{c}0.0 \\
(0.0)\end{array}$ & $\$ 0$ & $100.0 \%$ \\
\hline Pumps & $\begin{array}{c}5.8 \\
(6.1)\end{array}$ & $\$ 110$ & $\begin{array}{c}1.3 \\
(1.4)\end{array}$ & $\$ 25$ & $77.3 \%$ \\
\hline Fans & $\begin{array}{c}10.5 \\
(11.1)\end{array}$ & $\$ 198$ & $\begin{array}{c}5.2 \\
(5.5)\end{array}$ & $\$ 98$ & $50.5 \%$ \\
\hline DHW & $\begin{array}{c}17.8 \\
(18.8)\end{array}$ & $\$ 76$ & $\begin{array}{c}17.8 \\
(18.8)\end{array}$ & $\$ 76$ & $0.0 \%$ \\
\hline $\begin{array}{l}\text { Exterior } \\
\text { Lights }\end{array}$ & $\begin{array}{c}14.9 \\
(15.7)\end{array}$ & $\$ 282$ & $\begin{array}{c}14.9 \\
(15.7)\end{array}$ & $\$ 282$ & $0.0 \%$ \\
\hline Plugs & $\begin{array}{l}73.5 \\
(77.5)\end{array}$ & $\$ 1,389$ & $\begin{array}{l}73.5 \\
(77.5)\end{array}$ & $\$ 1,389$ & $0.0 \%$ \\
\hline $\begin{array}{l}\text { Total w/o } \\
\text { Plugs, DHW, } \\
\text { and Exterior } \\
\text { Lighting }\end{array}$ & $\begin{array}{l}291.0 \\
(307.0)\end{array}$ & $\$ 4,802$ & $\begin{array}{c}124 \\
(130)\end{array}$ & $\$ 1,301$ & $\begin{array}{l}-57 \% \text { (energy) } \\
-73 \% \text { (cost) }\end{array}$ \\
\hline Total & $\begin{array}{c}397.2 \\
(419.0)\end{array}$ & $\$ 6,546$ & $\begin{array}{c}230.2 \\
(242.9)\end{array}$ & $\$ 3,045$ & $\begin{array}{l}-42 \% \text { (energy) } \\
-53 \% \text { (cost) }\end{array}$ \\
\hline
\end{tabular}




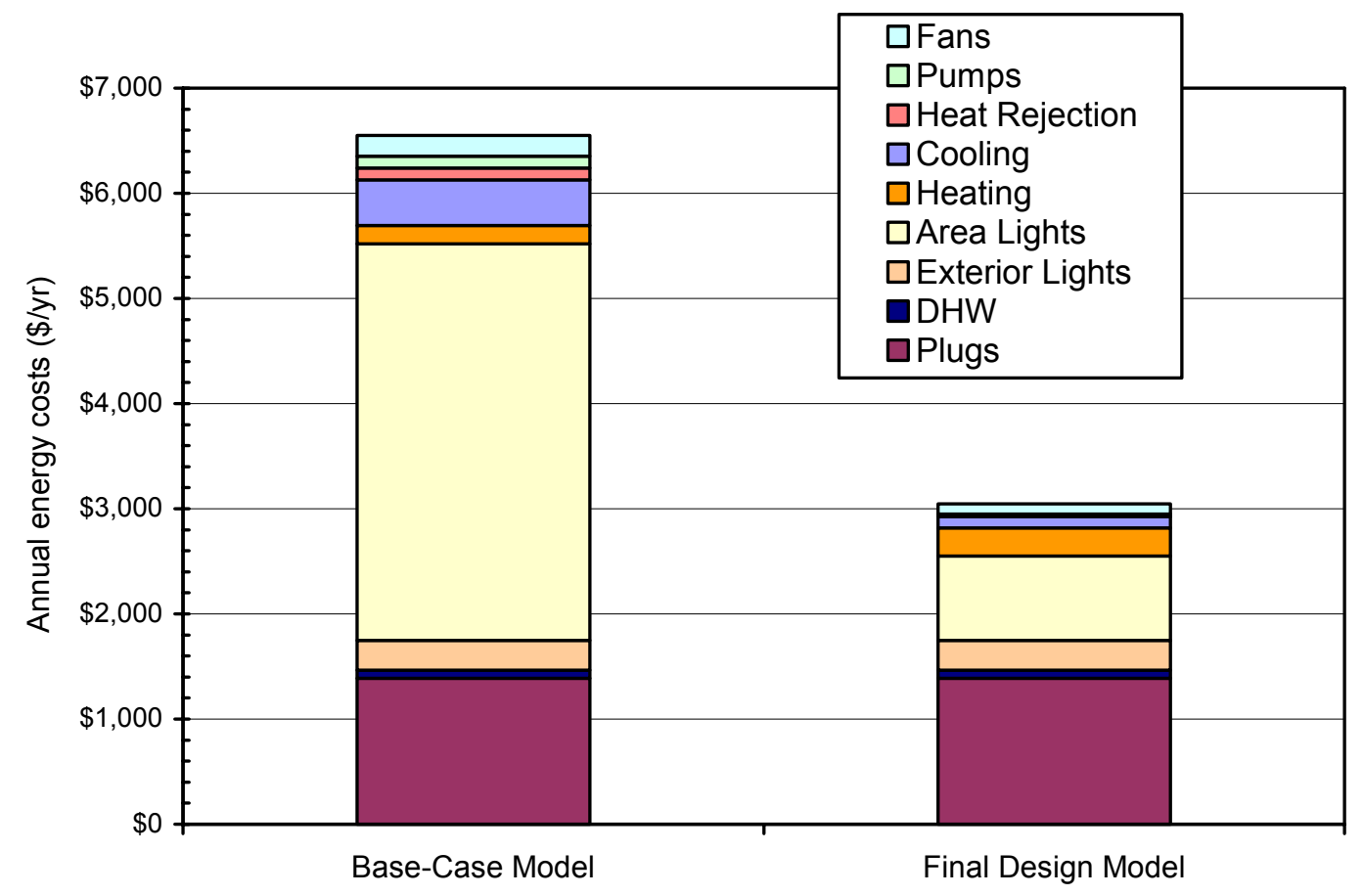

Figure 4-24 Summary of results for energy costs: final design model versus base-case model 


\section{Whole-Building Energy Evaluation}

This section presents an assessment of the TTF's energy performance after it was constructed, commissioned, occupied, and altered as described in Section 3.6. The analysis represents the building as described in Section 4. As the TTF became fully occupied, experiments such as battery charging research and desiccant equipment testing were added. Both of these loads have high-energy demands and affect the performance of the building.

\subsection{Whole-Building Evaluation Methodology}

The TTF is typical of many small buildings constructed today that range from light industrial to retail. The plug loads for these buildings are similar to the analysis performed and the results from this work, and the building design can be extended to these types of buildings. To extend value to an assortment of other buildings, the analysis used peak plug loads as defined in the base case of $0.75 \mathrm{~W} / \mathrm{ft}^{2}\left(8.1 \mathrm{~W} / \mathrm{m}^{2}\right)$. Because of the nature and evolution of the experiments in the building, the actual plug and process loads are highly unpredictable and not useful in evaluating the building.

Results of the analysis are based on computer models. NREL used the data collected from the building to calibrate those energy models and to provide results based on a typical weather year. This analysis provides long-term performance of the building based on actual data. Although overall energy performance is important, other related aspects warrant a more detailed analysis. These details are presented in subsequent sections, including occupant survey (Section 5.5), daylighting (Section 6.1), thermal comfort (Section 6.2), and economics (Section 7).

NREL calibrated the TTF computer models by systematically comparing collected energy data with simulated results. The models were calibrated by modifying the design model to represent the as-built condition of the building. Added to the models were actual data from lighting loads, plug loads, and schedules. NREL then compared the model results to actual data. Discrepancies were analyzed and the model was tuned until monthly end uses were within $12 \%$ of actual performance. Short-term tests were used to verify some parameters. These tests included blower door, tracer gas, and short-term energy monitoring (STEM). Calibration was done only when the desiccant and battery experiments were not running, as their sporadic behavior is not representative of buildings of this type.

This section summarizes the instrumentation NREL used to monitor and characterize the energy performance of the TTF. It presents the results of this monitoring effort and describes how researchers used the data to produce a calibrated energy model. The last part of this section discusses overall results including lighting, heating and cooling loads, HVAC system operation, and a comparison of the overall results when compared to national data.

\subsection{Whole-Building Monitoring}

The TTF monitoring system recorded detailed information that pertains to the building's energy performance for a period of one year after the final stages of commissioning and alterations. Because the TTF is a research test building for energy efficiency, it was equipped with far more sensing equipment than would normally be installed in a typical building. The sensing equipment aided NREL in monitoring the building; however, NREL can also use this equipment as an ongoing experiment to improve energy efficiency, comfort, and occupancy satisfaction within all future buildings. The EMS was used as a mechanism to collect and store data. The data were collected twice each day as the storage capacity of the EMS is limited. Additional points were added that were not part of the building controls. These points are listed in Table 5-1. 
Table 5-1 Additional Points Added to EMS for Building Monitoring

\begin{tabular}{|l|l|c|}
\hline \multicolumn{1}{|c|}{ Description } & \multicolumn{1}{c|}{ Input Signal Sensor Type } & Accuracy \\
\hline \hline Building Total Energy & Pulse point 1 pulse $=0.375 \mathrm{Wh}$ & $\pm 0.5 \%$ \\
\hline Lighting Energy & Pulse point 1 pulse $=0.375 \mathrm{Wh}$ & $\pm 0.5 \%$ \\
\hline HVAC Energy & Pulse point 1 pulse $=0.375 \mathrm{Wh}$ & $\pm 0.5 \%$ \\
\hline Plug Energy & Pulse point 1 pulse $=0.375 \mathrm{Wh}$ & $\pm 0.5 \%$ \\
\hline Building $\mathrm{CO}_{2}$ & 4-20 mA; nondispersive infrared & $\pm 5 \%$ \\
\hline Hot-Water Flow Meter & Turbine meter; high speed pulses & $\pm 1.5 \%$ \\
\hline
\end{tabular}

The TTF uses hot water from NREL's district heating plant to condition the building during the winter. The rate of heating energy used is determined by measuring the hot-water flow rate and fluid temperatures at the inlet and outlet and calculating heat flow rate using,

$$
\dot{Q}=\rho c_{p} \dot{V}\left(T_{\text {exit }}-T_{\text {in }}\right)
$$

where

$$
\begin{array}{ll}
\dot{Q} & =\text { heat flow rate } \\
\rho & =\text { density of hot water } \\
c_{p} & =\text { specific heat of hot water } \\
\dot{V} & =\text { volume flow rate of hot water } \\
T_{\text {exit }} & =\text { Temperature of hot-water loop leaving building } \\
T_{i n} & =\text { Temperature of hot-water loop entering building. }
\end{array}
$$

NREL's method of measuring heating energy use for the central system was checked for systematic errors by performing a first law comparison between heat removed from the hot-water supply and heat added to the supply air during pseudo steady-state tests. NREL selected a cold winter day, just before dawn, as a period that offers the closest approximation to steady-state conditions. This time also offers a large indoor-to-outdoor temperature difference and minimizes effects from solar radiation. The building was first cooled down for 30 minutes by forcing the main air handler to deliver its maximum rated flow of $9,680 \mathrm{cfm}(4,568 \mathrm{~L} / \mathrm{s})$ without heating the outdoor air and with economizer dampers fully open. A $30-$ minute time period was chosen to achieve near steady-state conditions within the AHU, resulting in a final discharge air temperature of $60^{\circ} \mathrm{F}\left(16^{\circ} \mathrm{C}\right)$. The AHU was then forced to provide a full flow rate of conditioned, $100 \%$ outdoor air at a discharge air temperature of $70^{\circ} \mathrm{F}\left(21^{\circ} \mathrm{C}\right)$. Measurements for computing data for total energy were collected over a 45-minute test period. NREL determined that steady-state conditions were reached when the hot water valve position and the discharge air temperature stabilized (temperature stabilized at $70^{\circ} \mathrm{F}\left(21^{\circ} \mathrm{C}\right)$ ). The air-side energy use was computed using Equation 1 with air as the working fluid.

Table 5-2 lists calculated results for air and water energy use. These results were found to be within $1.0 \%$. Test results provide confidence in the method of measuring heating energy for the central hot water system. However, it should be noted that this level of agreement is probably fortuitous because of the difficulties in accurately measuring temperatures and flow rates on the air side. 
Table 5-2 Heat Meter Accuracy Verification

\begin{tabular}{|l|l|}
\hline \multicolumn{2}{|c|}{ Heat Flow Meter Test Results } \\
\hline Water side calculation & $83,900 \mathrm{Btu}(88,514 \mathrm{~kJ})$ \\
\hline Air side calculation & $84,633 \mathrm{Btu}(89,288 \mathrm{~kJ})$ \\
\hline Percent difference & $-1.0 \%$ \\
\hline
\end{tabular}

\subsubsection{Data Collection}

The EMS could store only a very limited amount of information. Most EMS systems are designed to collect information, process, and control on an instantaneous basis. Information was collected from the EMS via a PC twice daily. A separate program on the PC was written to periodically compile the files into single monthly text files containing all recorded information.

The first phase of data collection began in April 1997 and ended in January 1998. Ten months of data were recorded before extensive analysis began. This second phase of data collection was between February 1998 and December 1999.

NREL encountered problems with the long-term data collection system. As the EMS could not store large quantities of information, the personal computer was responsible for collecting information from the EMS. The Windows ${ }^{\mathrm{TM}}$ Operating System was not stable enough to maintain long-term reliability. As a result, some data were lost. The conclusion is that monitoring systems should be designed for long-term data storage and should be independent of the EMS.

\subsection{Development of Building Energy Models}

Computer simulation models are essential to designing low-energy buildings. The design team created building models of the TTF during the design development phase as described in Section 3.3. Energy models can also provide a means of quantifying the energy performance and savings after a building is occupied.

The TTF is a research laboratory where experiments are constantly being constructed, conducted, altered and torn down to meet the changing needs of research activities. Some experiments have set running times; others may operate more stochastically. In addition, some experiments release large internal loads; others have little net-effect. The Desiccant Test Loop is an example of this dynamic environment, having the capacity to release more than $300 \mathrm{~kW}$ of sensible heat and $40 \mathrm{lb} / \mathrm{h}(18.1 \mathrm{~kg} / \mathrm{h})$ of water into the TTF interior. This capacity was somewhat reduced at the end of May 1998 by ducting the regeneration air back to the outdoors; however, the supply air produced by this loop is still released within the building. This supply air can be very warm and humid, depending on the particular test.

The experiments in the building create a dynamic environmental nature within the TTF that is not typical of buildings. As a result, actual data are used to define schedules and then simulation results are calibrated against actual performance. Annual results are based on simulation from the calibrated models. Figure 5-1 shows a flow chart of how the measured data were used to calibrate the as-built model and the base-case model, as well as how the energy cost saving, the site energy saving, and the source energy saving were calculated. The results presented are representative of a building of this size with set plug loads. This information will be more useful to show how small commercial buildings can be designed to minimize energy consumption. 


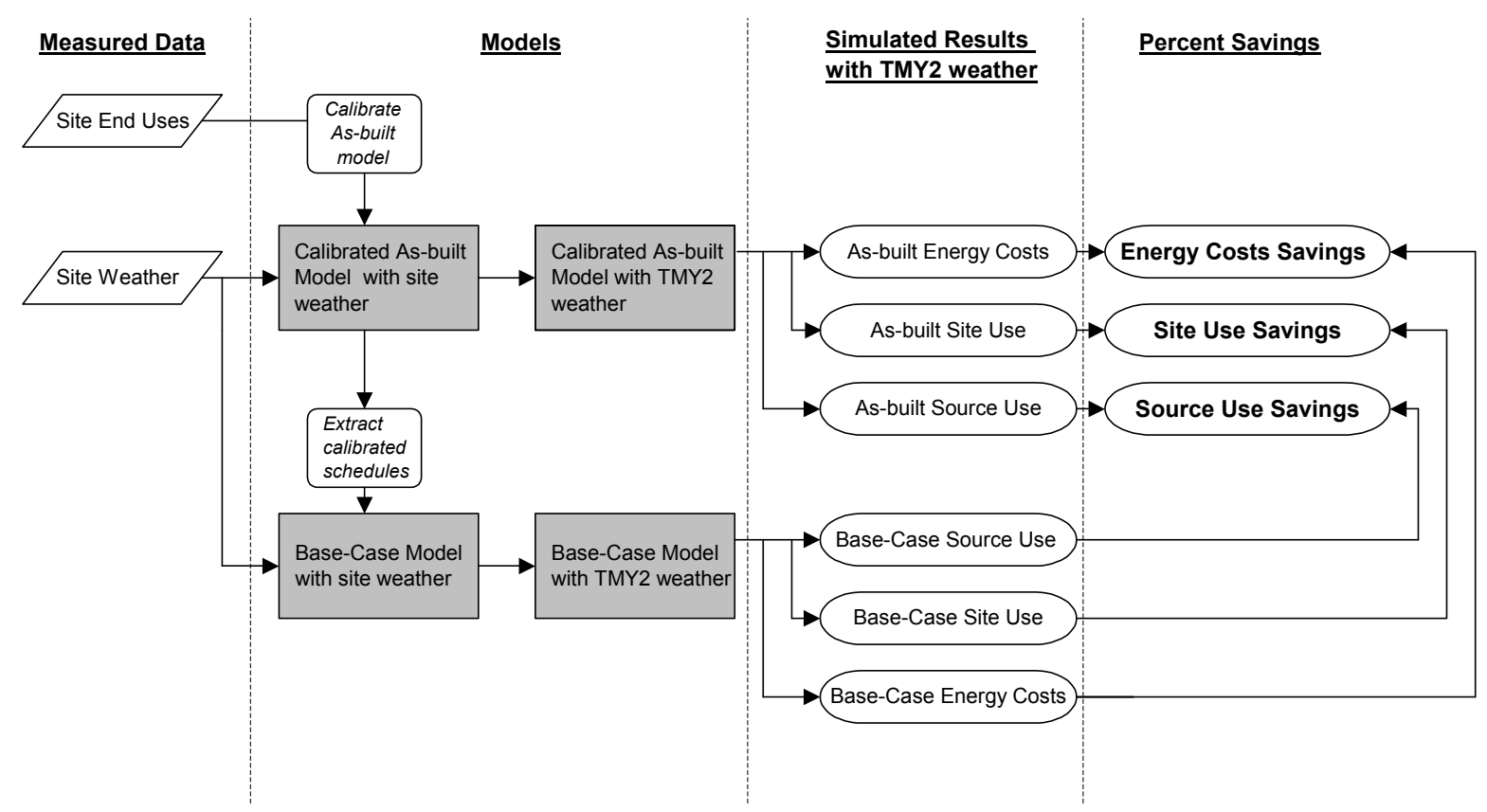

Figure 5-1 Whole-building evaluation flow chart

The as-built model was calibrated using portions of actual weather data coupled with actual measurements. To provide a saving level that is normalized to the weather for a typical year, rather than the atypical weather used in the calibration, both models were rerun using typical weather data to provide a better prediction of long-term operational averages. The days in which the TTF was occupied and experienced typical office building loads were selected for the calibration process. These characteristics include typical internal loads (e.g., PCs, fax machines, and copiers), schedules ( 8 a.m. to 5 p.m., 5 days per week), and HVAC set points. Calibrating the models with characteristic data permitted an unbiased comparison with the base-case model. Note that schedules and set points are the same for the base-case model and the as-built model.

The calibration process used both the base-case and as-built models that were created during the designdevelopment phase (Section 3.3). Table 3-2 summarizes the original base-case model that complied with Federal Energy Code 10 CFR 435-1995. The following sections describe the data used to calibrate the simulation.

\subsubsection{Weather Data}

For design analysis, energy models use TMY2 weather data (NREL 1995). These data represent typical metrological years based on 30-years of weather data. However, actual weather data are needed to compare to measured energy data. Table 5-3 lists data collected by NREL's Solar Radiation Research Laboratory that were used for calibrated models. This site is located less than 200 yards from the building and provides research quality data for programs at NREL. These data were collected and processed into a TMY2-format weather data file. This weather file was used to calibrate the energy models for the building as the weather data were for the same period as the collected data from the building. 
Table 5-3 Weather Data Collected for Calibrated Energy Models

\begin{tabular}{|c|c|}
\hline Weather Data & Units \\
\hline \hline Direct Normal Radiation & $\mathrm{kJ} / \mathrm{m}^{2}$ \\
\hline Total Horizontal Radiation & $\mathrm{kJ} / \mathrm{m}^{2}$ \\
\hline Atmospheric Pressure & Tenths of mbars \\
\hline Dry-bulb Temperature & Tenths of ${ }^{\circ} \mathrm{C}$ \\
\hline Dew-point Temperature & Tenths of ${ }^{\circ} \mathrm{C}$ \\
\hline Wind Direction & Degrees clockwise from North \\
\hline Wind Speed & Tenths of $\mathrm{m} / \mathrm{s}$ \\
\hline
\end{tabular}

\subsubsection{Infiltration}

NREL determined the infiltration rates for the TTF using a tracer-gas analysis. Data collected were compared to the simulated results to ensure that models properly accounted for infiltration. A gas concentration meter was used to monitor the change in tracer gas concentrations over the chosen test period. The multi-gas meter automatically calculated the infiltration rate as concentrations of the tracer gas diminished. The tracer gas used in this analysis was sulfur hexafluoride $\left(\mathrm{SF}_{6}\right)$. The ceiling fans were left operating to improve mixing of tracer gas and building air. All other HVAC components were turned off, and building exits were checked for proper closure.

The tracer-gas test results indicated the TTF had an infiltration rate of $0.1 \mathrm{ACH}$, with results shown in Figure 5-2. The ACH result demonstrates that a relatively tight building was constructed, as was intended in the design. The assumption that no infiltration occurs during occupied hours can be made because positive building pressure results from operation of the HVAC system. Measured infiltration is expected to occur at night and on weekends when the HVAC systems are shut down. The TTF's volumetric flow rate of outdoor air was calculated at $270 \mathrm{cfm}(127.4 \mathrm{~L} / \mathrm{s})$ without any fans operating.

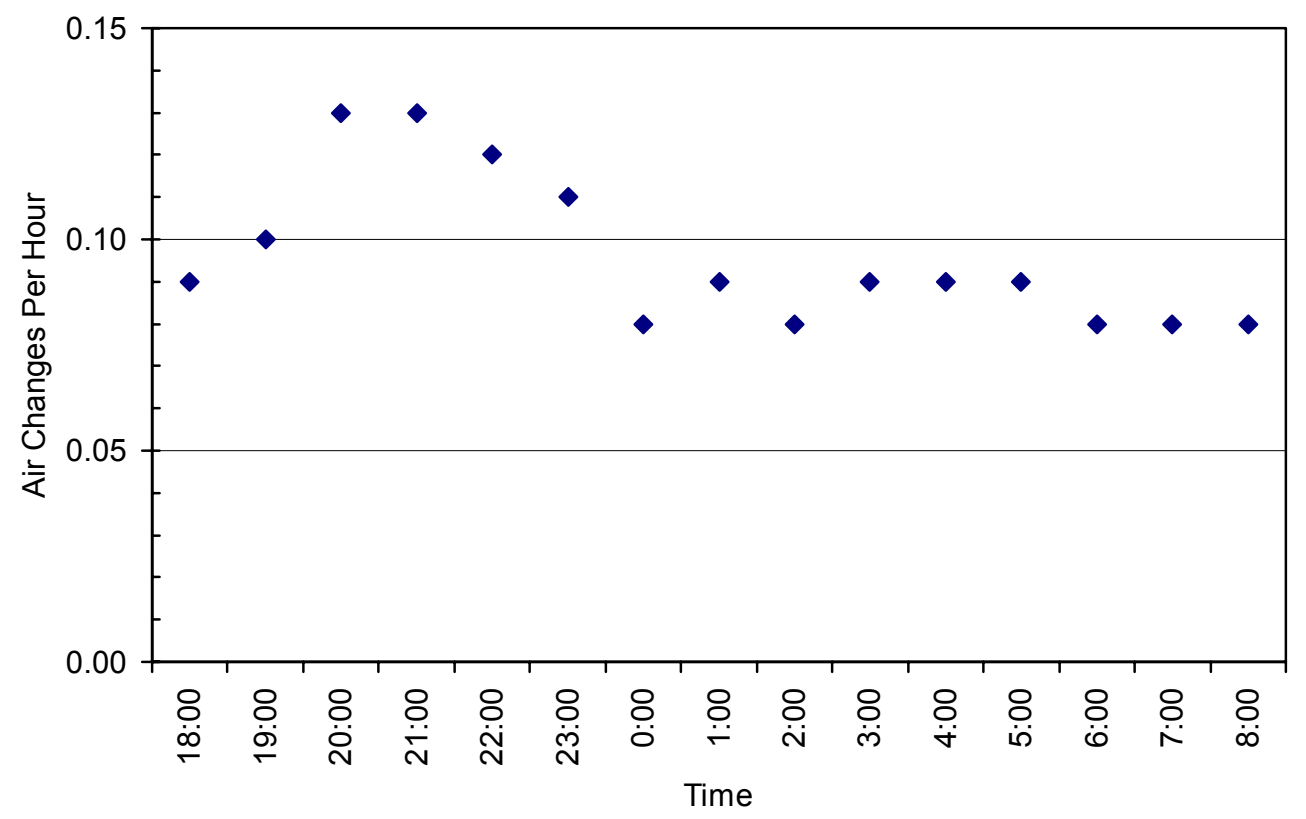

Figure 5-2 Results from tracer gas measurement of infiltration rate 


\subsubsection{Short-Term Energy Monitoring}

A STEM test was performed as part of the thermal performance of the TTF (Balcomb et al. 1990). The STEM analysis produces information needed to accurately extrapolate annual building performance results from data collected over a short time (usually 4 days). One of the results generated by the STEM test is the building load coefficient (BLC), an indicator of the building's overall heat transfer as a simple coefficient defined in Equation 2, where,

$$
B L C=\frac{\dot{Q}}{\left(T_{d b, O A}-T_{d b, i n}\right)}
$$

where,

$$
\begin{array}{ll}
T_{d b, O A} & =\text { dry-bulb outdoor air temperature } \\
T_{d b, \text { in }} & =\text { dry-bulb of indoor air temperature } \\
\dot{Q} & =\text { net heat flux out of the building }
\end{array}
$$

Figure 5-3 shows a sample of the results; the average of BLC was determined to be $2.9 \mathrm{kBtu} / \mathrm{h} \cdot{ }^{\circ} \mathrm{F}$ $(1,530 \mathrm{~W} / \mathrm{K})$. STEM test results show that the actual BLC was higher than the BLC originally predicted by SERI-RES. It is expected that differences between the building design and how it was actually constructed caused the difference (Table 3-4).

Table 5-4 lists the results after revising the building model to better represent the as-built situation. The BLC predicted by SERI-RES was within $1 \%$ of the measured BLC showing excellent correlation between the predicted thermal model and the actual performance of the building.

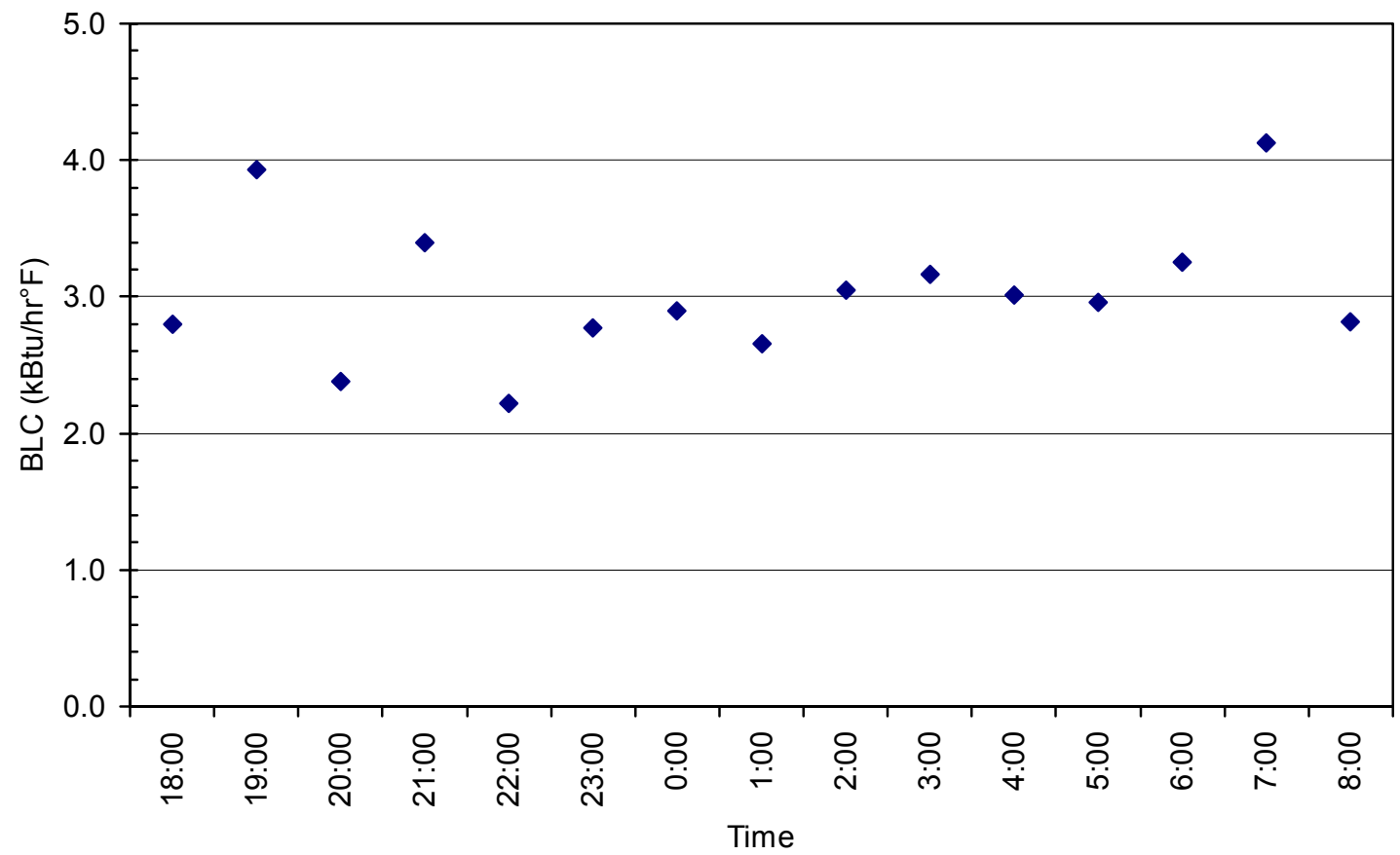

Figure 5-3 STEM results for the BLC 


\begin{tabular}{|l|c|c|c|}
\hline & \multicolumn{2}{|c|}{ Building Load Coefficient } & \multirow{2}{*}{$\begin{array}{c}\text { Percent } \\
\text { Difference }\end{array}$} \\
\cline { 2 - 3 } & Btu/h$\cdot{ }^{\circ} \mathrm{F}$ & $\mathrm{W} / \mathrm{K}$ & \multirow{2}{*}{$+1 \%$} \\
\hline \hline As-Built Model Predicted BLC & 2,938 & 1,550 & \\
\hline Measured BLC (average) & 2,900 & 1,530 & \\
\hline
\end{tabular}

\subsubsection{Lighting Calibration}

NREL calibrated the modeled lighting system parameters against actual observed use patterns of the lights. Lighting level set points were adjusted in the model such that the daylighting results matched the actual lighting performance of the building. Figure 5-4 compares results for lighting system energy use from the calibrated model and measurements. This accounts for differences between the location of the sensor (ceiling mounted) and the location of the lighting sensors in the simulations. It also accounts for simplifications of the daylighting models compared with actual lighting physics.

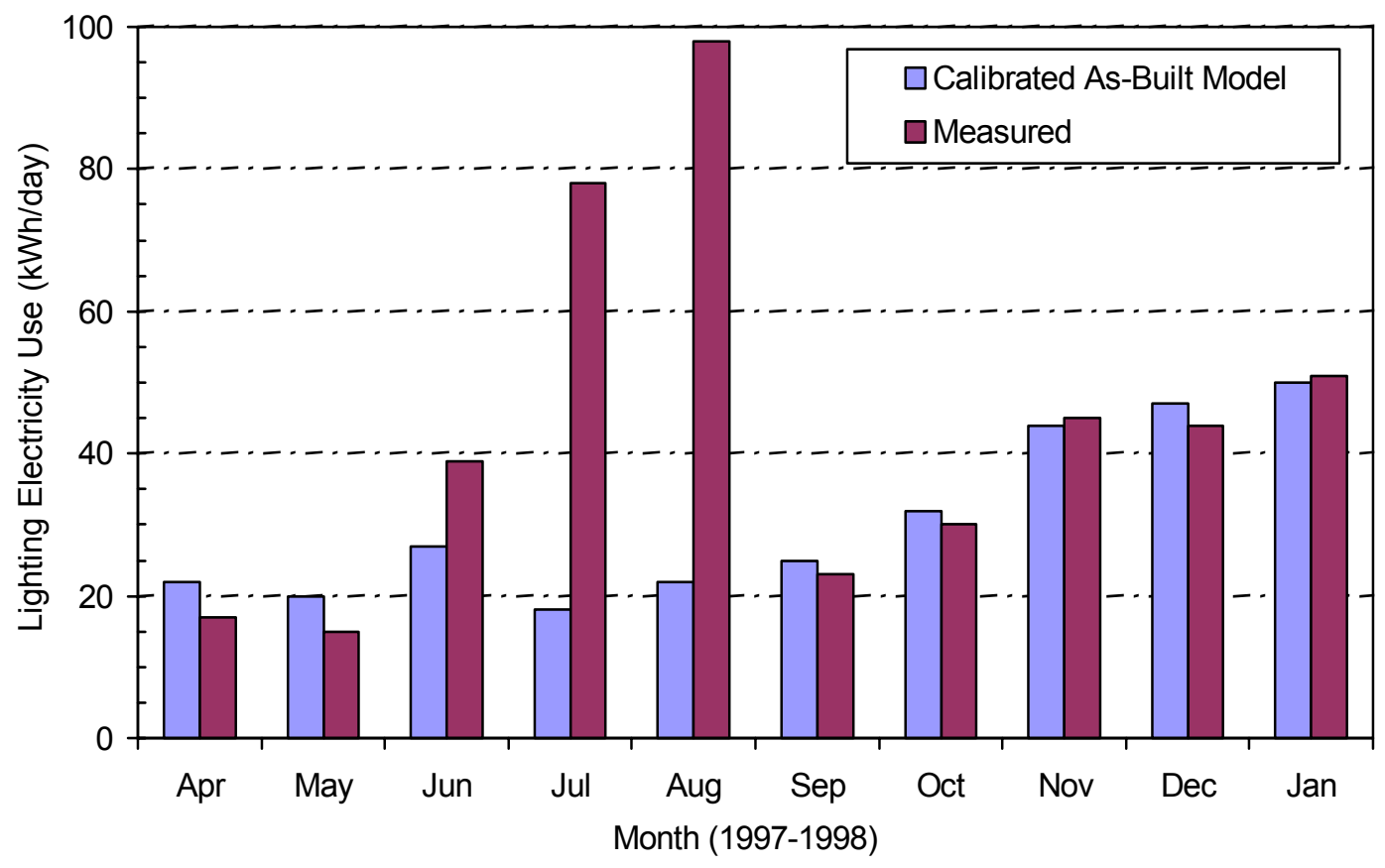

Figure 5-4 Lighting system calibration results

During the months of June, July, and August 1997, controls were being adjusted and the lights were left on much of the time - this was not a normal operation for the building. The result is that these months were not used for calibration purposes, as they do not represent the operation of the building under typical operating patterns. The calibrated lighting loads in the model were much less than actual measured use for these months. Excluding these months, the lighting energy used in calibrated model predictions was within $7 \%$ of the actual measured use. Modeled lighting loads tend to be slightly higher than actual measured data because motion sensors turn lights off and this erratic effect is difficult to account for using conventional schedules for modeling occupancy. Intermittent use of the central core rooms (restrooms and kitchen) also accounts for part of these differences. The fact that the daylighting system is functioning well is demonstrated by observing the lower energy consumption during the months of September and October as compared to November through January. 


\subsubsection{HVAC system}

NREL adjusted the zone set points, HVAC equipment, schedules, and power loads based on measured data and the as-built drawings. Figure 5-5 presents results for heating energy from the calibrated model and measurement of the district hot-water energy. Figure 5-6 presents results for electricity used for the HVAC system from the calibrated model and measured electricity consumption. NREL considers a building simulation to be calibrated when the simulated monthly energy use is within $\pm 12 \%$ of the measured monthly energy use (Energy Simulation Specialists, Inc. 1995).

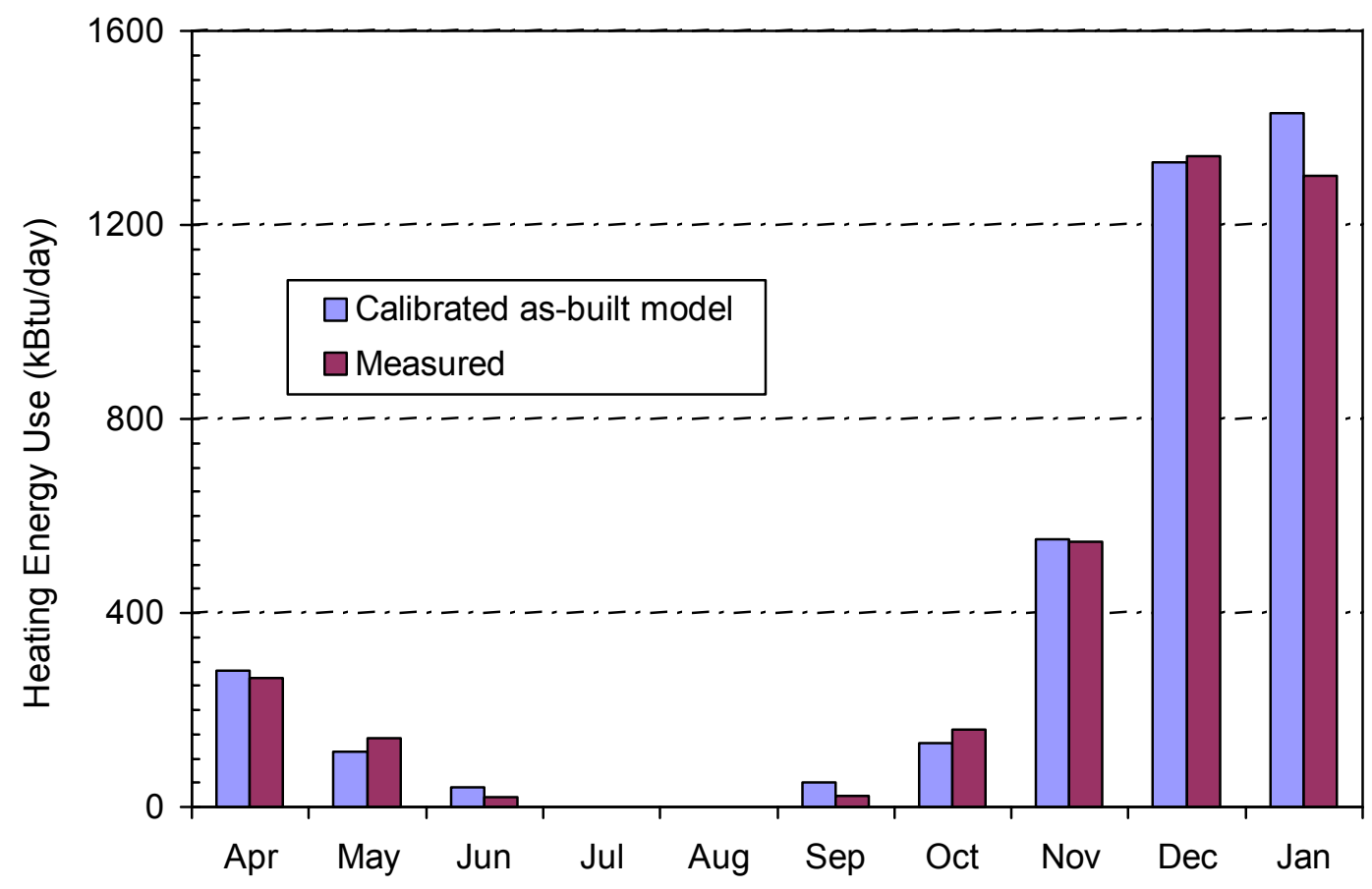

Figure 5-5 Comparison of calibrated model versus actual measurements for building heating energy 


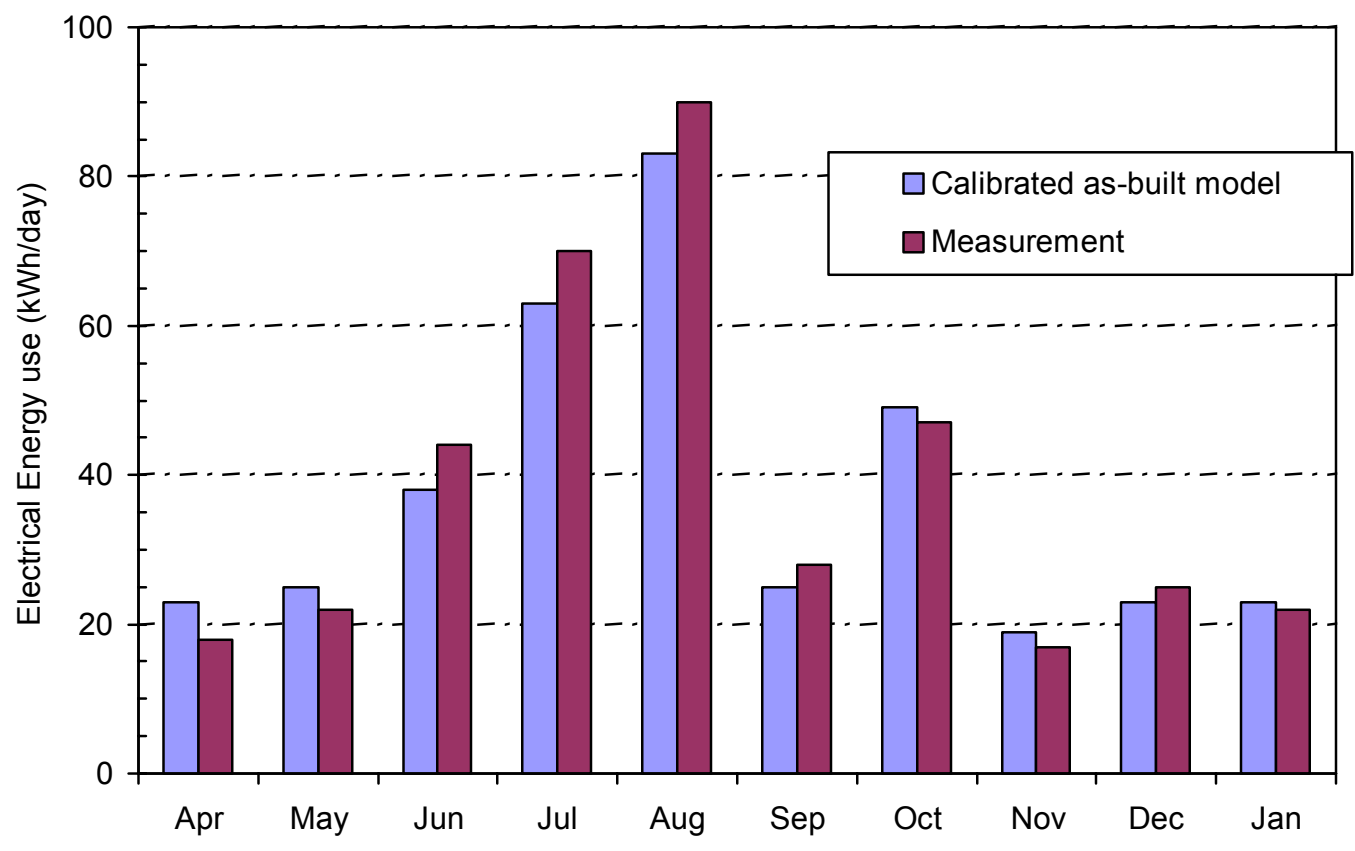

Figure 5-6 Results for HVAC system electricity energy use: calibrated model versus measurement

\subsubsection{Model Summary}

The original models developed during design analysis were adjusted to better reflect the building as it was built and operated. The as-built model reflects actual construction and calibration to actual data. This model also reflects actual schedules in the building. The base-case model was modified to reflect the same set points and schedules as the as-built model. Table 5-5 presents a summary of the four models: original base case, final design, calibrated base case, and as-built.

A forced minimum ventilation rate of $15 \mathrm{cfm} /$ person $(7 \mathrm{~L} / \mathrm{s} /$ person) was assigned during occupied hours. Occupancy, temperature, equipment set points, and schedules were based on actual measured data and made identical in both the base-case and as-built models. Both the base-case and as-built models operated the fans only when heating and cooling was required. However, the default factory setting is to operate these fans for all occupied hours. 
Table 5-5

Summary Calibration of the Base-Case and As-Built Energy Models

\begin{tabular}{|c|c|c|c|c|c|c|c|c|}
\hline Model Property & \multicolumn{2}{|c|}{ Original Base-Case Model } & \multicolumn{2}{|c|}{ Final Design Model } & \multicolumn{2}{|c|}{$\begin{array}{c}\text { Calibrated Base-Case } \\
\text { Model }\end{array}$} & \multicolumn{2}{|c|}{ As-Built Model } \\
\hline $\begin{array}{l}\text { Office Occupancy Schedule [M-F] } \\
\text { Office Occupancy Schedule [SSH] }\end{array}$ & $\begin{array}{l}0-7 \\
7-8 \\
8-17 \\
17-18 \\
18-24 \\
0-24\end{array}$ & $\begin{array}{l}0 \% \\
50 \% \\
100 \% \\
50 \% \\
0 \% \\
0 \%\end{array}$ & $\begin{array}{l}0-7 \\
7-8 \\
8-17 \\
17-18 \\
18-24 \\
0-24\end{array}$ & $\begin{array}{l}0 \% \\
50 \% \\
100 \% \\
50 \% \\
0 \% \\
0 \%\end{array}$ & $\begin{array}{l}0-7 \\
7-8 \\
8-17 \\
17-18 \\
18-21 \\
21-24 \\
0-24\end{array}$ & $\begin{array}{l}0 \% \\
50 \% \\
100 \% \\
50 \% \\
10 \% \\
0 \% \\
0 \%\end{array}$ & $\begin{array}{l}0-7 \\
7-8 \\
8-17 \\
17-18 \\
18-21 \\
21-24 \\
0-24\end{array}$ & $\begin{array}{l}0 \% \\
50 \% \\
100 \% \\
50 \% \\
10 \% \\
0 \% \\
0 \%\end{array}$ \\
\hline $\begin{array}{l}\text { Lab Occupancy Schedule [M-F] } \\
\text { Lab Occupancy Schedule [SSH] }\end{array}$ & $\begin{array}{l}0-6 \\
6-7 \\
7-18 \\
18-19 \\
19-24 \\
0-24\end{array}$ & $\begin{array}{l}0 \% \\
50 \% \\
100 \% \\
50 \% \\
0 \% \\
0 \%\end{array}$ & $\begin{array}{l}0-6 \\
6-7 \\
7-18 \\
18-19 \\
19-24 \\
0-24\end{array}$ & $\begin{array}{l}0 \% \\
50 \% \\
100 \% \\
50 \% \\
0 \% \\
0 \%\end{array}$ & $\begin{array}{l}0-6 \\
6-7 \\
7-18 \\
18-19 \\
19-21 \\
21-24 \\
0-24\end{array}$ & $\begin{array}{l}0 \% \\
50 \% \\
100 \% \\
50 \% \\
10 \% \\
0 \% \\
0 \%\end{array}$ & $\begin{array}{l}0-6 \\
6-7 \\
7-18 \\
18-19 \\
19-21 \\
21-24 \\
0-24\end{array}$ & $\begin{array}{l}0 \% \\
50 \% \\
100 \% \\
50 \% \\
10 \% \\
0 \% \\
0 \%\end{array}$ \\
\hline $\begin{array}{l}\text { Conference Occupancy Schedule } \\
\text { [M-F] }\end{array}$ & None & & None & & $\begin{array}{l}0-7 \\
7-18 \\
19-24\end{array}$ & $\begin{array}{l}0 \% \\
25 \% \\
0 \%\end{array}$ & $\begin{array}{l}0-7 \\
7-18 \\
19-24\end{array}$ & $\begin{array}{l}0 \% \\
25 \% \\
0 \%\end{array}$ \\
\hline Conference Occupancy Schedule [SSH] & None & & None & & $0-24$ & $0 \%$ & $0-24$ & $0 \%$ \\
\hline $\begin{array}{l}\text { Lighting Schedule [M-F] } \\
\text { Lighting Schedule [SSH] }\end{array}$ & $\begin{array}{l}0-7 \\
7-18 \\
18-24 \\
0-24\end{array}$ & $\begin{array}{l}10 \% \\
100 \% \\
10 \% \\
10 \%\end{array}$ & $\begin{array}{l}0-7 \\
7-18 \\
18-24 \\
0-24\end{array}$ & $\begin{array}{l}10 \% \\
100 \% \\
10 \% \\
10 \%\end{array}$ & $\begin{array}{l}0-7 \\
7-18 \\
18-21 \\
21-24 \\
0-24\end{array}$ & $\begin{array}{l}10 \% \\
100 \% \\
50 \% \\
10 \% \\
10 \%\end{array}$ & $\begin{array}{l}0-7 \\
7-18 \\
18-21 \\
21-24 \\
0-24\end{array}$ & $\begin{array}{l}10 \% \\
100 \% \\
50 \% \\
10 \% \\
10 \%\end{array}$ \\
\hline Average Lighting Density & \multicolumn{2}{|c|}{$1.5 \mathrm{~W} / \mathrm{ft}^{2}\left(15.1 \mathrm{~W} / \mathrm{m}^{2}\right)$} & \multicolumn{2}{|c|}{$0.7 \mathrm{~W} / \mathrm{ft}^{2}\left(7.5 \mathrm{~W} / \mathrm{m}^{2}\right)$} & \multicolumn{2}{|c|}{$1.5 \mathrm{~W} / \mathrm{ft}^{2}\left(15.1 \mathrm{~W} / \mathrm{m}^{2}\right)$} & \multicolumn{2}{|c|}{$0.8 \mathrm{~W} / \mathrm{ft}^{2}\left(8.6 \mathrm{~W} / \mathrm{m}^{2}\right)$} \\
\hline Lighting Control Steps & \multicolumn{2}{|c|}{ No Daylighting } & \multicolumn{2}{|c|}{ On/50\%/Off } & \multicolumn{2}{|c|}{ No Daylighting } & \multicolumn{2}{|l|}{ On/Off } \\
\hline Daylighting Set Point & \multicolumn{2}{|l|}{ None } & \multicolumn{2}{|c|}{20 fc (215 Lux) } & \multicolumn{2}{|l|}{ None } & \multicolumn{2}{|c|}{35 fc (377 Lux) } \\
\hline Office Daylight Sensor Location & \multicolumn{2}{|l|}{ None } & \multicolumn{2}{|c|}{$\begin{array}{l}60 \mathrm{ft} \text { from the east wall, } 16 \mathrm{ft} \\
\text { from the south wall, } 2.5 \mathrm{ft} \text { high } \\
(18.3,4.9,0.8 \mathrm{~m})\end{array}$} & \multicolumn{2}{|l|}{ None } & \multicolumn{2}{|c|}{$\begin{array}{l}60 \mathrm{ft} \text { from the east wall, } 8 \mathrm{ft} \text { from the } \\
\text { south wall, } 2.5 \mathrm{ft} \text { high } \\
(18.3,2.4,0.8 \mathrm{~m})\end{array}$} \\
\hline Infiltration & \multicolumn{2}{|c|}{$0.25 \mathrm{ACH}$} & \multicolumn{2}{|c|}{$0.25 \mathrm{ACH}$} & \multicolumn{2}{|l|}{$0.25 \mathrm{ACH}$} & \multicolumn{2}{|c|}{$0.10 \mathrm{ACH}$} \\
\hline Separate Conference Room Zone & \multicolumn{2}{|l|}{ No } & \multicolumn{2}{|l|}{ No } & \multicolumn{2}{|l|}{ Yes } & \multicolumn{2}{|l|}{ Yes } \\
\hline $\begin{array}{l}\text { Heating Schedule [M-F] } \\
\text { Heating Schedule [SSH] }\end{array}$ & $\begin{array}{l}0-7 \\
7-17 \\
17-24 \\
0-24 \\
\end{array}$ & $\begin{array}{l}60^{\circ} \mathrm{F} / 15.6^{\circ} \mathrm{C} \\
70^{\circ} \mathrm{F} / 21.1^{\circ} \mathrm{C} \\
60^{\circ} \mathrm{F} / 15.6^{\circ} \mathrm{C} \\
60^{\circ} \mathrm{F} 15.6^{\circ} \mathrm{C}\end{array}$ & $\begin{array}{l}0-7 \\
7-17 \\
17-24 \\
0-24 \\
\end{array}$ & $\begin{array}{l}60^{\circ} \mathrm{F} / 15.6^{\circ} \mathrm{C} \\
72^{\circ} \mathrm{F} / 21.1^{\circ} \mathrm{C} \\
60^{\circ} \mathrm{F} / 15.6^{\circ} \mathrm{C} \\
60^{\circ} \mathrm{F} / 15.6^{\circ} \mathrm{C}\end{array}$ & $\begin{array}{l}0-6 \\
6-18 \\
18-24 \\
0-24\end{array}$ & $\begin{array}{l}55^{\circ} \mathrm{F} / 12.8^{\circ} \mathrm{C} \\
72^{\circ} \mathrm{F} / 22.2^{\circ} \mathrm{C} \\
55^{\circ} \mathrm{F} / 12.8^{\circ} \mathrm{C} \\
55^{\circ} \mathrm{F} / 12.8^{\circ} \mathrm{C}\end{array}$ & $\begin{array}{l}0-6 \\
6-18 \\
18-24 \\
0-24\end{array}$ & $\begin{array}{l}55^{\circ} \mathrm{F} / 12.8^{\circ} \mathrm{C} \\
72^{\circ} \mathrm{F} / 22.2^{\circ} \mathrm{C} \\
55^{\circ} \mathrm{F} / 12.8^{\circ} \mathrm{C} \\
5^{\circ} \mathrm{F} / 12.8^{\circ} \mathrm{C}\end{array}$ \\
\hline $\begin{array}{l}\text { Cooling Schedule [M-F] } \\
\text { Cooling Schedule [SSH] }\end{array}$ & $\begin{array}{l}0-7 \\
7-17 \\
17-24 \\
0-24 \\
\end{array}$ & $\begin{array}{l}88^{\circ} \mathrm{F} / 31.1^{\circ} \mathrm{C} \\
78^{\circ} \mathrm{F} / 25.6^{\circ} \mathrm{C} \\
88^{\circ} \mathrm{F} / 31.1^{\circ} \mathrm{C} \\
88^{\circ} \mathrm{F} / 31.1^{\circ} \mathrm{C} \\
\end{array}$ & $\begin{array}{l}0-7 \\
7-17 \\
17-24 \\
0-24 \\
\end{array}$ & $\begin{array}{l}88^{\circ} \mathrm{F} / 31.1^{\circ} \mathrm{C} \\
78^{\circ} \mathrm{F} / 25.6^{\circ} \mathrm{C} \\
88^{\circ} \mathrm{F} / 31.1^{\circ} \mathrm{C} \\
88^{\circ} \mathrm{F} / 31.1^{\circ} \mathrm{C} \\
\end{array}$ & $\begin{array}{l}0-6 \\
6-18 \\
18-24 \\
0-24 \\
\end{array}$ & $\begin{array}{l}88^{\circ} \mathrm{F} / 31^{\circ} \mathrm{C} \\
76^{\circ} \mathrm{F} / 24.4^{\circ} \mathrm{C} \\
88^{\circ} \mathrm{F} / 31^{\circ} \mathrm{C} \\
88^{\circ} \mathrm{F} / 31^{\circ} \mathrm{C} \\
\end{array}$ & $\begin{array}{l}0-6 \\
6-18 \\
18-24 \\
0-24 \\
\end{array}$ & $\begin{array}{l}88^{\circ} \mathrm{F} / 31^{\circ} \mathrm{C} \\
76^{\circ} \mathrm{F} / 24.4^{\circ} \mathrm{C} \\
88^{\circ} \mathrm{F} / 31^{\circ} \mathrm{C} \\
88^{\circ} \mathrm{F} / 31^{\circ} \mathrm{C} \\
\end{array}$ \\
\hline Design Cooling Temperature & \multicolumn{2}{|c|}{$78^{\circ} \mathrm{F}\left(25.6^{\circ} \mathrm{C}\right)$} & \multicolumn{2}{|c|}{$78^{\circ} \mathrm{F}\left(25.6^{\circ} \mathrm{C}\right)$} & \multicolumn{2}{|c|}{$76^{\circ} \mathrm{F}\left(24.4^{\circ} \mathrm{C}\right)$} & \multicolumn{2}{|c|}{$76^{\circ} \mathrm{F}\left(24.4^{\circ} \mathrm{C}\right)$} \\
\hline Shading Schedule Transmission & $1 / 1-12 / 3$ & $20 \%$ & $1 / 1-12 / 3$ & $20 \%$ & $\begin{array}{l}1 / 1-2 / 28 \\
3 / 1-10 / 31 \\
11 / 1-12 / 31\end{array}$ & $\begin{array}{l}80 \% \\
100 \% \\
80 \% \\
\end{array}$ & $\begin{array}{l}1 / 1-2 / 28 \\
3 / 1-10 / 31 \\
11 / 1-12 / 3\end{array}$ & $\begin{array}{l}80 \% \\
100 \% \\
80 \% \\
\end{array}$ \\
\hline
\end{tabular}


The uncertainty of the annual performance metrics based on simulations, such as the site energy saving and site energy use intensity for a typical weather year, are difficult to estimate with direct calculations. The processes used in the whole-building analysis attempt to reduce uncertainty related to building simulations. To reduce the uncertainty of the annual simulation metrics, NREL calibrated the models with measured end uses and site weather. As discussed previously in the calibration procedure, NREL considers a building simulation to be calibrated when the simulated monthly energy use is within $\pm 12 \%$ of the measured monthly energy use. This $\pm 12 \%$ criterion can be assumed to represent a base level of uncertainty in annual performance metrics based on simulation results.

Input perturbation methods can also be used to model the uncertainty in whole-building energy simulations, but these methods require an extensive level of effort to prepare hundreds of input files and process results. Such efforts have produced error estimates of about $\pm 14 \%$ (Griffith 2004). Based on these two methods, NREL estimates the uncertainty of the annual performance based on simulation to be $\pm 12 \%$. Note that uncertainties in the simulated performance are much lower for percent saving metrics, which result from a comparison of one simulation to another (e.g., base-case to as-built models). Because difficult-to-know inputs are held the same in both simulations, such comparisons remove much of the uncertainty inherent in an hourly building energy simulation. Model inputs that change throughout the year, such as inconsistent occupancy, set-point changes, and equipment performance degradation, are difficult to account for in an annual building energy simulation. By comparing a base-case model to an as-built model with the same schedules, the uncertainty caused by these inconsistent model inputs is reduced.

\subsection{Whole-Building Performance Results}

The primary energy performance metric for the TTF was the site energy cost saving. The primary metric was energy cost, as it was the basis for the original energy goal of the project. To be consistent with other case studies, source and site energy consumption are also reported. NREL based the results of the TTF evaluation on these metrics with the base-case and as-built models. The results are presented in the following sections.

\subsubsection{Energy Cost Saving}

The design goal for the TTF was to reduce the HVAC $+\mathrm{L}$ by $70 \%$. To determine the success of meeting this goal, NREL first considered the HVAC $+\mathrm{L}$ energy cost saving modeling result. The models used were the calibrated base-case and the as-built models. Section 5.3 discussed formulating and calibrating the models.

Results for energy costs of both models are given in Table 5-6 and Figure 5-7. The calibrated simulation performs $63 \%$ better than an equivalent minimally code-compliant building in terms of providing the building occupants with thermal comfort, fresh air, and light. The percentage translates to an annual energy cost saving of $\$ 3,673$. NREL calculated the whole-building energy costs using an electricity cost of $\$ 0.0248 / \mathrm{kWh}$, with an on-peak demand charge of $\$ 6.15 / \mathrm{kW}$ and an off-peak demand charge of $\$ 3.75 / \mathrm{kW}$. The cost for natural gas costs was $\$ 0.385 /$ therm. Breakout electricity costs were computed based on the virtual rate of the electricity for the entire building. These costs were $\$ 0.0645 / \mathrm{kWh}$ for electricity and $\$ 0.385 /$ therm for gas. NREL modeled these energy rates based on the actual utility rates when the TTF was first occupied in 1996. The energy cost saving was calculated without plug and process loads to allow for a direct comparison to the energy cost saving design goal of the TTF. These loads are determined by occupant use of the equipment located inside the building (e.g., laboratory equipment, computers, and appliances) and will occur regardless of how efficiently the building is designed and operated. These loads are the same in both the base-case and as-built models. 
Using the plug loads in the calculation for the energy saving yields an annual cost saving of 51\% when compared to the calibrated base-case model. The typical plug loads contributed $\$ 1,388$ to the total energy costs in the as-built and calibrated base-case models. The simulated whole-building energy cost intensity, considering the HVAC $+\mathrm{L}$ and plug loads, was $\$ 0.36 / \mathrm{ft}^{2}\left(\$ 3.88 / \mathrm{m}^{2}\right)$ for the as-built model and $\$ 0.73 / \mathrm{ft}^{2}$ $\left(\$ 7.86 / \mathrm{m}^{2}\right)$ for the calibrated base case.

Table 5-6 Annual Energy Cost Results from Calibrated Models Using TMY2 Weather Data

\begin{tabular}{|l|c|c|c|c|}
\hline \multicolumn{1}{|c|}{ End Use } & $\begin{array}{c}\text { Calibrated Base- } \\
\text { Case Model }\end{array}$ & As-Built Model & Savings & $\begin{array}{r}\text { Percent } \\
\text { Savings }\end{array}$ \\
\hline \hline Task and Area Lighting & $\$ 4,116$ & $\$ 1,051$ & $\$ 3,066$ & $74 \%$ \\
\hline Heating & $\$ 409$ & $\$ 440$ & $-\$ 31$ & $-8 \%$ \\
\hline Cooling & $\$ 621$ & $\$ 141$ & $\$ 480$ & $77 \%$ \\
\hline Pumps & $\$ 149$ & $\$ 27$ & $\$ 122$ & $82 \%$ \\
\hline Fans & $\$ 521$ & $\$ 404$ & $\$ 117$ & $23 \%$ \\
\hline Hot Water & $\$ 82$ & $\$ 46$ & $\$ 36$ & $44 \%$ \\
\hline Exterior Lighting & $\$ 71$ & $\$ 71$ & $\$ 0$ & $0 \%$ \\
\hline \hline Total HVAC+L & $\$ 5,969$ & $\$ 2,179$ & $\$ 3,790$ & $\mathbf{6 3 \%}$ \\
\hline Plug Loads & $\$ 1,389$ & $\$ 1,389$ & $\$ 0$ & $0 \%$ \\
\hline \hline Total Building & $\$ 7,358$ & $\$ 3,568$ & $\$ 3,790$ & $\mathbf{5 2 \%}$ \\
\hline
\end{tabular}



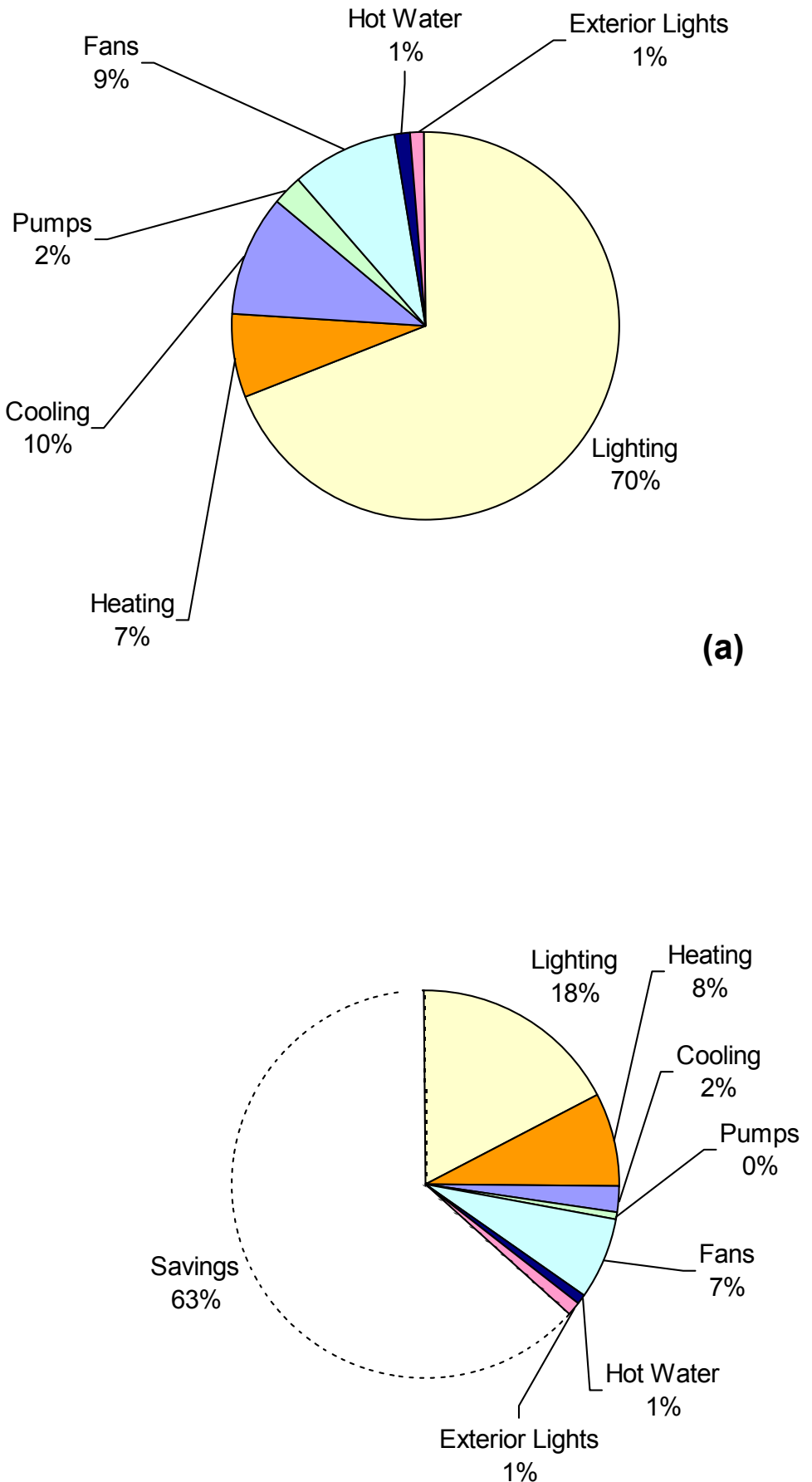

(b)

Figure 5-7 Pie charts of annual energy costs (excluding plug loads) from (a) the calibrated base-case model and (b) the calibrated as-built model 


\subsubsection{Lighting Energy Costs}

The lighting system produced the largest energy cost saving. As discussed in Section 4.4, the lighting system is a combination of daylighting strategies, efficient lamps and fixtures, and occupancy sensor controls. The design levels of lighting have worked well based on the installed densities and the daylighting. Lighting energy was reduced by $74 \%$ based on the analysis, with an annual energy cost saving of $\$ 3,066$. The saving is a combination of reduced LPD, including using wall-packs for emergency lighting, motion sensors, and daylighting. This order was used to determine savings for each technology.

Security lighting activated by motion sensors eliminated the need for 24-hour security lighting. An annual saving of $2,630 \mathrm{kWh} / \mathrm{yr}$, or $\$ 170$, is realized by not operating $10 \%$ of the electric lights 24 hours per day.

Figure 5-8 shows the monthly cost comparisons for operating the electric lighting system. The actual savings with respect to the base-case building are shown. Lighting savings due to lower LPD as well as daylighting/occupancy controls are shown separately. The lighting saving due to a lower installed LPD was $56 \%$ of the total lighting saving, with daylighting and occupancy sensors responsible for the remaining $44 \%$. Some of the saving due to lower LPD can be attributed to daylighting providing a portion of the interior lighting requirements, even with the lights on. The slightly lower illuminance levels at night due to a lower LPD did not cause occupant complaints. NREL calculated the lower LPD saving by simulating the base-case model with the code- compliant LPD and the installed LPD. The energy cost difference between the code-compliant LPD base-case model and the installed LPD base-case model represents the savings due to a lower LPD.

As expected, the Figure 5-8 shows that the savings from daylighting are greater during the summer months when days are longer. Note that variations in the energy consumed by day in the base case are caused by the number of holidays and weekend days, which varies by month; the same weekday schedules were used for both the base-case and the as-built models. Also, note that occupancy sensors are inherent in the schedules and savings from motion sensors alone cannot be discerned from simulation. Figure 5-9 shows the impact of the daylighting controls between a clear and a cloudy day. The top curve represents the power draw from operating without daylighting controls; the lower curve is measured lighting power. The difference between these curves represents savings. On a clear day, the lights are generally off. On a cloudy day, the lights are on much more often, but daylighting still contributes to the saving. 


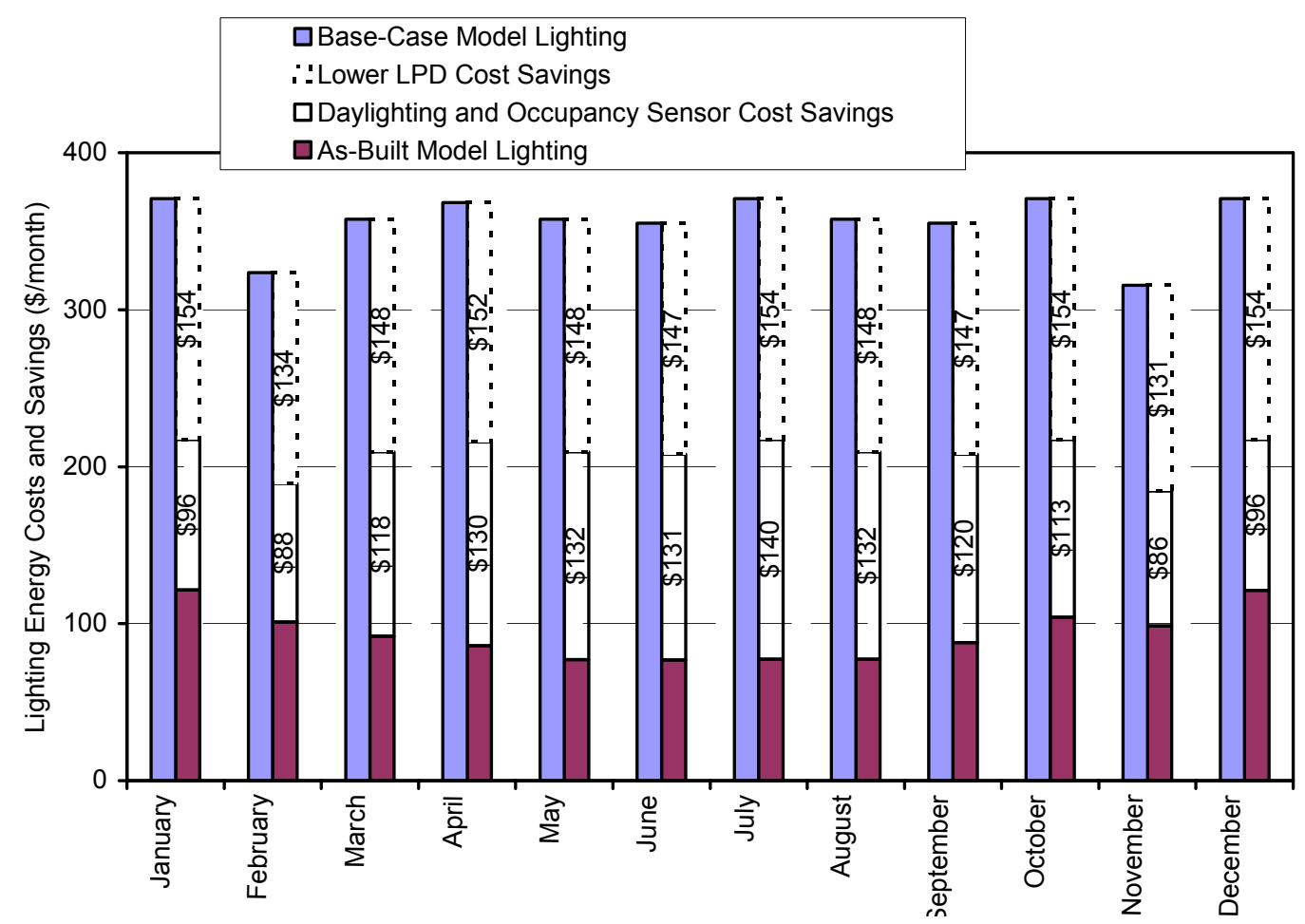

Figure 5-8 Graph of energy costs and savings for lighting by month based on a typical operating year

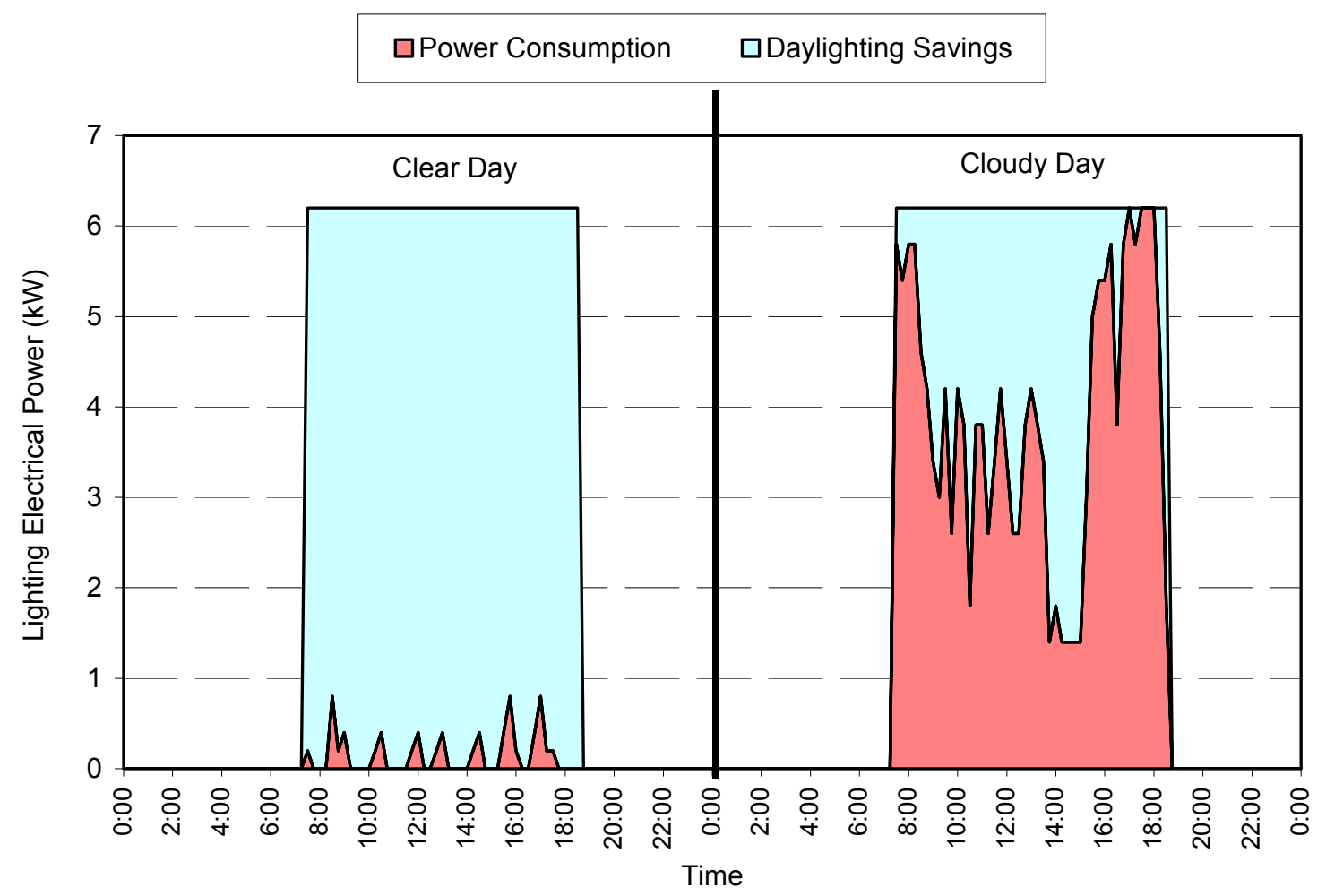

Figure 5-9 Electric lighting power consumption on typical clear day and cloudy day 
In this building, daylighting controls use a single-step control system; the lights are either on or off. Dead-band set points and operating periods were set to prevent excessive cycling during periods of partial cloud cover. The single-step control system could be improved with continuously dimming fixtures and controls. Based on simulation, continuous dimming controls would further reduce lighting energy use by $6.5 \%$. It is anticipated that this control would be more acceptable to the building occupants. A dimming control system was not originally implemented because this technology was not readily available at a reasonable cost at the time the building was designed.

\subsubsection{HVAC Energy Costs}

In most commercial buildings, internal gains that result from operating electric lights help to heat the building. Reducing the internal gains from the lighting system should increase the building's heating loads and decrease the building's cooling load. Because of the daylighting, the electric lights do not introduce as much heat to the building. As a result, the heating loads are slightly higher in the TTF than the base-case building.

When the TTF requires heating, it typically occurs only during the early morning hours to warm up from nightly temperature setback. Although the temperature set point is set back to $55^{\circ} \mathrm{F}\left(13^{\circ} \mathrm{C}\right)$ every night, the temperature in the TTF rarely drifts that low.

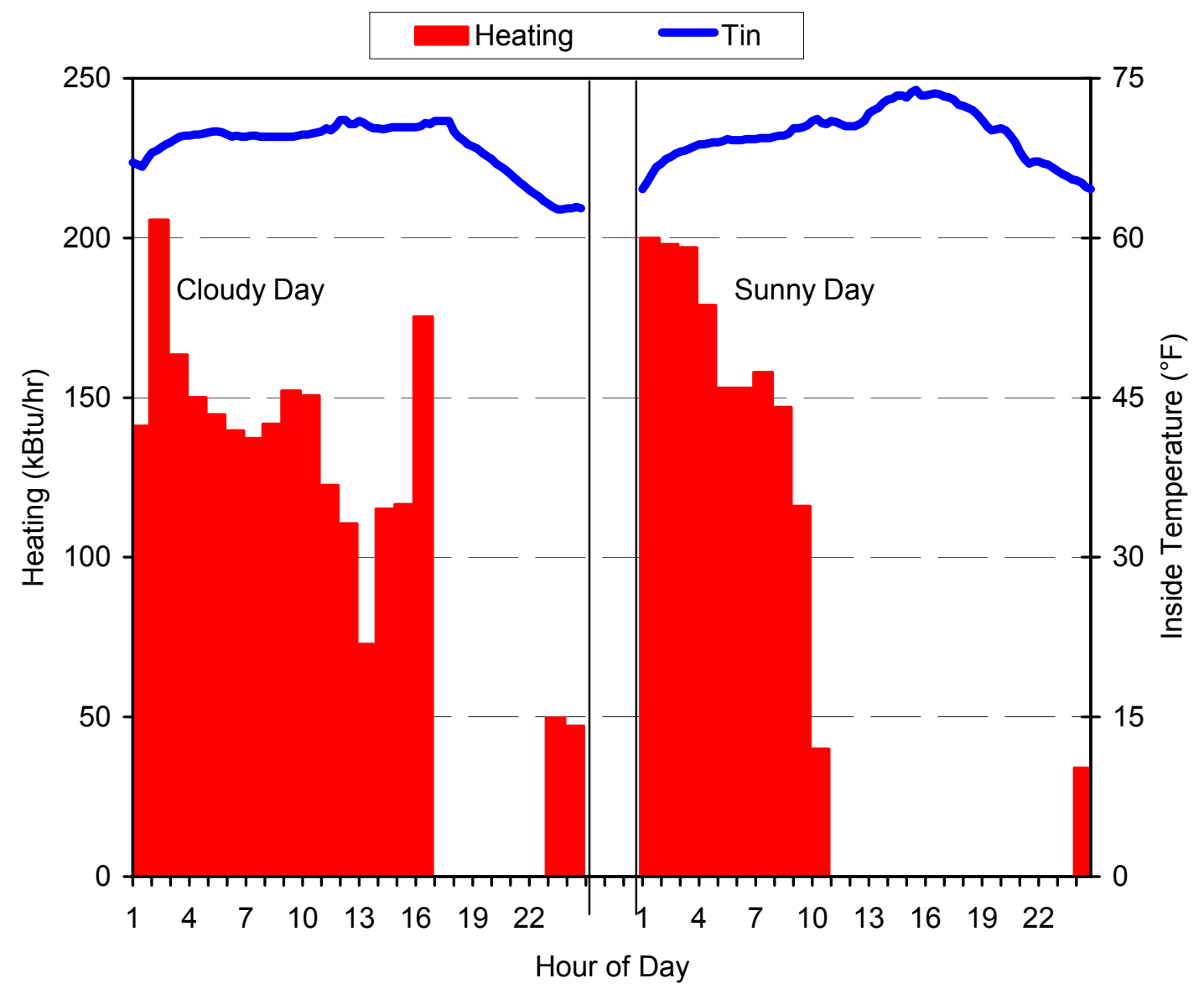

Figure 5-10 Heating loads on a cloudy day compared with heating loads on a sunny day 
Heating loads on a cloudy day and a sunny winter day were examined with the data presented in Figure 5-10. This figure shows measured heating rates during a cloudy day and a typical sunny winter day. For both of these days, the typical operation schedule was changed. The set point was $64^{\circ} \mathrm{F}\left(19^{\circ} \mathrm{C}\right)$ from 5 p.m. to 12 a.m. with the remainder of the day was set to $70^{\circ} \mathrm{F}\left(21^{\circ} \mathrm{C}\right)$. After the morning warmup, passive solar heating and internal gains met most of the building's heating requirements.

Heating loads are affected by the overall thermal performance of the building envelope. Although high levels of thermal insulation are important, two- and three-dimensional heat flows through construction details can have an important impact; these heat flows are referred to as thermal bridges. Although designers took care to detail plans for the TTF that would minimize thermal bridging, three problem areas were identified during construction that add to the thermal loads of the building.

1. A thermal bridge exists in the window frames. Figure 5-11 shows a sample of infrared images used to determine that the window and doorframes installed were not thermally broken as had been specified. Compared to the base-case model, it is estimated that as much as $13.6 \mathrm{MMBtu} / \mathrm{yr}(14,350$ $\mathrm{MJ} / \mathrm{yr}$ ) are lost through window frames because the aluminum frames are not thermally broken.

2. A thermal bridge exists where a retaining wall meets the building: Although the impact of this thermal bridge on the annual heating and cooling performance is minimal, multiple incidences of thermal bridging can offset savings from the low-energy envelope. This flaw was built according to plan and should have been identified during the design phase.

3. During construction, it was decided to relocate the foundation insulation for structural reasons. (See Section 3.4.1.) As a result, 6 in. $(15 \mathrm{~cm})$ of insulation was removed, creating a thermal bridge. The thermal bridge is approximately $390-\mathrm{ft}(119-\mathrm{m})$ long by 6 -in. $(15-\mathrm{cm})$ wide. NREL estimates that an additional 4.3 MMBtu/yr (1,260 kWh/yr) are lost through this thermal bridge. Figure 5-12 shows infrared thermal images that indicate heat loss through the foundation.
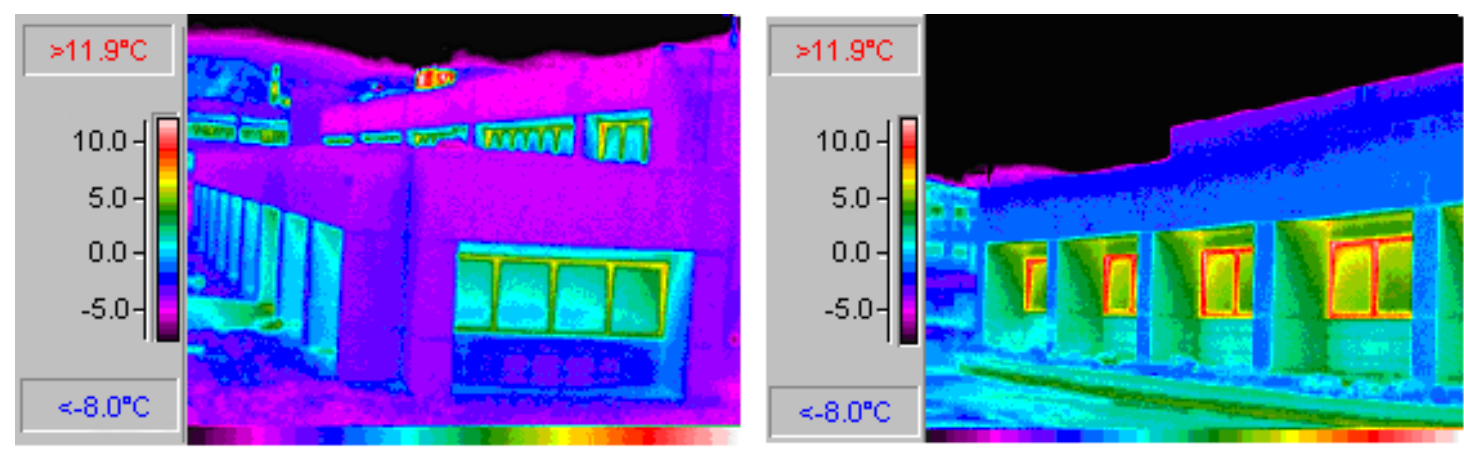

Figure 5-11 Infrared thermal images showing heat loss through window frames
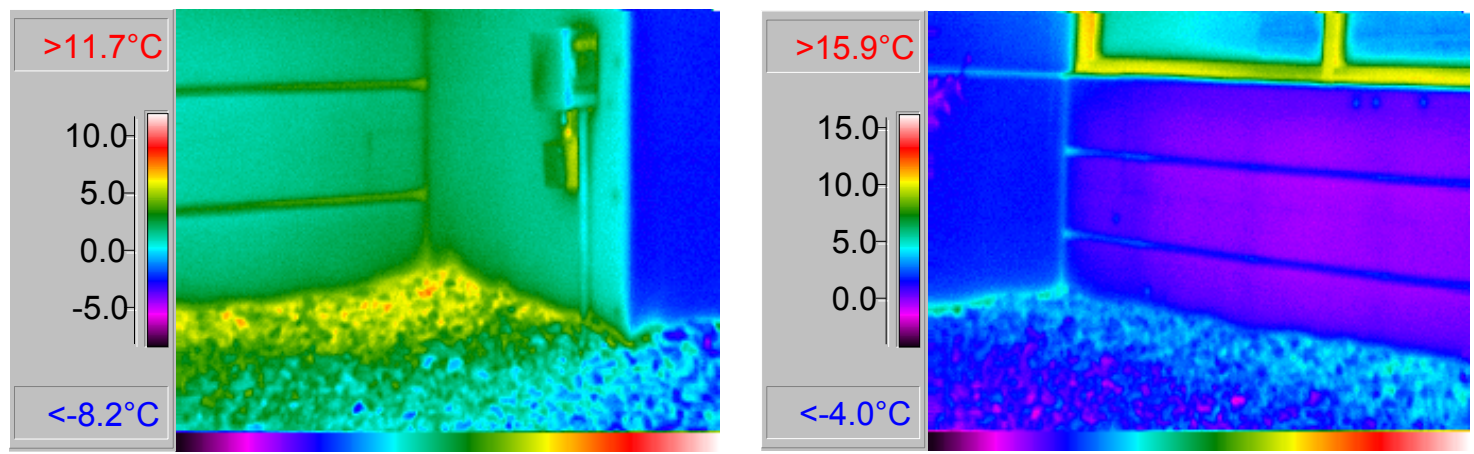

Figure 5-12 Infrared thermal images showing heat loss at the foundation 
Ground heat transfer is another area where complex three-dimensional heat flows are present. There are many questions surrounding modeling heat transfer through slab-on-grade floors. The common practice of insulating only the perimeter of the slab is justified only if the ground under the center portion of the slab will eventually reach an equilibrium temperature under the influence of the controlled environment above the slab. Through STEM tests and thermography, NREL found that more heat loss is occurring through the floor and window frames than was predicted by the models. Based on other work (Deru 2002), researchers suspect that the ground under the center of the slab is not reaching equilibrium. Additional work would be required to determine the impacts of insulating the entire slab. One impact of both of these heat transfer losses is comfort. Based on a cold floor and thermal comfort models, the temperature of feet is critical for comfort. Warmer floors from insulation may result in lower overall building temperatures because people with warmer feet may be more comfortable at lower zone temperatures.

The cooling load energy cost was reduced by $77 \%$ compared to the base-case model, saving $\$ 480$ in cooling energy costs. The main contributors to the saving were daylighting, which reduced the internal gains from operating electric lights, and overhangs on south-facing windows, which block direct solar gains during the cooling season. Additional saving was achieved by using a two-stage evaporative cooler with variable-speed supply and return fans. The cooling system saving due to the evaporative cooling system and to reducing internal gains was determined by simulating the as-built model with the base-case VAV system. The difference in ventilation and air-conditioning (VAC) costs between the as-built model with the VAV and the as-built model with the evaporative cooling system represent the saving due to the evaporative cooling system. Both the evaporative and VAV cooling systems were modeled with a VSD supply fan. The evaporative cooling system was responsible for $\$ 219$ of the $\$ 480$ cooling system saving. The VAV system used less fan energy than the evaporative system. However, the overall VAC saving due to the evaporative cooling system was $\$ 217$, as shown in Table 5-7. The total VAC saving was $\$ 719$, of which $70 \%$ was due to reduced internal gains.

Table 5-7 Results for Annual VAC Energy Costs

\begin{tabular}{|l|c|c|c|c|c|c|}
\hline End use & $\begin{array}{c}\text { Calibrated } \\
\text { Base-Case } \\
\text { Model }\end{array}$ & $\begin{array}{c}\text { As-Built } \\
\text { Model }\end{array}$ & $\begin{array}{c}\text { Total } \\
\text { Savings }\end{array}$ & $\begin{array}{c}\text { As-Built } \\
\text { Model with } \\
\text { VAV }\end{array}$ & $\begin{array}{c}\text { Evaporative } \\
\text { Cooling } \\
\text { System } \\
\text { Savings }\end{array}$ & $\begin{array}{c}\text { Reduced } \\
\text { Internal } \\
\text { Gains } \\
\text { Savings }\end{array}$ \\
\hline Cooling & $\$ 621$ & $\$ 141$ & $\$ 480$ & $\$ 360$ & $\$ 219$ & $\$ 261$ \\
\hline Pumps & $\$ 149$ & $\$ 27$ & $\$ 122$ & $\$ 138$ & $\$ 111$ & $\$ 11$ \\
\hline Fans & $\$ 521$ & $\$ 404$ & $\$ 117$ & $\$ 290$ & $-\$ 113$ & $\$ 231$ \\
\hline Total VAC & $\$ 1,291$ & $\$ 572$ & $\$ 719$ & $\$ 788$ & $\$ 217$ & $\$ 503$ \\
\hline
\end{tabular}

The evaporative cooler provided an additional benefit as well. Although not part of the analysis, the actual building experienced highly variable loads that were never predicted during the design of the building. Because the evaporative cooler is a one-pass system, the variable loads were easily flushed from the building. If a traditional system had been used, the equipment could not have met the loads.

Using a two-stage evaporative cooling system instead of a conventional chilled-water or DX system reduced the energy used to meet remaining cooling loads (beyond the conference room air-conditioning unit) because it employs no compressor. The evaporative cooler's performance was analyzed for the period from June 6 to June 17, 1998. Direct evaporative coolers are constant enthalpy processes. The indirect portion does provide sensible cooling. As a result, a traditional coefficient of performance (COP) calculation comparing the enthalpy change with the power input is not appropriate for evaporative cooling systems. Creating an effective heat transfer based on the temperature difference across the cooler can provide a means for comparison of systems. The "cooling energy" was modeled by assuming it is 
proportional to the temperature difference. This term, $\Delta \dot{Q}$, can be computed using the following equation:

$$
\Delta \dot{Q}=\dot{m} c_{p}\left(T_{d b, \text { entering }}-T_{d b, \text { leaving }}\right)
$$

where

$$
\begin{array}{ll}
\dot{m} & \text { is the mass flow of conditioning air through the air handler, } \\
c_{p} & \text { is the specific heat of air at constant pressure, } \\
T_{d b, \text { entering }} & \text { is the dry-bulb temperature of air entering the cooler, and } \\
T_{d b, \text { leaving }} & \text { is the dry-bulb temperature of air leaving the cooler. }
\end{array}
$$

To achieve this cooling, electrical energy is consumed by the main supply and scavenger fans and the pumps used to wet the evaporative medium. NREL calculated the COPs for 5-minute intervals by dividing $\Delta \dot{Q}$ by the electricity consumed by fans and pumps over that time. This method provides an indication of the amount of energy required to deliver cooling. The results of this analysis of measured data for the evaporative cooling unit showed values that averaged 9.0 when just the direct section was running, and 7.4 when both the direct and indirect sections where running. The range of COP values varied from 5.6 to 15.2 for the direct-only section and 6.2 to 8.7 when both sections were running. It should be noted that both sections are required to get the temperature drop needed for cooling the building, even though the efficiency of the system decreases when the indirect section is operating, in part because of the energy to operate the scavenger fan.

Variable speed fans were specified for the HEXs. As discussed in Section 4.5, these fans used a thirdparty controller that increased the fan energy at part-loads. They are now controlled as on/off. The VSDs for the ceiling fans were never programmed to operate. In addition, NREL set the direction of the ceiling fans to the downward (clockwise) direction. The impact of these features was not evaluated in terms of performance in the building. The ceiling fans are controlled on a temperature difference from the ceiling to the floor so they do not operate continuously. The energy for all these fans was included in the previous fan energy discussion.

Figure 5-13 shows costs for operating both the base case and the TTF HVAC systems. Trends shown in this figure and from previous HVAC energy cost discussions indicate that the TTF has the following characteristics:

- lower cooling costs because of high evaporative cooler efficiency and reduction of internal and solar gains,

- lower pumping costs because of the elimination of chilled water pumps and limited run-times for the hot-water pumps,

- higher annual heating costs because reduced electric lights add less heat to the building,

- passive solar heating during winter months, and

- overall fan energy costs were reduced due to reduced internal gains. The evaporative cooling system used more fan energy as compared to a VAV system due to increased supply airflow. 


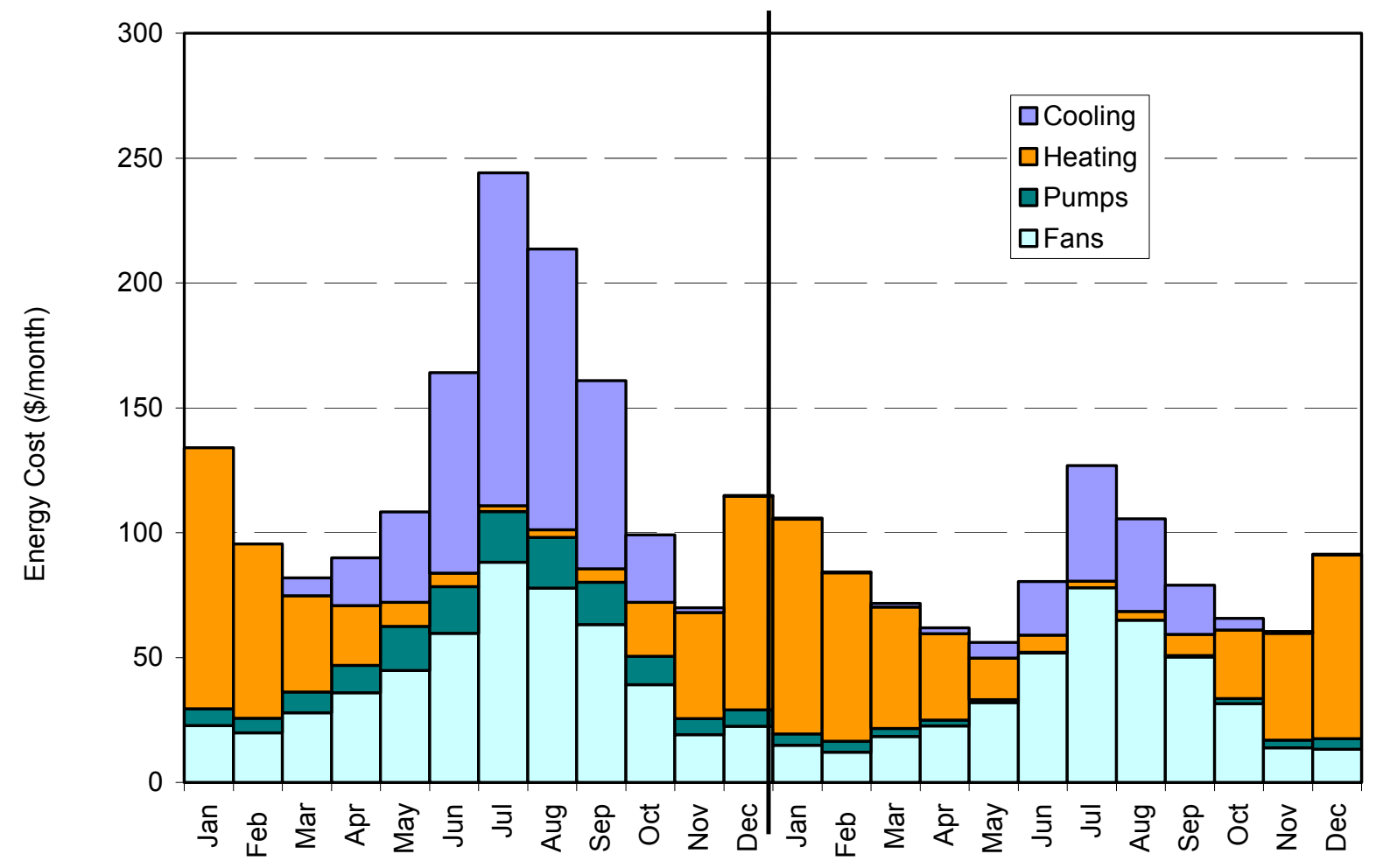

Figure 5-13 Comparison of HVAC operating costs

Figure 5-14 shows the total daily building energy consumption versus daily average outdoor dry-bulb temperature for the base-case and the as-built models. This figure shows that the low-energy building requires less energy to operate at all ambient temperatures. The low point in each curve indicates the balance point - that is, the point where the building needs minimal heating and cooling. In this case, the balance point for the TTF is $64^{\circ} \mathrm{F}\left(18^{\circ} \mathrm{C}\right)$, whereas the base case is $57^{\circ} \mathrm{F}\left(14^{\circ} \mathrm{C}\right)$. The higher temperature for the as-built building indicates that the lighting is not providing heat to the building. In addition, the flatter TTF curve indicates a broad range of temperatures at which the building needs minimal heating or cooling. This also shows that it can effectively float at these temperatures for a reasonable period. Both buildings are heating climate driven and closely coupled to ambient temperature, indicating that both buildings are skin-dominated and not load-dominated. Based on energy costs, a different trend is evident in that peak summer demands dominate the base-case cooling costs, as shown in Figure 5-13. In the asbuilt model, however, the HVAC energy costs are similar during heating and cooling seasons. 


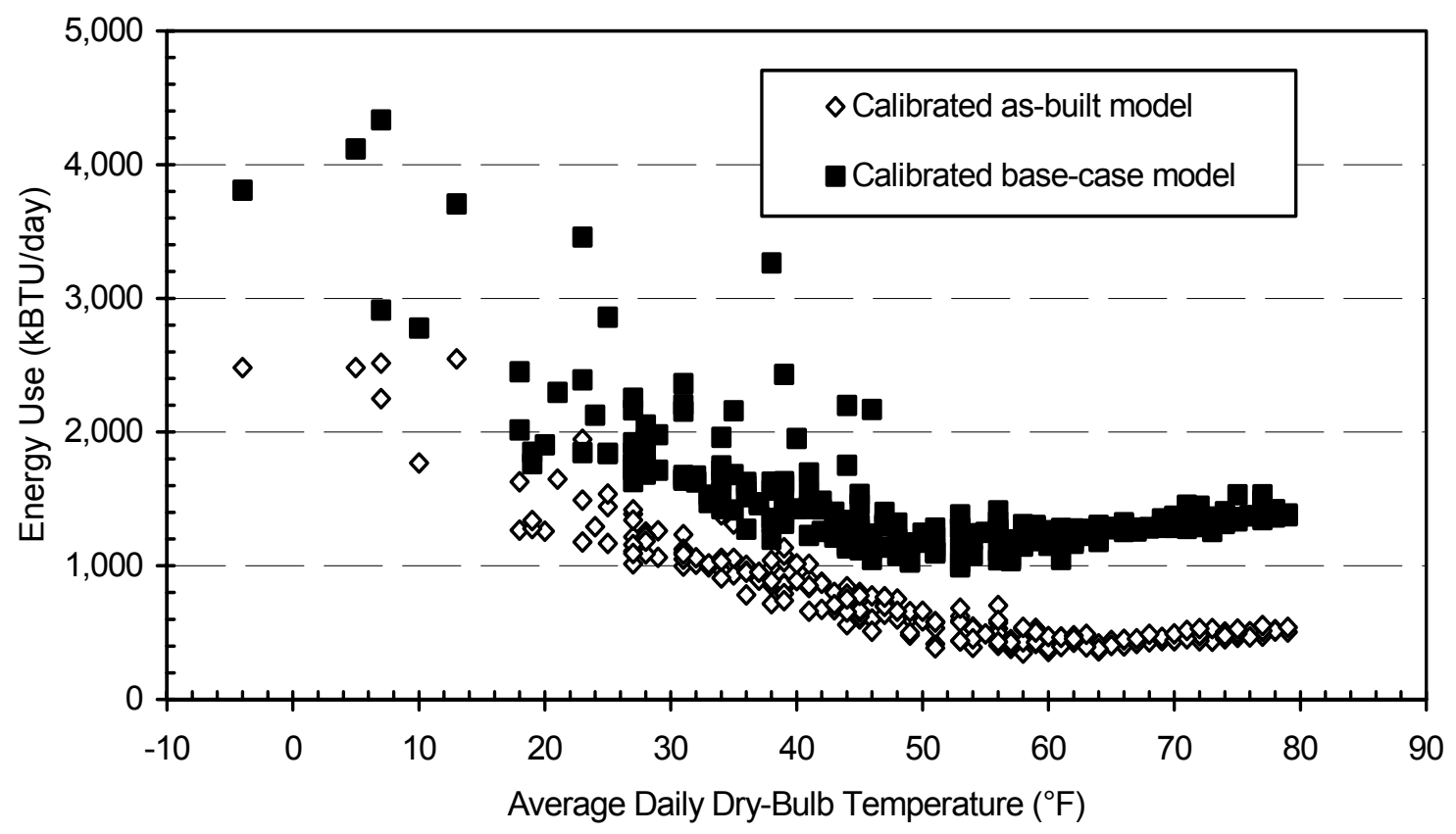

Figure 5-14 Daily energy use for heating, cooling, pumps, and fans for the TTF compared with the base-case building

\subsubsection{Demand Analysis}

Further investigation of the energy cost savings of the as-built model reveals that the demand saving is $58 \%$ of the total energy cost savings. Of the total $\$ 3,970$ in energy cost savings, $\$ 2,305$ is from the reduction in on and off peak demand charges. Utility costs by utility charge type are shown in Table 5-8. Monthly on-peak demand savings are shown in Figure 5-15.

Table 5-8 Annual Energy Costs by Type from Calibrated Models Using TMY2 Weather Data

\begin{tabular}{|l|c|c|c|c|}
\hline \multicolumn{1}{|c|}{ Utility Cost } & $\begin{array}{c}\text { Calibrated Base- } \\
\text { Case Model }\end{array}$ & As-Built Model & Savings & $\begin{array}{c}\text { Percent } \\
\text { Savings }\end{array}$ \\
\hline Gas & $\$ 491$ & $\$ 486$ & $\$ 5$ & $1 \%$ \\
\hline Electrical Energy & $\$ 2,640$ & $\$ 1,160$ & $\$ 1,480$ & $56 \%$ \\
\hline On-peak Demand & $\$ 2,930$ & $\$ 1,307$ & $\$ 1,623$ & $55 \%$ \\
\hline Off-peak Demand & $\$ 1,297$ & $\$ 615$ & $\$ 682$ & $53 \%$ \\
\hline \hline Total Building & $\$ \mathbf{7 , 3 5 8}$ & $\$ \mathbf{3 , 5 6 8}$ & $\$ \mathbf{3 , 9 7 0}$ & $\mathbf{5 2 \%}$ \\
\hline
\end{tabular}




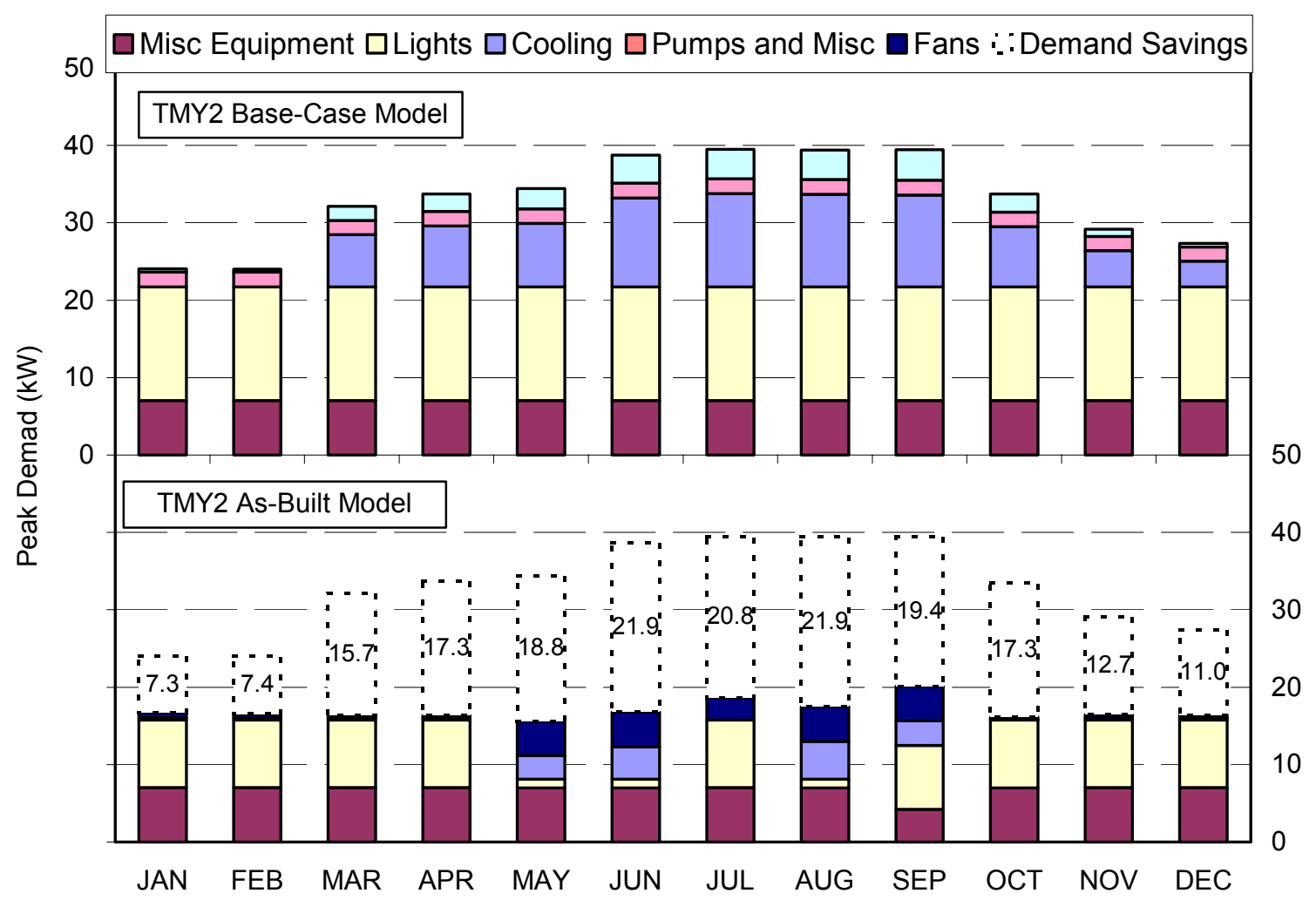

Figure 5-15 On-peak demand of as-built and base-case models

Based on typical office equipment loads, the peak annual demand for the as-built model was $20.1 \mathrm{~kW}$ in September and the lowest monthly peak was in May at $15.6 \mathrm{~kW}$. Compared to the base-case, peak demands reductions ranged from $7.3 \mathrm{~kW}$ to $21.9 \mathrm{~kW}$, resulting in the largest single source of energy cost savings. Daylighting, reduced cooling loads, and the evaporative cooling system were responsible for the largest summer demand savings. The July peak demand occurred at 9 a.m., when daylighting did not reduce the lighting load. The May, June, and August peak demands occurred in the early afternoon during peak cooling periods. The magnitude of the May, June, and August peaks was similar to other months due to daylighting reducing the lighting loads. The base-case model peaked in the afternoon during the cooling months of July and August. Not only did daylighting and evaporative cooling reduce the demand, the annual peak demand was shifted from July to September. The September peak demand occurred at 6 p.m., when the lights were on coincident with a cooling load. All the other peaks occurred at 9 a.m., when the building is occupied, and daylighting does not have a significant impact on the lighting load.

A primary assumption in simulating peak demands is that irregular building use, which can often result in a monthly peak demand, is not included in the models. Additionally, peak demands in the as-built and base-case models are predicted with DOE-2 on hourly peaks, and not the 15 -minute peaks used to calculate the NREL utility demand charges. It should also be noted that no attempt was made to use demand management strategies to further reduce peak loads. These techniques may be able to further reduce the demand and associated costs.

\subsubsection{Site Energy Savings}

Summary whole-building site energy use results are shown in Figure 5-16 and Table 5-9. The base-case model site energy use intensity was $49.1 \mathrm{kBtu} / \mathrm{ft}^{2}\left(558 \mathrm{MJ} / \mathrm{m}^{2}\right)$ with the as-built model energy use 
intensity at $28.9 \mathrm{kBtu} / \mathrm{ft}^{2}\left(328 \mathrm{MJ} / \mathrm{m}^{2}\right)$. These numbers result in a site energy use saving of $41 \%$, which is less than the energy cost saving of 52\% due to the differences in gas and electricity cost per unit of site energy.

Table 5-9 Results for Annual Energy Use from Calibrated Models Using TMY2 Weather Data

\begin{tabular}{|l|c|r|r|r|}
\hline \multicolumn{1}{|c|}{ End use } & $\begin{array}{c}\text { Calibrated Base- } \\
\text { Case Model } \\
\mathbf{( k W h )}\end{array}$ & $\begin{array}{c}\text { As-Built } \\
\text { Model (kWh) }\end{array}$ & $\begin{array}{c}\text { Savings } \\
\mathbf{( k W h )}\end{array}$ & $\begin{array}{c}\text { Percent } \\
\text { Savings }\end{array}$ \\
\hline \hline Task and Area Lighting & 63,815 & 16,287 & 47,528 & $74 \%$ \\
\hline Heating (gas) & 31,126 & 33,489 & $-2,363$ & $-8 \%$ \\
\hline Cooling & 9,628 & 2,193 & 7,435 & $77 \%$ \\
\hline Pumps & 2,310 & 411 & 1,907 & $82 \%$ \\
\hline Fans & 8,081 & 6,260 & 1,821 & $23 \%$ \\
\hline Hot Water (gas) & 6,241 & 3,486 & 2,755 & $44 \%$ \\
\hline Exterior Lighting & 1,101 & 1,101 & 0 & $0 \%$ \\
\hline \hline Total HVAC+L & $\mathbf{1 2 2 , 3 0 2}$ & $\mathbf{6 3 , 2 2 7}$ & $\mathbf{5 9 , 0 7 5}$ & $\mathbf{4 8 \%}$ \\
\hline Plug Loads & $\mathbf{2 1 , 5 3 2}$ & 21,532 & & $0 \%$ \\
\hline \hline Total Building & $\mathbf{1 4 3 , 8 3 4}$ & $\mathbf{8 4 , 7 5 9}$ & $\mathbf{5 9 , 0 7 5}$ & $\mathbf{4 1 \%}$ \\
\hline
\end{tabular}

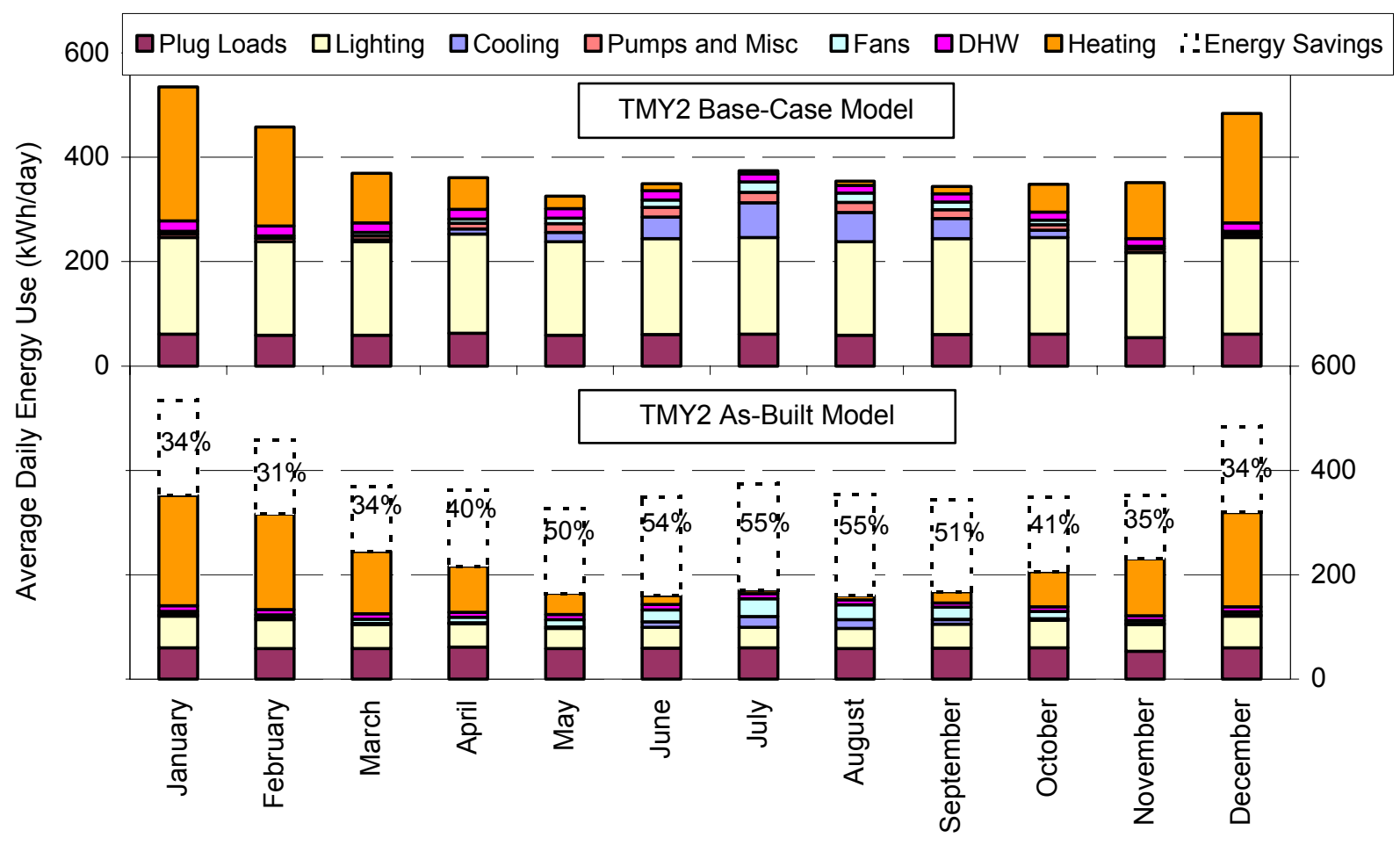

Figure 5-16 Average daily energy use from the calibrated base-case model and the calibrated as-built model 


\subsubsection{Source Energy Savings}

As discussed previously, source or primary energy is the sum of the energy directly consumed at the site and the energy consumed by producing and delivering energy products. Documenting primary energy consumption is useful when emissions from energy sources are a concern.

The TMY2 base-case building consumed $383,622 \mathrm{kWh}$ of source energy when simulated with TMY2 weather data. The annual base-case source energy consumption intensity was $130.9 \mathrm{kBtu} / \mathrm{ft}^{2} \cdot \mathrm{yr}$ $\left(1,487 \mathrm{MJ} / \mathrm{m}^{2} \cdot \mathrm{yr}\right)$. NREL calculated the base-case source energy based on $31 \%$ electricity conversion and delivery efficiency from source to site and $93 \%$ natural gas source efficiency. The electrical source-tosite efficiency was based on the conversion and distribution efficiency averaged over all sources of electricity generation in the nation, as reported by EIA (2000).

The simulated site energy consumption for a typical weather year was $47,784 \mathrm{kWh}$ of electricity and $37,367 \mathrm{kWh}$ of natural gas. The site use was based on the simulated consumption for a TMY2 weather year with the as-built model. At $31 \%$ source-to-site electricity conversion efficiency, NREL calculated a typical source energy consumption of $66.2 \mathrm{kBtu} / \mathrm{ft}^{2} \cdot \mathrm{yr}\left(752 \mathrm{MJ} / \mathrm{m}^{2} \cdot \mathrm{yr}\right)$. Additionally, the TTF realized a simulated source energy use saving of $49 \%$ compared to the TMY 2 base-case source energy consumption.

NREL also calculated emission reductions based on source energy consumption for typical weather years for the as-built and the base-case models. NREL calculated the electricity emissions based on the data given in Table 5-10 and a 10\% transmission and distribution loss from the generation location to the site. Table 5-10 summarizes emissions for electricity generated in the United States (EnergyPlus 2004).

Table 5-11 summarizes emissions for natural gas consumption (EnergyPlus 2004).

Table 5-10 U.S. Electricity Generation Emissions

\begin{tabular}{|l|c|}
\hline \multicolumn{1}{|c|}{ Emissions } & $\begin{array}{c}\text { Emissions Amount per Unit } \\
\text { of Electricity Generated } \\
\text { lbs/MWh (g/MJ) }\end{array}$ \\
\hline $\mathrm{CO}_{2}$ (carbon dioxide) & $1,335.7(168.3)$ \\
\hline $\mathrm{SO}_{2}$ (sulfur dioxide) & $6.9(0.87)$ \\
\hline $\mathrm{NO}_{\mathbf{X}}$ (oxides of nitrogen) & $3.3(0.41)$ \\
\hline $\mathrm{CO}$ (carbon monoxide) & $0.33(0.042)$ \\
\hline $\mathrm{CH}_{4}$ (methane) & $0.008(0.001)$ \\
\hline $\mathrm{PM}$ (particulate matter) & $0.23(0.029)$ \\
\hline
\end{tabular}

Table 5-11 Natural Gas Emission Factors

\begin{tabular}{|l|r|}
\hline \multicolumn{1}{|c|}{ Emissions } & $\begin{array}{c}\text { Emissions Amount per Unit } \\
\text { of Natural Gas Used } \\
\text { lbs/MWh }(\mathrm{g} / \mathrm{MJ})\end{array}$ \\
\hline $\mathrm{CO}_{2}$ & $398.0(50.2)$ \\
\hline $\mathrm{SO}_{2}$ & $2.0 \mathrm{E}-03(2.51 \mathrm{E}-04)$ \\
\hline $\mathrm{NO}_{\mathrm{X}}$ & $0.33(4.19 \mathrm{E}-02)$ \\
\hline $\mathrm{CO}$ & $0.28(3.52 \mathrm{E}-02)$ \\
\hline $\mathrm{CH}$ & $7.63 \mathrm{E}-03(9.63 \mathrm{E}-04)$ \\
\hline $\mathrm{PM}$ & $2.52 \mathrm{E}-02(3.18 \mathrm{E}-03)$ \\
\hline
\end{tabular}


NREL estimates annual emissions saved to be $86,377.1 \mathrm{lb}(39,180.0 \mathrm{~kg})$ of $\mathrm{CO}_{2}, 445.4 \mathrm{lb}(202.0 \mathrm{~kg})$ of $\mathrm{SO}_{2,} 213.1 \mathrm{lb}(96.7 \mathrm{~kg})$ of $\mathrm{NO}_{\mathrm{X}}, 21.4 \mathrm{lb}(9.7 \mathrm{~kg})$ of $\mathrm{CO}, 0.5 \mathrm{lb}(0.2 \mathrm{~kg})$ of $\mathrm{CH}_{4}$, and $14.9 \mathrm{lb}(6.7 \mathrm{~kg})$ of $\mathrm{PM}$, when compared with emissions from the base case. These results are summarized in Table 5-12.

Table 5-12 Emissions Reduction Summary

\begin{tabular}{|l|r|r|r|}
\hline & \multicolumn{1}{|c|}{$\begin{array}{c}\text { TMY2 Base-Case } \\
\text { Emissions } \\
\mathrm{lb}(\mathrm{kg})\end{array}$} & \multicolumn{1}{|c|}{$\begin{array}{c}\text { TMY2 As-Built } \\
\text { Emissions } \\
\mathrm{lb}(\mathrm{kg})\end{array}$} & \multicolumn{1}{c|}{$\begin{array}{c}\text { Emissions } \\
\text { Reductions } \\
\mathrm{lb}(\mathrm{kg})\end{array}$} \\
\hline \hline $\mathrm{CO}_{2}$ & $171,295.5(77,698.3)$ & $84,918.3(33,518.3)$ & $86,377.1(39,180.0)$ \\
\hline $\mathrm{SO}_{2}$ & $808.2(366.6)$ & $362.8(164.5)$ & $445.4(202.0)$ \\
\hline $\mathrm{NO}_{\mathrm{x}}$ & $398.9(180.9)$ & $185.7(84.2)$ & $213.1(96.7)$ \\
\hline $\mathrm{CO}$ & $49.1(22.3)$ & $27.6(12.5)$ & $21.4(9.7)$ \\
\hline $\mathrm{CH}_{4}$ & $1.2(0.6)$ & $0.7(0.3)$ & $0.5(0.2)$ \\
\hline $\mathrm{PM}$ & $27.9(12.6)$ & $13.0(5.9)$ & $14.9(6.7)$ \\
\hline
\end{tabular}

\subsection{Occupant Survey}

A low-energy building must also produce a satisfactory internal environment for the occupants. This section presents a summary of the results of a survey of TTF occupants that was designed to evaluate occupant satisfaction with the TTF. The survey was developed to evaluate daylighting systems and occupant satisfaction and was created as part of Task 21, Subtask D for the International Energy Agency, Solar Heating and Cooling Programme (IEA/SHC) (Hygge and Löfberg 1999). Occupants were questioned about environment satisfaction, thermal comfort, lighting, ventilation and noise. Questions were asked in different ways to increase reliability of the study.

The survey was administered between May 28, 1998, and August 19, 1998. The building housed 12 occupants at the time of the survey, which resulted in a small survey sample size. Four additional surveys were sent to individuals who had recently occupied the building. The survey response rate was $81 \%$, with 13 of 16 surveys being returned. The small sample size indicates that results are not statistically significant; because the building is small, it is not possible to obtain a large data set.

Table 5-13 shows general responses characterized as either positive or negative. Negative responses were typically from the same individuals. The remainder of this section discuss outcomes summarized in this table and provides the number of respondents along with selected comments provided on responses.

Twelve of the 13 occupants responded to a question on the overall building environment. One occupant $(8 \%)$ indicated some dissatisfaction; 11 occupants $(91 \%)$ indicated that they were either very satisfied (7 occupants) or somewhat satisfied (4 occupants).

Two questions were asked on the topic of thermal comfort, but stated differently. One asked the occupant about the thermal comfort in the workspace; the other referenced temperatures in the workspace. Eleven of the 13 responses answered the question on how they rated the thermal comfort. Eight occupants (73\%) responded that the thermal comfort level in the TTF was about right; one occupant (9\%) responded that it was too hot; one occupant ( $9 \%$ ) responded that it was too cold, and one occupant $(9 \%)$ responded that there was wide variation. Twelve of the 13 responses answered the similar question referencing temperature satisfaction. Seventy-five percent of the survey responses indicated that they were satisfied with the TTF temperature, while $25 \%$ were dissatisfied. Within the $75 \%$ satisfaction response, $25 \%$ indicated that they were very satisfied, while $50 \%$ indicated that they were somewhat satisfied. Occupant responses to the questions on thermal comfort level and temperature satisfaction were consistent. 
Table 5-13 Summary of Occupant Survey on Building Environment

\begin{tabular}{|l|c|c|}
\hline \multicolumn{1}{|c|}{ Subject } & Positive responses & Negative responses \\
\hline \hline Lighting & $77 \%$ & $23 \%$ \\
\hline Noise & $85 \%$ & $15 \%$ \\
\hline Ventilation & $83 \%$ & $17 \%$ \\
\hline Building Preference & $92 \%$ & $8 \%$ \\
\hline Temperature & $75 \%$ & $25 \%$ \\
\hline General Environment & $92 \%$ & $8 \%$ \\
\hline
\end{tabular}

Two questions were asked on the topic of lighting, but stated differently. One asked how the occupant would rate the light level, while the other asked a general question about lighting in the workspace. Both survey questions generated consistent responses. All the returned surveys responded to this question. Seventy-seven percent of the survey respondents indicated that they were satisfied with lighting at the TTF, while $23 \%$ indicated some dissatisfaction. Within the $77 \%$ satisfactory responses, $46 \%$ indicated they were very satisfied, while $31 \%$ indicated that they were somewhat satisfied. Twelve of the 13 responses answered the general question on light in the workplace. Nine occupants $(75 \%)$ responded that light levels are about right, two occupants (17\%) responded that there is too little light, and one occupant $(8 \%)$ responded that there is too much light.

NREL also asked the occupants about their satisfaction with regard to ventilation. Ten occupants (83\%) were satisfied with the ventilation at the TTF while two occupants $(17 \%)$ were dissatisfied. Within the $83 \%$ satisfied response, $67 \%$ were very satisfied and $17 \%$ were somewhat satisfied.

The occupants were then asked about their satisfaction with the noise level. Eleven occupants (85\%) were satisfied with noise levels at the TTF while two occupants $(15 \%)$ were dissatisfied. Within the $85 \%$ satisfied response, $62 \%$ were somewhat satisfied and $23 \%$ were very satisfied.

Occupants were also asked if they would move to a conventional building if given the choice. Twelve occupants $(92 \%)$ chose the TTF, while one occupant $(8 \%)$ chose a conventional building.

Written comments were also collected from the survey. These comments are presented in Appendix F. In addition, many occupants noted that the on/off cycling of the electric lighting system was bothersome and distracting. A lesson learned is that dimming fixtures are recommended for use in areas where constant light level is important.

Many of the occupants appreciated the fact that the TTF is a low-energy building. However, because there are no occupant controls, overriding the building must be done by NREL Site Operations personnel. Staff would like some ability to control the environment, especially temperature. It is recommended that some user-based temperature controls be provided, especially for working during the off-hours.

Results of the survey indicate an overall positive response toward the TTF's building environment.

Overall, the IEA survey instrument was more difficult to use than was warranted. Asking questions of the occupants and documenting their responses obtained the most valuable insights. An area of future work is to create a robust survey mechanism for buildings based on the initial IEA Task 21 work. 


\section{Subsystem Evaluations}

\subsection{Daylighting Analysis}

This section presents an analysis of the daylighting system. The occupant survey discussed in Section 5.5 provided important feedback, but NREL completed an additional analysis of the TTF to determine the building's workspace illumination characteristics. The daylighting system is critical to the overall energy performance of the building because $30 \%$ of the load in a typical office building is lighting (see Section 1.1).

Based on the space requirements related to ceiling height, a stair-stepped roof design worked well with the programming requirements and provided the opportunity for good daylighting. Because of the TTF's large rectangular floor area, the design team decided the easiest mechanism for daylighting was from overhead. NREL selected a clerestory concept during the design stage because it allowed the windows to be shaded by overhangs and controlled window coverings during the summer.

Exterior horizontal overhangs, placed over the view-glass and clerestory windows, minimized unwanted direct summer sun and allowed some direct gain during the heating months. Because the sun is higher in the sky during the summer, indirect daylight enters the building by bouncing light off the roof to the ceilings adjacent to the clerestories. To control brightness and possible glare resulting from the viewglass and clerestory windows, glazing was selected with specific visual transmittance properties, as previously described in Section 4.3. View window glazing was selected with a lower visual transmittance property than the clerestory windows. In addition, brushed-aluminum blinds were installed on the viewglass windows. Because of glare complaints caused by a direct beam hitting the center core wall and bouncing into the office space, an additional row of horizontal blinds was added on the lower clerestory windows. These clerestory blinds are adjusted twice per year (spring and fall equinox). The blinds are completely opened during the summer months to allow as much indirect light into the building as possible.

During the winter, when the sun is lower, the blinds are tilted upward to reflect incoming direct sunlight to the ceiling surfaces and allow the passive solar gains to enter the building. Occupants adjust viewglass blinds as needed. Direct daylight is provided by allowing sunlight to directly enter the building without being blocked by the overhangs (Figure 3-11 and Figure 3-12).

A high-reflective (greater than $80 \%$ ) white finish was added on interior surfaces to support the daylighting features of the building; however, cubicle walls, furniture, and carpeting placed in the openoffice area have a reflectance less than 50\%. The layout of the office pods also places some computer workstations at a $45^{\circ}$ angle (or more) to view-glass, which results in reflected glare problems for people in office cubicles with view-glass. Additional glare problems result from direct gain in the high-bay laboratory area. Horizontal blinds were not placed over the high-bay clerestory windows because of the height of clerestory windows from the floor and the associated difficulty of installing and adjusting the blinds.

Office cubicle spaces are characterized as having 12-ft $(3.6-\mathrm{m})$ ceilings with a corrugated ceiling structure (80\% reflectivity). A row of view-glass spans the entire south wall, incorporating windows with a height of $3.5 \mathrm{ft}(1.1 \mathrm{~m})$ and a visual transmittance of $38 \%$. The windows are located $2.5 \mathrm{ft}(0.8 \mathrm{~m})$ above the ground and are $4 \mathrm{ft}(1.2 \mathrm{~m})$ high. Perimeter office cubicles have direct views of the outdoors and interior cubicles have no exterior view. Some cubicle spaces also receive additional daylight from the first set of clerestory windows. Half the cubicle space receives light from a highly reflective (greater than $80 \%$ ) interior wall (permanent central core), which reflects light directly into the interior cubicle space from this set of clerestory windows (Figure 3-11 and Figure 3-12). 
The hallway and mid-bay laboratory areas receive daylight from the first set of clerestory windows. This space is characterized as having $18-\mathrm{ft}(5.5-\mathrm{m})$ ceilings with a corrugated ceiling structure $(80 \%$ reflectivity). A clerestory window spans the entire length of the south stair-stepped wall at a placement height of $12 \mathrm{ft}(3.6 \mathrm{~m})$ and incorporates windows with a height of $3 \mathrm{ft}(0.9 \mathrm{~m})$ and a visual transmittance of $72 \%$.

The high-bay laboratory area receives most of its daylight from a second set of clerestory windows. In addition, some daylight enters through windows along the north wall as well as the first set of clerestory windows in the mid-bay area. This space is characterized as having 24-ft (7.3-m) ceilings with a corrugated ceiling structure ( $80 \%$ reflectivity). A clerestory window spans the entire length of the south stair-stepped wall at a placement height of $18 \mathrm{ft}(5.5 \mathrm{~m})$ and incorporates windows with a height of $3 \mathrm{ft}$ $(0.9 \mathrm{~m})$ and a visual transmittance of $72 \%$. Six windows measuring $2 \mathrm{ft}(0.6 \mathrm{~m})$ by $2 \mathrm{ft}(0.6 \mathrm{~m})$ are located at midheight on the north wall, periodically spanning its length. These windows have a visual transmittance of $72 \%$.

All view-glass has slightly reduced visual transmittance (tint) to minimize glare conditions from incoming daylight. All surfaces are painted a highly reflective (80\%) white color (except cubicles, carpeting and furniture). All daylit zones, with the exception of the conference room, incorporate daylighting control sensors, which are single-stepped (on/off) control systems. All spaces within the building incorporate occupancy sensors; if there is no occupant detection, the lights remain off.

\subsubsection{Qualitative Evaluation}

Photographs taken with daylight only were used to capture the qualitative impact of the daylighting in the space. Figure 6-1 shows a typical cubical office. Note the south window location. The corrugated ceilings show dark spots and shadows. Figure 6-2 shows a typical inner cube. Note the glare in the computer monitor from the light reflecting off the central core. The glare is not direct gain, but reflected light.

Figure 6-3 shows the mid-bay laboratory area, and Figure 6-4 shows the high-bay laboratory area under only daylit conditions. These areas receive some direct solar radiation because of the TTF's passive solar design. In the high-bay area, where there are no horizontal blinds on the clerestory windows, this direct gain causes localized glare. The direct gain is visible in Figure 6-4. Note that some of the north windows that were designed to balance the high-bay light have been blocked by the experimental apparatus on the left side of the photo. It would be helpful to be able to redirect clerestory light onto the ceiling to brighten the space.

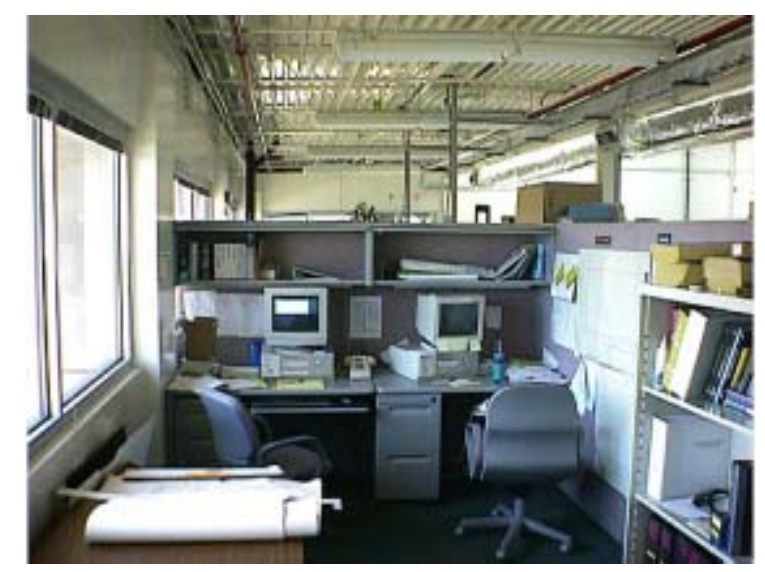

Figure 6-1 Perimeter office on sunny day with only daylighting (glazing is to the left of the photo) 


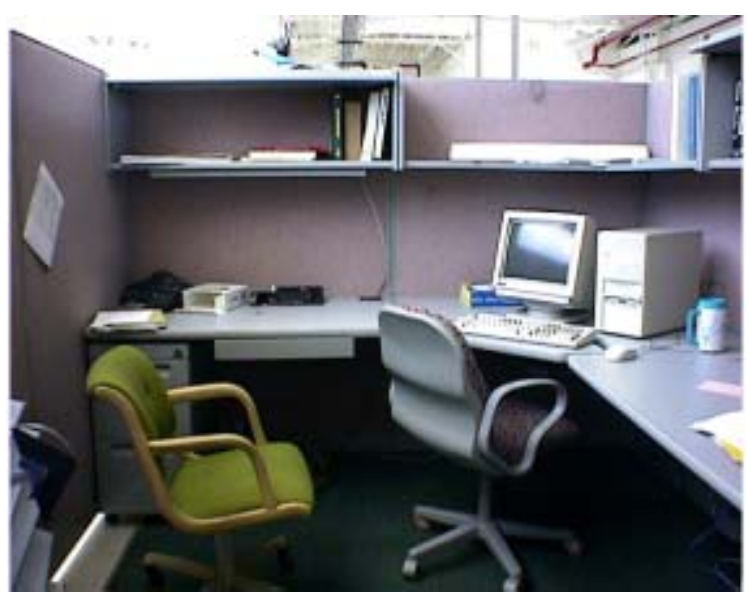

Figure 6-2 Interior office cubicle when illuminated by daylight only (south is to the right)

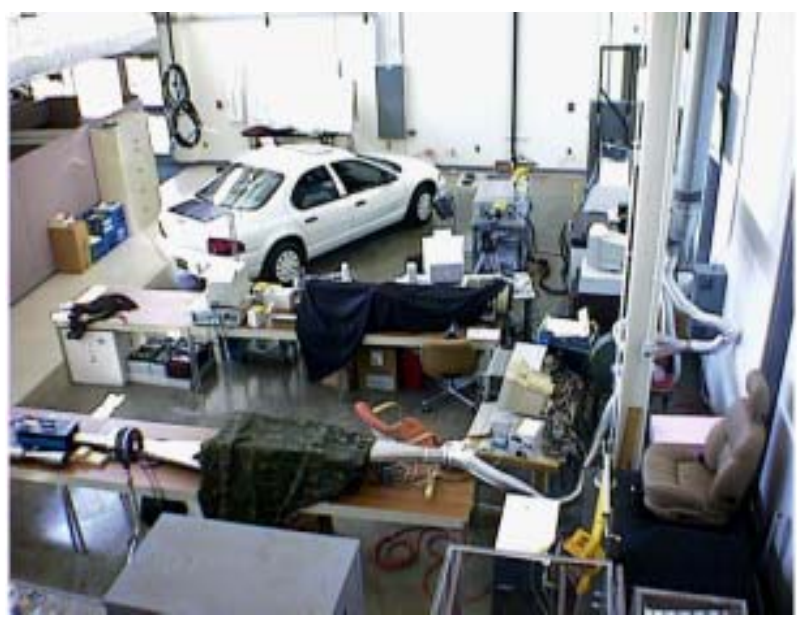

Figure 6-3 Mid-bay laboratory space illuminated by daylight (west end of buildingphoto taken to the west) 


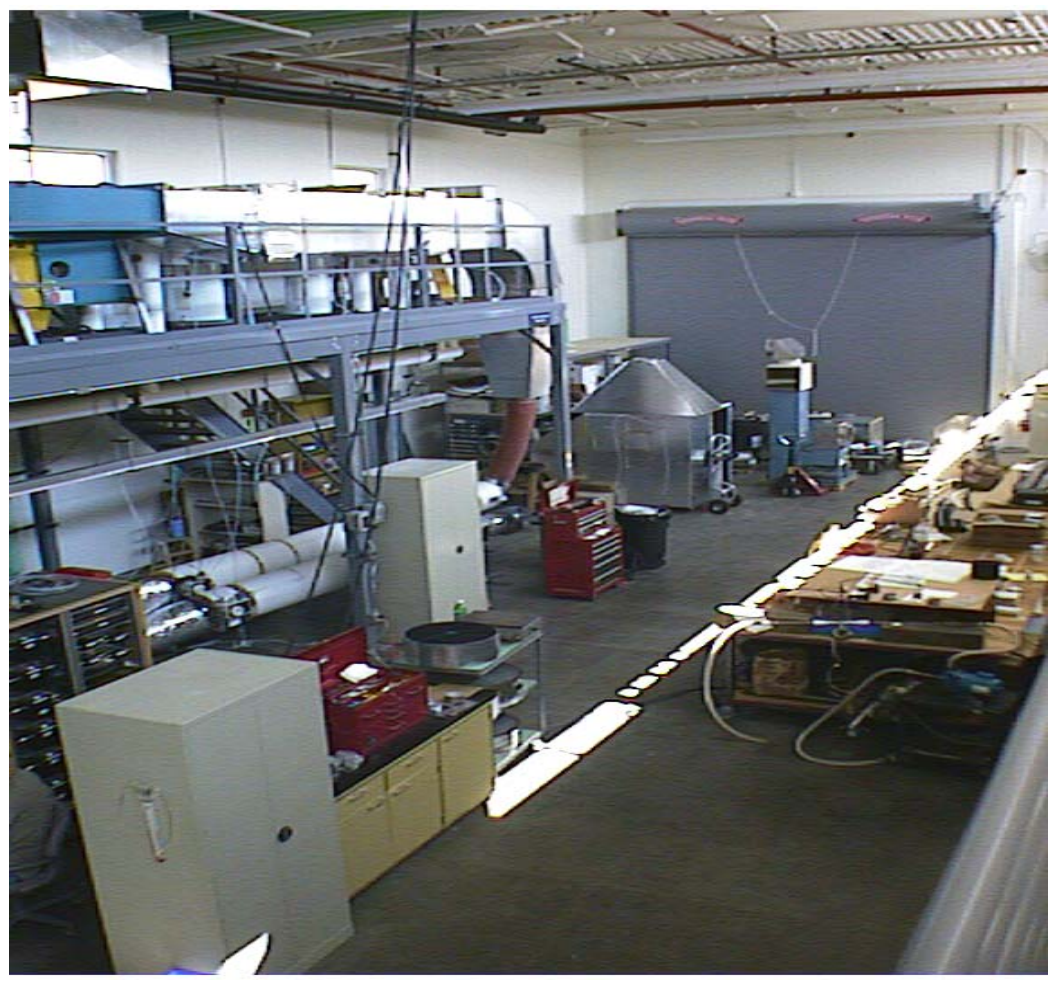

Figure 6-4 High-bay laboratory spaces illuminated by daylight (note direct gain stripe)

\subsubsection{Luminance Measurements}

Quantitative measurements were performed to better understand lighting in the TTF. Procedures for this evaluation followed protocols developed as part of the IEA/SHC-Task 21/Annex 29, Subtask D (Atif et al. 1997).

\subsubsection{Space Selection}

NREL selected seven daylit zones for the photometric analysis, each with individual lighting characteristics. Selections included: (1) perimeter office cubicle with view-glass, (2) interior office cubicles with reflecting center core, (3) interior office cubicles without a reflecting rear wall, (4) hallway, (5) mid-bay laboratory area, (6) high-bay laboratory area, and (7) conference room. This represents the entire building except the mechanical room, kitchen, restrooms, and closets - none of which are daylit.

\subsubsection{Instrumentation}

NREL measured each zone's horizontal luminance at the work plane $(2.5-\mathrm{ft}[0.8-\mathrm{m}]$ desk height and 3.5-ft [1.1-m] bench height depending on whether observations were made in an office or lab). In addition, NREL logged the operation of electric lights and measured the diffuse component of the exterior illumination (with a shadow-band photometer). Measurements were taken every 2 seconds and averaged over a 5-minute period. Sky conditions throughout the test periods were recorded on a daily basis.

Luminance readings were made simultaneously with a series of Li-Cor model LI-210SA photometric sensors. Each sensor is equipped with a Li-Cor model $2290 \mathrm{mV}$ adapter (a 604-ohm resistor) that allowed direct millivolt readings by the data-logger. NREL used a Campbell Scientific model CR10X datalogger to collect the luminance data (Table 6-1 shows measurement calibration factors) and placed sensors at the work plane (desktop or workbench height) in all monitored spaces. An exterior horizontal sensor was monitored simultaneously atop the TTF. A shadow-band was used to prevent direct solar illumination 
from striking the photometric cell. NREL calculated the compensation for the illumination blocked by the shadow-band according to sky conditions (Table 6-2). Declination adjustments were made as necessary to stay within one degree of true declination for each of the test days.

\subsubsection{Electric Lighting}

Meters recorded the energy flows to the electrical lighting circuits. The EMS directly controlled each daylit zone and therefore could record on and off times during the photometric analysis.

\subsubsection{Special Procedures}

NREL verified the sensor operation every hour to ensure unobstructed and unaltered photometric cells. The exterior photometer was cleaned daily and the declination adjusted as necessary.

Table 6-1

Photometric Calibration Data and Sensor Placement

\begin{tabular}{|l|l|c|c|c|}
\hline $\begin{array}{c}\text { Sensor } \\
\text { Identification }\end{array}$ & Location & $\begin{array}{c}\text { Calibration } \\
\text { Constant }\end{array}$ & $\begin{array}{c}\text { mV per } \\
\text { 100 Klux }\end{array}$ & $\begin{array}{c}\text { Logger } \\
\text { Multiplier }\end{array}$ \\
\hline 2797 & Shadow-Band & 17.20 & 10.39 & 9.626 \\
\hline 2479 & Interior Office & 6.42 & 3.88 & 25.773 \\
\hline 2780 & Hallway & 18.09 & 10.93 & 9.152 \\
\hline 2807 & $\begin{array}{l}\text { Interior Office w/o } \\
\text { Reflecting Wall }\end{array}$ & 16.68 & 10.07 & 9.926 \\
\hline 2482 & Mid-Bay & 19.42 & 11.73 & 8.525 \\
\hline 2473 & High-Bay & 7.52 & 4.54 & 22.026 \\
\hline 5593 & Perimeter Off & 33.26 & 20.09 & 4.978 \\
\hline
\end{tabular}

Calibration Constant $\times 1 A / 10^{6}$ uA $\times 604 \Omega \times 1000 m V / 1 V=m V / 100$ Klux

Table 6-2 Exterior Horizontal Illumination Sky Condition Correction Factor

\begin{tabular}{|l|c|c|c|c|}
\hline Time of year & $\mathbf{K}^{\prime}$ & $\begin{array}{c}\text { Clear Sky } \\
\mathbf{K}=\mathbf{K}^{\prime}+\mathbf{0 . 0 7}\end{array}$ & $\begin{array}{c}\text { Overcast } \\
\mathbf{K}=\mathbf{K}^{\prime}+\mathbf{0 . 0 3}\end{array}$ & $\begin{array}{c}\text { Partly Cloudy } \\
\mathbf{K}=\mathbf{K}^{\prime}+\mathbf{0 . 0 4}\end{array}$ \\
\hline June & 1.106 & 1.176 & 1.136 & 1.146 \\
\hline March & 1.092 & 1.162 & 1.122 & 1.132 \\
\hline
\end{tabular}

\subsubsection{Data Collection}

For data collection, NREL retrieved information from the Campbell Scientific CR10X as well as the building's EMS. Illumination measurements were made over a period that spanned several days near the spring equinox and summer solstice. Table 6-3 lists the monitoring dates. A considerable number of additional data about the lighting system performance were recorded, but NREL found it was not useful for evaluating the building's performance.

\subsubsection{Photometric Results}

Results show that a combination of illumination from incoming daylight and the electric lighting system provide all spaces within the TTF the required illumination. Most daylit zones receive enough daylight to meet illumination requirements. 
Electric lighting illumination was recorded at night. NREL verified that all lamps were operating and made sure they had been installed for a minimum of 6 months before the measurement. Table 6-4 lists recorded illumination values provided by the electric lighting system. Measurements were taken at locations identical to those used for the daylighting sensors; however, there is some variation in the spaces depending on fixture configuration.

Table 6-3 Photometric Monitoring Dates

\begin{tabular}{|l|l|}
\hline \multicolumn{1}{|c|}{ Test Period } & \multicolumn{1}{c|}{ Monitoring Dates } \\
\hline \hline Spring Equinox 1998 & Week of March 25 to 31 \\
\hline Summer Solstice 1998 & Week of June 26 to July 2 \\
\hline
\end{tabular}

Table 6-4 Electrical Lighting System Illumination Values and Sensor Placements

\begin{tabular}{|l|c|l|}
\hline \multicolumn{1}{|c|}{ Building Space } & $\begin{array}{c}\text { Luminance Provided by } \\
\text { Electrical Lights }\end{array}$ & \multicolumn{1}{|c|}{ Sensor Placement } \\
\hline Interior office space & $30 \mathrm{fc}(300 \mathrm{lux})$ & Center of southern desk \\
\hline $\begin{array}{l}\text { Interior office space w/o } \\
\text { reflecting wall }\end{array}$ & $35 \mathrm{fc}(350 \mathrm{lux})$ & Center of keyboard placement \\
\hline Perimeter office space & $30 \mathrm{fc}(300 \mathrm{lux})$ & Center of northern desk \\
\hline Mid-bay laboratory & $49 \mathrm{fc}(490 \mathrm{lux})$ & $5 \mathrm{ft}(1.5 \mathrm{~m})$ southeast from center \\
\hline High-bay laboratory & $37 \mathrm{fc}(370 \mathrm{lux})$ & Center of space (on workbench) \\
\hline Hallway & $34 \mathrm{fc}(340 \mathrm{lux})$ & Left of electrical panel box \\
\hline
\end{tabular}

\subsubsection{Office Daylighting}

Three different open-office cubicle configurations exist in the TTF: the perimeter office, the interior office near the center core, and the interior office away from the center core. The perimeter office cubicles receive daylight from a single row of view-glass lining the south wall. The interior office cubicles experience two types of daylighting conditions. One half the area only receives daylight from the above-mentioned view-glass, while the other half receives additional daylight from a clerestory window located in the mid-bay laboratory. Daylight entering through this clerestory window reflects off the highly reflective wall that forms the south wall of the permanent central core. Because the interior office cubicles located away from this center core wall do not receive reflected light, they receive the poorest level of incoming daylight.

Figure 6-5 shows the results for measured luminance near the spring equinox. Figure 6-6 shows results near the summer solstice. The first day of each test period shows excellent daylighting characteristics. On March 25, the figure shows that the daylighting control system turned on the electric lighting for the interior office cubicle when daylighting was insufficient. This space is the only daylit space that does not regularly receive adequate levels of daylight. Illumination levels increase around the equinox because more daylight enters the mid-bay clerestory during the spring and fall.

Periodic nighttime spikes in the data are caused by security personnel making their nightly rounds. The first day of each test period provides illumination values characteristic of clear weather days. Incoming daylight levels are greater during the spring because of the cut-off angles on the overhangs. 


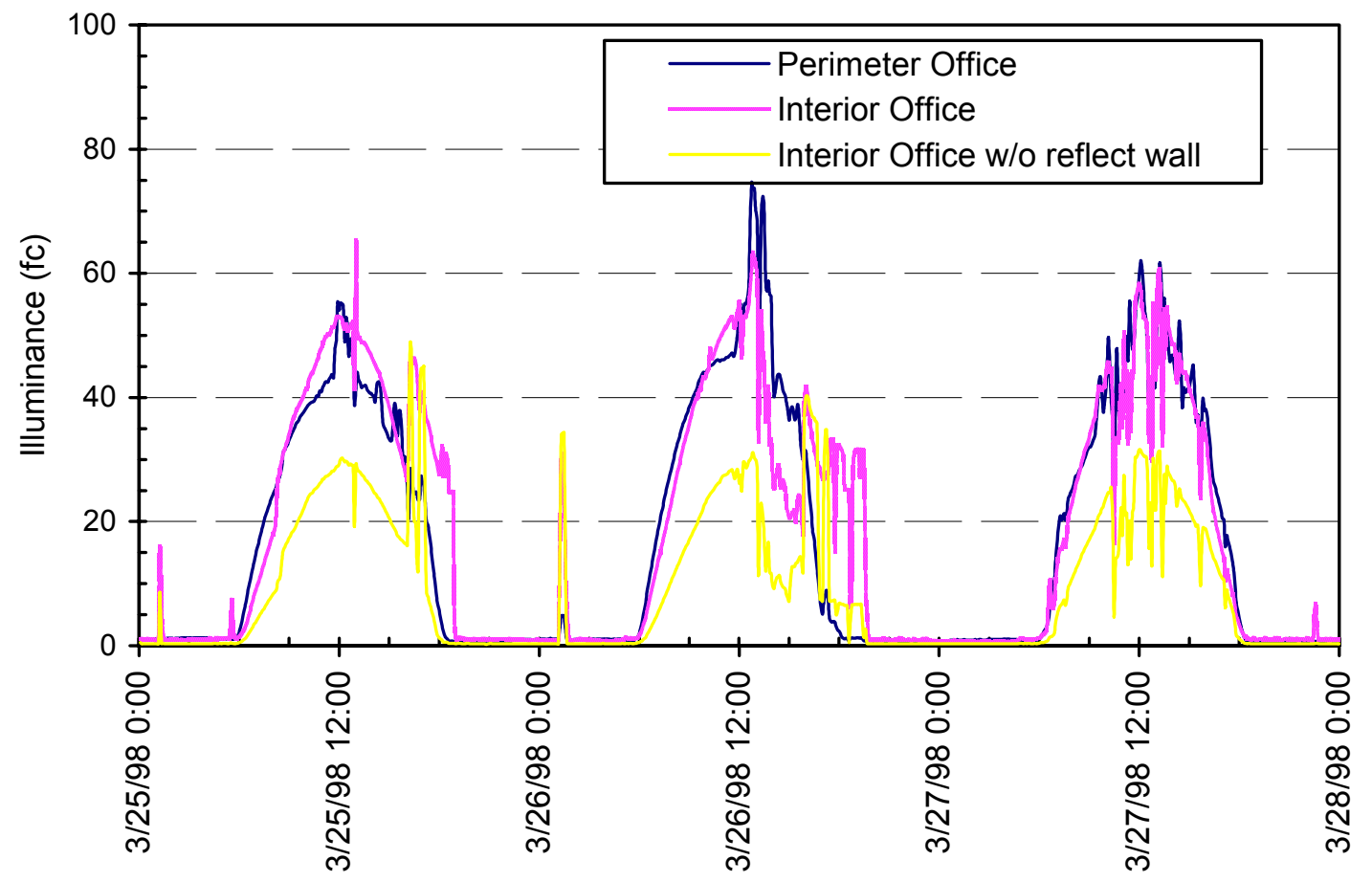

Figure 6-5 Office space photometric results: spring

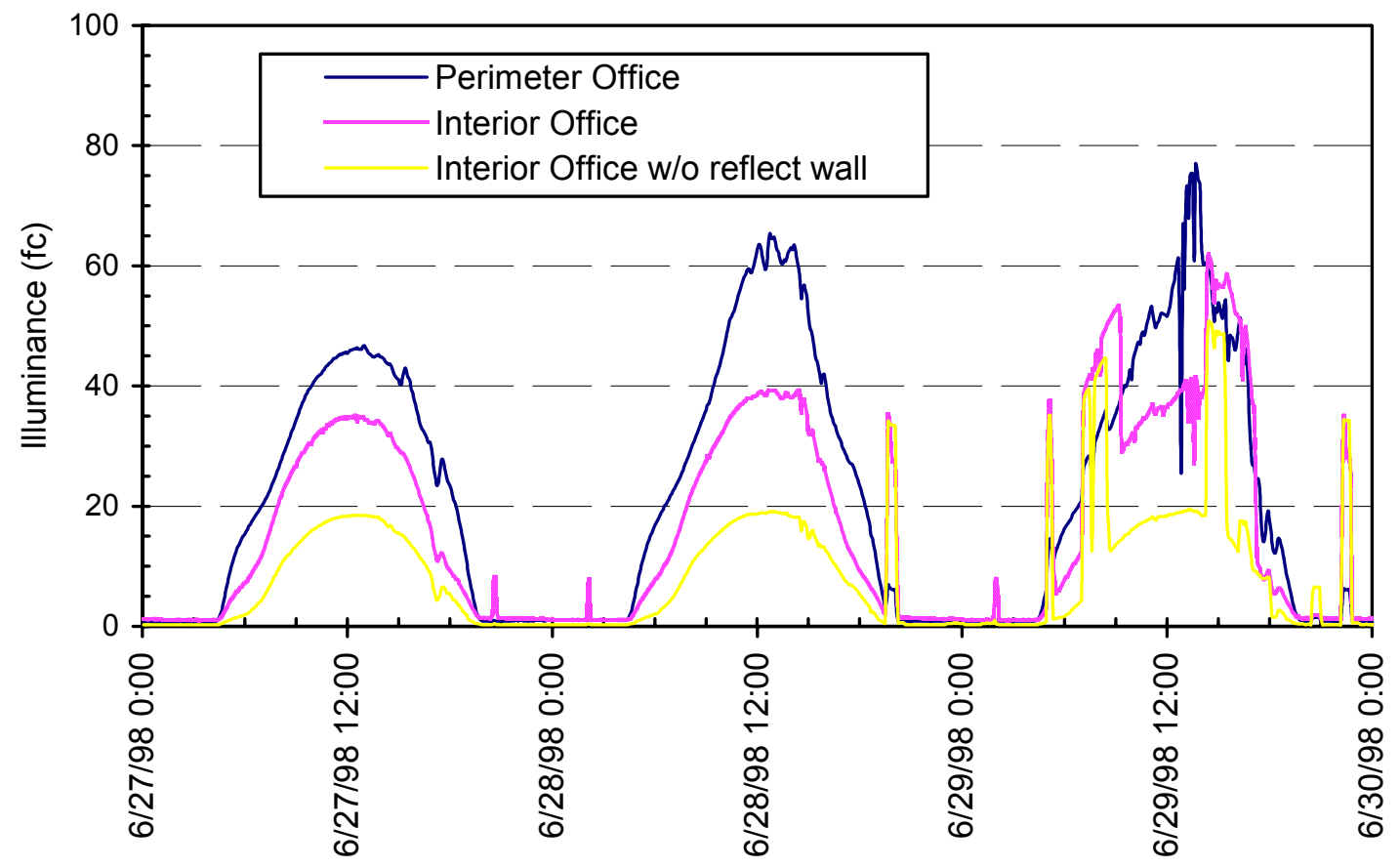

Figure 6-6 Office space photometric results: summer 


\subsubsection{Mid- and High-Bay Daylighting}

Photometric results for the mid-bay and high-bay laboratory areas show that adequate levels of incomisng daylight meet zonal lighting demands. Figure 6-5 shows results for illuminance levels in the mid- and high-bay spaces near the spring equinox. Figure 6-6 shows results near the summer solstice. The spikes in data are from the electric lights. Illuminance data fall within those specifications as set forth in the IESNA handbook, which indicates an approximate comfort level for open area office space of 300 lux (30 fc) at the work plane.

Although the high-bay laboratory area receives excellent illumination levels, it receives lower levels than the mid-bay area because the distance from the illuminated point to the light source increases. Periodic operation of the electrical lighting system occurs on all days except for June 28. Figure 6-3 and Figure 6-4 show the mid-bay and high-bay laboratory areas when illuminated by daylight only.

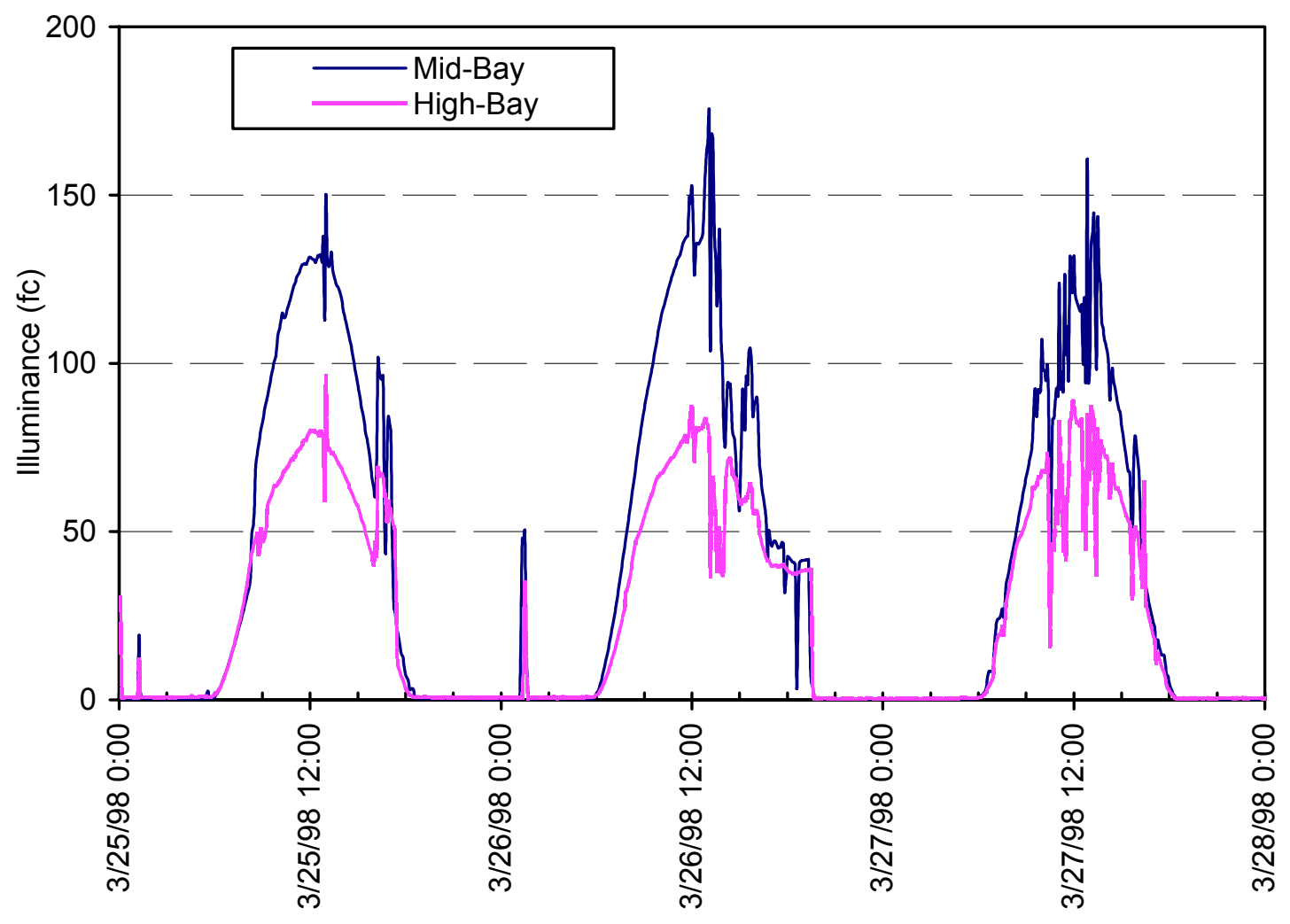

Figure 6-7 Mid-bay and high-bay laboratory photometric results: spring 


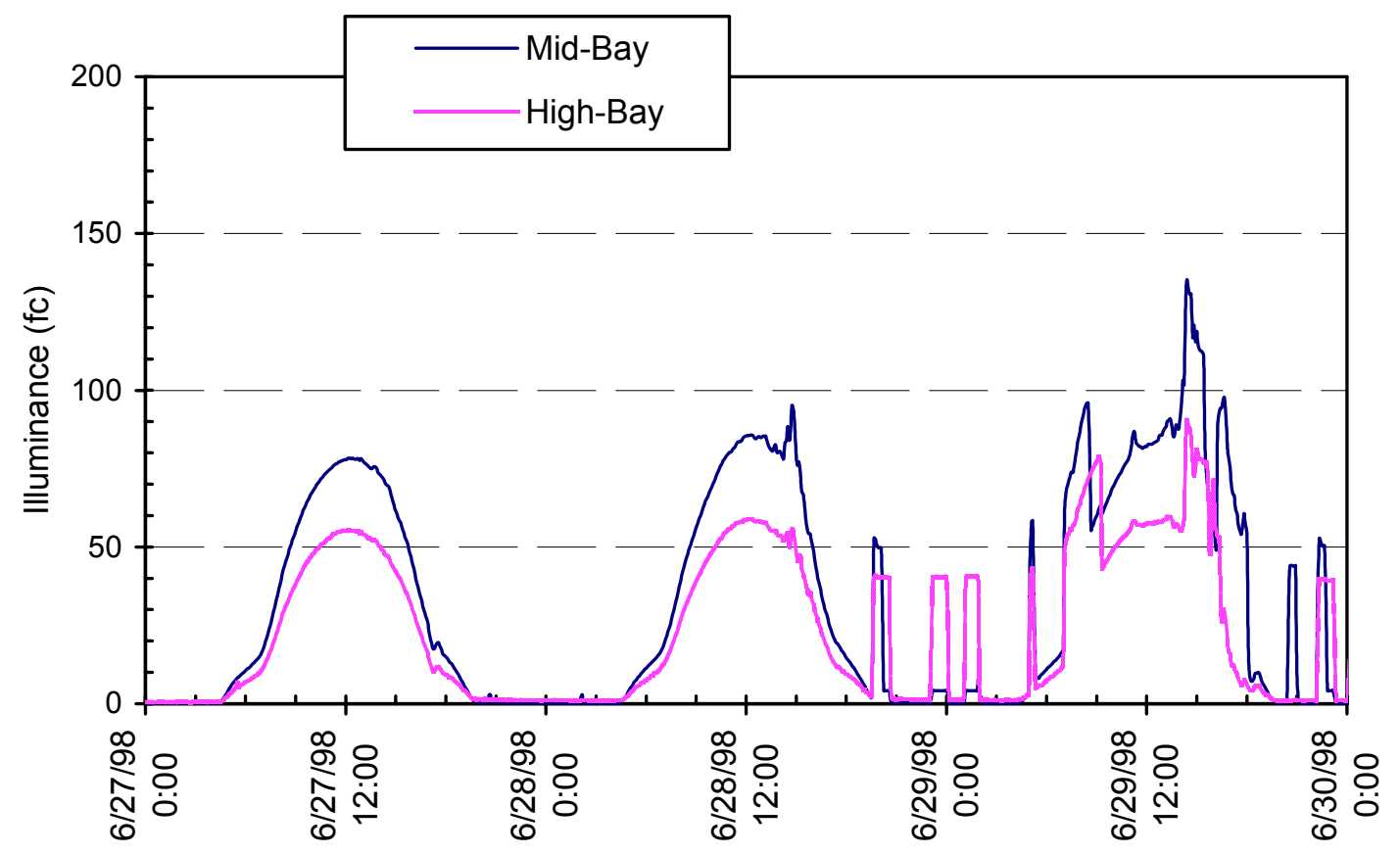

Figure 6-8 Mid-bay and high-bay laboratory photometric results: summer

\subsubsection{Hallway Daylighting}

Photometric results for the hallway area show that illumination requirements are met entirely by natural light entering through the mid-bay clerestory windows. Figure 6-9 shows the hallway results in spring, and Figure 6-10 shows the hallway results in summer. Luminance levels are far greater during the spring than during the summer because of the overhang design and low-sun angles. Spring luminance is so great that glare can sometimes result. Blinds were installed in the mid-bay clerestory windows to minimize this problem. Although test measurements were taken with the blinds in the raised position, they typically remain in the lowered position throughout the fall, winter, and spring. Blinds are adjusted to reflect incoming daylight toward the ceiling to further diffuse incoming direct solar radiation and they are never entirely closed. 


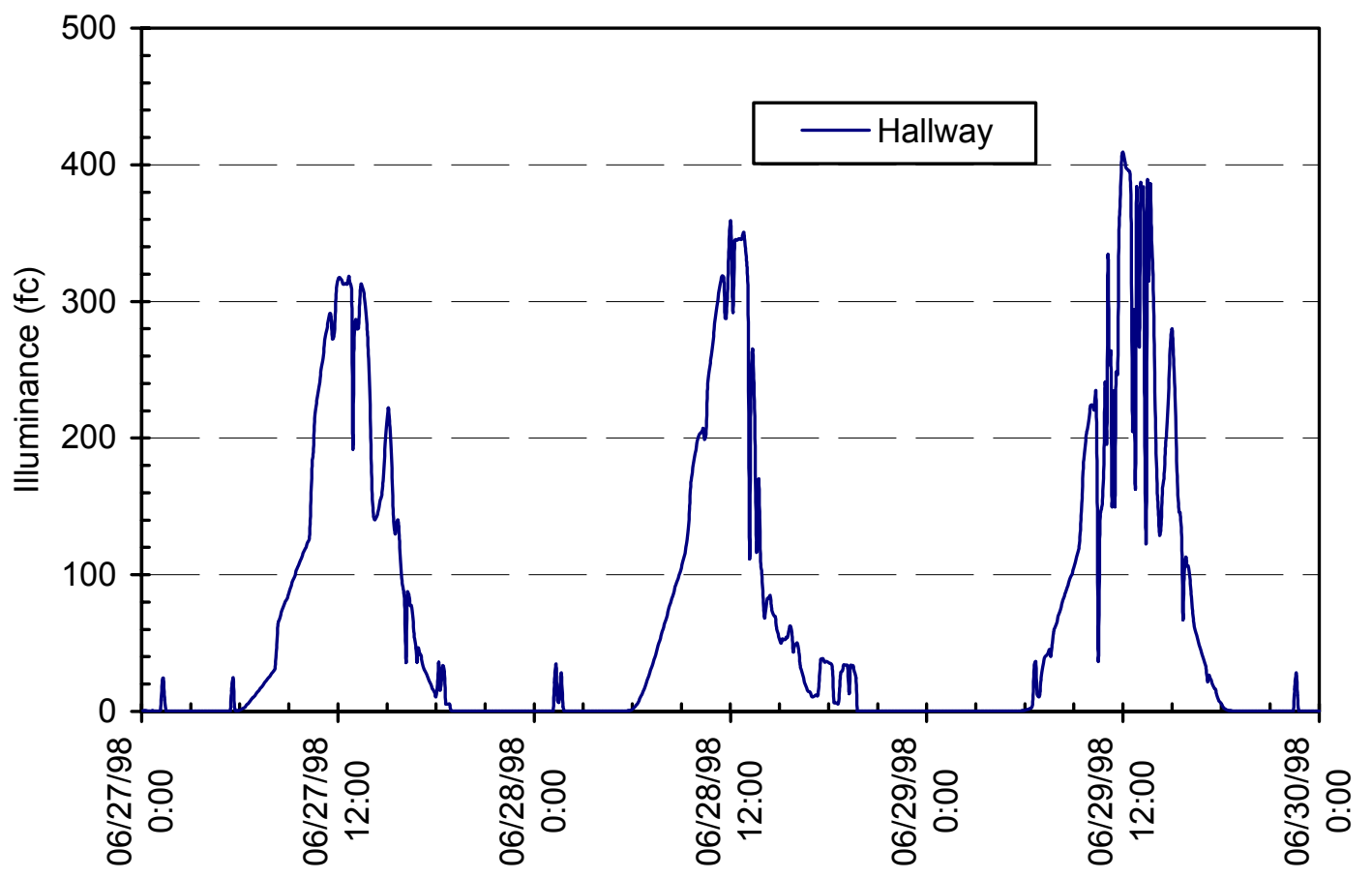

Figure 6-9 Hallway photometric results: spring

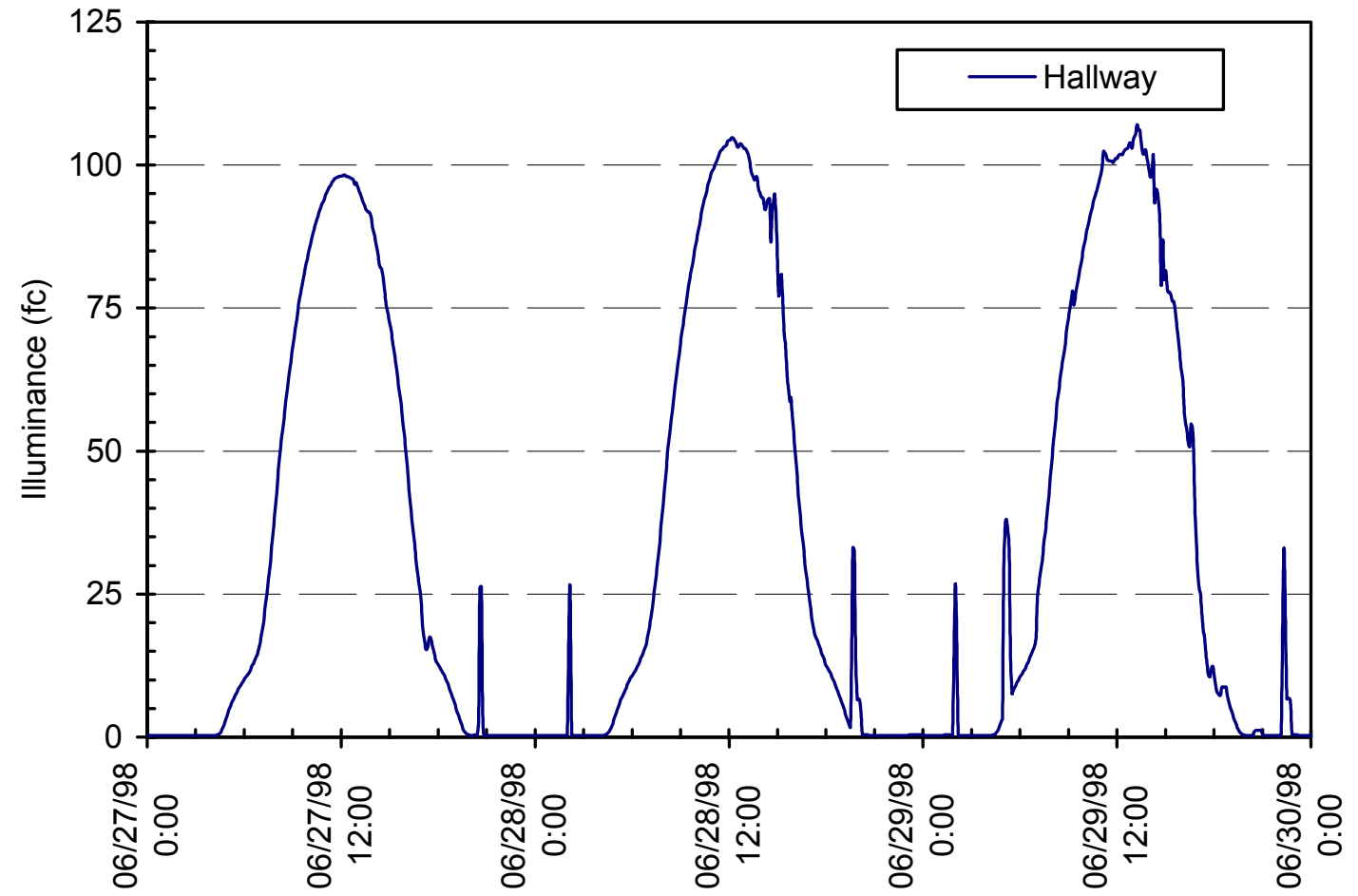

Figure 6-10 Hallway photometric results: summer 


\subsubsection{Daylighting Results}

This section summarizes important results and perceptions of occupants with regard to the TTF's daylighting. Qualitative and quantitative assessments of the TTF's daylighting performance show that the building's daylighting design substantially reduced energy use for electric lighting and delivered a reasonably well-lit indoor environment. The lighting and daylighting systems produced the largest energy cost saving for the TTF. As discussed in Section 4.4, the lighting system is a combination of daylighting strategies, efficient lamps and fixtures, and occupancy sensor controls. Lighting energy was reduced by $74 \%$, with an annual energy cost saving of $\$ 3,066$. Results show that a combination of illumination from incoming daylight and the electric lighting system provide all spaces with the required illumination in the TTF. Most daylit zones receive enough daylight alone to meet illumination requirements. Glare mitigation strategies were necessary for the clerestories. Blinds were installed in the mid-bay clerestory windows to minimize this problem. Although test measurements were taken with the blinds in the raised position, they typically remain in the lowered position throughout the fall, winter, and spring. Blinds are adjusted to reflect incoming daylight toward the ceiling to further diffuse incoming direct solar radiation and they are never entirely closed.

In testing the lighting system, the building occupants had some observations.

1. Ceiling appears dark. When lights are off, the overall contrast ratio between the ceiling and the work plane is low due to a combination of the off-white ceilings and the shadows from the corrugations on the ceiling deck.

2. Occupants have a sense the building is "off." That is, people are used to working in spaces where the lights are on and sometimes have a feeling that something is "wrong." There are some negative perception issues with looking at lamps that are "off."

3. Stepped, on/off controls are distracting to the occupants. Dimming controls would be expected to be an improvement.

\subsection{Thermal Comfort Analysis}

NREL conducted a comfort analysis with respect to ASHRAE Standard 55-1992 (ASHRAE 1992). This standard specifies the combinations of indoor space environment and personal factors that will produce thermal environmental conditions acceptable to $80 \%$ or more of the occupants within a building space. According to the standard, it is impossible to specify a thermal environment that will satisfy everyone. It is assumed that fewer than $20 \%$ will be dissatisfied when the recommendations of the standard are followed. Note that this analysis is a one-time test of the HVAC's ability to provide comfort and not whether the building is maintained at a comfortable point. Additional testing would be required to fully evaluate the annual comfort performance of the space. The focus of this test is air velocities and changes in temperature induced by the HVAC system. Long-term testing would be required to fully evaluate the operation of the building with respect to thermal comfort. Long-term testing was outside the scope of this effort, but it would be appropriate for future research. Appendix B contains comfort data and calculations for each analyzed zone.

\subsubsection{Comfort Measurements}

\subsubsection{Assumptions}

The study assumes that building occupants engage in light, primarily sedentary activity. In addition, it is assumed that building occupants wear typical indoor clothing consisting of lightweight dresses or trousers, short or long sleeved shirts or blouses and occasional jackets or sweaters. Summer clothing insulation values are assumed to be 0.35 to $0.5 \mathrm{clo}$; winter insulation values are assumed to be 0.80 to 1.20 clo (ASHRAE 1997). 


\subsubsection{Measuring Conditions}

To determine the effectiveness of the building system at providing environmental conditions specified in the standard, NREL made measurements under the following conditions. Summer cooling conditions require that the outdoor-to-indoor temperature and humidity differences not be less than $50 \%$ of the differences used for HVAC design, under clear to partly cloudy sky conditions. Winter heating conditions require the same specification. However, it is required that the sky conditions be cloudy to partly cloudy. Interior spaces are to be tested when the zone is loaded to at least $50 \%$ of the design load. Table 6-5 shows that all summer conditions were met. Although some preliminary winter testing did occur, it did not follow the ASHRAE standard.

Five separate spaces were included in the comfort analysis representing zones with different thermal environments. Spaces included (1) a perimeter office cubicle, (2) an interior office cubicle, (3) the midbay laboratory area, (4) the high-bay laboratory area, and (5) the conference room.

NREL collected data for each of the five space conditions included in the study. Table 6-6 lists the types of data collected and the associated equipment used to collect the data. Measurements were taken on September 8, 1998. (The peak cooling loads occur at this time of year because of the low solar angles combined with warm weather.) Radiant temperatures were estimated using measured surface temperatures and angle factors according to equations given in Appendix C of ASHRAE Standard 551992. Measured surface temperatures were used in all calculations.

Table 6-5 Required Summer Conditions for Comfort Evaluation

\begin{tabular}{|l|c|c|c|}
\hline \multicolumn{1}{|c|}{ Condition } & Requirement & $\begin{array}{c}\text { Average } \\
\text { during testing }\end{array}$ & $\begin{array}{c}\text { Conforms to } \\
\text { Standard? }\end{array}$ \\
\hline \hline Outdoor Temperature & $\begin{array}{l}>81.5^{\circ} \mathrm{F} \\
\left(27.5^{\circ} \mathrm{C}\right)\end{array}$ & $\begin{array}{c}83.7^{\circ} \mathrm{F} \\
\left(28.7^{\circ} \mathrm{C}\right)\end{array}$ & yes \\
\hline Outdoor Humidity & $>38 \%$ & $56.6 \%$ & yes \\
\hline $\begin{array}{l}\text { \% of Design Load Met by } \\
\text { HVAC }\end{array}$ & $>50 \%$ & $100 \%$ & yes \\
\hline
\end{tabular}

Table 6-6 Comfort Analysis Data Types, Relevant Sensors, and Placement Sensors

\begin{tabular}{|l|c|c|}
\hline \multicolumn{1}{|c|}{ Parameter } & Type of Equipment Used & Sensor Placement \\
\hline \hline Outdoor Dry-bulb Temperature & Vaisala Humitter 50Y & Outdoors \\
\hline Outdoor Relative Humidity & Vaisala Humitter 50Y & Outdoors \\
\hline Indoor Relative Humidity & Hobo RH / Temp & Perimeter Office \\
\hline Sky-Conditions & Human Observance & Not Applicable \\
\hline Radiant Temperature of Space Walls & Inframetrics IR Camera & Center of Room \\
\hline Space Dry-Bulb Temperature & Thermocouple & $\begin{array}{c}4,24,43,67 \text { in. } \\
(10.2,61.0,170.3 \mathrm{~cm})\end{array}$ \\
\hline Space Air Velocity & $\begin{array}{c}\text { VelociCalc Hot Wire } \\
\text { Anemometer }\end{array}$ & $\begin{array}{c}4,43,67 \mathrm{in} . \\
(10.2,61.0,170.3 \mathrm{~cm})\end{array}$ \\
\hline HVAC Air Velocity & $\begin{array}{c}\text { VelociCalc Hot Wire } \\
\text { Anemometer }\end{array}$ & At Diffuser \\
\hline HVAC Supply Temperature & $\begin{array}{c}\text { VelociCalc Hot Wire } \\
\text { Anemometer }\end{array}$ & At Diffuser \\
\hline HVAC Air Discharge Rate & Delta EMS & At VAV Box \\
\hline HVAC Information & Human Observance & Not Applicable \\
\hline
\end{tabular}




\subsubsection{Cooling Season Results}

Appendix B provides additional details of results for thermal comfort. According to ASHRAE Standard 55-1992, summer operative temperatures should lie within the psychrometric coordinates that span between $73^{\circ} \mathrm{F}\left(22.3^{\circ} \mathrm{C}\right)$ and $79^{\circ} \mathrm{F}\left(26.1^{\circ} \mathrm{C}\right)$ at a relative humidity of $60 \%$, and between $74^{\circ} \mathrm{F}\left(23.3^{\circ} \mathrm{C}\right)$ and $81^{\circ} \mathrm{F}\left(27.2^{\circ} \mathrm{C}\right)$ at the $36^{\circ} \mathrm{F}\left(2.2^{\circ} \mathrm{C}\right)$ dew-point temperature. If the operative temperature lies within these guidelines, less than $10 \%$ of the building's occupants should be dissatisfied with building thermal comfort.

Table 6-7 lists the results for the five test zones. The operative temperature is defined as the uniform temperature of an imaginary black enclosure in which an occupant would exchange the same amount of heat by radiation plus convection as in the actual nonuniform environment. The operative temperature is calculated according to ASHRAE Standard 55-1992, using the mean radiant temperature and ambient dry-bulb temperature of a space. The perimeter office area experienced a relative humidity of $65 \%$ during the testing period. The indoor relative humidity lies above the recommended comfort criterion for a space. Because the TTF uses evaporative cooling, the building periodically experiences elevated indoor humidity levels.

ASHRAE Standard 55-1992 states that asymmetric radiation from hot and cold surfaces, and from direct sunlight, can cause local discomfort that can lead to unacceptable thermal conditions within a space. To limit local discomfort, radiant temperature asymmetry in the vertical direction should be less than $9^{\circ} \mathrm{F}$ $\left(5^{\circ} \mathrm{C}\right)$ and in the horizontal direction less than $18^{\circ} \mathrm{F}\left(10^{\circ} \mathrm{C}\right)$.

Table 6-7 Comfort Results for Operative Temperature

\begin{tabular}{|l|c|c|c|}
\hline \multicolumn{1}{|c|}{ Space } & Operative Temperature & Relative Humidity & $\begin{array}{c}\text { Satisfactory } \\
\text { Results? }\end{array}$ \\
\hline \hline Perimeter Office & $74.5^{\circ} \mathrm{F}\left(23.6^{\circ} \mathrm{C}\right)$ & $65 \%$ & $\begin{array}{c}\text { (Borderline } \\
\text { because of } \\
\mathrm{RH})\end{array}$ \\
\hline Interior Office & $74.3^{\circ} \mathrm{F}\left(23.5^{\circ} \mathrm{C}\right)$ & $56 \%$ & Yes \\
\hline Mid-bay Laboratory & $76.0^{\circ} \mathrm{F}\left(24.4^{\circ} \mathrm{C}\right)$ & $56 \%$ & Yes \\
\hline High-bay Laboratory & $77.0^{\circ} \mathrm{F}\left(25.0^{\circ} \mathrm{C}\right)$ & $56 \%$ & Yes \\
\hline Conference Room & $73.8^{\circ} \mathrm{F}\left(23.2^{\circ} \mathrm{C}\right)$ & $50 \%$ & Yes \\
\hline
\end{tabular}

Table 6-8 Asymmetric Radiant Temperature Comfort Results: Summer

\begin{tabular}{|l|c|c|c|c|}
\hline \multicolumn{1}{|c|}{ Space } & $\begin{array}{c}\text { East-West } \\
\text { Orientation }\end{array}$ & $\begin{array}{c}\text { North-South } \\
\text { Orientation }\end{array}$ & $\begin{array}{c}\text { Floor-Ceiling } \\
\text { Orientation }\end{array}$ & $\begin{array}{c}\text { Satisfactory } \\
\text { Results? }\end{array}$ \\
\hline \hline Perimeter Office & $0.3^{\circ} \mathrm{F}\left(0.2^{\circ} \mathrm{C}\right)$ & $0.1^{\circ} \mathrm{F}\left(0.1^{\circ} \mathrm{C}\right)$ & $0.4^{\circ} \mathrm{F}\left(0.2^{\circ} \mathrm{C}\right)$ & Yes \\
\hline Interior Office & $0.0^{\circ} \mathrm{F}\left(0.0^{\circ} \mathrm{C}\right)$ & $0.0^{\circ} \mathrm{F}\left(0.0^{\circ} \mathrm{C}\right)$ & $0.3^{\circ} \mathrm{F}\left(0.2^{\circ} \mathrm{C}\right)$ & Yes \\
\hline Mid-bay Laboratory & $0.0^{\circ} \mathrm{F}\left(0.0^{\circ} \mathrm{C}\right)$ & $0.0^{\circ} \mathrm{F}\left(0.0^{\circ} \mathrm{C}\right)$ & $2.1^{\circ} \mathrm{F}\left(1.2^{\circ} \mathrm{C}\right)$ & Yes \\
\hline High-bay Laboratory & $0.0^{\circ} \mathrm{F}\left(0.0^{\circ} \mathrm{C}\right)$ & $0.1^{\circ} \mathrm{F}\left(0.1^{\circ} \mathrm{C}\right)$ & $30.0^{\circ} \mathrm{F}\left(16.7^{\circ} \mathrm{C}\right)$ & No \\
\hline Conference Room & $0.4^{\circ} \mathrm{F}\left(0.2^{\circ} \mathrm{C}\right)$ & $0.1^{\circ} \mathrm{F}\left(0.1^{\circ} \mathrm{C}\right)$ & $0.0^{\circ} \mathrm{F}\left(0.0^{\circ} \mathrm{C}\right)$ & Yes \\
\hline
\end{tabular}


Table 6-9 Ramped Temperature Comfort Results

\begin{tabular}{|l|c|c|c|}
\hline \multicolumn{1}{|c|}{ Space } & Ramp Rate & $\begin{array}{c}\text { Within } \\
\text { Operative } \\
\text { Temperate } \\
\text { Guidelines? }\end{array}$ & $\begin{array}{c}\text { Satisfactory } \\
\text { Results? }\end{array}$ \\
\hline \hline Perimeter Office & $0.7^{\circ} \mathrm{F} / \mathrm{h}\left(0.4^{\circ} \mathrm{C} / \mathrm{h}\right)$ & Yes & Yes \\
\hline Interior Office & $0.7^{\circ} \mathrm{F} / \mathrm{h}\left(0.4^{\circ} \mathrm{C} / \mathrm{h}\right)$ & Yes & Yes \\
\hline Mid-Bay Laboratory & $0.6^{\circ} \mathrm{F} / \mathrm{h}\left(0.3^{\circ} \mathrm{C} / \mathrm{h}\right)$ & Yes & Yes \\
\hline High-Bay Laboratory & $0.6^{\circ} \mathrm{F} / \mathrm{h}\left(0.3^{\circ} \mathrm{C} / \mathrm{h}\right)$ & Yes & Yes \\
\hline Conference Room & $3.7^{\circ} \mathrm{F} / \mathrm{h}\left(2.0^{\circ} \mathrm{C} / \mathrm{h}\right)$ & Yes & No \\
\hline
\end{tabular}

Table 6-10 Draft Risk Comfort Results

\begin{tabular}{|c|c|c|c|c|c|}
\hline Space & $\begin{array}{c}\text { Allowable } \\
\text { Air Speed } \\
\text { (foot) } \\
\text { ft/min } \\
(\mathrm{m} / \mathrm{sec}) \\
\end{array}$ & $\begin{array}{c}\text { Actual Air } \\
\text { Speed } \\
\text { (foot) } \\
\mathrm{ft} / \mathrm{min} \\
(\mathrm{m} / \mathrm{s}) \\
\end{array}$ & $\begin{array}{c}\text { Allowable } \\
\text { Air Speed } \\
\text { (head) } \\
\text { ft/min } \\
(\mathrm{m} / \mathrm{s}) \\
\end{array}$ & $\begin{array}{c}\text { Actual Air } \\
\text { Speed } \\
\text { (head) } \\
\mathrm{ft} / \mathrm{min} \\
(\mathrm{m} / \mathrm{s}) \\
\end{array}$ & $\begin{array}{c}\text { Satisfactory } \\
\text { Results? }\end{array}$ \\
\hline Perimeter Office & $\begin{array}{c}35 \\
(0.18)\end{array}$ & $\begin{array}{c}15 \\
(0.08)\end{array}$ & $\begin{array}{c}35 \\
(0.18)\end{array}$ & $\begin{array}{c}17 \\
(0.09)\end{array}$ & Yes \\
\hline Interior Office & $\begin{array}{c}48 \\
(0.24)\end{array}$ & $\begin{array}{c}30 \\
(0.15)\end{array}$ & $\begin{array}{c}60 \\
(0.31)\end{array}$ & $\begin{array}{c}40 \\
(0.20)\end{array}$ & Yes \\
\hline Mid-Bay Laboratory & $\begin{array}{c}52 \\
(0.26) \\
\end{array}$ & $\begin{array}{c}15 \\
(0.08)\end{array}$ & $\begin{array}{c}53 \\
(0.27) \\
\end{array}$ & $\begin{array}{c}17 \\
(0.09)\end{array}$ & Yes \\
\hline High-Bay Laboratory & $\begin{array}{c}42 \\
(0.21)\end{array}$ & $\begin{array}{c}42 \\
(0.21)\end{array}$ & $\begin{array}{c}43 \\
(0.22)\end{array}$ & $\begin{array}{c}25 \\
(0.13)\end{array}$ & Yes* $^{*}$ \\
\hline Conference Room & $\begin{array}{c}24 \\
(0.12)\end{array}$ & $\begin{array}{c}40 \\
(0.20)\end{array}$ & $\begin{array}{c}30 \\
(0.15)\end{array}$ & $\begin{array}{c}50 \\
(0.25)\end{array}$ & No \\
\hline
\end{tabular}

Table 6-11 Comfort Results for Vertical Air Temperature Difference

\begin{tabular}{|l|c|c|}
\hline \multicolumn{1}{|c|}{ Space } & $\begin{array}{c}\text { Vertical Temperature } \\
\text { Difference }\end{array}$ & Satisfactory Results? \\
\hline \hline Perimeter Office & $0.2^{\circ} \mathrm{F}\left(0.1^{\circ} \mathrm{C}\right)$ & Yes \\
\hline Interior Office & $0.4^{\circ} \mathrm{F}\left(0.2^{\circ} \mathrm{C}\right)$ & Yes \\
\hline Mid-Bay Laboratory & $0.8^{\circ} \mathrm{F}\left(0.4^{\circ} \mathrm{C}\right)$ & Yes \\
\hline High-Bay Laboratory & $0.2^{\circ} \mathrm{F}\left(0.1^{\circ} \mathrm{C}\right)$ & Yes \\
\hline Conference Room & $4.8^{\circ} \mathrm{F}\left(2.7^{\circ} \mathrm{C}\right)$ & Yes \\
\hline
\end{tabular}


Table 6-8 shows for asymmetric radiant temperature differences from the summertime results for the TTF. Figure 6-11 shows the temperature distribution of the high-bay roll-up door during a summer morning. Incident morning sun heats up this door, causing comfort problems in this section of the highbay. As shown in Table 6-8, the floor-to-ceiling temperature distribution can be greater than $30^{\circ} \mathrm{F}$ $\left(16.7^{\circ} \mathrm{C}\right)$ in the high-bay, resulting in localized discomfort and additional cooling loads. A high reflectivity and high emissivity exterior paint, combined with a low emissivity interior paint, may reduce the heat absorbed by the door and reduce heat emitted to the space. Reducing heat emitted from this door would improve thermal comfort at the east end of the high-bay.

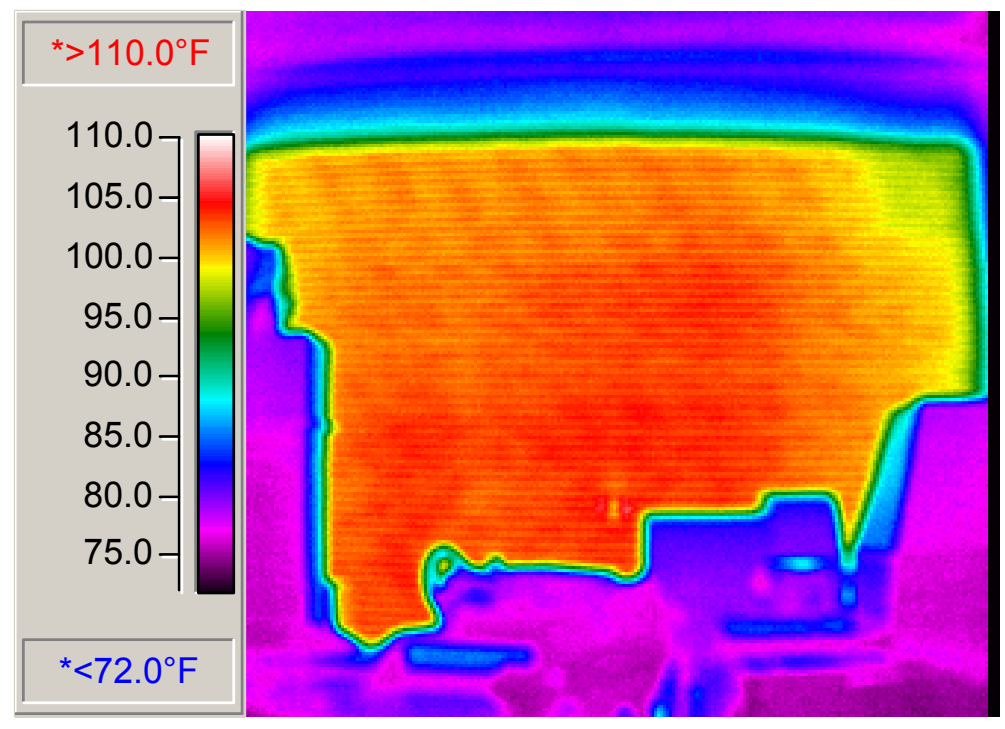

Figure 6-11 High-bay insulated roll-up door thermographic results

Standard 55-1992 states that the maximum allowable drift or ramp condition from a steady-state starting temperature is $1^{\circ} \mathrm{F} / \mathrm{h}\left(0.6^{\circ} \mathrm{C} / \mathrm{h}\right)$. The standard also indicates that this drift should not extend beyond the operative temperature guidelines. Table 6-10 summarizes the results of this analysis.

Results show that the conference room experiences far greater ramping temperatures than the allowable $1.0^{\circ} \mathrm{F} / \mathrm{h}\left(0.6^{\circ} \mathrm{C} / \mathrm{h}\right)$. The conference room's HVAC system is oversized (by roughly $100 \%$ ) in both capacity and airflow.

Standard 55-1992 states that elevated air speeds may cause unwanted local cooling of the body, defined as a draft. Draft risk depends on the mean speed, the turbulence intensity, and the temperature of the air. Sensitivity to draft is greatest where skin is exposed at the head and ankles. Results presented in Table 6-10 show that most spaces within the TTF are relatively free of risk from drafts. The high-bay laboratory area is very close to the draft-risk limit. However, increased levels of activity in this area alleviate any localized draft concerns. The increase in activity does cause some complaints about the temperature, even though it is within acceptable levels. The conference room is at high risk of localized drafts because of the conference room's oversized HVAC system. The fan delivers $1,600 \mathrm{cfm}(755 \mathrm{~L} / \mathrm{s})$ of conditioned air to the space, which occupies a little more than $400 \mathrm{ft}^{2}\left(37.2 \mathrm{~m}^{2}\right)$. It is recommended that this HVAC system be replaced.

Standard 55-1992 states that within operative temperature guidelines (as stated above), there is no minimum air speed that is necessary for thermal comfort. However, enough air velocity is needed to mix conditioned air and reduce stratification. The standard states that to prevent local discomfort, the vertical air temperature difference within the occupied zone measured at the 4-in. $(10.2-\mathrm{cm})$ and $67-\mathrm{in} .(170-\mathrm{cm})$ level shall not exceed $5^{\circ} \mathrm{F}\left(2.8^{\circ} \mathrm{C}\right)$. Table $6-11$ shows that vertical air temperature difference test results are acceptable under cooling conditions. 
Standard 55-1992 states that to minimize foot discomfort, the surface temperature of the floor for people wearing typical indoor footwear shall be between $65^{\circ} \mathrm{F}$ and $84^{\circ} \mathrm{F}\left(18.3^{\circ} \mathrm{C}\right.$ and $\left.28.9^{\circ} \mathrm{C}\right)$. Table $6-12$ shows that floor temperature comfort results are acceptable in all spaces.

\subsubsection{Heating Season Results}

Table 6-12 and Figure 6-12 present stratification results recorded during a winter test period. Although this preliminary analysis did not follow ASHRAE Standard 55-1992, it is important to note that stratification results approached the limits for vertical air temperature difference. Sensors were placed 4 in. $(10.2 \mathrm{~cm})$ and 30 in. $(76.2 \mathrm{~cm})$ above the floor, as opposed to Standard 55-1992's specification of the latter being at $67 \mathrm{in} .(170.2 \mathrm{~cm})$. Had the sensor placement been at this level, the results might indicate that the limits are being exceeded. Some building occupants indicated that the wintertime vertical temperature difference was too great, and that local discomfort did arise. NREL minimized the problem by programming the EMS to recognize stratification conditions and operate the appropriate ceiling fans at reduced speeds to mix stratified air. The results of this solution were not quantified.

Table 6-12 Floor Temperature Comfort Results

\begin{tabular}{|c|c|c|}
\hline Space & Floor Temperature & Satisfactory Results? \\
\hline Perimeter Office & $73.8^{\circ} \mathrm{F}\left(23.2^{\circ} \mathrm{C}\right)$ & Yes \\
\hline Interior Office & $73.8^{\circ} \mathrm{F}\left(23.2^{\circ} \mathrm{C}\right)$ & Yes \\
\hline Mid-bay Laboratory & $74.8^{\circ} \mathrm{F}\left(23.8^{\circ} \mathrm{C}\right)$ & Yes \\
\hline High-bay Laboratory & $74.8^{\circ} \mathrm{F}\left(23.8^{\circ} \mathrm{C}\right)$ & Yes \\
\hline Conference Room & $72.0^{\circ} \mathrm{F}\left(22.2^{\circ} \mathrm{C}\right)$ & Yes \\
\hline
\end{tabular}

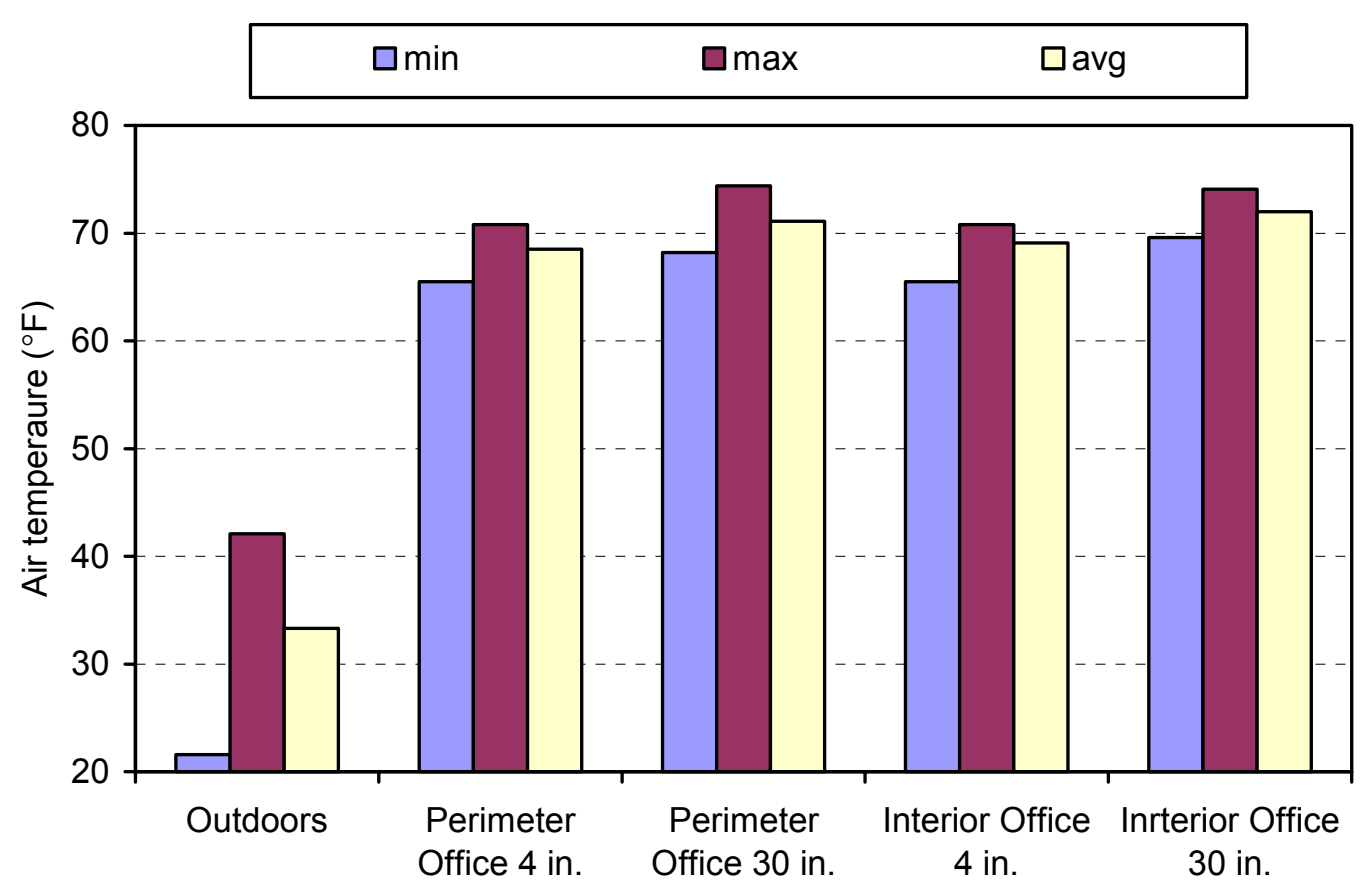

Figure 6-12 Comfort results for vertical temperatures during heating season 


\section{Economic Analysis}

High-performance buildings must be economically feasible to build and operate to be accepted by the building industry. This section provides an economic analysis identifying costs involved with construction of the TTF. It also shows the costs of the energy-efficient technologies used in the building and the overall simple payback.

The basic concepts used in the TTF represent a typical steel-frame building. Consequently, an independent contractor developed a cost estimate that compared building costs in the private commercial sector with the government sector in which the TTF was built. The TTF, like many building projects, did not have additional funds for energy efficiency techniques. The cost of the project was fixed by congressional limits. The challenge was to create a low-energy building within the constraints of the fixed-price project. Although additional dollars were spent on the up-front planning and the construction, energy savings are expected to offset the additional up-front capital investment.

\subsection{Building Costs}

The budget set for the TTF was $\$ 1,126,635$; it was built for $\$ 1,187,285\left(\$ 111 / \mathrm{ft}^{2}\left[\$ 1,196 / \mathrm{m}^{2}\right]\right)$. Appendix $\mathrm{C}$ lists the cost of expenditures. The change orders made up the difference with a cost increase of $5 \%$ $(\$ 60,650)$. Appendix D lists those costs attributable to change orders. The TTF subcontract was a design-bid-build contract with a fixed-price contract for construction. Careful design and the ability to work with the architect and builder allowed NREL to manage the building costs, while still integrating the energy efficiency design. The fixed-price situation forced the design team to create a building that met the programmatic and energy goals without increasing the cost. All amenities in the original program plan for the building were included in the final design except for the lay-in acoustic ceiling tiles in the low-bay area. The funds made available from this deduction were used to upgrade the HVAC system to a two-stage evaporative system. Not having the ceiling tiles does affect the aesthetics of the space and potentially some of the daylighting; however, these could be added later, if desired. It was important to make cost decisions based not only on energy efficiency and aesthetics, but also on the ability to add deleted items later, if so desired.

\subsection{Energy-Efficient Technology Incremental Costs}

Some of the energy-efficiency features increased building construction first costs; other features reduced first costs, such as the installation of a smaller HVAC system. The sum represents the cost of the energyefficient technologies (Table 7-1). Some energy-efficient technologies are considered incremental costs because they are used in lieu of conventional technologies. For example, an evaporative cooler has an incremental cost above a DX package system. Other technologies are considered additional costs, such as the daylighting design and occupancy sensors. The TTF's energy-efficient features added to first cost by $\$ 63,700$, but they decreased first costs by $\$ 17,200$. The difference, or the total incremental increase in first capital cost, is $\$ 46,500$, which is $3.9 \%$ of the total building cost. Of these additional costs, the energy analysis was subsidized by research program funds for studying how to achieve high-performance buildings. The remainder of the funds came from using less expensive finishes or items that could be added later, including lay-in ceiling tiles. 
Table 7-1 Cost of Energy-Efficient Features

\begin{tabular}{|c|c|}
\hline Additional Expenses: & Cost \\
\hline Reflective roofing at clerestories* & $\$ 300$ \\
\hline $\begin{array}{l}\text { Sensor controlled lighting } \\
\text { (17 sensors @ \$50,6 control points @ \$500/point) }{ }^{\star *}\end{array}$ & $\$ 3,850$ \\
\hline Increased building insulation package and reflective barriers* & $\$ 750$ \\
\hline Use of direct/indirect evaporative cooling versus DX cooling ${ }^{* *}$ & $\$ 12,000$ \\
\hline Installation of additional ceiling fan controls (22 points @ $\$ 500 /$ point $)^{\star * *}$ & $\$ 11,000$ \\
\hline Clerestories $^{* *}$ & $\$ 7,500$ \\
\hline Ventilation heat exchangers* & $\$ 6,000$ \\
\hline Low-e glass in clerestory* & $\$ 1,100$ \\
\hline Low-e glass in open-office areas* & $\$ 1,200$ \\
\hline Energy analysis (design phase)* & $\$ 20,000$ \\
\hline Subtotal for Additional Expenses & 63,700 \\
\hline \multicolumn{2}{|l|}{ Credits for features not needed } \\
\hline Use of ceiling fans for air de-stratification in lieu of conventional ductwork system* & $-\$ 12,000$ \\
\hline Xeriscape landscape $^{* *}$ & $-\$ 5,200$ \\
\hline Subtotal for Credits & $-\$ 17,200$ \\
\hline Total Incremental Capital Cost & $\$ 46,500$ \\
\hline
\end{tabular}

Other items contributed to the energy efficiency of the building; these items were not accounted for in the above analysis. NREL requires T-8 fluorescent lamps as standard design practice. At the time of design, this technology was considered new, but it had already been adopted by NREL facilities because of the previously completed Solar Energy Research Facility project.

NREL also uses an EIFS on smaller buildings as part of its design standard. An EIFS allowed NREL to include additional insulation on the exterior skin of the building and provide a tight construction.

Additional funds were included to account for additional roof and wall insulation, beyond the EIFS.

This project aggressively used Xeriscaping for landscaping. Although not directly tied to energy consumption, the landscaping reduced irrigation needs and plant costs.

\subsection{Simple Payback Analysis}

Simple payback determines how quickly the initial investment can be recovered. It is not a measure of long-term economic performance. A simple payback analysis divides the incremental capital cost of energy-efficient technologies by the annual energy savings. The total incremental capital cost of energyefficient technologies for the TTF was $\$ 46,500$. The analysis in Section 5.4.1 showed that the TTF saves $\$ 3,790$ per year in associated heating, ventilation, cooling and lighting costs. Therefore, the simple 
energy-efficient technology payback for the TTF (as built) is approximately $12 \frac{1}{2}$ years, including additional engineering costs. This information is for a federally procured project using design-bid-build.

\subsection{Incremental Capital Costs of a Typical Commercial Building}

An independent, third-party cost estimator ${ }^{4}$ evaluated the cost differences between the actual building and the building as if it had been built in the private sector. Table 7-2 lists the estimator's projection of the incremental costs (analogous to Table 7-1) for the TTF as if it were rebuilt in the private sector. The assumptions were that this building could be a typical small retail box or located in an industrial park for offices and light-industrial uses. The estimator determined that the TTF's energy-efficient features, if applied to a typical commercial building, would increase first cost by $\$ 35,350$. However, these features would also decrease first costs by $\$ 17,200$. The difference is a total incremental capital cost of $\$ 18,150$. In addition, the energy analysis could be simplified as experience is gained through further construction of this building type, decreasing such expenses in future projects.

The knowledge gained by using the TTF as a test bed can be used to determine which energy-efficient technologies make economic sense. Included in the mainstream pricing are lessons learned from the TTF experience. A single daylighting sensor was successful in the TTF and this is reflected in the private sector cost estimate. In addition, NREL simplified the ceiling fan controls to not reverse direction or use variable controls.

Table 7-2 Cost of TTF's Energy-Efficient Features for a Typical Commercial Building

\begin{tabular}{|l|r|}
\hline Additional Expenses: & \\
\hline Reflective roofing at clerestories & $\$ 300$ \\
\hline $\begin{array}{l}\text { Sensor controlled lighting used in conjunction with daylighting } \\
\text { (1 point @ \$500/point) }\end{array}$ & 500 \\
\hline Increased building insulation package and reflective barriers & 750 \\
\hline Use of direct/indirect evaporative cooling vs. DX electric cooling & 12,000 \\
\hline Installation of additional controls (2 points @ \$500/point) & 1,000 \\
\hline Clerestories & 7,500 \\
\hline Ventilation heat exchangers & 6,000 \\
\hline Low-e glass in clerestory windows & 1,100 \\
\hline Low-e glass in open-office areas & 1,200 \\
\hline Energy analysis & 5,000 \\
\hline Subtotal & $\$ 35,350$ \\
\hline & \\
\hline Credits for Technologies Not Needed & $-12,000$ \\
\hline Use of ceiling fans for air de-stratification in lieu of & $-5,200$ \\
\hline extensive ductwork system & $-17,200$ \\
\hline Xeriscape landscape & \\
\hline Subtotal & $\$ 18,150$ \\
\hline
\end{tabular}

\footnotetext{
${ }^{4}$ Karl Meader, an independent third-party contractor from Newstrom Davis Construction
} 


\subsection{Simple Payback Analysis Applied to a Typical Commercial Building}

The simple payback of energy-efficient technologies, if applied to a typical commercial building, is 5 years (net technology costs of $\$ 18,150$ at annual energy savings of $\$ 3,790$ ).

\subsection{Independent Total Cost Estimates}

The independent estimator was also given building plans and specifications without any prior knowledge of costs associated with the actual construction of the TTF. He provided three building cost estimates: (1) the building as it exists, (2) the building as it exists in the commercial environment, and (3) the building with the stair-step design, but without windows or clerestories in the commercial environment. Appendix E provides tables for these cost estimates that compare building costs in the commercial sector versus government procurement.

\subsubsection{Cost Estimate for Constructing the Existing Building}

From the building plans, the estimator generated a cost estimate for the TTF (built in the government sector) of $\$ 1,082,606\left(\$ 101 / \mathrm{ft}^{2}\left[\$ 1,090.9 / \mathrm{m}^{2}\right]\right.$ ) (Appendix C), a 3.9\% difference from the actual building budgeted costs. This first estimate proved the credibility of the cost estimate in comparison to the actual construction costs of the building.

\subsubsection{Cost Estimate for Constructing the Building in a Commercial Environment}

The estimator was then asked to produce an estimate for a building that was the same size and design as the TTF, but that was built in the private commercial sector. His estimate included the following specifications: (1) that the building was to be constructed on a flat lot and sized to provide code-required parking and landscaping as required in the Denver area; (2) the building construction was to be a bearing wall construction on continuous footings; (3) a combination of concrete tilt-up structure and steel framing was specified to support the structure; and (4) floor slabs were figured to be 4 in. $(10 \mathrm{~cm})$ throughout. A note on the tilt-up construction - this was done to make the comparisons equal. In most cases, a structural north wall would not be required for dirt retention. All interior finishes were to be commercial grade office finishes, with carpet in the office area and tile floors and wainscot in the restrooms. This building did not include the cost of the architectural wing-walls (side fins on east and west facades), which added approximately $\$ 10,000$ in additional EIFS coating requirements and associated design. (The wing-walls on the actual TTF were added by the architect and recommended by the NREL architectural review board.)

The estimated cost of building the TTF in the commercial sector was $\$ 984,613\left(\$ 92 / \mathrm{ft}^{2}\left[\$ 990 / \mathrm{m}^{2}\right]\right)$. This represented savings of $\$ 202,647$ or $17 \%$ of the actual building cost. Appendix E provides details about the commercial building's cost estimate.

The cost savings in the commercial estimate are largely a result of the following:

- A slightly shortened construction schedule (36 versus 44 weeks). This was based on experience of the estimator.

- A simplified foundation system. Bearing wall construction on continuous footings instead of the existing caisson system.

- Less extensive use of aesthetic detailing on the exterior building, such as the wing-walls and multiple slopes on the roof.

- Reduced electrical costs because of today's more competitive fixture and equipment prices.

- Decreased costs because of reduced reporting and administrative requirements of a federally funded government project. 
The simplification of foundation and architectural detailing would put the building on par with other commercial buildings built in the Denver area.

Appendix E also summarizes the findings of potential savings between the cost estimate of the TTF asbuilt construction as a federal building and the cost estimate of the TTF as a commercial building. Mr. Meader noted that $\$ 92 / \mathrm{ft}^{2}\left(\$ 992 / \mathrm{m}^{2}\right)$ for a building of this type and complexity is typical of the cost of similar buildings. As a reference point, public schools in Colorado were being constructed for $\$ 94 / \mathrm{ft}^{2}$ $\left(\$ 1,012 / \mathrm{m}^{2}\right)$.

\subsubsection{Cost Estimate for the Building without Windows in a Commercial Environment}

The independent estimator also provided an estimate for a commercial version of the TTF using the current design without any windows or clerestories. This building did not include the energy-efficient technologies applied at the TTF and was used to show only how much commercial buildings cost. The cost estimate was $\$ 929,635$ or $\$ 87 / \mathrm{ft}^{2}\left(\$ 937 / \mathrm{m}^{2}\right)$. The estimated cost savings for this building included all the savings mentioned in the competitive bid, savings in mechanical and electrical systems, as well as additional savings as a result of building without windows and reduced project management and supervision costs (Appendix E).

The assumption is that the building would be used as a nondaylit office or industrial building. Today, this is a very common type of building that is constructed in office parks and strip malls. The mechanical and electrical design is representative of a building that might have offices in the front with warehousing in the back.

\subsection{Recommendations for Further Cost Analyses}

The purpose of this analysis was to identify the building cost, the cost of the energy-efficient technologies, the technology payback, and to produce cost estimates for building the TTF in the commercial environment. The focus was on how quickly the initial investment can be recovered. It is recommended that the next step in analyzing the economic feasibility of the TTF is to produce a building life-cycle cost analysis. A building life-cycle cost analysis is an financial method of project evaluation in which all costs that arise from owning, operating, maintaining, and disposing of a project are considered. This analysis can be applied to capital investment decisions when determining the trade-off between higher initial costs and reduced future cost obligations. A building life-cycle cost analysis is a more accurate economic assessment of the long-term cost effectiveness of a project.

\subsection{Economic Conclusions}

It is possible to build a low-energy commercial building within the constraints of a fixed budget. Although analysis shows a $3.9 \%$ increase in costs directly related to energy efficiency improvements, it is probable that the costs would still have reached the maximum allowed under the fixed budget had the building been built without regard for energy consumption. The TTF represents an economically practical approach to obtaining high performance. 


\section{Lessons Learned and Conclusions}

\subsection{Lessons Learned}

This section discusses lessons learned from the evaluation of the TTF's energy performance and design process. The term lessons learned is used to refer to either positive or negative aspects of a project that have a clear message and might help subsequent building projects. The lessons are intended as recommendations, either for changes to this building, or changes that could be applied to similar buildings. The research effort for the TTF was primarily focused on using an integrated design process to create a low-energy building. By monitoring the building, it also provides an example that serves to motivate and educate architectural and engineering teams. Members of future building projects should keep these lessons in mind and realize that they should be considered jointly along with the goals for saving energy. Lessons learned are key educational components. They should help to improve future buildings. They can avoid the repeat of problems and to identify where the process of delivering buildings needs to be changed to promote extremely low-energy buildings. Documenting lessons learned from a building project can be a delicate matter. People involved in a project do not necessarily want to show where things went "wrong" because they could be held accountable for mistakes or "bad" judgment. Another problem with lessons learned is that a single project cannot necessarily be used to conclude that a particular lesson is true in general. Without a large number of case studies or repeatable building projects, lessons learned often appear to be anecdotal, rather than scientific. In addition, it is often a matter of opinion whether something is right or wrong. These difficulties appear to be unavoidable, given the sociological component of the building process and the fact that there is a lack of design expertise with very low-energy buildings and methods for rating them. All of these reasons point to the need for unbiased assessments of buildings with both successes and failures.

The TTF was an early example of the next generation of low-energy commercial buildings and much progress has been made since the project began in 1993. Therefore, many of the things that should have been done differently have already been incorporated into other building projects.

The lessons learned section of this report is organized around the stages of a building construction project from conceptual design through construction and performance analysis. Lessons learned on the design process through performance analysis are presented as general recommendations that are based on important successes and failures, as identified in the TTF case study. Lessons learned and recommendations for improvements on specific low-energy features are summarized in list form. Where needed, supporting explanations and references to other portions of the report follow recommendations.

\subsubsection{Conceptual Design Phase}

Section 3 discussed the conceptual design phase of project.

\section{Recommendation \#1. Assemble a project team committed to a low-energy building.}

Recommendation \#1 follows from a success of the TTF project. The TTF was predisposed to become a low-energy building because the owner (DOE and NREL) wanted it to be that way. Because the original design team was composed of experienced and genuinely interested members, the completed building is exceedingly similar to the original concept. The owner's awareness of energy concerns benefited the TTF at all stages of the project. Every team member must buy into the goals of the project, but leadership from building owners appears to be the most important when setting goals. NREL research staff, which had the role of in-house energy analysts, did not join the team until the beginning of the design development phase. It became apparent that energy consultants should have been part of the design team 
from the very beginning of a project to influence the earliest decisions that may have important implications for energy use.

\section{Recommendation \#2. Set quantifiable energy performance goals.}

Although TTF designers in the earliest stages made a firm commitment to reduce building energy requirements, there was no agreed-upon specific goal for the level of energy savings that were targeted by the project. For conceptual design, the goal was to have a low-energy building. At design development, this goal was quantified as a 70\% energy cost saving compared with a building built to just meet standard 10 CFR 435. Through the course of the project, it became apparent that energy performance goals should be set as part of the conceptual design phase. Early clarification of requirements related to building energy use helped the design team produce a building that meets the energy design goals by providing guiding principles at all points in the design process.

Goals should also include clear specification of how performance is to be defined, including whether the savings are in terms of energy use or energy cost, how baseline/benchmark performance levels are determined, and how equipment/plug loads are to be treated. The complexity of such issues related to performance metrics became apparent through the course of the TTF project and remains an active area of research.

\section{Recommendation \#3. Consider energy use consequences of programmatic requirements and early design decisions.}

The architectural program is developed early in the project and can have important implications for the eventual energy use of the building. Programming decisions affect the overall size or floor area of the building and the placement of certain spaces. For the TTF project, requirements were eventually changed to include an elevated mechanical mezzanine, which effectively increased the usable floor area and improved energy use intensities. A focus on daylighting also resulted in moving the conference room from an interior core space to the perimeter. The TTF program also had conference room occupancy of 30 people. This contributed to disagreements between the mechanical engineering firm and NREL over the estimated heating and cooling loads of the conference room zone. The mechanical engineering firm did not include shade management and wanted to size the HVAC system using estimated room occupancy of 30 people. Because of the mechanical engineer's concern about latent loads (from occupants), a separate HVAC system was specified for the conference room. A nominal 4-ton, packaged unit, DX roof-mounted HVAC unit was chosen to serve the TTF's conference room (section 5.3.2). (NREL recommended that if a separate system had to be used, it should be a small split system with the condenser located inside the building. The engineer would not reduce the size of the system, but agreed to locate the packaged unit inside the building as a compromise. Occupancy levels do not approach 30 people, and had the architectural program specified a more realistic occupancy level, the mechanical firm would not have used such a high occupancy level. The mechanical engineering firm also advised against using evaporative cooling for the main cooling source, because the cooling loads could not be met $100 \%$ of the time. NREL considered it acceptable to not meet comfort standards for the 8 hours per year predicted by modeling and installed evaporative cooling. A better situation would have been to specifically include a relaxed criterion for thermal comfort in the original program so that it would be easier for designers to specify alternative, low-energy systems and designs.

Programmatic documents should include a realistic expectation on typical occupancy, schedules of occupancy, and whether daylighting can be used. Note that at the programming stage, indicating no daylighting must have strong programmatic rationale - such as a photographic darkroom. In this project, the restrooms should have been daylit and are occupied for longer periods than anticipated. 


\subsubsection{Design Development Phase}

Section 3 discussed design during the development phase of the project.

\section{Recommendation \#4. Use energy models to guide design decisions.}

This recommendation is derived from success experienced with the TTF project. Extensive computer modeling of the TTF was essential in making design decisions early in the design development phase. This was used to guide the size of the windows, overhangs, insulation values, glazing types, and to provide preliminary insight to the mechanical systems. It would have been useful to create the base case during the conceptual design to provide meaningful, concrete targets. To manage the process, the envelope was designed first with HVAC and lighting systems being designed to meet the loads the envelope could not meet.

\section{Recommendation \#5. Results of detailed modeling should be used to assist in sizing equipment.}

Because whole-building energy modeling has been underused in the past, it is important to know ahead of time if design team members are comfortable relying on simulation predictions when they contradict other methods such as rule-of-thumb. HVAC systems are commonly sized with extra capacity so that buildings will be able to handle unanticipated loads that may develop in the future. The engineer wanted to size the systems based on typical buildings and past experience, not on the detailed modeling results, as they were not familiar with this advanced modeling. Much of the discussion revolved around the internal loads from lighting. Daylighting could meet most of the lighting needs and reduce the building's internal loads compared to typical commercial buildings. However, this was not fully considered. The highest cooling loads occurred during two periods: (1) during the summer when overhangs are effective at shading windows and considerable natural light is available, and (2) when the sun is low and direct gains enter the space. In the later case, outside air can typically meet the cooling loads. NREL performed computer models that predicted much lower loads from lighting and solar gains than those the engineers estimated using their own methods for calculating lighting and solar loads. In the end, a compromise was made - the firm sized systems based on its estimates either using the lighting or the solar loads, but not both. The tools that the engineers were comfortable using for sizing equipment did not account for lowenergy features such as daylighting and overhangs.

\section{Recommendation \#6. Foster communication between energy analysts and engineers.}

Communication and cooperation between the energy consultant and the mechanical engineer is essential to help projects succeed. The energy simulations performed by the consultant can show loads and provide alternatives for mechanical and electrical design, as well as architectural. It is important to choose an entire design team that can demonstrate excellent communication skills, a strong commitment toward working together, and a willingness to embrace nontraditional building designs and technologies. Many architectural and engineering firms follow traditional practices and hesitate to embrace decisions based on energy simulations, rather than experience.

\section{Recommendation \#7. Find methods of diffusing (or switching) liability problems for the engineer of record.}

The recommendation stems from liability problems faced by the engineer of record if equipment or systems are undersized. Although detailed legal recommendations are outside the scope of this report, experience with the TTF shows that liability can be a problem in constructing low-energy buildings. Perhaps contract language can be developed that limits liability of designers from possible ill effects of nontraditional, low-energy design, with the understanding that there may be slight comfort issues with undersized or alternative systems (such as evaporative coolers). Alternatively, contract language could be developed that creates a shift of responsibility to the designers, and makes them liable for meeting energy performance goals. It is important, however, that equipment and designs, including lighting and HVAC systems, function as specified. This is very different from sizing to meet loads. 


\section{Recommendation \#8. Write clear and complete specifications for unique energy features.}

Nontraditional buildings and systems require special care in documenting details of the design. Without adequate specifications, construction crews revert to traditional solutions when encountering construction difficulties. This may turn out to be at odds with energy-saving features and original design intent. Several of the construction aberrations that occurred with the TTF could have been avoided by providing better specifications (Section 4).

\section{Recommendation \#9. Design the control system to be fully integrated with the capabilities of equipment and building operators.}

A low-energy building may have a unique design philosophy and nonstandard equipment and sensors that require special emphasis to be placed on designing control systems. A traditional approach to designing control systems may not meet the needs of coordinating HVAC and lighting systems in a low-energy building. For example, with the TTF, there was a problem with not being able to turn the fans off inside the fan-powered VAV boxes (these are used for heating, but not for cooling — note that this can also be considered a specification issue). The human-building relationship must be also be considered during design and implemented properly so that occupants and operators can interact with the features of a lowenergy building.

\subsubsection{Construction Phase}

\section{Recommendation \#10. Inspect buildings with concern for the building's energy features.}

Vigilant field verification of how the building is constructed can help to ensure that intended energy features are actually included in the building. An understanding of how the building differs from its design can be invaluable in assessing the reasons why the building displays a certain level of performance. In the case of the TTF, knowing that proper foundation perimeter insulation was not installed helped designers understand how envelope heat losses could be affecting heating and comfort conditions. Other examples of problems encountered with the TTF project include foundation insulation, relief damper position, daylighting sensors/controls, and window frames.

\subsubsection{Tuning and Alterations Phase}

\section{Recommendation \#11. Budget for postcommissioning tuning and alterations.}

The usual commissioning activities do little to improve the operation of a building beyond its design capabilities. Follow-up procedures that are intended to tune, alter, and adjust the operation of the building are just as important. Experience with the TTF shows that after a building exists (and has been commissioned to verify its system components are as designed) there is a significant need to adjust/change lighting and HVAC controls to further reduce energy use and improve occupant satisfaction. Predictive capabilities during the design phase are not perfect, and once the building is up and running there should be an opportunity to revisit the design and make changes. Preprogrammed controllers do not always take full advantage of potential energy-saving measures and may need to be reprogrammed.

The obvious expense of postcommissioning tuning/alterations, which in the case of the TTF took a "fleet of PhDs" as one engineer commented, suggests the need to develop more advanced control systems to facilitate such activities. The "black box" method of control could work with simple interfaces, if they are designed to maximize the energy savings potential. There is a need to develop robust controllers related to technologies used in this building for implementation on other buildings. These technologies include evaporative cooling, daylighting systems, and variable-speed supply fan systems. 


\subsubsection{Performance Analysis}

\section{Recommendation \#12. Maintain computer energy models.}

Energy models used during the design phase of the project should be retained and updated for subsequent use in evaluating performance. Models should be updated to "as-built" to account for any changes from the intended design. Retaining computer models from the design phase saves effort in developing calibrated and as-built models.

\section{Recommendation \#13. Provide accurate as-built plans.}

Like the energy models, plans should be updated to reflect as-built and as-operated construction. Likewise, sequence of operations should be updated to reflect final set points and strategies. Specification templates should be updated to reflect weaknesses that were discovered during construction.

\section{Recommendation \#14. Evaluate whether energy goals were met.}

Although the energy saving goal was not completely met $(63 \%$ HVAC $+\mathrm{L}$ savings versus the $70 \%$ HVAC + L savings goal), the process of verifying the performance was helpful. A specific methodology for quantifying energy performance should have been agreed to as part of setting goals. Evaluating the performance provides important feedback to design teams for use with the next project, but the subject building can also benefit if the building performs well below expectations and faults can be identified and corrected.

\section{Recommendation \#15. Use dedicated equipment for detailed monitoring.}

This study used the building's EMS to collect performance data. Although EMS systems often have the ability to record data for trending purposes, it was difficult to obtain complete data sets. The EMS system did not store data in a robust way, nor were separate PC systems able to routinely and reliably interrogate the EMS and store data. The PC's operating system was unreliable and it was difficult and time consuming to merge separate data files. The difficulties encountered in the TTF project in collecting, storing, and merging monitored data led to a recommendation that future such efforts use dedicated data logging systems that are specially designed for robust monitoring. It also highlighted the need for special purpose software that merged data sets obtained from EMS. A complete energy balance on metering is essential to find faults in monitoring.

\section{Recommendation \#16. Maintain records of design intent and performance analysis.}

NREL developed this recommendation from successes obtained within the TTF project. Because the operators of the TTF were also part of the design team, they understood how the building was intended to function. This knowledge proved enormously beneficial in efforts to evaluate performance as well as tune and alter the building after commissioning. Because most projects do not incorporate operators as part of the design team, it is important that they have access to information about the building-especially with regard to the nonstandard features of extremely low-energy buildings. Building life-cycle information systems are the subjects of research activity and involve development of cross-platform data models (e.g., Industry Foundation Classes). NREL's experience with the TTF shows that retention of historical data is beneficial.

\subsubsection{Low-Energy Features}

All buildings have wish lists of things that should be done differently for the next building. The following is a summary list of such items relating to the energy features in the TTF.

- Ceiling fans should be set to the down position. Variable speed is not necessary for these fans. 
- Ceilings, walls, furniture, and floors should be bright white to help reflect daylighting. If possible, slope ceilings toward daylighting fenestration and use smooth surfaces to prevent shadowing on the ceilings. Make the ceilings appear brighter. A high-reflective (greater than $80 \%$ ) white finish was added on interior surfaces to support the daylighting features of the TTF; however, cubicle walls, furniture, and carpeting placed in the open-office area have a reflectance less than $50 \%$.

- Locate south windows higher on the wall — consider separating south windows between view glass and daylighting.

- Use a mini-split system appropriately sized for the conference room. Allow for an economizer cycle on the outside air as well as a heat exchanger that is properly ducted.

- Use diffusing glass or light deflecting panels on the clerestory windows to help reflect light to the ceiling to avoid direct glare.

- Use flat-screen monitors help to reduce glare on workstations. The layout of the office pods places some computer workstations at a $45^{\circ}$ angle (or more) to view-glass, which results in reflected glare problems for people in office cubicles with view-glass. Even though the monitor is not the bright spot, locating monitors facing away from the glass appears to work the best.

- Use linear T-8 fixtures in all areas. Even though compact fluorescent cans are more efficient than their incandescent counterparts, the T-8 fixtures have higher efficiency than both compact fluorescents and incandescent. Orient lighting zones parallel to primary source of daylighting so that spaces with the most daylighting can be dimmed separately from zones that receive less daylighting.

- Service areas are highly used and should employ daylighting. Use windows or other daylighting strategies to the center hallway and restrooms.

- Use dimming fixtures with on/off controls in the office areas to maintain constant lighting levels. Enable office area lights to operate only when building is occupied to prevent triggering from security patrols. (Keep hallway lights on occupancy/daylighting control.)

- Evaluate use of secondary transformers and minimize when possible. For metering purposes, HVAC loads had a dedicated secondary transformer for powering ceiling fans and the EMS panels. The transformer was a large parasitic to the building. A second HVAC meter could have been used on the plug panels to isolate the load, decrease overall cost, and improve efficiency.

- Install relief damper close to ceiling. Allow for natural ventilation. Consider operable windows for natural ventilation.

- Provide user accessible controls (user on/ auto-off capabilities) for night and weekend overrides and temperature control. Occupants would like some ability to control the environment, especially temperature. Occupants generally appreciate the fact that their building is a low-energy building. However, when there are no occupant controls, overriding the building must be done site operations personnel. It is recommended that some user-based temperature controls be provided, especially for working during the off-hours.

- Provide user accessible controls for the conference room. Sporadically controlled areas benefit from controls that default to no-occupancy with manual on and a timer-controlled off.

- Consider additional cooling loads and comfort problems due to large garage doors that experience incident solar radiation. The interior surface of the east garage door in the high-bay of the TTF can exceed $110^{\circ} \mathrm{F}\left(38^{\circ} \mathrm{C}\right)$ during morning summer hours. The objective is to prevent large radiant summer heat gains that cause comfort problems. Incident morning sun heats up these doors, causing comfort problems in the interior zones. A high reflectivity and high emissivity exterior paint, combined with a low emissivity interior paint, may reduce the heat absorbed by the door and reduce 
heat emitted to the space. Also, consider methods to shade large garage doors, such as placing the doors on the north of the building (when possible).

\subsection{Conclusions}

Table 8-1 provides the summary results of the energy costs, site energy use, and source energy use with associated savings. Compared to the energy performance of typical office building presented in Section 2, the TTF with typical office plug loads would be a low-energy office building that uses significantly less site energy with lower energy costs. The design goal for the TTF was to reduce the HVAC + L by $70 \%$. A calibrated simulation of the as-built TTF performs $63 \%$ better than an equivalent minimally code-compliant building in terms of providing the building occupants with thermal comfort, fresh air, and light. The percentage translates to an annual energy saving of $\$ 3,673$.

The TTF's actual performance is less than was predicted primarily because of:

- Thermally-broken window and door frames were not installed as specified. It is unclear when this item was removed from the design.

- A thermal bridge exists between the building foundation and an exterior retaining wall.

- Heat loss through the slab-on-grade floor because of poor perimeter insulation is more than the simulation models predicted.

If these elements had been included during construction, the original goal could have been met. This is an example of the importance of quality control during construction.

As determined by a parametric study of the building, incorporating daylighting strategies contributed the largest energy savings. Clerestories combined with daylighting controls reduced the use of electrical lighting. Reduced electrical lighting decreased the internal gains in the building thus decreasing cooling loads but increasing heating loads. Heating provided by passive solar gains helps to offset the reduction of heating by the lights. Cooling energy savings were also achieved through use of an indirect/direct evaporative cooling system and optimized building overhangs that reduced the cooling load from solar gains. Reducing the cooling load had the second largest impact on the total building energy savings.

Table 8-1 Cost, Site, and Source Energy Savings

\begin{tabular}{|c|c|c|c|c|c|c|}
\hline & \multicolumn{2}{|c|}{ Energy Cost } & \multicolumn{2}{|c|}{ Site Energy } & \multicolumn{2}{|c|}{ Source Energy } \\
\hline & $\begin{array}{c}/ \mathrm{ft}^{2} / \mathrm{yr} \\
\left(\$ / \mathrm{m}^{2} / \mathrm{yr}\right)\end{array}$ & $\begin{array}{l}\text { Percent } \\
\text { Savings }\end{array}$ & $\begin{array}{c}/ \mathrm{ft}^{2} / \mathrm{yr} \\
\left(\$ / \mathrm{m}^{2} / \mathrm{yr}\right)\end{array}$ & $\begin{array}{l}\text { Percent } \\
\text { Savings }\end{array}$ & $\begin{array}{c}/ \mathrm{ft}^{2} / \mathrm{yr} \\
\left(\$ / \mathrm{m}^{2} / \mathrm{yr}\right)\end{array}$ & $\begin{array}{l}\text { Percent } \\
\text { Savings }\end{array}$ \\
\hline Base Case & $\begin{array}{c}0.74 \\
(7.97)\end{array}$ & \multirow{2}{*}{$52 \%$} & $\begin{array}{l}49.1 \\
(558)\end{array}$ & \multirow{2}{*}{$41 \%$} & $\begin{array}{c}131 \\
(1488)\end{array}$ & \multirow{2}{*}{$49 \%$} \\
\hline As-built & $\begin{array}{c}0.36 \\
(3.88)\end{array}$ & & $\begin{array}{l}28.9 \\
(328)\end{array}$ & & $\begin{array}{c}66 \\
(752)\end{array}$ & \\
\hline
\end{tabular}

Conducting this study led to the following general conclusions:

- Within the constraints of a fixed budget, it possible to build a small commercial building that uses much less energy than a code-compliant building and maintain occupant satisfaction.

- The TTF represents an economically practical approach to obtaining high performance.

- Case studies of real buildings help identify important issues to address when trying to improve the process by which the lowest energy buildings can be designed, created, and operated. 
- A whole-building design approach facilitates developing low-energy buildings when used by an integrated design team working toward well-defined goals.

- Computer modeling tools were essential in refining the design decisions and to keep the building meeting the energy targets.

- Quality control during construction is important to ensure that energy features are included as designed.

- For the TTF, incorporating daylighting to reduce electric lighting provided the most significant energy savings.

- In a dry climate, indirect/direct evaporative cooling can provide sufficient cooling capacity with less energy use than refrigerant based cooling systems.

- Occupants are distracted and annoyed by stepped electrical lighting controls.

- Allowing direct beam solar to enter through daylighting from the clerestories can provide sufficient space lighting, but can cause glare problems.

- Security lighting can be placed on daylight and motion sensors and not stay on all the time.

- Monitoring is critical for identifying problem areas and providing the feedback on actual performance compared with simulated performance.

The TTF is a $10,000-\mathrm{ft}^{2}\left(929-\mathrm{m}^{2}\right)$ mixed office/light laboratory building that demonstrates how a number of efficient technologies and a design approach for energy-efficient buildings can be applied to create low-energy buildings in a number of commercial building sectors. The successful design and construction of a low-energy building was the result of the integrated energy-design process. Designers used computer simulations throughout the design process to minimize the energy cost. Designers were also required to stay within a certain budget so the TTF was constructed for about the same price as a non-energy-efficient building.

\subsection{Suggestions for Future Work}

This section summarizes improvements that could be made to the design, operation, and evaluation of the TTF. The TTF continues to offer a viable and accessible test bed for national laboratory researchers. In addition to conducting a variety of experiments within the TTF, the building provides opportunity to investigate methods of reducing energy use in commercial buildings.

\subsubsection{Controls}

Because the TTF is intended for such activity and researchers at NREL have full access, the building is a good candidate for research into advanced control hardware and algorithms. Advanced control strategies are emerging as important methods of improving energy efficiency in older buildings and new construction. The TTF's EMS is already capable of incorporating additional energy and cost saving features. The EMS has the capability of shedding noncritical building loads during peak energy cost periods, while automatically activating these loads during low energy-cost periods. For instance, if the building's electrical contract requires the building's owner to pay a penalty depending on the peak power draw, or if the price of electricity changes throughout the day, the EMS can automatically disconnect and reconnect predetermined, noncritical loads as it deems necessary, thereby creating a cost savings. This feature has yet to be applied because of NREL's current site-wide metering system. However, plans are underway to independently meter each building. Upon completion, each meter could be tied back to the EMS network where load-shedding capabilities can then be used. 
NREL has considered implementing a statistical database for monitoring occupancy. As the statistical database grows, predictions can be made for the use of various building components based on occupancy patterns. For instance, when security personnel make their nightly rounds, the EMS could observe the individual's movements and make an interpretation about how the pattern compares to typical behavior. Instead of setting the electrical lighting timer to the current one-hour-on setting for nighttime, the timer could be set to operate for only 5 minutes to save energy. A statistical database of occupancy patterns may also be used for predicting future needs for various zonal set points, including those pertaining to temperatures, dead bands, startup/shutdown times, and other schedule related issues. For instance, instead of controlling building operation based on strict weekly schedules, operation could be determined through a combination of scheduling and occupancy detection. The building could learn, for example, that an employee usually comes in on Saturday mornings to work and have the EMS warm up the building by the time the employee arrives. Because alternative work schedules are becoming more commonplace, control strategies like these could save energy while maintaining occupant satisfaction.

Statistical methods of performance analysis could also be applied to better detect system malfunctions. If current equipment performance does not match previous data recorded during similar conditions, the building's operator could be informed that a certain piece of equipment is about to malfunction or needs general service. In addition, the building operator could use Internet resources to access current predictions for local weather and use these data in the building's EMS to better optimize how the building is controlled.

\subsubsection{Lighting}

NREL would like to replace lighting equipment in the office and mid-bay areas to allow some of the single step (on/off) fixtures with continuously dimming ballasts/controls to be changed. Early findings show that building occupants are annoyed by dramatic changes when the electrical lighting system is turned off or on, which causes some occupants to perceive spaces as too dark, even when a space receives ample natural light. A continuous dimming control system may alleviate these problems and it would be worth evaluating at the TTF. The minimal on/off cycling of the fixtures in the hallway and high-bay did not result in occupant discomfort, as these areas received abundant daylighting. In the conference room, fluorescent fixtures have dimming ballasts with manual controls, and the suggestion has been made to add automated daylight controls with dimming.

NREL is conducting an ongoing evaluation of the fenestration products used for daylighting. Direct solar radiation is part of the passive design of the building. However, direct solar radiation in the TTF has cause unwanted glare, as well as localized elevated zone temperatures, and has lead to thermal and visual discomfort. NREL is currently evaluating the use of translucent daylighting products and horizontal light-shelves.

\subsubsection{HVAC}

Several improvements could be made to the evaporative cooling system. The indirect portion of the system currently scavenges air from inside the building, but it would be better to use outdoor air. Because the TTF has a built up central air handler, it was simpler to use indoor air rather than outdoor air because it involves less ducting. However, the outdoor humidity is usually lower than humidity inside the TTF because of the direct evaporative cooling and process loads (especially when the desiccant test loop is operating). The indirect evaporative section would likely be more effective with outdoor air. The air handler draws outdoor air from the south side of the building, which is preheated by the roof. The air would be cooler if drawn from the north side. The evaporative cooler control is currently based on drybulb temperatures; use of more sophisticated controls based on a real-time psychrometric analysis of the various air streams could improve the determination of the most efficient means of cooling. 
NREL also discovered several problems with the equipment that conditions the conference room. The most critical issue is that the system should be able to operate in economizer mode. The HEX should either have a bypass or be removed. In addition, the HEX ducts should be reconfigured to take advantage of the heat exchanger. The conference room's HVAC system is oversized (by roughly 100\%) in both capacity and airflow. Results show that the conference room experiences far greater ramping temperatures than the allowable $1.0^{\circ} \mathrm{F} / \mathrm{h}\left(0.6^{\circ} \mathrm{C} / \mathrm{h}\right)$. The large rooftop package is clearly oversized and it should be replaced with a mini-split system. If the package is retained, it should be retrofitted with a smaller blower that provides about half as much airflow.

In addition, $\mathrm{CO}_{2}$ sensor(s) could be installed and used to control the ventilation air fan in the main HEX. Currently the ventilation supply fan is operated on a schedule (and turn off when cooling draws outdoor air). The role that the ceiling fans play in distributing ventilation air has been overshadowed by their affect on thermal comfort. Installing $\mathrm{CO}_{2}$ sensors would allow quantifying if/when better mixing of ventilation air is needed. Additional research is needed on other indoor pollutants. The conference room provides an ideal test bed for small scale, highly variable loads.

\subsubsection{Analyses}

The analysis presented in this report represents efforts from the late 1990s, rather than current techniques. The earlier research on the TTF (and subsequent monitoring efforts) revealed many ways of improving on such investigations.

- Computer modeling programs have improved and current detailed analysis should use EnergyPlus rather than the older DOE-2.1E.

- Dedicated monitoring equipment should be used rather than trying to collect data from the EMS.

- More emphasis on monitoring receptacle and process loads would help the analysis. The effects of these loads are significant to the building heating and cooling systems.

- Daylighting and thermal comfort studies should be repeated and conducted at different times of the year. Further thermal comfort studies should focus on the evaporative cooling system's ability to meet the cooling loads caused by highly variable internal gains.

- A life-cycle cost analysis should be completed to enhance the simple payback method.

- Evaporative cooling systems use large quantities of water. The implications of water consumption need to be factored into an overall assessment. 


\section{References}

ASHRAE. (1989). Standard 90.1-1989: Energy-efficient Design of New Buildings Except Low-rise Residential Buildings. Atlanta, GA: American Society of Heating, Refrigerating, and AirConditioning Engineers.

ASHRAE. (1992). ASHRAE Standard 55-1992: Thermal Environmental Conditions for Human Occupancy (ANSI approved). Atlanta, GA: American Society of Heating, Refrigerating, and AirConditioning Engineers.

ASHRAE. (1997). ASHRAE Handbook of Fundamentals. Atlanta, GA: American Society of Heating, Refrigerating, and Air-Conditioning Engineers.

Atif, M.; Love, J.; Littlefair, P. (October 1997). Daylighting Monitoring Protocols and Procedures for Buildings. Institute for Research in Construction. Canada. Report \#T21/D2.1/97-01 for IEA Solar and Heating Program Task 21 Subtask D.

Balcomb, J. D.; Burch, J. D.; Westby, R.; Subbarao, K.; Hancock, C. E. (1994). "Short-Term Energy Monitoring for Commercial Buildings." ACEEE 1994 Summer Study on Energy Efficiency in Buildings, 28 August - 3 September 1994: Proceedings, Panel 5 Commissioning, Operation, and Maintenance. Washington, DC: American Council for an Energy-Efficient Economy; pp. 5.1-5.10

Deru, M. and Kirkpatrick, A. (2001). "Ground-Coupled Heat and Moisture Transfer from Buildings Part 2: Application.” NICH Report No. CP-550-29693. Golden, CO.: National Renewable Energy Laboratory. Also published in the Journal of Solar Energy Engineering, ASME, Vol 124, No. 1, pp 17-21, 2002. http://www.nrel.gov/docs/fy01osti/29694.pdf. Accessed November 8, 2004.

DOE. (1995). U.S. Department of Energy, 1995. Code of Federal Regulations 10 - Energy. Washington, D.C.: Office of the Federal Register National Archives and Records Administration.

DOE. (2003). BTS Core Databook. Washington, DC: DOE Office of Building Technology, State and Community Programs.

EnergyPlus. (2004). EnergyPlus User's Manual, V1.2.1; October 2004. Engineering Document. Washington, DC: U.S. Department of Energy. http://www.energyplus.gov/. Accessed October 29, 2004.

Energy Simulation Specialists, Inc. (1995). DOE-2.lE Energy Simulation Seminar Workbook. Tempe, AZ: Energy Simulation Specialists, 1995.

Griffith, B.; Deru, M.; Torcellini, P. (2004). "Monitoring and Analysis of the Energy Performance of the Chesapeake Bay Foundation's Philip Merrill Environmental Center.” NREL/TP 550-34830. Golden, CO: National Renewable Energy Laboratory.

Hayter, S.; Torcellini, P.A.; Judkoff, R.; Jenior, M.M. (1998). Creating low-energy commercial buildings through effective design and evaluation. Proceedings of 1998 Summer Study on Energy Efficiency in Buildings. Washington, DC: American Council for an Energy-Efficient Economy. Also, Golden, CO: National Renewable Energy Laboratory, Report No. 24346.

Hayter, S., Torcellini, P.A.; Judkoff, R. (1999). “Optimizing building and HVAC systems.” ASHRAE Journal (41:12). Atlanta, GA: American Society of Heating, Refrigerating and Air-Conditioning Engineers (NREL Report No. 28212). 
Hayter, S.J.; Torcellini, P.A.; Judkoff, R.; Snead, R.C.; Hayter, R.B. (2000). Designing for Sustainability. CIBSE/ASHRAE Conference held September 20-22, 2000, in Dublin, Ireland. Atlanta, GA:

American Society of Heating, Refrigerating and Air-Conditioning Engineers. (NREL/CP-55027797).

Hygge, S.; Löfberg, H. (1999). Post Occupancy Evaluation of Daylight Buildings. Center for the Built Environment, Sweden, for IEA Solar and Heating Program Task 21 Subtask D.

Judkoff, R; Neymark, J. (1995). International Energy Agency Building Energy Simulation Test (BESTEST) and Diagnostic Method. Golden, CO.: National Renewable Energy Laboratory. pp. 300. NREL Report No. TP-472-6231.

Marion, W. (1995), Solar Radiation Data Manual for Buildings, Golden, CO: National Renewable Energy Laboratory, NREL Report TP-463-7904.

Miller, B. (May/June 1998), "Solar Researchers Walk-the-Talk." Solar Today. Boulder, CO: American Solar Energy Society (12:3), p. 44.

NREL. (1995). User's Manual for TMY2s (Typical Meteorological Years), NREL/SP-463-7668, and TMY2s, Typical Meteorological Years Derived from the 1961-1990 National Solar Radiation Data Base. Golden, CO: National Renewable Energy Laboratory. CD-ROM. http://rredc.nrel.gov/solar/old_data/nsrdb/tmy2. Accessed November 8, 2004.

NREL. (2004). Photographic Information eXchange (PIX). Golden, CO: National Renewable Energy Laboratory. http://www.nrel.gov/data/pix/. Accessed November 8, 2004.

Palmiter, L.; Wheeling, T.; Judkoff, R.; Wortman, D.; Simms, D.; O’Doherty, B. (1983). SERIRES-1.0. Solar Energy Research Institute Residential Energy Simulator, Version 1.0. Solar Energy Research Institute (now NREL), Golden, CO.

Pilkington. (2004). Pilkington Solar $\mathrm{E}^{\mathrm{TM}}$ Color-Neutral Solar Control Low-E Glass. http://www.pilkington.com/resources/solare.pdf. Accessed November 8, 2004. Toledo, OH: Pilkington.

SA. (1993). Specification Sheet for Stage II Indirect / Direct Evaporative Cooling Module. Canutillo, TX: SPEC-AIR.

Ternoey, S.; Bickle, L.; Robbins, C.; Busch, R.; McCord, K. (1985). The Design of Energy-responsive Commercial Buildings, New York, NY: John Wiley \& Sons, Inc.

Torcellini, P.; Judkoff, R.; and Crawley, D. (2004). "High-Performance Buildings: Lessons Learned." ASHRAE Journal. (46:9), pp. S4-S11. Atlanta, GA: American Society of Heating, Refrigerating, and Air-Conditioning Engineers.

VVI. (1995). Specification Sheet for HRV600i. Saskatoon, Saskatchewan, Canada: Venmar Ventilation Inc. (VVI).

Winkelmann, F.C.; Birdsall, B.E.; Buhl, W.F.; Ellington, K.L ; Erdem, A.E. ; Hirsch, J.J., Gates, S. (1993). DOE-2 BDL Summary Version 2.1E. LBNL-34946. Berkeley, CA: Lawrence Berkeley National Laboratory. 


\section{Appendix A. Design Team Contact List}

Information on this list was current at the time of construction.

Contracting Party:

Midwest Research Institute

National Renewable Energy Laboratory Division

Contractor:

J.C. Brooks and Company, Inc.

5195 West $58^{\text {th }}$ Avenue

Arvada, Colorado 80002

Architect:

James D. Copeland Architects, Inc.

Contact: James Copeland

Suite 301

207 Canyon Boulevard

Boulder, Colorado 80302

Phone: 303-443-4335

Fax: 303-444-5826

Building System Engineers:

Burns and McDonnell Engineers, Architects and Consultants

Contact: Charlie Fountain

8055 East Tufts Avenue

Denver, Colorado 80237

Phone: 303-721-9292

Fax: 303-721-0563

Building Control Systems:

Setpoint Systems Corporation

Contact: Aaron Nahale

2680 South Platte River Drive

Denver, Colorado 80223-4208

Phone: 303-733-2300

Conceptual Design:

LightForms

Contact: Steve Ternoey

2888 Bluff Street No. 323

Boulder, Colorado 80301

Energy Analysis:

National Renewable Energy Laboratory

Contact: Paul Torcellini and Ron Judkoff

1617 Cole Blvd.

Golden, CO 80401 


\section{Appendix B. Comfort Analysis}

Thermal Test Facility Comfort Analysis In accordance to ASHRAE Standard 55 - 1992

\begin{tabular}{l|c}
\multicolumn{2}{l}{ Perimeter Office Cubicle (Michael Ketcham) } \\
\multicolumn{1}{|l|}{ Date } & $9 / 8 / 98$ \\
Time & $12: 50$ inc DLST \\
Tdb(outdoor) & $83 \mathrm{Deg}$ \\
RH(outdoor) & $42.5 \%$ \\
RH(indoor) & $65 \%$ \\
Sky Cond. & Clear to Partly Cloudy \\
& \\
E-W Length Room & 9 \\
N-S Length of Room & 8.5 \\
Ceiling Height & 12
\end{tabular}

Operative Temperature Study and Radiant Temperature Asymmetry Study

Ts(North)

Ts(East)

Ts(South)
Ts(West)

Ts(Ceiling)

Ts(Floor)

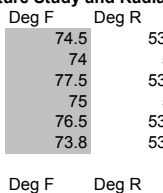

$\begin{array}{rr} & \mathrm{a}(\mathrm{ft}) \\ 534.5 & 4.5 \\ 534 & 4.25 \\ 537.5 & 4.5 \\ 535 & 4.25 \\ 536.5 & 4.25 \\ 533.8 & 4.25\end{array}$

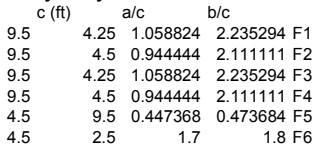

$\begin{array}{ccr}\text { Fig C1 - C4 } \# \text { of sections } & \text { Total F } & \\ 0.057 & 2 & 0.114 \\ 0.056 & 2 & 0.112 \\ 0.057 & 2 & 0.114 \\ 0.056 & 2 & 0.112 \\ 0.01 & 4 & 0.04 \\ 0.062 & 4 & 0.248\end{array}$

Ts(North)

Ts(East)

Ts(South)

Deg F ${ }_{74.5}$ Deg R 534.5 a (ft) 4.5 b (ft)

$\begin{array}{llll}\mathrm{C}(\mathrm{ft}) & & & \\ & 4.25 & 1.058824 & 0.588235 \mathrm{~F} 1\end{array}$

$\begin{array}{rrrrrrr}74.5 & 534.5 & 4.5 & 2.5 & 4.25 & 1.058824 & 0.588235 \text { F1 } \\ 74 & 534 & 4.25 & 2.5 & 4.5 & 0.944444 & 0.555556 \text { F2 }\end{array}$

$\begin{array}{rrrrrrr}74 & 534 & 4.25 & 2.5 & 4.5 & 0.944444 & 0.555556 \text { F2 } \\ 77.5 & 537.5 & 4.5 & 2.5 & 4.25 & 1.058824 & 0.588235 \text { F3 }\end{array}$

Ts(West)

$\begin{array}{llll}4.5 & 0.944444 & 0.555556 \mathrm{~F} 4\end{array}$

Ts(Ceiling) - Asym

$\begin{array}{lll}76.5 & 536.5 & 4.25 \\ 73.8 & 533.8 & 4.25\end{array}$

4.5
4.5

$\begin{array}{ll}6 & 0.708333 \\ 6 & 0.708333\end{array}$

$0.75 \mathrm{~F} 5$
$0.75 \mathrm{~F} 6$

$\begin{array}{lll} & \text { Deg } \mathrm{R} & \text { Deg } \mathrm{F} \\ \text { Trad,mean } & 534.9584 & 74.9584\end{array}$

Ta(24") $\quad 74.1$ Deg F

Va $\quad 0-15 \quad \mathrm{fpm}$

a

\begin{tabular}{ll|}
\hline Toperative & $74.5292 \mathrm{Deg} F$ \\
\hline
\end{tabular}

Assymetric Radiant Study

East-West

$\begin{array}{ll}\text { North-South } & 0.34 \mathrm{Deg} F \\ \text { F } & 0.11 \mathrm{Deg} F\end{array}$

Floor-Ceiling $\quad 0.39 \mathrm{Deg} F$

Maximum Building Drift Study Max. Drift

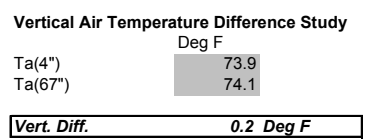

Floor Temperature Study

\begin{tabular}{ll|}
\hline Floor Temp. & $73.8 \mathrm{Deg} F$ \\
\hline
\end{tabular}

\section{Air Speed Study}

At Foot Level

$\mathrm{Ta}$
$\mathrm{Tu}$

Va

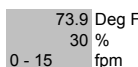

HVAC Information

Air Supply Rate

Room / Supply Temp. / Diff.

Type / Location Diffus

Discharge Velocity

Per. Heat Type / Loc./ Status

Return Grille Loc. / Size
$74.1 / 63.8 / 10.3 \quad 2000 \mathrm{cfm}$

North end of zone, vertical, near ceiling

$1650 \mathrm{fpm}$

None

VAV, ID Evap, FPMC 
Thermal Test Facility Comfort Analysis

In accordance to ASHRAE Standard 55 - 1992

Interior Office Cubicle (Next to Michael Ketcham)

9/8/98 $13: 00$ inc DLST

$\mathrm{Tdb}$ (outdoor)

$\mathrm{RH}$ (outdoor)

Sky Cond.

83 Deg

$56 \%$

Clear to Partly Cloudy

E-W Length Room

$\mathrm{N}$-S Length of
Ceiling Height

Operative Temperature Study and Radiant Temperature Asymmetry Study

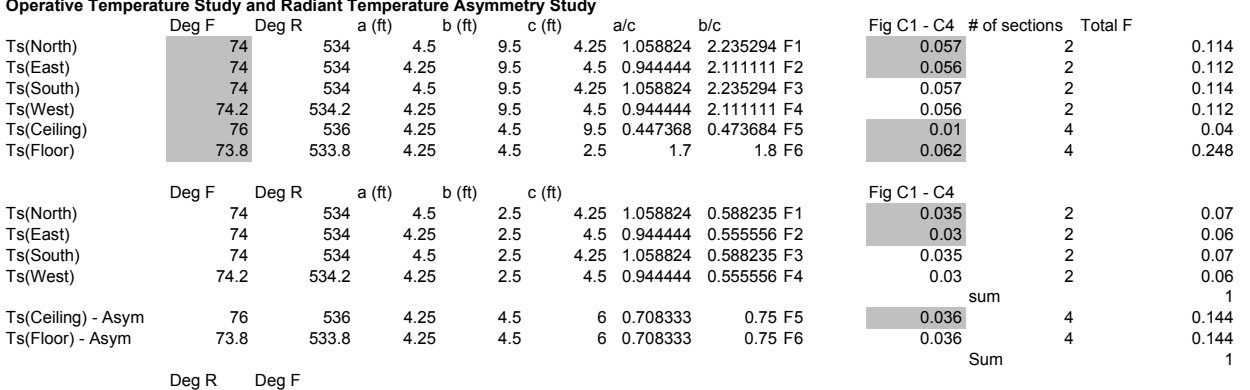

$\begin{array}{lcc} & \text { Deg } R & \text { Deg F } \\ \text { Trad,mean } & 534.0648 & 74.0648\end{array}$

Ta(24") 74.5 Deg F

Va $30 \mathrm{fpm}$

a

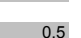

\begin{tabular}{ll}
\hline Toperative & \\
\hline
\end{tabular}

Assymetric Radiant Study \begin{tabular}{|ll}
\hline East-West & $0.00 \mathrm{Deg} F$ \\
North-South & $0.02 \mathrm{Deg} F$
\end{tabular} $\begin{array}{ll}\text { North-South } & 0.02 \mathrm{Deg} F \\ \text { Floor-Ceiling } & 0.32 \mathrm{Deg} F\end{array}$

\section{Maximum Building Drift Study
\begin{tabular}{|l}
\hline Max. Drift $0.7 \mathrm{Deg} F / \mathrm{hr}$ \\
\hline
\end{tabular}}

Vertical Air Temperature Difference Study

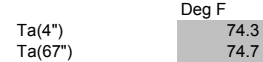

$\mathrm{Ta}\left(67^{\prime \prime}\right)$

$0.4 \operatorname{Deg} F$

Floor Temperature Study Floor Temp.

Air Speed Study

At Foot Leve

$\mathrm{Ta}$
$\mathrm{Tu}$

$\mathrm{Va}$

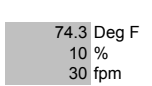

HVAC Information

Air Supply Rate

74.7/63.8/10 $2000 \mathrm{cfm}$

Type / Lopption Diffuser

Discharge Velocity

Per. Heat Type / Loc. / Status

Return Grille Loc. / Size

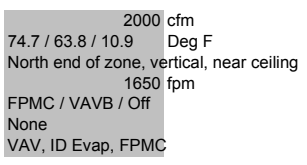

None 
Thermal Test Facility Comfort Analysis

In accordance to ASHRAE Standard 55 - 1992

Mid-bay Laboratory Area

Date

$\begin{array}{ll}\text { Time } & \text { 9/8/98 } \\ \text { Time DLST }\end{array}$

\begin{tabular}{l|l} 
Tdb(outdoor) & $83.6 \mathrm{Deg}$ \\
$\mathrm{RH}$ (outdoor) & $40 \%$
\end{tabular}

$\begin{array}{ll}\mathrm{RH} \text { (outdoor) } & 40 \% \\ \mathrm{RH} \text { (indoor) } & 56 \%\end{array}$

RH(indoor)
Sky Cond. Clear to Partly Cloudy

\begin{tabular}{|l|l|}
\hline E-W Length Room & 50 \\
N-S Length of Room & 30 \\
Ceiling Height & 18 \\
\hline
\end{tabular}

Operative Temperature Study and Radiant Temperature Asymmetry Study

Ts(North)
Ts(East)

Ts(East)
Ts(South)

Ts(West)

Ts(Ceiling)

Deg F $77.2{ }_{537.2}^{a}$

\begin{tabular}{|l|l|}
77.2 & 537.2 \\
76.2 & 536.2 \\
76.8 & 536.8 \\
76.4 & 536.4 \\
81.5 & 541.5 \\
74.8 & 534.8 \\
\hline
\end{tabular}

fft) $\mathrm{b}(\mathrm{ft})$
25
15
25
15
15
15

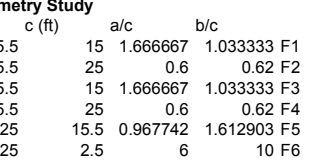

Fig C1 - C4 \# of sections Total F

$\begin{array}{rrr}-0.05 & 2 & 0.1 \\ 0.021 & 2 & 0.042 \\ 0.05 & 2 & 0.1 \\ 0.021 & 2 & 0.042 \\ 0.049 & 4 & 0.196 \\ 0.11 & 4 & 0.44\end{array}$

Ts(North)

Ts(East)

Ts(South)
Ts(West)

$\begin{array}{cc}\text { Deg F } & \text { Deg R } \\ 77.2 & 537.2 \text { (ft) } \\ 76.2 & 536.2 \\ 76.8 & 536.8 \\ 76.4 & 536.4 \\ & \\ 81.5 & 541.5\end{array}$

$25^{\mathrm{b}(\mathrm{ft})} 2.5^{\mathrm{c}(\mathrm{ft})}$

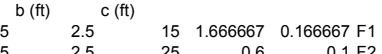

$\begin{array}{rrr}15 & 1.666667 & 0.166667 \mathrm{~F} 1 \\ 25 & 0.6 & 0.1 \mathrm{~F} 2 \\ 15 & 1.666667 & 0.166667 \mathrm{~F} 3\end{array}$

Fig C1 - C4

Ts(West)

Ts(Ceiling) - Asym
Ts(Floor) - Asym

$\begin{array}{ll}81.5 & 541.5 \\ 74.8 & 534.8\end{array}$

$\begin{array}{rrr} & 0.6 & 0.1 \mathrm{~F} 4 \\ 9 & 1.666667 & 2.777778 \mathrm{~F} 5\end{array}$

$\begin{array}{lll}1.666667 & 2.777778 \text { F6 }\end{array}$

$\begin{array}{lll} & \text { Deg } \mathrm{R} & \text { Deg F } \\ \text { Trad,mean } & 536.8272 & 76.8272\end{array}$

Ta(24") $\quad 75.2$ Deg F

Va $17 \mathrm{fpm}$

a

Toperative $\quad 76.0136 \mathrm{DegF}$

Assymetric Radiant Study

East-West

Floor-Ceiling $\quad 2.13 \mathrm{Deg} F$

\section{Maximum Building Drift Study}

$0.6 \mathrm{Deg} F / \mathrm{hr}$

Vertical Air Temperature Difference Study

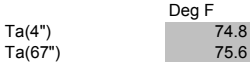

$\mathrm{Ta}(67 ")$

\section{\begin{tabular}{ll}
\hline Vert. Diff. & $0.8 \mathrm{Deg} F$ \\
\hline
\end{tabular}}

Floor Temperature Study Floor Temp.

74.8 Deg F

Air Speed Study

At Foot Level

$\mathrm{Tu}$
$\mathrm{Va}$

$\begin{array}{r}74.8 \\ 10 \\ 10\end{array}$
$0-15 \quad$ peg F
fpm

HVAC Informatio

Air Supply Rate

Room / Supply Temp / Diff- $\quad 753 / 63.62500$ cfm

Type / Location Diffuser

Per. Heat Type / Loc. / Status

Per. Heat Type / Loc./Sta

Return Grille Loc. I Size

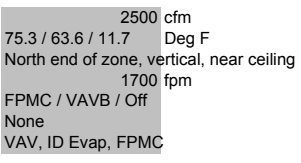

VAV, ID Evap, FPMC 
Thermal Test Facility Comfort Analysis

In accordance to ASHRAE Standard 55 - 1992

High-bay Laboratory Area

$\begin{array}{ll}\text { 9/8/98 } & \text { 14:05 inc DLST } \\ \text { Time } & \end{array}$

\begin{tabular}{l|l} 
Tdb(outdoor) & $83.5 \mathrm{Deg}$ \\
$\mathrm{RH}$ (outdoor) & $40 \%$
\end{tabular}

$\begin{array}{ll}\mathrm{RH} \text { (outdoor) } & 40 \% \\ \mathrm{RH} \text { (indoor) } & 56 \%\end{array}$

RH(indoor) $\quad$ Clear to Partly Cloudy
Sky Cond.

\begin{tabular}{|l|l|}
\hline E-W Length Room & 78 \\
N-S Length of Room & 35 \\
Ceiling Height & 24 \\
\hline
\end{tabular}

Operative Temperature Study and Radiant Temperature Asymmetry Study

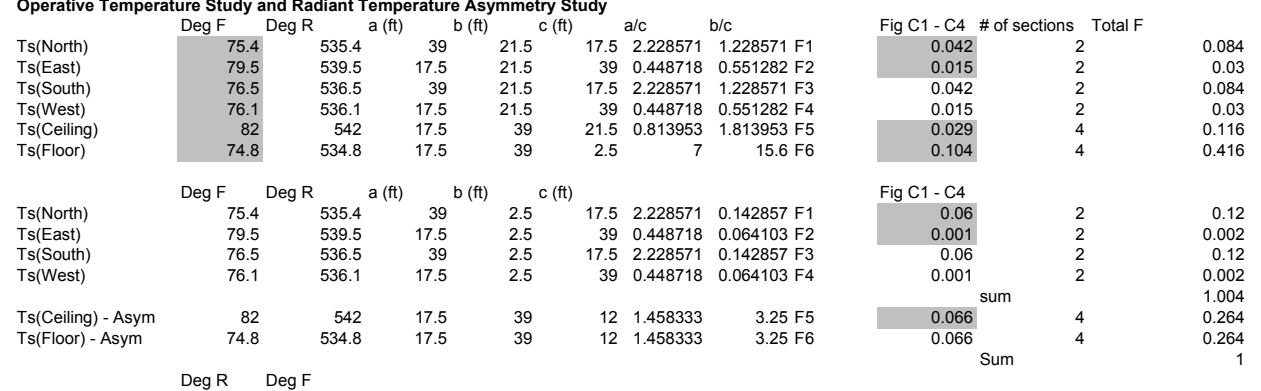

$\begin{array}{ccc} & \text { Deg } R & \text { Deg F } \\ \text { Trad,mean } & 538.4356 & 78.4356\end{array}$

$\mathrm{Ta}(24 ") \quad 75.5 \mathrm{Deg} F$

\begin{tabular}{ll}
$\mathrm{Va}$ & $25 \mathrm{fpm}$ \\
\hline
\end{tabular}

a

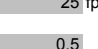

Toperative $\quad 76.9678$ Deg F

Assymetric Radiant Study

\begin{tabular}{|ll}
\hline East-West & $0.09 \mathrm{Deg} F$ \\
North-South & $0.10 \mathrm{Deg}$
\end{tabular}

$\begin{array}{ll}\text { North-South } & 0.10 \mathrm{Deg} F \\ \text { Floor-Ceiling } & 1.90 \mathrm{Deg} F\end{array}$

Maximum Building Drift Study

Max. Drift $0.6 \mathrm{Deg} F / \mathrm{hr}$

Vertical Air Temperature Difference Study

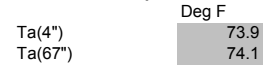

74.1

Vert. Diff. $0.2 \mathrm{Deg} F$

HVAC Information

Air Supply Rate

Room / Supply Temp. / Diff.

Type / Location Diffuser

Der. Heat Type / Loc. / Status

Return Grille Loc. / Size

Type of HVAC
$4000 \mathrm{cfm}$
$75.5 / 63.6 / 11.9 \quad$ Deg F

South-central location, vertical, mid-bay ceiling height

$1700 \mathrm{fpm}$
FPMC / VAVB / Off

None

VAV, ID Evap, FPMC

Floor Temperature Study
\begin{tabular}{|l|l|}
\hline Floor Temp. & 74.8 Deg F \\
\hline
\end{tabular}

Air Speed Study

At Foot Level

$\mathrm{Ta}$
$\mathrm{Tu}$

$\mathrm{Tu}$
$\mathrm{Va}$

75.2 Deg F
$20 \%$
$42 \mathrm{fpm}$

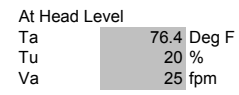


Thermal Test Facility Comfort Analysis

In accordance to ASHRAE Standard 55 - 1992

Conference Room

Date

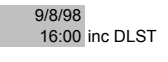

Tdb(outdoor)

RH(outdoor)

Sky Cond.

85.6 Deg

$50 \%$

Clear to Partly Cloudy

$\begin{array}{lr}\text { E-W Length Room } & 29.5 \\ \text { N-S Length of Room } & 15.5\end{array}$

Ceiling Height

Operative Temperature Study and Radiant Temperature Asymmetry Study

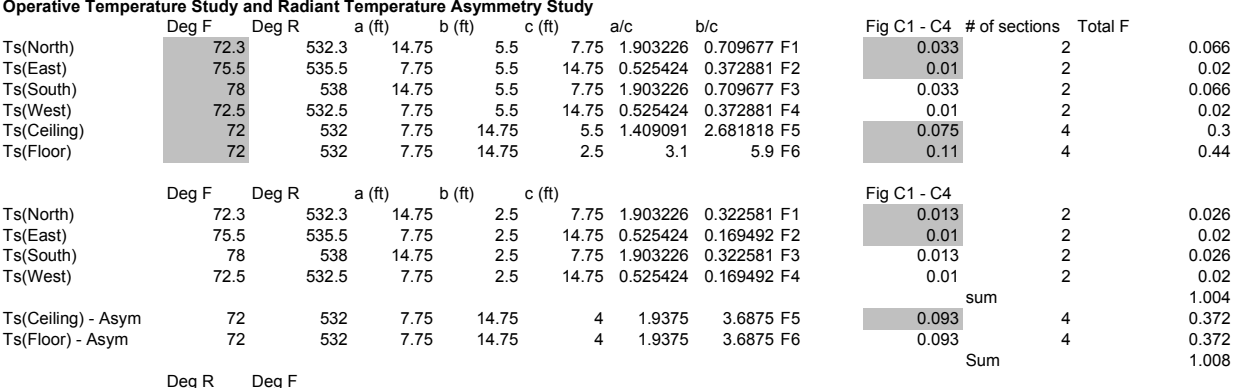

$\begin{array}{ccc} & \text { Deg } R & \text { Deg F } \\ \text { Trad,mean } & 534.8676 & 74.8676\end{array}$

Ta(24") 73 Deg F

Va $45 \mathrm{fpm}$

a

Toperative $\quad 73.74704$ Deg F

Assymetric Radiant Study

\begin{tabular}{|ll|}
\hline East-West & $0.38 \mathrm{Deg} F$ \\
North-South & $0.06 \mathrm{Deg}$
\end{tabular}

$\begin{array}{ll}\text { North-South } & 0.06 \mathrm{Deg} F \\ \text { Floor-Ceiling } & 0.00 \mathrm{Deg} F\end{array}$

Maximum Building Drift Study

Max. Drift $3.7 \mathrm{Deg} F / \mathrm{hr}$

Vertical Air Temperature Difference Study

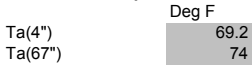

\begin{tabular}{ll}
\hline Vert. Diff. & $4.8 \mathrm{Deg} F$ \\
\hline
\end{tabular}

Floor Temperature Study

\begin{tabular}{l} 
Floor Temperature Study \\
\hline Floor Temp. \\
\hline
\end{tabular}

Air Speed Study

At Foot Level

$\mathrm{Ta}$

Tu

$69.2 \mathrm{Deg} F$
$50 \%$
$40 \mathrm{fpm}$

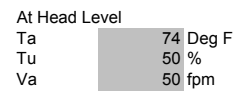

HVAC Informatio

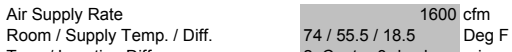

Type / Location Diffuse

Discharge Velocity
Per. Heat Type / Loc. / Status

Return Grille Loc. / Size

Type of HVAC
$74 / 55.5 / 18.5$ Deg F

$1650 \mathrm{fpm}$

列

Pack RT A/C w HC 


\section{Appendix C. TTF Cost Information}

Table C-1 Breakdown of TTF Construction Costs

\begin{tabular}{|l|c|}
\hline \multicolumn{1}{|c|}{ Description of Work } & $\begin{array}{c}\text { Cost (1995 } \\
\text { Dollars) }\end{array}$ \\
\hline \hline General Requirements & $\$ 29,292$ \\
\hline Excavation, Backfill & 61,648 \\
\hline Drilled Piers & 20,596 \\
\hline Bituminous Paving & 6,414 \\
\hline Concrete Paving Exterior & 33,766 \\
\hline Service Water/Sever & 40,810 \\
\hline Landscaping & 26,098 \\
\hline Concrete Cast-in-place & 42,757 \\
\hline Concrete Flatwork Interior & 13,200 \\
\hline Tilt-up Concrete & 46,273 \\
\hline Structural Steel & 68,200 \\
\hline Joists and Deck & 33,322 \\
\hline Cold Formed Metal Framing & 15,477 \\
\hline Metal Fabrications & 48,500 \\
\hline Wood and Plastics & 9,262 \\
\hline Water/Damp Proofing/FS & 17,203 \\
\hline Building Insulation & 5,130 \\
\hline EIFS & 51,090 \\
\hline Roofing and Sheet Metal & 48,569 \\
\hline Doors and Frames & 6,782 \\
\hline Overhead Doors & 6,340 \\
\hline Alum Storefront/Glass/WW & 30,261 \\
\hline Finish Hardware/Operators & 4,770 \\
\hline Gypsum Board System & 50,500 \\
\hline Tile/SAC/VCT/Carpet & 17,226 \\
\hline Painting & 19,688 \\
\hline Specialties & 3,347 \\
\hline Fire Protection & 12,850 \\
\hline Plumbing & 57,017 \\
\hline HVAC & 127,300 \\
\hline Temperature Controls & 65,447 \\
\hline Electrical & 50,450 \\
\hline Switch Gear & 14,900 \\
\hline Lighting & 9,500 \\
\hline Lightning Protection & 3,650 \\
\hline Fire Alarm System & \\
\hline Security System & \\
\hline
\end{tabular}




\begin{tabular}{|l|c|}
\hline \multicolumn{1}{|c|}{ Description of Work } & $\begin{array}{c}\text { Cost (1995 } \\
\text { Dollars) }\end{array}$ \\
\hline Mod\#1 & 22,600 \\
\hline Mod\#2/Mega Lugs/Glass & 3,577 \\
\hline Mod\#3/K Bracing/Window & 1,324 \\
\hline Mod\#4 & 33,151 \\
\hline Total Cost \$ & $\mathbf{\$ 1 , 1 8 7 , 2 8 7}$ \\
\hline
\end{tabular}


Appendix D. Change Orders

Table D-1 Breakdown of Change Orders during Construction

\begin{tabular}{|l|r|}
\hline \multicolumn{1}{|c|}{ Description of Change Order } & Cost \\
\hline 1. Additional parking lot work (demolition and re-paving) & $\$ 22,600$ \\
\hline 2. South facing ground windows to low-e glass & 1,481 \\
\hline 3. Change all clerestories to low-e glass & 1,396 \\
\hline 4. Install "Mega Lugs" and encase in concrete where sewer crosses water & 700 \\
\hline 5. Change "X" bracing to "K" bracing for ductwork & 900 \\
\hline 6. Change window design to 72 x 42 for louvers & 424 \\
\hline 7. Add roof mounted array rack & 9,177 \\
\hline 8. Additional dry wall work @ columns and ceiling & 1,742 \\
\hline 9. Break-up concrete slab & 437 \\
\hline 10. Move and install freeze protected hydrant & 1,372 \\
\hline 11. Credit - Move and install freeze protected hydrant & $-1,694$ \\
\hline 12. Install 3, 8-ft deep, caissons & 1,200 \\
\hline 13. Install KTZ meter option & 182 \\
\hline 14. Move fans in high-bay - North 6 ft & 990 \\
\hline 15. Install light fixtures below duct & 492 \\
\hline 16. 24 feet of 12"CMP @ west parking area & 528 \\
\hline 17. Remove concrete vault & 960 \\
\hline 18. Re-hang duct in mid-bay area & 1,037 \\
\hline 19. Update fire protection from light hazard to ordinary hazard & 5,072 \\
\hline 20. Replace asphalt at DWP and west of FTLB & 7,089 \\
\hline 21. Install 3" butterfly valves on chiller water line & 658 \\
\hline 22. Add 4 " wire to six fans to allow reverse motion & 1,350 \\
\hline 23. Credit for missing reinforced steel & -450 \\
\hline 24. Add 2" PVC pipes at roof penetration & 200 \\
\hline 25. Change EF-1 480v fan motor to 120v & 584 \\
\hline 26. Raise manholes & 770 \\
\hline 27. Additional concrete work (curb and gutter) & 1,455 \\
\hline & $\$ 60,652$ \\
\hline Total Change Orders & \\
\hline
\end{tabular}




\section{Appendix E. Cost Estimate Comparison by Independent Estimator}

NREL retained an independent estimator to determine TTF construction costs for three additional scenarios. These numbers can be compared to the TTF as-built scenario. The value of this analysis is extending the TTF outside the government sector and constructing the building for the commercial sector. In the commercial sector, the TTF could be adapted for a small office building, light manufacturing, warehousing, and retail. Table E-1 shows these costs in 1995 dollars.

Table E-1 Breakdown of Costs for Different Scenarios by an Independent Estimator

\begin{tabular}{|c|c|c|c|c|}
\hline & $\begin{array}{c}\text { NREL Budget } \\
\text { Cost }\end{array}$ & TTF As-Built & $\begin{array}{c}\text { TTF in } \\
\text { Commercial } \\
\text { Sector }\end{array}$ & \begin{tabular}{|c|} 
TTF in \\
Commercial \\
Sector w/o \\
Windows
\end{tabular} \\
\hline General Conditions & $\$ 29,292$ & $\$ 169,470$ & $\$ 128,761$ & $\$ 128,458$ \\
\hline Site Work & $\$ 134,970$ & $\$ 100,251$ & $\$ 92,150$ & $\$ 95,955$ \\
\hline Concrete & $\$ 156,565$ & $\$ 176,774$ & $\$ 174,141$ & $\$ 174,141$ \\
\hline Masonry & & $\$ 0$ & $\$ 0$ & $\$ 0$ \\
\hline Metals & $\$ 150,022$ & $\$ 127,500$ & $\$ 120,000$ & $\$ 90,000$ \\
\hline Wood and Plastics & $\$ 9,262$ & $\$ 24,750$ & $\$ 24,750$ & $\$ 18,750$ \\
\hline $\begin{array}{l}\text { Thermal and } \\
\text { Moisture Prot }\end{array}$ & $\$ 70,902$ & $\$ 37,900$ & $\$ 37,000$ & $\$ 34,810$ \\
\hline Doors and Windows & $\$ 48,153$ & $\$ 41,150$ & $\$ 41,150$ & $\$ 15,450$ \\
\hline Finishes & $\$ 153,981$ & $\$ 127,601$ & $\$ 119,951$ & $\$ 127,361$ \\
\hline Specialties & $\$ 3,347$ & $\$ 5,150$ & $\$ 5,150$ & $\$ 5,150$ \\
\hline Equipment & & $\$ 0$ & $\$ 0$ & $\$ 0$ \\
\hline Furnishings & & $\$ 6,500$ & $\$ 3,500$ & $\$ 1,500$ \\
\hline Special Construction & & $\$ 0$ & $\$ 0$ & $\$ 0$ \\
\hline Conveying Systems & & $\$ 0$ & $\$ 0$ & $\$ 0$ \\
\hline Mechanical & $\$ 197,167$ & $\$ 122,060$ & $\$ 112,060$ & $\$ 112,060$ \\
\hline Electrical & $\$ 172,947$ & $\$ 143,500$ & $\$ 126,000$ & $\$ 126,000$ \\
\hline Subtotal & $\$ 1,126,608$ & $\$ 1,082,606$ & $\$ 984,613$ & $\$ 929,635$ \\
\hline Contractors Fee & & $\$ 0$ & $\$ 0$ & $\$ 0$ \\
\hline Contingency & $\$ 0$ & $\$ 0$ & $\$ 0$ & $\$ 0$ \\
\hline Bond Cost & $\$ 0$ & $\$ 0$ & $\$ 0$ & $\$ 0$ \\
\hline Grand Total & $\$ 1,126,608$ & $\$ 1,082,606$ & $\$ 984,613$ & $\$ 929,635$ \\
\hline Building Area $\left(\mathrm{ft}^{2}\right)$ & 10,000 & 10,000 & 10,608 & 10,608 \\
\hline$\$ / \mathrm{ft}^{2}$ & $\$ 112.66$ & $\$ 108.26$ & $\$ 92.19$ & $\$ 87.63$ \\
\hline
\end{tabular}


Table E-2 Details of Cost Comparison

\begin{tabular}{|c|c|c|c|}
\hline General Conditions & $\begin{array}{c}\text { TTF As-Built at } \\
\text { NREL }\end{array}$ & $\begin{array}{c}\text { TTF as } \\
\text { Commercial }\end{array}$ & $\begin{array}{l}\text { TTF w/o } \\
\text { Windows }\end{array}$ \\
\hline Blueprints & $\$ 475$ & $\$ 475$ & $\$ 475$ \\
\hline Project Management & $\$ 38,016$ & $\$ 31,104$ & $\$ 31,104$ \\
\hline Supervision & $\$ 76,032$ & $\$ 62,208$ & $\$ 62,208$ \\
\hline Construction Office & $\$ 3,250$ & $\$ 2,600$ & $\$ 2,600$ \\
\hline Sanitary Facilities & $\$ 8,052$ & $\$ 6,588$ & $\$ 6,588$ \\
\hline Trash Service & $\$ 8,174$ & $\$ 6,539$ & $\$ 6,539$ \\
\hline Temp Power & $\$ 2,520$ & $\$ 2,016$ & $\$ 2,016$ \\
\hline Temp Phone & $\$ 1,250$ & $\$ 1,000$ & $\$ 1,000$ \\
\hline Temp Heat & $\$ 1,620$ & & \\
\hline Temp Fence & $\$ 5,625$ & $\$ 5,625$ & $\$ 5,625$ \\
\hline Temp Water & $\$ 1,250$ & $\$ 1,000$ & $\$ 1,000$ \\
\hline Winter Protection & $\$ 5,932$ & & \\
\hline Job Safety & $\$ 4,752$ & $\$ 3,888$ & $\$ 3,888$ \\
\hline Progress Cleaning & $\$ 9,504$ & $\$ 2,700$ & $\$ 2,700$ \\
\hline Final Cleaning & $\$ 1,320$ & $\$ 1,320$ & $\$ 1,320$ \\
\hline Punch List & $\$ 1,698$ & $\$ 1,698$ & $\$ 1,395$ \\
\hline Saw Cutting & $\$ 4,296$ & & \\
\hline Clearing and Grubbing & $\$ 7,500$ & $\$ 7,500$ & $\$ 7,500$ \\
\hline Earthwork & $\$ 16,650$ & $\$ 16,650$ & $\$ 16,650$ \\
\hline Asphalt Paving & $\$ 22,000$ & $\$ 22,000$ & $\$ 22,000$ \\
\hline Stripping And Bumpers & $\$ 1,500$ & $\$ 1,500$ & $\$ 1,500$ \\
\hline Curb And Gutter & $\$ 9,500$ & $\$ 9,500$ & $\$ 9,500$ \\
\hline Landscaping & $\$ 38,805$ & $\$ 35,000$ & $\$ 38,805$ \\
\hline Material & $\$ 87,560$ & $\$ 90,738$ & $\$ 90,738$ \\
\hline Interior Slab on Grade & $\$ 14,159$ & $\$ 14,159$ & $\$ 14,159$ \\
\hline Exterior Slab on Grade & $\$ 6,361$ & $\$ 6,361$ & $\$ 6,361$ \\
\hline Caissons & $\$ 3,765$ & & \\
\hline Cast-in-place & $\$ 341$ & & \\
\hline Grade Beams and Walls & $\$ 25,464$ & $\$ 6,219$ & $\$ 6,219$ \\
\hline Cast Above Grade & $\$ 2,748$ & $\$ 2,749$ & $\$ 2,749$ \\
\hline Reinforcing & $\$ 15,000$ & $\$ 15,000$ & $\$ 15,000$ \\
\hline Tilt-up & $\$ 18,676$ & $\$ 36,215$ & $\$ 36,215$ \\
\hline Pumping & $\$ 1,200$ & $\$ 1,200$ & $\$ 1,200$ \\
\hline Ceramic Tile & $\$ 5,500$ & $\$ 5,500$ & $\$ 5,500$ \\
\hline Resilient Flooring & $\$ 4,410$ & $\$ 4,410$ & $\$ 4,410$ \\
\hline Top Set Base & $\$ 1,100$ & $\$ 1,100$ & $\$ 1,100$ \\
\hline Carpeting & $\$ 4,351$ & $\$ 4,351$ & $\$ 4,351$ \\
\hline Painting & $\$ 15,000$ & $\$ 15,000$ & $\$ 15,000$ \\
\hline
\end{tabular}




\begin{tabular}{|l|r|r|r|}
\hline \multicolumn{1}{|c|}{ General Conditions } & $\begin{array}{c}\text { TTF As-Built at } \\
\text { NREL }\end{array}$ & $\begin{array}{c}\text { TTF as } \\
\text { Commercial }\end{array}$ & $\begin{array}{c}\text { TTF w/o } \\
\text { Windows }\end{array}$ \\
\hline Toilet Partitions & $\$ 1,700$ & $\$ 1,700$ & $\$ 1,700$ \\
\hline Signs and Graphics & $\$ 2,500$ & $\$ 2,500$ & $\$ 2,500$ \\
\hline Toilet and Bath Acc. & $\$ 950$ & $\$ 950$ & $\$ 950$ \\
\hline Window Treatment & $\$ 6,500$ & $\$ 3,500$ & $\$ 1,500$ \\
\hline MECHANICAL & & & $\$ 25,000$ \\
\hline Plumbing & $\$ 35,000$ & $\$ 25,000$ & $\$ 10,000$ \\
\hline Evaporative Coolers & $\$ 10,000$ & $\$ 10,000$ & $\$ 12,060$ \\
\hline Fire sprinklers & $\$ 12,060$ & $\$ 12,060$ & $\$ 65,000$ \\
\hline HVAC & $\$ 65,000$ & $\$ 65,000$ & \\
\hline ELECTRICAL & & & $\$ 126,000$ \\
\hline General Building & $\$ 143,500$ & $\$ 126,000$ & \\
\hline & & & $\$ 929,635$ \\
\hline GRAND TOTAL & $\$ 1,082,606$ & $\$ 984,613$ & \\
\hline & & & $\$ 87.64$ \\
\hline \$ $\mathrm{ft}^{2}$ & $\$ 108.26$ & & \\
\hline
\end{tabular}

\section{Letter from Karl Meader}

\section{NREL TTF FACILITY \\ GOLDEN, COLORADO}

\section{Mr. Stefan Craine:}

This building as built is a typical institutional building, constructed at NREL's Golden, Colorado site. It is located on a sloping site and retains almost 12 foot of soil along the entire north wall of the building and loading dock area. It is founded on caissons and grade beams. The slab is a typical slab on grade type of construction with wire mesh reinforcing. It is 4-in. thick in the office area and 6-in. thick in the work/warehouse area. The building shell is a composite structure with tilt-up concrete walls at the north wall for retaining purposes, and steel frame, steel stud, and synthetic plaster finish at the remainder of the structure. The roof is a steel beam, steel joist, and steel deck covered with rigid insulation, and a singleply elastomeric roof membrane. Interior partitions are both bearing and non-bearing steel stud and drywall construction. All interior exposed surfaces are painted including the roof structure. There is less than the average amount of interior walls. Interior finishes are typical institutional grade materials but not extravagant.

The actual budget of this building was $\$ 1,126,655$. A verification estimate made with out benefit of any prior knowledge of the actual cost came in at $\$ 1,082,606$. The cost of this project was $\$ 110$ dollars per square foot and is in line with current high-end institutional work.

The commercial estimate was based on the same size building constructed on a flat lot sized to provide the code-required parking and landscaping as required in the Denver area. Bid assumes that all utilities are stubbed into the property and that no major public right-of-way work will be required.

The building is figured as a concrete tilt-up structure with steel framing to support the roof and clerestory windows. Essentially the same roof structure is figured. Floor slabs are figured to be 4 in. throughout. All interior finishes are figured to be commercial grade office finishes with carpet in the office areas, VCT in lunch rooms, and tile floors and wainscot in the restrooms. 
The commercial building was figured as bearing wall construction founded on continuous footings. No allowance was assumed for unsuitable geological conditions.

The commercial estimate for this building puts the cost at $\$ 984,613$, which is about $\$ 92$ per square foot. This agrees closely with actual cost associated with building of this type and complexity.

It is my opinion that with some very careful planning this building could be constructed utilizing the energy saving features of the NREL TTF facility for this amount or less. Currently in Colorado, we are building schools for $\$ 94$ per square foot on 55,000 square feet, supermarkets for $\$ 60$ to $\$ 80$ dollars per square foot and commercial office/warehouse facilities for $\$ 50$ to $\$ 60$ per square foot.

The cost savings anticipated in the commercial building are caused by a slightly shortened schedule (36 versus 44 weeks) a simplified foundation system, less extensive use of aesthetic detailing on the exterior building, reduced electrical cost resulting from use of more competitive fixtures and equipment, and of course the savings realized by eliminating the extensive paperwork and reporting requirements of a Federal Government project.

Newstrom Davis, Construction

511 Orchard Street

Golden, CO 80401

(303) 216-2710 


\section{Appendix F. Comments from TTF Occupant Survey}

Occupants' comments from the TTF occupant survey are provided below. The survey results may be skewed because the building occupants are engaged in energy efficiency research. They are likely to be predisposed to be favorable to new energy technologies; however, they also tend to be critical of the technologies. There is also the potential that occupants will react to issues unrelated to the special energy features of the building (e.g., noisy lab work, low occupancy rates, quiet fans, etc.). This information should be noted when reviewing the comments below.

Question: Is there anything you particularly like about the TTF?

- "Natural daylight is easier on the eyes than fluorescents"

- "The open space, daylighting, energy efficiency (no refrigeration, passive solar)"

- "I like the fact that so much effort was put into it to make it such an energy-efficient building"

- "There is not many people in the building most of the time. A good view"

- "The daylight design"

- "No fan noise"

- "It has a good working atmosphere; it's open and bright. I like the tall ceilings and the fact that the whole building is bright not like traditional offices which have dark spaces."

- "Daylighting features: excellent light source views outside. All the energy saving features; occupancy sensors are well tuned. Evaporative system supplies abundant clean, comfortable air. Building overhangs keep summer sun off my desk, let me stay cool in the summer, warm in the winter. Mid- and high-bays allow for great possibilities of experiment setup."

- "Natural lighting makes easier working conditions on the eyes"

- "The lighting is very good. The automatic lighting is a good addition"

- "I like the efficiency of the building and how the lights turn off when they aren't needed"

- "Automatic controls (lights, etc.). Good light and energy control."

Question: Is there anything you particularly dislike about the TTF?

- "Need to install dimmable ballasts"

- "Flickering lights typical in morning and evening or when cloudy. I have no control"

- "While I worked there, the lights were not working properly. At my station, I felt that there were not enough foot-candles to perform my everyday tasks when the lights were off"

- "Stepped lighting controls are annoying. People working in the lab make a lot of racket"

- "Lighting and space conditioning systems don’t work well"

- "Inadequate parking. Ceiling fans are annoying and uncomfortable and waste energy in all seasons. Lighting controls turn on electric lights too much. I can't control electric lighting in my space except by removing lamps. HVAC air distribution velocities are annoying."

- "Glare from direct beam reflecting off center wall into interior cubes - rearranging cube configuration would solve this problem" 
- "Don't like cycling of lights in office area. I think that it has gotten better in the past few months. I don't mind it so much in the mid- and high-bay areas. No other complaints. Suggestion: dimmable ballasts in office areas"

- "Glare on the computer screens (all locations); dimmable ballasts would help extreme jump in lighting."

Question: Further Comments about the Building?

- "The ventilation fans were very noisy at times"

- "The most annoying thing about the building is the cold draft that blows through the cube and the lights switching on and off in a non-luminous manner. Currently I am the only person in my cube and the privacy is pleasant and allows me to work more effectively"

- "Noise can be a problem in the TTF. It would be nice to have a surface material that absorbed noise and reflected light. Glare off center wall into interior cubes is a problem in the spring seasons and winter. I didn't see a glare problem other times of the year."

- "It's an excellent place to work. I wouldn't want to be in a "typical" office building of any kind after working here. Environmental factors such as room temperature, drafts, and air quality are very good. Some times a bit noisy from the lab space."

- "The color of the inside walls is good. It brightens up the place."

- "I think the building is well designed and I have really enjoyed working in here"

- "Biggest problem with environmental controls are: (1) Desiccant experiment in high-bay dumps heat and humidity into the building (2) A/C not working right until recently (3) lighting only on/off and too dark before turns lights on." 


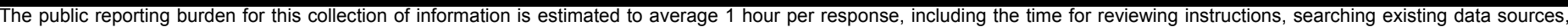

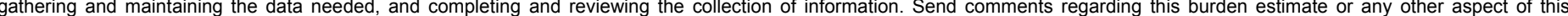

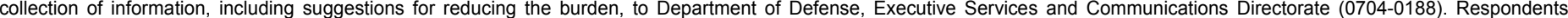

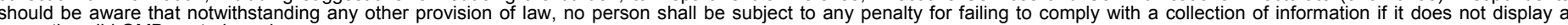
currently valid OMB control number.

PLEASE DO NOT RETURN YOUR FORM TO THE ABOVE ORGANIZATION.

\section{REPORT DATE (DD-MM-YYYY) February 2005}

4. TITLE AND SUBTITLE

Evaluation of the Energy Performance and Design Process of the

Thermal Test Facility at the National Renewable Energy Laboratory

6. AUTHOR(S)

P. Torcellini, S. Pless, B. Griffith, and R. Judkoff
3. DATES COVERED (From - To)

5a. CONTRACT NUMBER

DE-AC36-99-GO10337

5b. GRANT NUMBER

5c. PROGRAM ELEMENT NUMBER

5d. PROJECT NUMBER

NREL/TP-550-34832

5e. TASK NUMBER

BEC3.1001

5f. WORK UNIT NUMBER
7. PERFORMING ORGANIZATION NAME(S) AND ADDRESS(ES)

National Renewable Energy Laboratory

1617 Cole Blvd.

Golden, CO 80401-3393
8. PERFORMING ORGANIZATION REPORT NUMBER

NREL/TP-550-34832

9. SPONSORING/MONITORING AGENCY NAME(S) AND ADDRESS(ES)

10. SPONSOR/MONITOR'S ACRONYM(S) NREL

11. SPONSORING/MONITORING AGENCY REPORT NUMBER

\section{DISTRIBUTION AVAILABILITY STATEMENT}

National Technical Information Service

U.S. Department of Commerce

5285 Port Royal Road

Springfield, VA 22161

\section{SUPPLEMENTARY NOTES}

14. ABSTRACT (Maximum 200 Words)

Final report of energy performance analysis and design process evaluation for the Thermal Test Facility at the National Renewable Energy Laboratory.

15. SUBJECT TERMS

DOE; High Performance Buildings; energy analysis; energy performance analysis; design analysis; TTF; Thermal Test Facility

\begin{tabular}{|c|c|c|}
\hline 16. SECURIT & CLASSIFICATI & N OF: \\
\hline $\begin{array}{l}\text { a. REPORT } \\
\text { Unclassified }\end{array}$ & $\begin{array}{l}\text { b. ABSTRACT } \\
\text { Unclassified }\end{array}$ & $\begin{array}{l}\text { c. THIS PAGE } \\
\text { Unclassified }\end{array}$ \\
\hline
\end{tabular}

17. LIMITATION
OF ABSTRACT
UL

18. NUMBER
OF PAGES

19a. NAME OF RESPONSIBLE PERSON

19b. TELEPONE NUMBER (Include area code) 